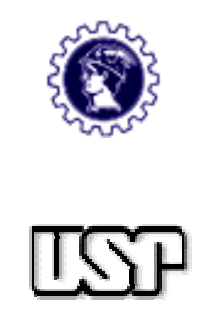

Universidade de São Paulo

Faculdade de Economia, Administração e Contabilidade

Programa de Pós-Graduação em Administração

\title{
Processo Decisório Estratégico na Empresa Industrial de Pequeno Porte (EIPP): Um estudo de caso
}

Estudo sobre a análise e escolha sob incerteza de alternativas estratégicas por sócios-gestores na pequena indústria no estado de São Paulo

\section{Sergio Gerletti}

Orientador: Prof. Dr. Antonio Cesar Amaru Maximiano

São Paulo, janeiro de 2009 
Profa. Dra. Suely Vilela

Reitora da Universidade de São Paulo

Prof. Dr. Carlos Roberto Azzoni

Diretor da Faculdade de Economia, Administração e Contabilidade

Prof. Dr. Isak Kruglianskas

Chefe do Departamento de Administração

Prof. Dr. Lindolfo Galvão de Albuquerque

Coordenador do Programa de Pós-Graduação em Administração 


\section{SERGIO GERLETTI}

gerletti@usp.br

\section{Processo Decisório Estratégico na Empresa Industrial de Pequeno Porte (EIPP): Um estudo de caso}

Estudo sobre a análise e escolha sob incerteza de alternativas estratégicas por sócios-gestores na pequena indústria no estado de São Paulo

Dissertação de Mestrado apresentada ao

Departamento de Administração da Faculdade de Economia, Administração e

Contabilidade da USP, como um dos requisitos para a obtenção do título de Mestre em Administração.

\section{Orientador: Prof. Dr. Antonio Cesar Amaru Maximiano}

\section{São Paulo}


Dissertação a ser defendida no departamento de Administração da Faculdade de Economia, Administração e Contabilidade da Universidade de São Paulo, pela seguinte banca examinadora:

Prof. Dr. Dr. Antonio Cesar Amaru Maximiano

Prof. Dr. Adelino de Bortoli Neto

Prof. Dr. Edson Ricardo Barbero

\section{FICHA CATALOGRÁFICA}

Elaborada pela Seção de Processamento Técnico do SBD/FEA/USP

Gerletti, Sergio

Processo decisório estratégico na empresa industrial de pequeno porte (EIPP): um estudo de caso / Sergio Gerletti. -- São Paulo, 2009. $182 \mathrm{p}$.

Dissertação (Mestrado) - Universidade de São Paulo, 2009 Bibliografia

1. Tomada de decisão (Administração executiva) 2. Administração estratégica 3. Estratégia organizacional 4. Pequenas e médias empresas I. Universidade de São Paulo. Faculdade de Economia, Administração e Contabilidade II. Título.

CDD -658.403 
Esta dissertação é dedicada a meus pais. 


\section{AGRADECIMENTOS}

O verdadeiro caminho para expressar a gratidão não é encontrado em nenhum outro lugar a não ser em nossa própria prática diária. Isto é, devemos praticar sem egoísmo e apreciar cada dia de nossas vidas. SUSHOGI

Ao Prof. Dr. Antonio Cesar Amaru Maximiano que, mesmo durante os momentos mais difíceis, foi orientador, apoiador e incentivador.

À Rosangela Vieira, sem cujo apoio e exemplo este estudo não teria sido realizad.

A todos os professores que contribuíram para a minha formação e que assim estão presentes neste trabalho. Em particular, aos professores do PPGA- FEA-USP, com especial gratidão àqueles cujas disciplinas tive o privilégio de cursar.

Aos amigos Daniel Pitelli de Britto, Edson Ricardo Barbero e Ricardo Pitelli de Britto, que me incentivaram e apoiaram de todas as formas e muito além dos limites usuais da amizade.

À amiga Marina Levy, pelo apoio incondicional e pela sua inesgotável alegria de viver.

À Valéria Trunkel Serrão, terapeuta e orientadora. E ao Dr. Luis Altenfelder e Dr. Walter Labonia, exemplos na prática da sua vocação.

Aos colaboradores do PPGA, em especial à Valéria.

À equipe da Praxian, pela colaboração e pelo incentivo.

Ao Prof. Adelino, Prof Roy e à equipe do projeto FIA-PROCED, em especial à Lucienee à Cris, pelas oportunidades, confiança e apoio.

Aos gestores das empresas que participaram do estudo de caso, pela inestimável colaboração.

Em especial, à minha família: meus pais, meu irmão, minhas sobrinhas e todos que, mesmo de longe, me apoiaram nesta empreitada. 
Dubium sapiantae initium.

(A dúvida é o início do conhecimento)

Provérbio latino 


\section{RESUMO}

Em situações de incerteza, o papel de tomador de decisões se apresenta como o mais relevante dentre os papéis do administrador. Os gestores, em especial de pequenas empresas, necessitam distinguir clara e imediatamente as questões estratégicas das menos relevantes. $\mathrm{O}$ foco do presente estudo é o processos decisório estratégico dos gestores das pequenas empresas industriais paulistas, expresso pela questão: Como os gestores das Empresas Industriais de Pequeno Porte (EIPPs) tomam decisões estratégicas?, sendo estas definidas aquelas de maior importância para a empresa (MINTZBERG et al, 1976) e abordadas como problemas de passagem - que apresentam várias possíveis soluções conforme proposto por Zaccarelli (2000). Diversos estudos (BORTOLI NETO, 1994; BERNHOEFT, 2001) têm indicado que, tipicamente, o sócio-gestor da pequena indústria estabelece com a empresa vínculos que transcendem os aspectos profissionais e econômicofinanceiros; em situações críticas, a influência dos aspectos emocionais e dos valores, crenças, experiência e intuição do gestor parecem preponderar, sendo provavelmente o papel da intuição nos processos decisórios um dos aspectos mais importantes e menos compreendidos no campo do estudo das decisões organizacionais. A partir do marco teórico do processo decisório em Administração e das principais caraterísticas de empresas industriais de pequeno porte (EIPP) e seus gestores, em particular na pequena indústria no estado de São Paulo, o presente estudo propõe um modelo teórico e aborda essa questão utilizando a técnica do estudo de caso, antecedido de uma análise de dados secundários de pesquisas recentes sobre EIPPs paulistas. Os resultados indicam que os gestores consideram que a racionalidade predomina nas suas decisões estratégicas e que estas são fortemente influenciadas por padrões do passado.

Palavras-chave: decisão estratégica, racionalidade, intuição, pequena indústria 


\section{ABSTRACT}

In uncertainty situations, the role of decision maker is the most important amongst the roles played by the administrator. The managers, specially in small companies, need to immediately distinguish clearly the strategical questions from ordinary ones. The focus of the present research is the study of the strategical decision processes of the managers of the small São Paulo industrial companies, expressed by the question: How do managers of the of Small Industrial Companies (EIPPs) make strategical decisions? , defined as those of most importance for the company (MINTZBERG et al, 1976) and approached as problems that present several possible solutions (ZACCARELLI, 2000). Several studies (BORTOLI NETO, 1994; BERNHOEFT, 2001) have indicated that, typically, the partner-manager of the small company establishes with the company bonds that exceed the professional and economic-financial aspects; in critical situations, the influence of emotional aspects and the values, beliefs, experience and intuition of the manager seem to preponde. The role of intuition in decision processes is probably one of the less understood and most important aspects in organizational decisions field of study. Starting from the theoretical landmark of decision process in Administration and the main carateristichs of small industrial companies (EIPP) and their managers, in particular the small industry in the state of São Paulo, in the present study a theoretical model is suggested and the research question is approached using the technique of case study, preceded by an analysis of secondary data from recent researches on EIPPS. The results indicate that the managers consider that the rationality predominates in their strategical decisions and that these are strongly influenced by standards from the past.

Key Words: strategical decision, rationality, intuition, small industry 


\section{Sumário}

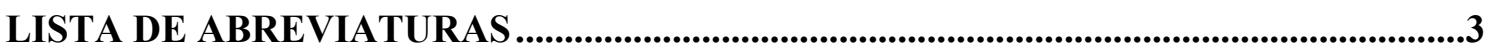

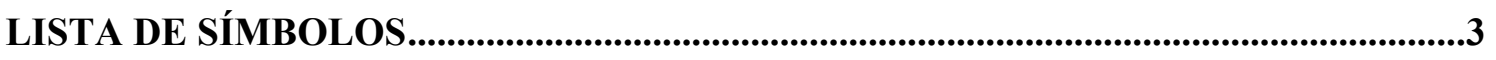

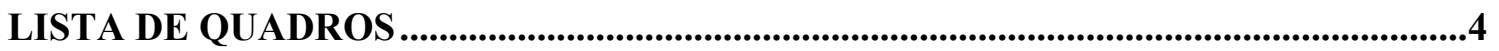

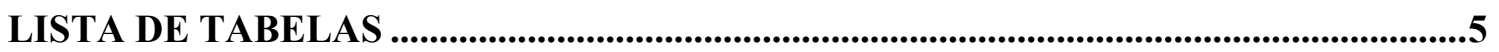

LISTA DE FIGURAS ........................................................................................................................6

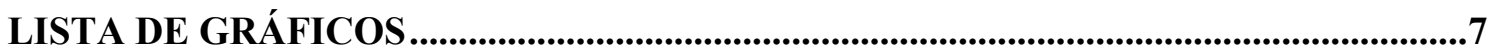

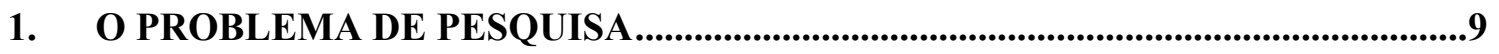

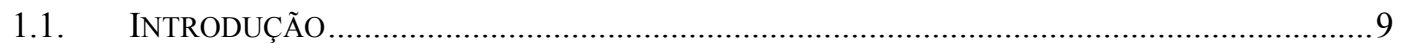

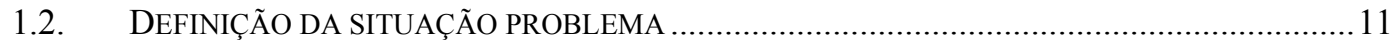

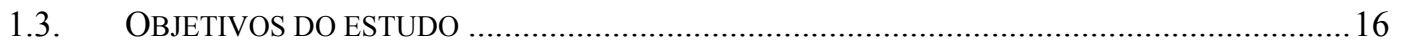

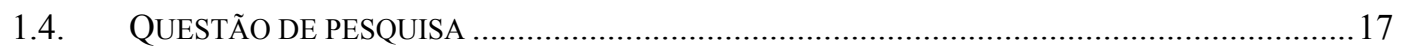

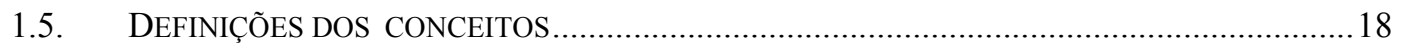

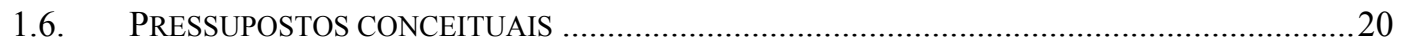

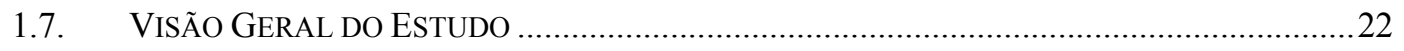

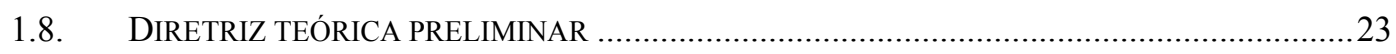

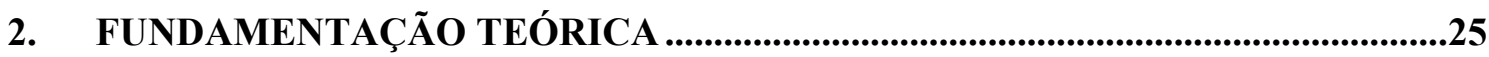

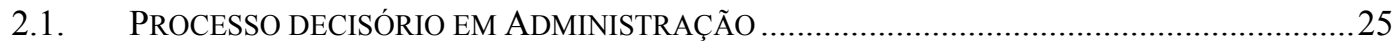

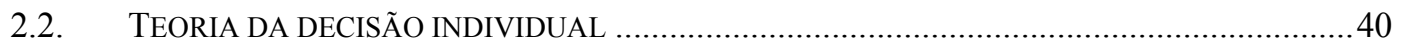

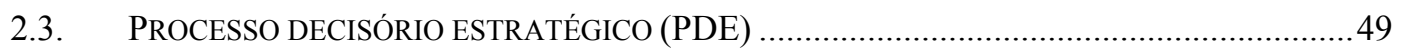

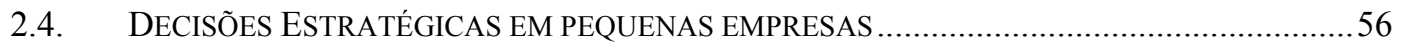

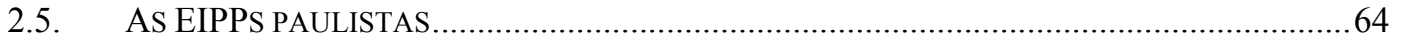

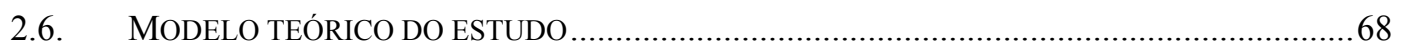




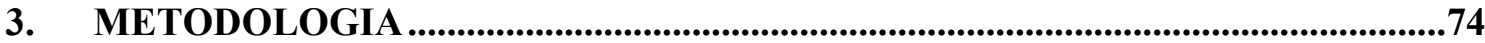

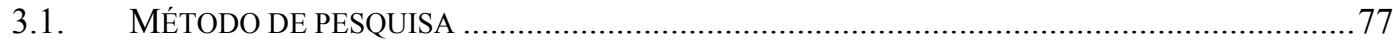

3.2. DEFINIÇÃO DO UNIVERSO E DAS ESTRATÉGIAS DO ESTUDO …........................................8

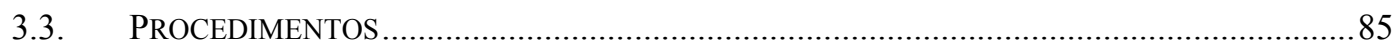

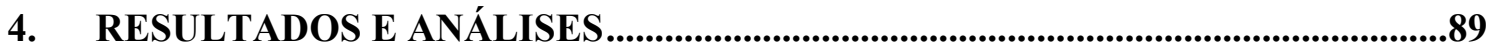

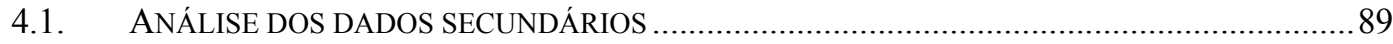

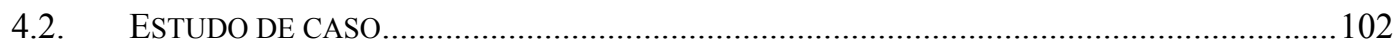

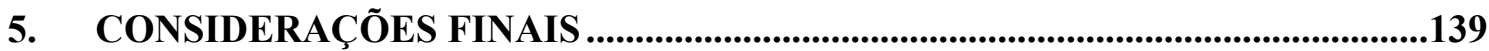

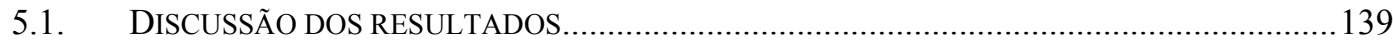

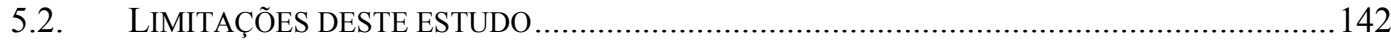

5.3. RECOMENDAÇÕES PARA ESTUDOS FUTUROS …............................................................ 144

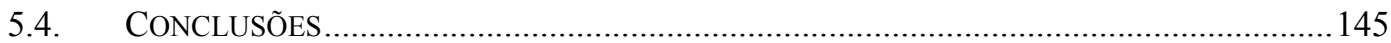

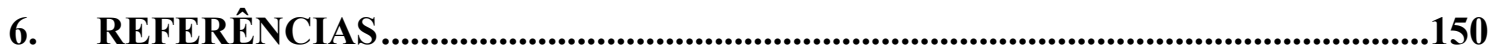

7. ANEXOS ..........................................................................................................................156

7.1. ANEXo 1: QUESTIONÁRIO DA PESQUISA SURVEY (BARBERO, 2008)..........................156

7.2. ANEXO 2: QUESTÕES DA PESQUiSA SURVEY (BRITTO, 2004, COM ADAPTAÇÕES); CARACTERÍSTICAS GERAIS E MATURIDADE ................................................................ 157

7.3. ANEXo 3: QUeSTÕES DA PESQUisa SURVEY (BRITTO, 2004, COM ADAPTAÇÕES);

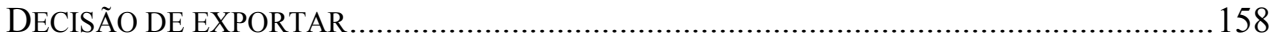

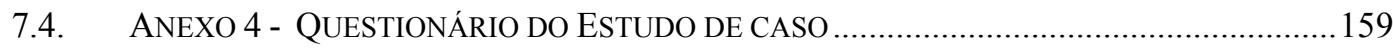

7.5. ANEXo 5 - MÉTOdo de AVAliaÇão PElo FluXo de CAIXA DeSCONTAdo .................160 
LISTA DE ABREVIATURAS

\begin{tabular}{|l|l|}
\hline BNDES & Banco Nacional de Desenvolvimento Econômico e Social \\
\hline CORE & Company Readiness to Export \\
\hline EIPP(s) & Empresa(s) industrial (is) de pequeno porte \\
\hline FIESP & Federação das Indústrias do estado de São Paulo \\
\hline IBGE & Instituto Brasileiro de Geografia e Estatística \\
\hline MIRA & Martinho Isnard Ribeiro de Almeida, nome do autor do método \\
\hline MPE(s) & Micro e pequena(s) empresa(s) \\
\hline OCDE & Organização para a Cooperação e Desenvolvimento Econômico \\
\hline PDE & Processo Decisório Estratégico \\
\hline PME(s) & Pequena(s) e média(s) empresa(s) \\
\hline SEBRAE & Serviço Brasileiro de Apoio às Micro e Pequenas Empresas \\
\hline SMART & Simple Multi-attribute Rating Technique \\
\hline
\end{tabular}

\section{LISTA DE SÍMBOLOS}




\section{LISTA DE QUADROS}

\begin{tabular}{|c|l|c|}
\hline Quadro & \multicolumn{1}{|c|}{ Título } & pg \\
\hline $\mathbf{1}$ & Definição das fronteiras e interesses do estudo através de perguntas e respostas & 23 \\
\hline $\mathbf{2}$ & Focos de Estudo da Decisão Organizacional & 30 \\
\hline $\mathbf{3}$ & Resumo dos vieses cognitivos & 44 \\
\hline $\mathbf{4}$ & Aspectos qualitativos característicos da pequena empresa & 58 \\
\hline $\mathbf{5}$ & Principais características de pequenas x grandes empresas & 59 \\
\hline $\mathbf{6}$ & Principais fatores de sucesso e erros mais comuns em pequenas empresas & 60 \\
\hline $\mathbf{7}$ & Estilos cognitivos segundo Kirton & 61 \\
\hline $\mathbf{8}$ & Categorias Estratégicas de Milles e Snow & 62 \\
\hline $\mathbf{9}$ & Enfoque quantitativo x Enfoque qualitativo & 78 \\
\hline $\mathbf{1 0}$ & Caracterização do estudo & 79 \\
\hline $\mathbf{1 1}$ & Perspectivas e aspectos de maturidade organizacional das EIPPs & 86 \\
\hline $\mathbf{1 2}$ & Medidas de maturidade das EIPPs e dos gestores & 92 \\
\hline $\mathbf{1 3}$ & Medidas de maturidade das EIPPs e dos gestores & 99 \\
\hline $\mathbf{1 4}$ & Escores (1) & 99 \\
\hline $\mathbf{1 5}$ & Escores (2) & 100 \\
\hline $\mathbf{1 6}$ & Resumo das respostas ao questionário (1) & 115 \\
\hline $\mathbf{1 7}$ & Resumo das respostas ao questionário (2) & 128 \\
\hline
\end{tabular}




\section{LISTA DE TABELAS}

\begin{tabular}{|c|l|c|}
\hline Tabela & \multicolumn{1}{|c|}{ Título } & pg \\
\hline $\mathbf{1}$ & Indústrias pesquisadas por ramo industrial & 78 \\
\hline $\mathbf{2}$ & Medidas de maturidade das EIPPs e dos gestores & 92 \\
\hline $\mathbf{4}$ & Escores (1) & 99 \\
\hline $\mathbf{5}$ & Escores (2) & 100 \\
\hline
\end{tabular}


LISTA DE FIGURAS

\begin{tabular}{|c|l|c|}
\hline Figura & \multicolumn{1}{|c|}{ Título } & pg \\
\hline $\mathbf{1}$ & Os papéis do administrador & 10 \\
\hline $\mathbf{2}$ & Situação-problema & 15 \\
\hline $\mathbf{3}$ & Diretriz Teórica Preliminar & 24 \\
\hline $\mathbf{4}$ & Fases e técnicas do processo estruturado de tomar decisões & 26 \\
\hline $\mathbf{5}$ & Decisão estratégica vista como problema de passagem & 27 \\
\hline $\mathbf{6}$ & Exemplo de diagrama de influências & 32 \\
\hline $\mathbf{7}$ & Exemplo de árvore de decisão & 32 \\
\hline $\mathbf{8}$ & Tela inicial do Método MIRA & 36 \\
\hline $\mathbf{9}$ & Processos intuitivos e Processos racionais & 42 \\
\hline $\mathbf{1 0}$ & Teoria dos Prospectos & 47 \\
\hline $\mathbf{1 1}$ & Modelo geral do processo decisório estratégico segundo Mintzberg et al & 52 \\
\hline $\mathbf{1 2}$ & As cinco dimensões da formação de estratégias segundo Barbero & 55 \\
\hline $\mathbf{1 3}$ & Diretriz Teórica ampliada & 70 \\
\hline $\mathbf{1 4}$ & Modelo Teórico do Estudo: Modelo tridimensional da decisão estratégica & 73 \\
\hline $\mathbf{1 5}$ & Roteiro Conceitual do Estudo & 85 \\
\hline $\mathbf{1 6}$ & Representação esquemática do PDE da BETA & 137 \\
\hline $\mathbf{1 7}$ & Representação esquemática do PDE da DELTA & 138 \\
\hline
\end{tabular}




\section{LISTA DE GRÁFICOS}

\begin{tabular}{|c|l|c|}
\hline Gráfico & \multicolumn{1}{|c|}{ Título } & pg \\
\hline $\mathbf{1}$ & $\begin{array}{l}\text { Respostas quanto ao grau de concordância à assertiva "O principal executivo determina } \\
\text { nossas estratégias" }\end{array}$ & 94 \\
\hline $\mathbf{2}$ & $\begin{array}{l}\text { Respostas quanto ao grau de concordância à assertiva "As estratégias tem de ser } \\
\text { alteradas porque algum grupo dificulta a implantação" }\end{array}$ & 95 \\
\hline $\mathbf{3}$ & $\begin{array}{l}\text { Respostas quanto ao grau de concordância às assertivas referentes a influências } \\
\text { cognitivas (racionalidade x intuição) }\end{array}$ & 96 \\
\hline $\mathbf{4}$ & $\begin{array}{l}\text { Respostas quanto ao grau de concordância às assertivas referentes a influências } \\
\text { ambientais (ambiente externo x interno) }\end{array}$ & 97 \\
\hline $\mathbf{5}$ & $\begin{array}{l}\text { Respostas quanto ao grau de concordância às assertivas referentes a influências } \\
\text { atitudinais (padrões do passado x visão de futuro) }\end{array}$ & 98 \\
\hline
\end{tabular}




\section{O PROBLEMA DE PESQUISA}

One kind of of optimism, or suposed optimism, argues that if we think hard enough and are rational enough, we can solve all our problems. The eighteenth century, the age of reason, was supposed to be imbued with this kind of optimism. Wether it was or not I will leave to historians; certainly the hopes we hold out for reason in our world today are much more modest.

Herbert Simon

\subsection{Introdução}

Em situações de turbulência e incerteza, tomar decisões pode ser a tarefa mais relevante e difícil do administrador. Nestas situações, os gestores necessitam distinguir clara e imediatamente as questões estratégicas - ou seja, as decisões realmente importantes daquelas corriqueiras e/ou pouco relevantes; e as decisões estratégicas deveriam consumir a maior parte da atenção, tempo e recursos destes gestores. Todavia, na pequena empresa freqüentemente a realidade é exatamente oposta: a maior parte do tempo do gestor é consumida em atividades corriqueiras, enquanto decisões importantes são adiadas e eventualmente tomadas sem que o decisor tenha plena consciência das suas implicações ou lhes tenha dedicado a atenção, tempo e esforço necessários para uma avaliação adequada: “Os problemas empresariais que afetam sobremaneira as PMEs são de natureza estratégica, 81,8\%, contra 18,8\% de recursos, [...] na Indústria, 90,0\% [...].” (BORTOLI NETO, 1980, grifo deste autor $\left.{ }^{1}\right)$.

Ao estudar as atribuições dos administradores (what managers do) a partir do conceito de papel (role) - definido como "um conjunto organizado de comportamentos, relativo a uma função (position), Mintzberg postula que a função fundamental do administrador é "colocarse entre a sua unidade (no caso do presidente ou sócio-gestor, a empresa) e seu ambiente". No

\footnotetext{
${ }^{1}$ Grifos tais como negrito ou itálico serão indicados no texto como "grifo no original" quando existentes no original citado; e como "grifo deste autor", referindo-se ao autor do presente estudo.
} 
desempenho desta tarefa fundamental, o autor classifica a atuação do administrador em dez papéis fundamentais, divididos em três grupos, conforme a figura abaixo:

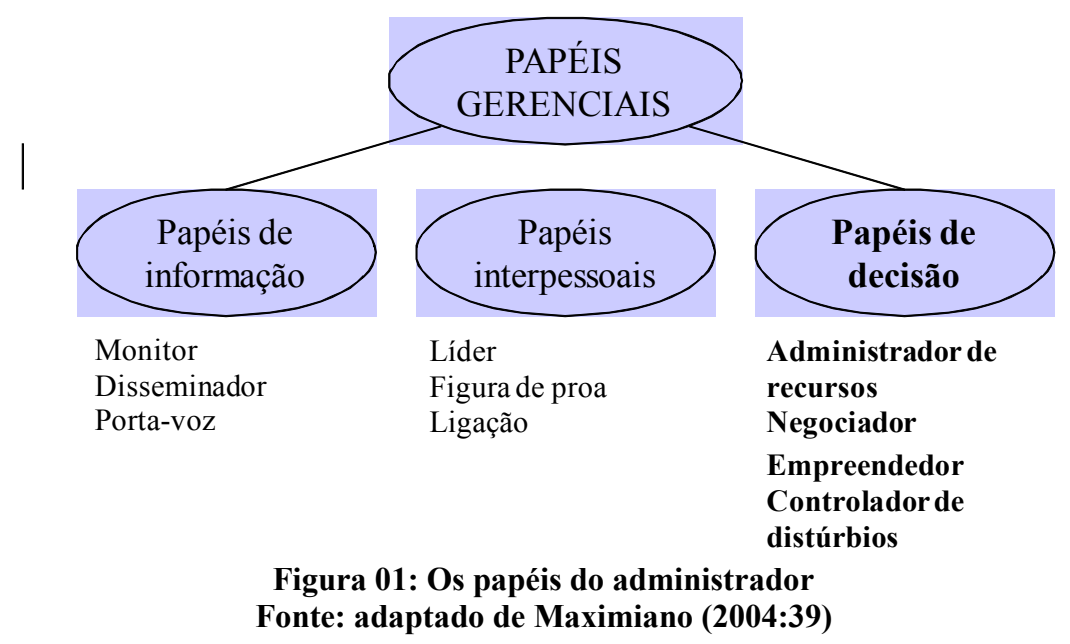

Mintzberg (1973) afirma ainda que o aspecto mais crucial do trabalho do administrador - e que justificaria em grande parte o seu poder, autoridade e acesso privilegiado à informação seja exatamente o de tomador de decisões, que "envolve o administrador no processo estratégico (strategy-making) da organização"; sendo este "simplesmente o processo pelo qual as decisões importantes são tomadas e inter-relacionadas." (MINTZBERG, 1973:77, grifo deste autor).

Também Morgan (1996) destaca a importância dos processos decisórios, ao analisar as organizações a partir da metáfora do "cérebro" - ou seja, vendo uma empresa como um conjunto de sistemas de análise de informações e tomada de decisões em um ambiente complexo. O autor assinala também outro aspecto - mais sombrio - dos processos decisórios, ao analisar a organização como uma "prisão psíquica" (ao modo da caverna de Platão) destacando que as pessoas são "prisioneiras da sua história de vida". Resultados de pesquisas sobre o desenvolvimento da psique humana indicam que a soma das experiências estabelecem padrões mentais dos quais raramente as pessoas têm plena consciência. $\mathrm{O}$ sócio- 
gestor da pequena empresa presumivelmente está sujeito às influências da "prisão psíquica", sem todavia contar com a relativa proteção oferecida pela estrutura organizacional e informacional - o "cérebro" - da grande empresa. E exerce - em geral, sozinho - as funções de identificar e analisar as diversas situações-problema, atribuir-lhes maior ou menor relevância e/ou urgência e finalmente escolher uma solução para cada uma - em suma, decidir, apesar das suas limitações e das dificuldades e riscos da tarefa. De que maneira isso ocorre e quais processos influenciam estas decisões são as indagações do presente estudo.

\subsection{Definição da situação problema}

Segundo Simon (1979), qualquer problema administrativo pode ser visto, em última análise, como uma decisão. Ao analisar os processos decisórios nas organizações, este autor estabelece a distinção entre decisões programadas - decisões de rotina, repetitivas e tomadas com base em dados suficientes - e não-programadas, que ocorrem em condições imprevisíveis, envolvem incerteza e portanto demandam o exercício da imaginação. Zaccarelli (2000) propõe um modelo de hieraquização destas decisões baseando-se na distinção entre problemas lógicos - com solução lógica e única - e problemas de passagem, que apresentam várias possíveis soluções. O autor salienta que estes últimos, quando referentes a questões relevantes para o futuro da empresa, configuram decisões estratégicas - que, a rigor, só podem ser avaliadas em função dos resultados que eventualmente produzam.

Em outras palavras, decisões constituem escolhas entre alternativas ou ainda, "um compromisso com um curso de ação específico" (MINTZBERG et al, 1976); quando nestas estão envolvidos diversos critérios conflitantes (por exemplo, potencial de redução de custo $\mathrm{x}$ impacto nas receitas) configuram-se problemas de passagem (ZACCARELLI, 2000). 
Finalmente, quando se apresenta um problema de passagem referente a uma questão fundamental para a continuidade e/ou desenvolvimento da empresa, o administrador se encontra diante de uma decisão estratégica (idem); uma escolha cujas conseqüências terão impacto profundo e duradouro sobre a empresa, sem que seja possível, no momento a escolha, identificar claramente as implicações de cada alternativa disponível. Em princípio, a decisão adequada é aquela que gera os efeitos mais positivos, contribuindo para que a organização atinja seus objetivos. Porém, como saber a priori se uma determinada decisão produzirá estes efeitos positivos? Nesta questão reside a importância do estudo do processo decisório - a busca de processos que melhorem as chances de produzir decisões adequadas.

Parece haver certo consenso, tanto entre os teóricos quanto entre os practioners da administração, quanto a relacionar decisões adequadas, em particular aquelas de caráter estratégico, a processos decisórios racionais - racionalidade esta geralmente entendida como o emprego de métodos analítico-quantitativos estruturados para garantir a qualidade das decisões. A história registra tanto desastres provocados por decisões baseadas em análises rigorosas - por exemplo, quando a Xerox abandonou o fax, baseando-se em resultados de pesquisas de mercado - quanto decisões de sucesso sem qualquer base analítica aparente, como o lançamento do walkman pela Sony no Japão empobrecido do pós-guerra; não obstante, parece razoável supor que na medida em que as decisões apresentam-se cada vez mais freqüentes e complexas, cresce a importância da análise sistemática dos fatores envolvidos. Por outro lado, o volume de informações relevantes torna a sua análise completa impraticável; este aparente paradoxo constitui um aspecto importante do presente estudo.

A este respeito, Morgan (1996) analisa a organização a partir de oito metáforas (máquina, organismo etc.) entre as quais a do "cérebro" (idem, capítulo 4); ou seja, a organização é vista 
como um sistema de processamento de informações. Este autor destaca que, diante do desafio da complexidade, em geral as organizações buscam reduzi-la - fragmentando, rotinizando e em última análise tolhendo o processo decisório. Em especial, este autor destaca a visão de Jay Galbraith, que “[...] identifica dois planejamentos estratégicos para lidar com a incerteza. O primeiro envolve procedimentos para reduzir a necessidade de informações [...]. O segundo envolve crescente capacidade de lidar com a informação [...]”. (MORGAN, 1996). Em outras palavras, estabelece-se uma "hierarquia", na qual a complexidade das decisões corriqueiras é reduzida por meio da adoção de certos padrões, que estabelecem as linhas gerais de conduta da organização; as decisões estratégicas se referem ao estabelecimento destes padrões.

Por outro lado, estudos de diversos autores - tais como Simon, Kahnemann, Tversky e Bazerman, para citar apenas alguns entre os mais proeminentes - indicam que nos processos decisórios, em particular nas situações mais críticas, a consideração analítica e racional dos fatores explicitamente conhecidos pelo decisor parece desempenhar papel relevante, todavia definitivamente limitado. Processos não analíticos parecem predominar principalmente em situações de crise; nestes momentos, entram em jogo a emoção, as crenças, a experiência. Em algumas situações, o conjunto destes fatores recebe o nome de intuição; o papel dos processos intuitivos provavelmente constitua um dos aspectos mais importantes e menos compreendidos no campo do estudo das decisões organizacionais. Em situações nas quais a decisão é tomada individualmente, sob pressão e sem que o decisor conte com uma estrutura formal de apoio à tomada de decisões - como geralmente é o caso quando se trata do gestor de uma pequena empresa, foco do presente estudo- é muito provável que as decisões intuitivas constituam a regra, sendo portanto relevante o seu estudo. 
A importância de se estudar os aspectos particulares dos processos decisórios de empresas industriais de pequeno porte (EIPPs) está ligada à crescente importância destas últimas no moderno ambiente de negócios. Após várias décadas de predominância da grande indústria como paradigma de organização - ao lado das estruturas de governo e dos conglomerados financeiros - na chamada "nova economia", com as suas crescentes exigências de agilidade e flexibilidade, tem-se visto crescer a importância da pequena empresa industrial.

Cumpre ainda considerar a importância das pequenas empresas, em particular as indústrias (EIPPs) brasileiras (em particular, as paulistas), que respondem por parcelas expressivas do PIB, do emprego e e da renda. Pesquisas do SEBRAE (2008) indicam que no Brasil existem 5,1 milhões de empresas, sendo que deste total, 98\% são micro e pequenas empresas (MPEs), que respondem por mais de dois terços das ocupações do setor privado. No estado de São Paulo existem 1,3 milhões de MPEs, sendo que 43\% atuam no comércio, 31\% em serviços, 14\% na agropecuária e $12 \%$, na indústria, levando a uma estimativa de 156.000 MPEs industriais no estado de São Paulo. Dados da FIESP, reportados por Britto (2004), indicam que do universo de 16.384 da empresas industriais paulistas associadas à FIESP em 2002, cerca de 11.000 - quase $70 \%$ - poderiam ser consideradas de pequeno porte.

Finalmente, pesquisa elaborada pelo SEBRAE (2004) sobre a sobrevivência das empresas de pequeno porte aponta que $60 \%$ das empresas brasileiras encerram suas atividades nos primeiros cinco anos. Isto representa o dobro da proporção identificada entre países membros da Organização para a Cooperação e Desenvolvimento Econômico (OCDE), sendo as perdas estimadas em "530 mil ocupações e de R\$ 15,6 bilhões por ano", apenas no estado de São Paulo; cerca de $9 \%$ destas perdas ocorrem no setor industrial. A mesma pesquisa indicou como os principais fatores determinantes da mortalidade de empresas as deficiências no 
planejamento antes da abertura do negócio e na gestão empresarial - que responderia por cerca da metade dos fracassos. Estes dados indicam uma possibilidade de economias na ordem de R $\$ 100 \mathrm{M} /$ ano para cada ponto percentual de redução da mortalidade das EIPPs paulistas, cuja causa principal são as falhas de planejamento - em última análise, decisões equivocadas. Como se verá adiante, estas empresas geralmente são dirigidas pelos seus proprietários, responsáveis pelas decisões das quais dependem a sobrevivência e o crescimento destas empresas; assim sendo, o processo decisório dos sócios-gestores das pequenas empresas industriais (EIPPs) paulistas constitui um objeto de estudo relevante.

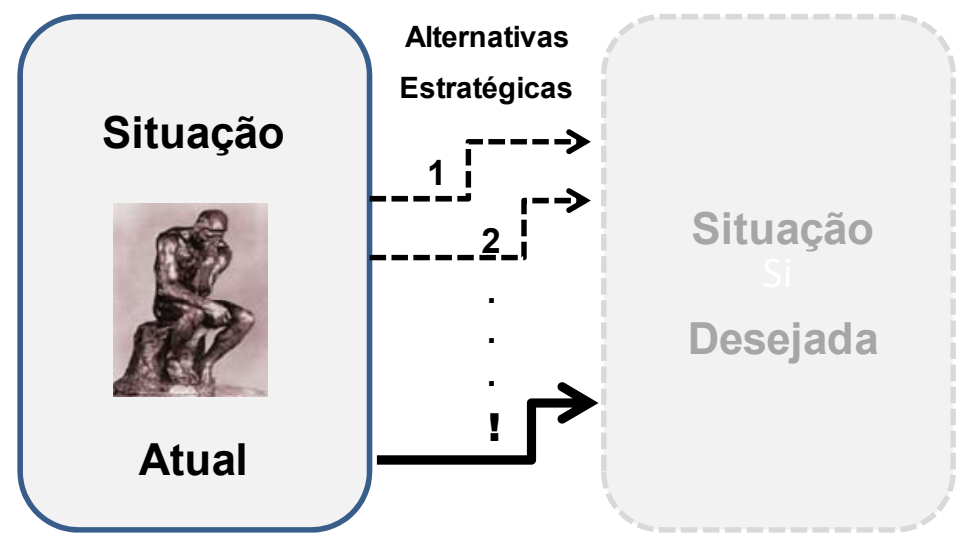

Figura 02: Situação-problema Fonte: adaptado pelo autor de Zaccarelli (2000:60)

Feitas estas considerações, a figura acima ilustra a situação-problema abordada no presente estudo. Este tem por objetivo analisar um tipo de situação na qual o sócio-gestor de uma empresa industrial de pequeno porte (i) encontra-se diante de uma situação-problema (ou seja, vislumbra uma situação futura possível mais desejável do que a atual, ou melhor, do que a evolução "natural" da situação atual); (ii) percebe que o encaminhamento desta situação deverá ter grande influência sobre o futuro da empresa (decisão estratégica); (iii) identifica duas ou mais linhas de ação (alternativas estratégicas) que aparentemente podem conduzir ao resultado desejado; (iv) não tem meios de identificar a priori qual destas alternativas seria "a 
melhor" (inclusive porque não tem plena consciência das suas preferências). Este decisor tem acesso limitado a técnicas de apoio à decisão (seja por falta de conhecimento e/ou recursos); e deve decidir sozinho, ou seja, mesmo que possa ou até precise consultar outras pessoas (um sócio, por exemplo), a escolha final deve ser feita por um indivíduo, que tem consciência que os resultados desta escolha terão grande influência no seu futuro profissional e pessoal.

\subsection{Objetivos do estudo}

Dadas as considerações acima, a presente pesquisa tem por objetivo verificar como e porque os sócios-gestores realizam o processo decisório dentro de uma pequena indústria (EIPPs), especificamente ao escolherem entre diversas alternativas estratégicas. Como e porque se referem respectivamente ao método - de que forma e utilizando quais instrumentos - e à motivação - por quais razões e com que objetivos - estes gestores tomam decisões (fazem determinadas escolhas) estratégicas. $\mathrm{O}$ autor do presente estudo espera contribuir para uma melhor compreensão deste processo e possivelmente para o seu aprimoramento.

Estudos têm indicado que, tipicamente, o sócio-gestor da pequena indústria estabelece com a empresa (na grande maioria dos casos, de base familiar, situação na qual cresce a influência das questões emocionais) vínculos que ultrapassam os aspectos profissionais e econômicofinanceiros (BORTOLI NETO, 1994; BERNHOEFT, 2001). Bernhoeft, por exemplo, afirma que o empreendedor vê a empresa como "um filho que ele gerou sozinho" e com "quem" mantém um relacionamento altamente emocional, freqüentemente mais intenso do que com os familiares, em especial os filhos - que freqüentemente acabam "odiando" a empresa, na qual eventualmente vêm a atuar. A presença destas dinâmicas, analisadas extensamente por Lourenzo (2006), embora não constitua o foco do presente estudo, reforça a premissa de que 
nas grandes decisões dos gestores destas empresas, dificilmente os processos analíticos e os aspectos racionais serão preponderantes.

Principalmente quando se apresentam situações críticas, entram em jogo aspectos emocionais, valores, crenças, experiência, que, combinados, parecem dar origem ao processo conhecido como intuição. Não obstante a complexidade do tema - considerado de fronteira mesmo entre especialistas do campo da psicologia social - um dos objetivos desta pesquisa é estudar o papel da intuição nos processos decisórios. O autor do presente estudo considera que, provavelmente, os processos decisórios estratégicos dos gestores de EIPPs - envolvendo decisões de longo alcance, dificilmente reversíveis e com forte impacto sobre o futuro da empresa - sejam predominantemente intuitivos, e que seja possível melhorar a sua qualidade e consistência a partir de uma melhor compreensão destes processos.

\subsection{Questão de pesquisa}

A partir das considerações acima, o foco do presente estudoé o processos decisório estratégico dos gestores das pequenas empresas, expresso pela questão:

\section{Como os sócios-gestores das EIPPs tomam decisões estratégicas?}

Dada sua amplitude, esta questão pode ser assim subdividida:

- Como os sócios-gestores das EIPPs identificam questões estratégicas - em termos de situação inicial e situação desejada - e como geram alternativas estratégicas?

- Quais fatores os gestores das EIPPs consideram para (a) definir os critérios de escolha, (b) confrontar os fatores e critérios conflitantes (trade-offs) e finalmente (c) escolher a alternativa estratégica a ser implementada?

- Quais são os principais fatores a influenciar o processo decisório?

- Qual o papel e a importância relativa dos processos racionais e intuitivos na escolha de alternativas estratégicas? 


\subsection{Definições dos conceitos}

Enquanto me exprimi em termos curtos, não me compreendias nem sabias interpretar minhas respostas... Sócrates, nas Górgias de Platão

A clara definição dos termos empregados constitui um aspecto fundamental do trabalho do pesquisador (SANTOS, 2008), especialmente quando o estudo se refere a conceitos cujo sentido não se encontra claramente estabelecido ou é objeto de debates, como é o caso do tema do presente estudo. Assim sendo, neste item são apresentadas as definiç̧ões dos principais conceitos analisados, de acordo com os autores que representam as referências adotadas por este autor. Cumpre ressaltar que outros autores podem adotar para esses conceitos e termos significados e acepções bastante diferentes dos aqui adotados. Optou-se por apresentar aqui apenas as definições dos conceitos discutidos no referencial teórico. (Nota: As definições operacionais, que se referem à construção das variáveis analisadas no item 4.1, são apresentadas no item 3.3.)

Decisão se refere ao ato de optar por uma entre várias possibilidades de ação, ou seja, escolher uma solução para um problema que apresenta várias alternativas, que devem ser confrontadas em relação a um conjunto de critérios, que expressam as preferências do decisor (BAZERMAN, 2004). Em outras palavras, a decisão constitui "um compromisso específico com a ação" (MINTZBERG et al, 1976), enquanto processo decisório se refere a "um conjunto de ações e fatores" que começa na identificação da situação-problema, passa pela geração e análise de alternativas e termina com uma escolha - a decisão (idem).

Quando é possível identificar uma alternativa dominante (que resulta em uma solução superior em todos os critérios), trata-se de um problema lógico, com solução definida 
(ZACCARELLI, 2000). Entretanto, na realidade das organizações, geralmente os problemas se apresentam de forma que cada alternativa mostra-se mais atraente em relação a certos critérios e menos em outros, ficando assim configurado um problema de passagem (idem), que exige do decisor uma escolha baseada em avaliações de preferências e valores. Quando se apresenta um problema de passagem cujo encaminhamento é dificilmente reversível e terá influência relevante e duradoura sobre a organização, trata-se de um problema estratégico, cujas possíveis soluções constituem alternativas estratégicas; o método empregado para sua avaliação constitui o processo decisório estratégico e a escolha da alternativa preferida pelo decisor, a decisão estratégica. (ibidem).

Cabe destacar a questão da consciência do decisor quanto ao caráter da decisão analisada; no presente estudo, adota-se como pressuposto que, ao tomar uma decisão estratégica, o decisor tem plena consciência da sua importância, irreversibilidade e potencial impacto sobre a organização; admite-se também que durante o processo decisório estratégico o tomador de decisões utiliza uma combinação de racionalidade e intuição. (KAHNEMANN, 2003).

Racionalidade indica uma escolha deliberada, guiada pelas expectativas do tomador da decisão sobre as suas conseqüências em relação a um conjunto de valores (critérios), que por sua vez orienta as suas preferências. Refere-se, portanto, ao processo de identificação da alternativa que supostamente conduz ao resultado ótimo, definido como aquele que proporciona o maior valor esperado e geralmente envolvendo a análise quantitativa das alternativas disponíveis. (idem).

Intuição indica processos espontâneos, imediatos e geralmente livres de esforço mental perceptível e que respondem pela maior parte das atividades diárias (ibidem). O emprego de 
processos intuitivos em situações complexas está relacionado ao desvio da racionalidade, que pode manifestar-se tanto na forma de erros óbvios quanto em desempenhos excepcionais, sendo estes em geral relacionados a fatores como experiência profissional, preparo intelectual ou outras características do decisor. (BAZERMAN, 2004)

A presente pesquisa analisa apenas decisões individuais, ou seja, parte-se do pressuposto que, em última instância, a decisão estratégica é tomada por uma pessoa, diretamente responsável pelas suas conseqüências e pessoalmente atingida por elas. Em outras palavras, neste estudo os efeitos da estrutura organizacional e das decisões em grupo (SIMON, 1979) e os aspectos do poder e política nas organizações (BARBERO, 2008) não são considerados, o que parece ser coerente com a realidade do típico sócio-gestor da empresa de pequeno porte.

Em especial, o presente estudo aborda a empresa industrial de pequeno porte (EIPP) uma empresa com 10 a 50 colaboradores $^{2}$ (FIESP, 2002, apud BRITTO, 2004) - que atua predominantemente em atividade de transformação. Nesta pesquisa serão estudadas EIPPs associadas à FIESP, atuantes em setores industriais tradicionais até R\$20.000.000 e administradas por sócios-gestores, ou seja, nas quais as funções diretivas são exercidas por sócios da empresa. Estes constituem a principal unidade de análise do presente estudo; cabe observar que o gênero masculino (gestor, sócio-gestor etc.) é adotado por apenas por praticidade, ou seja, leia-se gestor e sócio-gestor como gestor (a) e sócio (a)-gestor (a).

\subsection{Pressupostos conceituais}

Uma vez estabelecidas as definições dos principais termos que serão utilizados neste estudo, vale ressaltar que a presente pesquisa tem como objetivo estudar o processo decisório

\footnotetext{
${ }^{2}$ Empresas industriais com até 10 colaboradores são consideradas micro-empresas.
} 
estratégico na empresa industrial de pequeno porte (EIPP). Para tanto, é conveniente estabelecer um conjunto de pressupostos conceituais; premissas que emergem da discussão desenvolvida até este ponto. Tais premissas constituem o embasamento conceitual do estudo e são, portanto adotadas, não sendo a sua discussão objeto do presente estudo.

i. As decisões organizacionais se apresentam de formas diversas quanto à sua importância, urgência e complexidade.

ii. De acordo com estas características, as decisões provavelmente se distribuem ao longo de um continuum entre os extremos da racionalidade e da intuição "puras";

iii. Geralmente o processo decisório envolve a combinação de racionalidade e intuição muito raramente devem ocorrer decisões "puramente" racionais ou intuitivas;

iv. O foco do estudo está nas decisões estratégicas - de grande impacto sobre a empresa e dificilmente reversíveis, sendo que o decisor tem consciência da influência da sua decisão sobre o futuro e até a sobrevivência da empresa;

v. O objeto do estudo é o processo decisório estratégico, ou seja, como e por que as decisões são tomadas, independente do seu conteúdo e/ou eventuais resultados;

vi. Na organização estudada, as decisões são individuais - em última análise, uma única pessoa toma a decisão e se encarrega de implementá-la;

vii. Este decisor busca a racionalidade - maximização do valor do resultado independente do método (ou "não-método) utilizado. A maior ou menor importância atribuída pelo decisor respectivamente à análise racional e à intuição depende fundamentalmente de suas características pessoais;

viii. Em geral, em que pese o estilo pessoal dos gestores, as decisões são fortemente condicionadas pelas restrições impostas pelo ambiente.

Em suma, a presente pesquisa focalizará o processo decisório estratégico na EIPP - empresa que exerce atividade de transformação em setor estabilizado e relativamente pouco sujeito a turbulências (empresas baseadas nas chamadas "novas tecnologias", que atuam em setores de alta complexidade e turbulência tecnológica são explicitamente exclusas); tem de 10 a 50 colaboradores e faturamento anual na ordem de $\mathrm{R} \$ 2.000 .000$ a 20.000.000. Baseando-se em estudos anteriores (BORTOLI NETO, 2003; SEBRAE, 2004) o autor do presente estudo 
assume que, tipicamente, estas empresas são administradas por sócios-gestores, que dependem financeiramente dos resultados da empresa; estes têm com a empresa fortes vínculos pessoais e emocionais, seja por questões de realização pessoal, seja de vínculos familiares e/ou afetivos e são integralmente responsáveis pelo processo decisório estratégico na empresa, tendo autoridade para tomar decisões e responsabilidade pelos resultados.

Estas premissas fornecem as bases para a identificação e discussão dos elementos levantados na pesquisa do referencial teórico, bem como para a análise de dados secundários de pesquisas recentes sobre a indústria paulista (BRITTO, 2004; BARBERO, 2008). A discussão destes elementos deverá fornecer suporte para o estudo de caso - decisão estratégica tomada por sócio-gestor de EIPP - que constitui o núcleo desta pesquisa.

\subsection{Visão Geral do Estudo}

Este tópico tem como objetivo apresentar os elementos deste estudo sobre processo decisório estratégico em empresas industriais de pequeno porte (EIPPs). Este primeiro capítulo introduz, contextualiza e delimita o tema, detalhando o problema da pesquisa e seus objetivos. O Capítulo 2 traz a revisão do referencial teórico, abordando o marco teórico do processo decisório em Administração; a teoria da decisão e dos modelos de apoio a decisões em condições de incerteza, (múltiplos objetivos e critérios e papel da intuição), com ênfase nas decisões estratégicas, em particular em pequenas empresas, concluindo com as principais características de pequenas empresas industriais (EIPP) e seus gestores, incluindo um panorama da pequena indústria no estado de São Paulo.

O Capítulo 3 aborda as metodologias utilizadas na pesquisa, apresentando os fundamentos do método de estudo de casos e prosseguindo com a descrição da metodologia aplicada na 
presente pesquisa, em especial na sua fase de campo. O capítulo 4 traz os resultados da etapa de campo do estudo, dividida em análise de dados secundários e estudo de caso, estruturado a partir de um caso principal - uma decisão estratégica em uma EIPP, estudada em profundidade - e um caso de apoio. Finalmente, o capítulo 5 traz as considerações finais do autor acerca dos limites e conclusões do estudo, bem como recomendações para estudos futuros. Em suma, o estudo analisa o processo de escolha entre alternativas estratégicas por sócios-gestores da EIPP; o quadro a seguir representa o modelo conceitual do estudo, a ser detalhado no Capítulo 3.

Quadro 01 - Definição das fronteiras e interesses do estudo através de perguntas e respostas

\begin{tabular}{|l|l|}
\hline Pergunta & \multicolumn{1}{|c|}{ Resposta } \\
\hline O que? & $\begin{array}{l}\text { O presente estudo analisará o processo de escolha de alternativas estratégicas por sócios- } \\
\text { gestores da empresa industrial de pequeno porte (EIPP) paulista. }\end{array}$ \\
\hline Onde? & O estudo será realizado em empresas industriais de pequeno porte do estado de São Paulo. \\
\hline Como? & $\begin{array}{l}\text { Será utilizada a abordagem exploratória com o intuito de propor generalizações analíticas a } \\
\text { partir da análise de (a) dados secundários levantados em pesquisas anteriores sobre empresas } \\
\text { industriais no estado de São Paulo e (b) um estudo de caso }\end{array}$ \\
\hline Por quê? & $\begin{array}{l}\text { A teoria sobre processos decisórios se mostra fragmentada em função de uma divisão histórica } \\
\text { entre abordagens prescritivas e descritivas. Adicionalmente, os estudos sobre os gestores de } \\
\text { pequenas empresas industriais são escassos, ao passo que a importância destas tem aumentado. } \\
\text { Assim, justifica-se um estudo que contribua para preencher tais lacunas, principalmente } \\
\text { considerando que à medida que os ambientes de negócios vão se tornando cada vez mais } \\
\text { dinâmicos e complexos, cresce a importância dos processos decisórios. }\end{array}$ \\
\hline
\end{tabular}

Fonte: adaptado a partir de BARBERO (2008:17)

\subsection{Diretriz teórica preliminar}

O foco do presente estudoé o estudo do processo decisório estratégico em EIPPs; em outras palavras, deseja-se estudar como e por que o sócio-gestor da pequena indústria escolhe uma (entre várias possíveis) alternativa estratégica - entendida como um conjunto de ações, em geral consubstanciadas em um projeto ou programa - buscando conduzir a empresa da sua situação atual para uma situação desejada. Esta questão inclui a análise dos fatores que 
influenciam esta escolha (decisão) - ou seja, por que o decisor considera um determinado conjunto de fatores, atribuindo-lhes certos pesos relativos - de forma mais ou menos consciente e deliberada. A figura a seguir resume estas considerações:

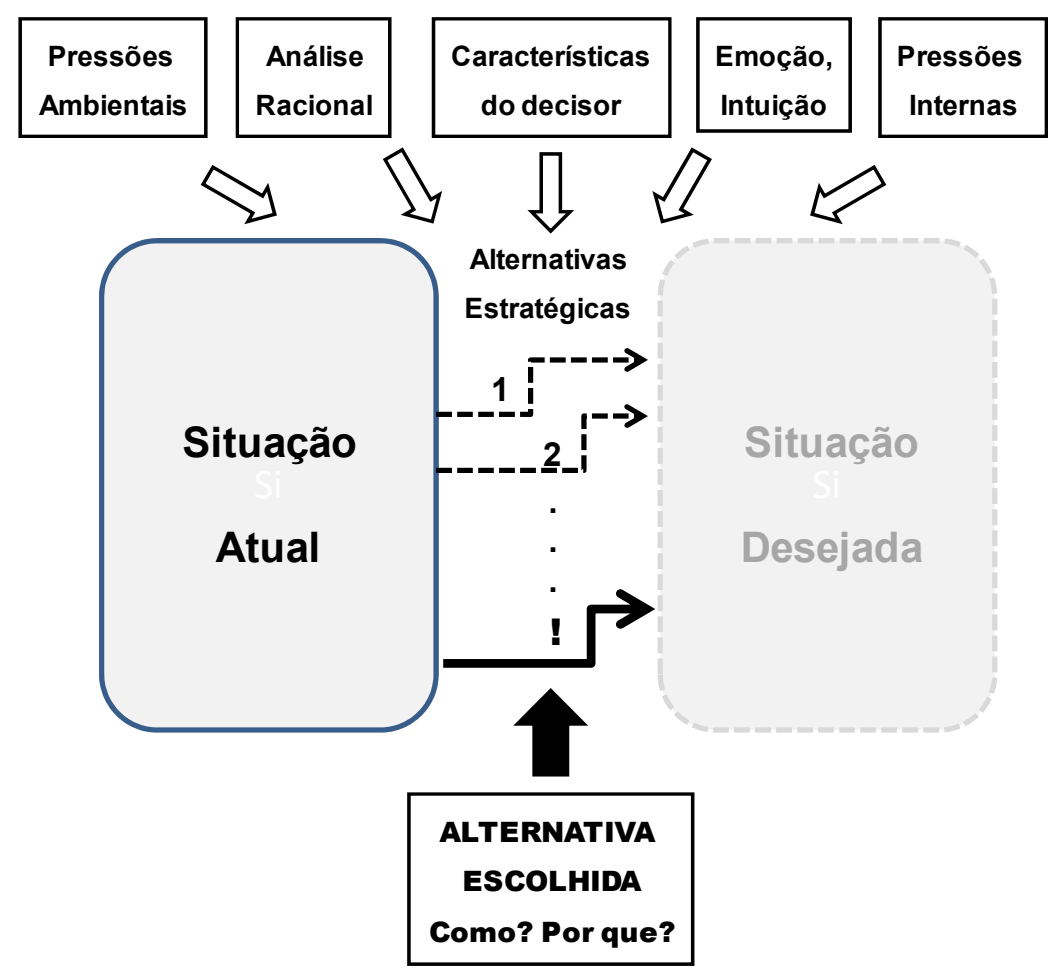

Figura03: Diretriz Teórica Preliminar Fonte: elaborada pelo autor

A diretriz teórica sintetizada acima contém os elementos iniciais do modelo teórico do estudo, a ser construído a partir da revisão do referencial teórico, que constitui o objeto do próximo capítulo. 


\section{FUNDAMENTAÇÃO TEÓRICA}

As coisas não têm explicação, têm existência.

Fernando Pessoa

O presente estudo analisa o processo decisório estratégico em empresas industriais de pequeno porte (EIPPs); em outras palavras, deseja-se estudar o processo (como e por que) de escolha entre alternativas estratégicas por sócios-gestores da EIPP. Na busca deste objetivo, o presente capítulo apresenta uma visão geral do campo de estudo das decisões organizacionais, buscando confrontar e integrar abordagens teóricas bastante diversas; buscase estabelecer inicialmente os conceitos mais gerais do processo decisório, prosseguindo então para a discussão para aspectos mais específicos referentes às decisões estratégicas, em particular no âmbito da pequena empresa industrial.

No item 2.1 são apresentados os fundamentos do processo decisório em Administração, com ênfase na divisão histórica deste campo de estudos em abordagens normativas e descritivas. Esta divisão é mais bem explorada no item 2.2, no qual são discutidos aspectos teóricos da decisão individual, seguido por uma discussão mais específica sobre decisões estratégicas (item 2.3), em particular no contexto da pequena empresa (2.4). A seção se conclui com uma análise das principais características das EIPPs paulistas (item 2.5), seguida da apresentação da diretriz teórica do estudo, que estabelece a conexão entre o presente capítulo e o seguinte, no qual são apresentados os métodos empregados na fase de campo do estudo.

\subsection{Processo decisório em Administração}

Tomar decisões significa fundamentalmente identificar uma entre várias alternativas de solução para um problema. Segundo Bazerman (2004), o processo racional de tomada de decisão deve seguir etapas bem determinadas: (1) definir o problema, (2) identificar os 
critérios, (3) ponderar os critérios, (4) gerar alternativas, (5) classificar cada alternativa segundo cada critério e (6) identificar a solução ótima. Para que uma decisão seja considerada racional, pressupõe-se que o tomador da decisão (1) define corretamente o problema, (2) identifica todos os critérios, (3) pondera adequadamente todos os critérios, (4) conhece todas as alternativas, (5) avalia acuradamente cada alternativa, (6) calcula um valor preciso para cada alternativa - baseado na ponderação dos critérios - e escolhe a alternativa de maior valor percebido. Embora existam diversas variantes de metodologias de análise de decisão, como por exemplo, a proposta por Maximiano, ilustrada na figura a seguir, de forma geral estas não diferem fundamentalmente da proposta acima.

\begin{tabular}{|c|c|c|}
\hline PERGUNTAS & ETAPAS & TÉCNICAS \\
\hline $\begin{array}{l}\text { - Como implementar a } \\
\text { escolha? } \\
\text { - Qual alternativa é melhor? } \\
\text { - Quais suas vantagens e } \\
\text { desvantagens? } \\
\text { - Quais as alternativas }\end{array}$ & ALTERNATIVAS & $\begin{array}{l}\text {-Explicitação e ponderação } \\
\text { de critérios } \\
\text { - Análise do campo de forças } \\
\text { - Análise de vantagens / } \\
\text { desvantagens } \\
\text { - Árvore de decisões }\end{array}$ \\
\hline $\begin{array}{l}\text {-Quais os objetivos da } \\
\text { decisão? } \\
\text { - Quais as prioridades? } \\
\text { - Qual o problema ou } \\
\text { oportunidade? }\end{array}$ & $\begin{array}{c}\text { PROBLEMAOU } \\
\text { OPORTUNIDADE }\end{array}$ & $\begin{array}{l}\text { - Paradigma de Rubinstein } \\
\text { - Diagrama de Ishikawa } \\
\text { - Análise de urgência e } \\
\text { importância } \\
\text { - Princípio de Pareto }\end{array}$ \\
\hline
\end{tabular}

Figura 04: Fases e técnicas do processo estruturado de tomar decisões Fonte: Maximiano (2000:158)

Cabe aqui estabelecer uma distinção fundamental entre problemas lógicos - que podem ser resolvidos com a adoção de uma alternativa dominante nitidamente superior a qualquer outra (ZACCARELLI, 2000), configurando uma decisão sob certeza (TURBAN; MEREDITH, 1994, apud DACORSO, 2000), - e problemas de passagem, que apresentam 
várias soluções possíveis. Estabelecendo um paralelo com problemas algébricos representados por sistemas de $n$ equações a $m$ incógnitas, um problema lógico corresponde à situação na qual $n=m$, ou seja, o número de equações corresponde ao de incógnitas e o sistema é determinado, ou seja, apresenta solução única. Já um problema de passagem, corresponde a um sistema no qual $n<m$, ou seja, o número de incógnitas supera o de equações, configurando um sistema indeterminado, compatível com diversas soluções. As decisões estratégicas sempre se referem de um problema de passagem, cabendo ao decisorestrategista escolher uma solução entre várias possíveis, (ZACCARELLI, 2000), conforme esquematizado na figura abaixo.

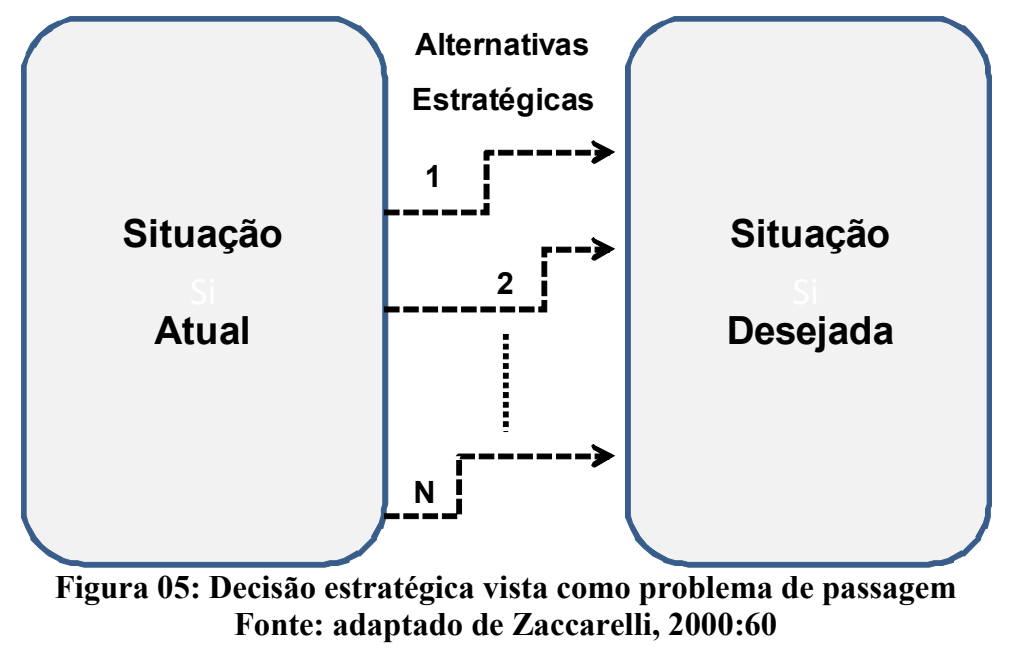

Um aspecto fundamental deste tipo decisão é a presença de risco e incerteza. Segundo Turban e Meredith (1994, apud DACORSO, 2000), ocorre uma decisão sob risco (também chamada probabilística ou estocástica) quando o decisor tem meios de avaliar as probabilidades de ocorrência de cada resultado possível de cada alternativa considerada. Quando o decisor não tem elementos para estimar estas probabilidades, trata-se de uma decisão sob incerteza, o caso típico das decisões estratégicas abordadas neste estudo. 
A distinção entre risco e incerteza é um conceito enfatizado por Knight (1921, apud

BERNSTEIN, 1997), que destacou a impossibilidade prática de aplicar métodos estatísticos

(ou seja, a extrapolação de séries passadas para previsão do futuro) às situações do mundo

dos negócios, no qual “[...] a incerteza tende mais a prevalecer do que a probabilidade matemática":

A incerteza deve ser tomada em um sentido radicalmente distinto da noção familiar de risco, da qual nunca foi adequadamente separada [...] Descobrir-se-á que uma incerteza mensurável, ou "risco" propriamente [...] é tão diferente de uma imensurável que, na verdade, não chega a ser uma incerteza (KNIGHT, 1921, apud BERNSTEIN, 1997:219, itálicos no original)

Qualquer "ocorrência" [...] é tão inteiramente singular que não há outras ou um número suficiente que permita tabular ocorrências iguais o bastante para formar uma base para qualquer inferência de valor sobre quaisquer probabilidades reais no caso em que estamos interessados. $O$ mesmo se aplica obviamente à maioria das condutas e não apenas às decisões empresariais. (o grifo é meu). (KNIGHT, 1921, apud BERNSTEIN, 1997:221).

O mesmo autor recorre ainda a Keynes para uma "crítica a visões tradicionais da probabilidade", afirmando que "nossa ignorância nega-nos o conhecimento certo (das) probabilidades; podemos apenas recorrer a estimativas" (antecipando o conceito de racionalidade limitada, que será tratado mais adiante). Em outras palavras, "Dificilmente descobriremos um método de reconhecer probabilidades específicas sem nenhuma ajuda da intuição ou do julgamento direto [...]. (KEYNES, 1921, apud BERNSTEIN, 1997:225, negrito deste autor). Este destaca ainda que a visão de Keynes “[...] gira, em última análise, em torno da incerteza [...] mais importante, incerteza sobre que lucro dada despesa em bens de capital dará”, ou seja, situação de decisões de estratégia empresarial:

As decisões tomadas pelas empresas sobre quanto gastar (e quando gastar) em novos prédios, novo maquinário, nova tecnologia e novas formas de produção constituem uma força dinâmica na economia. Entretanto, o fato de que essas decisões são essencialmente irreversíveis torna-as extremamente arriscadas, dada a ausência de qualquer guia objetivo da probabilidade de resultarem no planejado. (BERNSTEIN, 1997:227, negrito deste autor)

Por conhecimento "incerto" [...] não pretendo meramente distinguir o que se sabe ao certo do que é apenas provável. $\mathrm{O}$ jogo da roleta não está sujeito, nesse sentido, à incerteza [...]. O sentido em que estou usando o termo é aquele em que a perspectiva de uma guerra européia é incerta, ou o preço do cobre e a taxa de juro daqui a trinta anos [...]. Sobre estes assuntos, não há qualquer base científica para se formarem quaisquer probabilidades calculáveis. Nós simplesmente não sabemos. (KEYNES, 1937, apud BERNSTEIN, 1997:229, negrito deste autor) 
Não obstante as dificuldades discutidas acima, Bernstein (1997) afirma que "a capacidade de definir o que poderá acontecer no futuro é central às sociedades contemporâneas" e o domínio do risco constitui "a idéia revolucionária que define a fronteira entre os tempos modernos e o passado". Em outras palavras, as decisões estratégicas - complexas, irreversíveis e sujeitas a grande incerteza - precisam ser tomadas, da melhor forma possível.

Dada a discussão acima, é importante destacar que, a rigor, decisões estratégicas só podem ser avaliadas em função dos resultados que eventualmente venham a produzir. O decisor desconhece, a priori, todos os possíveis resultados e desdobramentos das alternativas consideradas; raramente tem possibilidade de estimar as probabilidades associadas a estes resultados; principalmente, não tem modo de certificar-se de que não exista uma alternativa "oculta" (desconhecida ou desconsiderada pelo decisor), melhor do que qualquer uma das alternativas consideradas.

Nestas condições, segundo Motta (s/d), o processo de análise e escolha entre as alternativas apresenta as seguintes características:

- Percepção de uma situação-problema: Existência de uma situação preocupante (ameaça) ou estimulante (oportunidade) presente ou futura;

- Múltiplos objetivos: Muitos alvos a serem atingidos, que normalmente competem entre si, ou seja, não podem ser atingidos concomitantemente;

- Múltiplas alternativas: Perspectivas diferentes sobre a natureza dos problemas, propostas variadas de solução, conflitos entre preferências e expectativas;

- Possibilidade de escolha: Existência de liberdade de escolha entre possíveis alternativas;

- Complexidade: Muitas informações, variadas, incompletas, valorizadas diferentemente pelos decisores e com impactos potencialmente diferentes;

- Risco: Apenas algumas probabilidades são conhecidas ou estimadas, com base em informações apenas parcialmente confiáveis; 
- Incerteza: Embora com alguma probabilidade de intervenção, por causa da imprecisão das informações e da dependência de interpretações, os resultados das ações são incertos;

- Ambigüidade: Muitas dimensões arbitrárias na definição do problema e pouca clareza sobre os valores dos decisores.

- Processo coletivo: Várias pessoas envolvidas na coleta e análise de dados.

- Múltiplos 'stakeholders': Diversas pessoas, grupos e organizações com interesses conflitantes quanto aos resultados da decisão.

O estudo dos processos decisórios (quadro abaixo) tem se caracterizado pela divisão conceitual entre abordagens normativas e descritivas (YU, 2008). As primeiras, desenvolvidas a partir da modelagem matemática dos processos decisórios (CLEMEN, 1996) indicam formas ideais e produzem modelos prescritivos para a tomada de decisões racionais, ou seja, decisões que buscam maximizar o valor econômico a ser obtido pelo decisor. Já as abordagens descritivas, produzidas a partir da pesquisa em psicologia social, buscam descrever como as pessoas realmente tomam decisões, considerando as limitações impostas tanto pela escassez de recursos, tempo, capacidade de processamento e outros, quanto pela influência de fatores psicológicos ou emocionais.

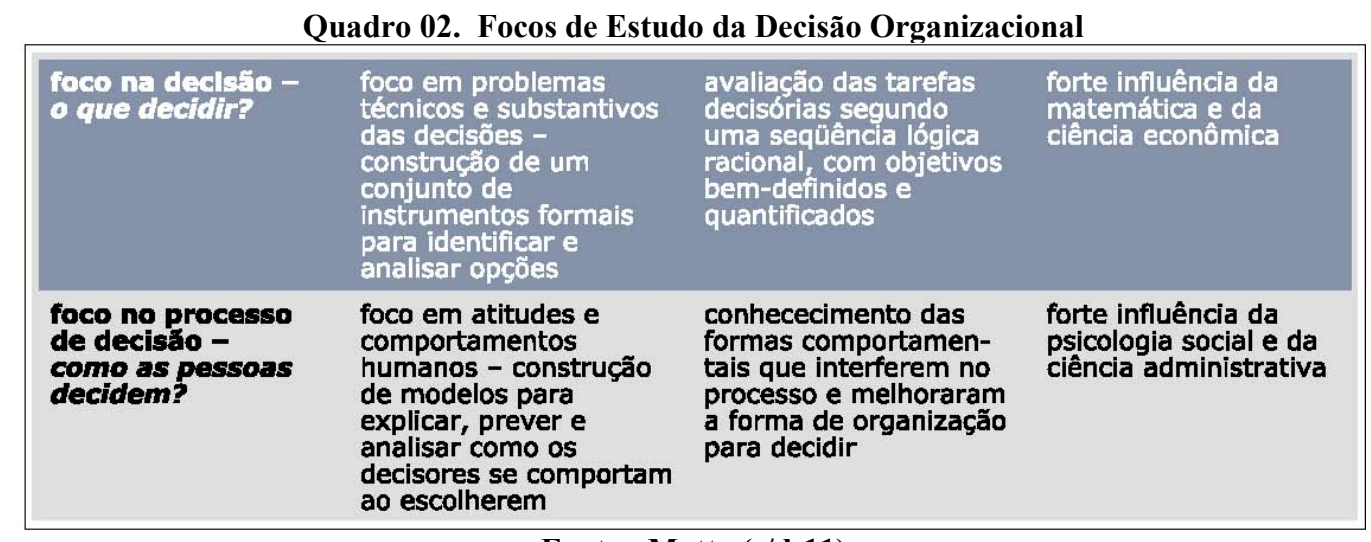

Fonte: Motta (s/d:11) 
As abordagens descritivas se baseiam fundamentalmente conceito de racionalidade limitada (bounded rationality), inicialmente formulado por Simon (1957, apud CAIN; JONES, 1979), em contraposição ao modelo do agente econômico racional, em particular a Teoria da Utilidade proposta por Bernoulli no século XVIII. Esta estabelece o conceito da busca sistemática da máxima utilidade (ganho econômico em relação à situação anterior) pelo decisor, que constitui o pressuposto conceitual das abordagens normativas.

Clemen (1996) salienta a diferença entre a qualidade da decisão - significando que o decisor procedeu a uma análise cuidadosa dos fatores relevantes e fez sua escolha a partir de um conjunto de critérios claramente estabelecidos - e seus resultados; uma decisão de qualidade pode levar tanto ao sucesso quanto ao fracasso (assim como uma decisão sem qualidade; em um exemplo extremo, alguém poderia jogar todas as suas economias na loteria - e ganhar!). "A ciência normativa da decisão assume que processos decisórios de qualidade têm maior probabilidade de conduzir a bons resultados”. (CLEMEN, 1991).

Este autor descreve métodos para auxiliar a estruturação do processo decisório, enfocando a importância de estabelecer uma hierarquia entre os objetivos da decisão - que geralmente conflitam entre si - de forma a proporcionar a geração de alternativas. Estes métodos consistem fundamentalmente na representação gráfica do problema a ser abordado, cujas formas mais utilizadas são o diagrama de influências e a árvore de decisões. $\mathrm{O}$ autor recomenda o emprego do diagrama de influências para desenvolver a estrutura de um problema complexo, uma vez que o método proporciona a representação compacta e intuitiva dos diversos elementos do problema abordado. A árvore de decisões mostra-se mais útil para representar e analisar os detalhes do problema e indicar a alternativa de solução mais adequada, tendo em vista a os critérios de preferência do decisor. 


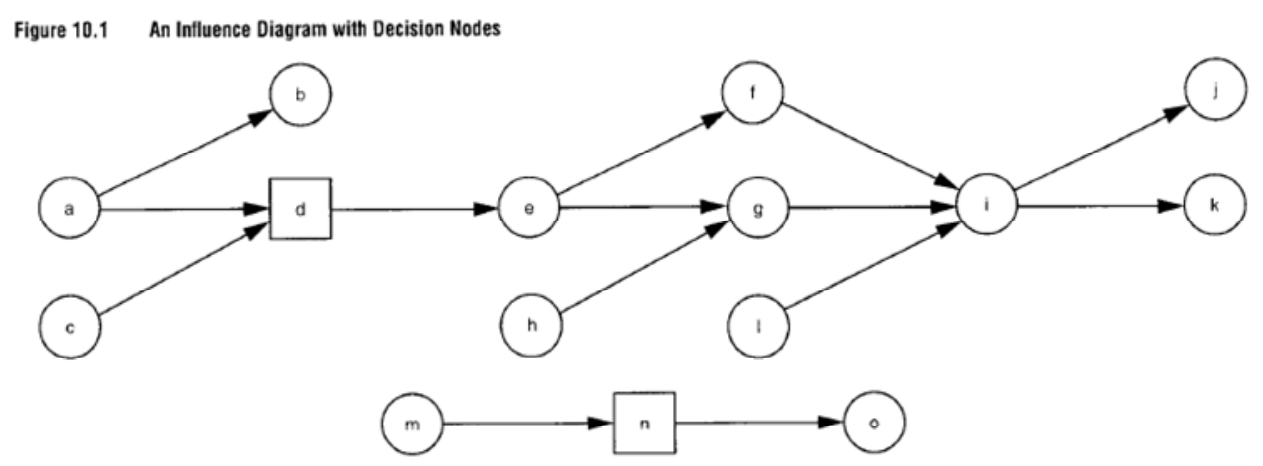

Figura 06 : Exemplo de diagrama de influências

Fonte: HOWARD; MATHESON (2005:133)

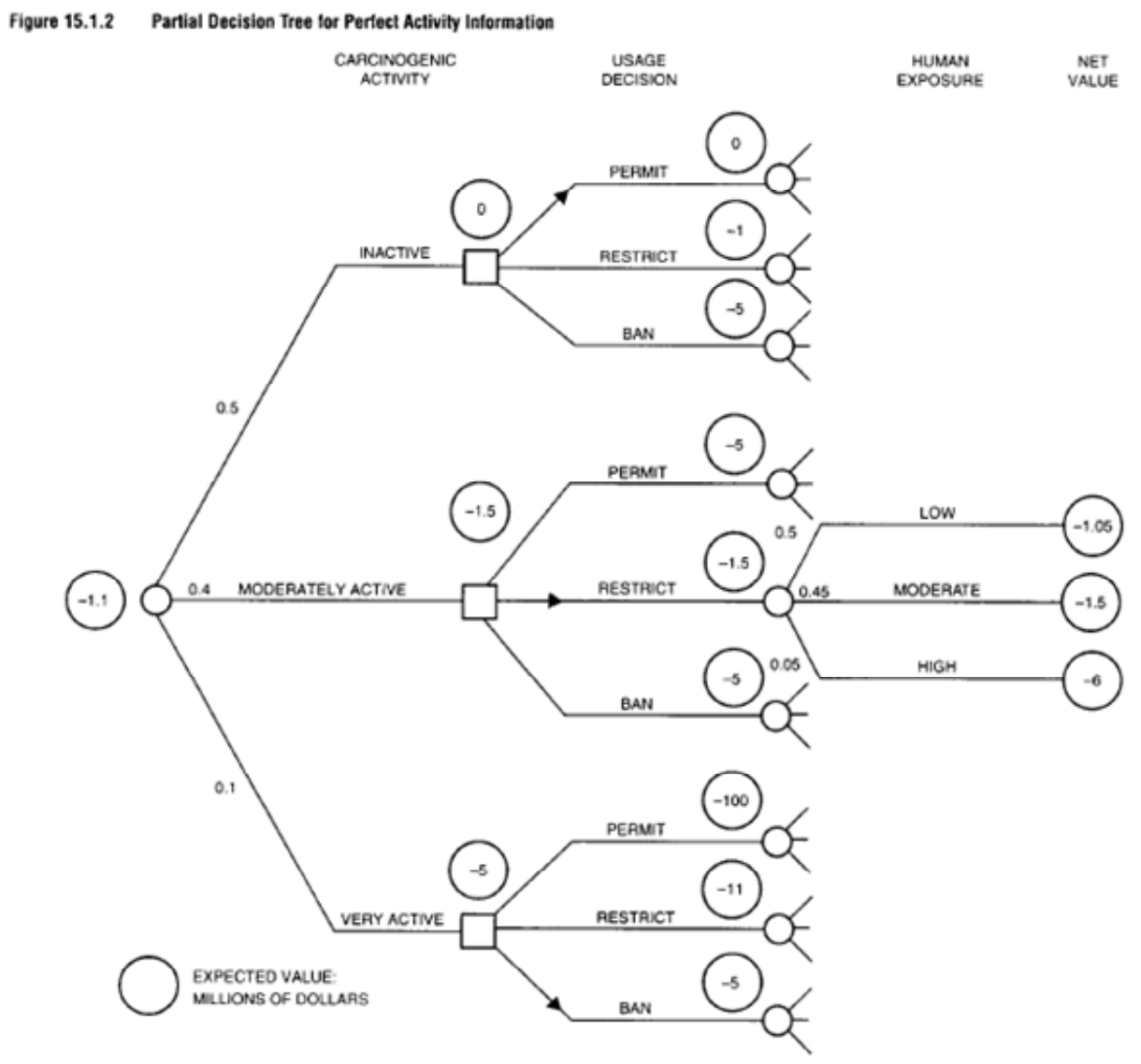

Figura 07 : Exemplo de árvore de decisão Fonte: HOWARD; MATHESON (2005:140)

Não é objetivo do presente estudo discutir detalhadamente o emprego destes métodos, mas principalmente ressaltar que os modelos prescritivos têm caráter normativo - não indicam 
como as decisões são tomadas, mas como deveriam ser tomadas, assumida a racionalidade do decisor. A racionalidade ideal pressupõe que o tomador da decisão possui um conhecimento exaustivo das possíveis alternativas e respectivas conseqüências e uma clara visão das suas preferências - atuais e futuras. A este respeito, March (1978) destaca que a dificuldade relacionada ao tratamento do risco e da incerteza consiste na antecipação tanto das possíveis conseqüências da escolha de uma determinada alternativa quanto da evolução das preferências dos decisores quanto a estas conseqüências. Em outras palavras, na prática (bem diferente das premissas da racionalidade ideal) as decisões envolvem vários objetivos concorrentes ou excludentes; critérios diversos sobre o valor de cada objetivo; incerteza quanto às possíveis conseqüências das ações, tanto quanto da evolução das preferências do tomador de decisões.

Portanto, os modelos normativos de apoio à decisão fornecem metodologias para orientar o processo de análise, conforme as características principais do problema e buscando a sua modelagem através da adoção de premissas simplificadoras (BRESSAN, 2004). Segundo a mesma autora, a metodologia conhecida como SMART (Simple Multi-attribute Rating Technique), desenvolvida por Edwards em 1971, pode ser utilizada como suporte às decisões perante múltiplos objetivos e critérios, a partir da identificação e classificação dos atributos relevantes, baseando-se nos seguintes pressupostos:

- Possibilidade de decisão - o decisor é capaz de comparar alternativas e determinar qual é mais atrativa.

- Transitividade - estabelecidas duas relações de preferência com elementos comuns, uma terceira relação de preferência sobre os mesmos elementos deve estar em conformidade lógica com as duas primeiras. Exemplo: se $\mathrm{A}>\mathrm{B}$ e $\mathrm{B}>\mathrm{C}$, então $\mathrm{A}>\mathrm{C}$.

- Adição - Implica que, se o decisor prefere A sobre B e B sobre C, então a força de preferência de A sobre $\mathrm{C}$ deve ser maior do que A sobre B. 
- Solubilidade - para um atributo, dada a identificação dos valores mais e menos atrativos, a solubilidade implica a capacidade de identificar as ocorrências reais que representam valores intermediários da escala de preferência.

- Valores mínimos e máximos finitos - determinação de uma faixa de possibilidades para os atributos, restrita às ocorrências ilustradas pelas alternativas e diferente do universo de possibilidades para aqueles atributos.

De forma geral, as metodologias de suporte às decisões se baseiam nesta estrutura. Como exemplo de método normativo adequado para pequenas empresas, pode ser citado o MIRA, desenvolvido por Almeida (2003). O MIRA se baseia na abordagem da Ecologia de Empresas, (EE, ZACCARELLI et al., 1980), surgida por volta da década de 60 nos EUA (e nos anos 70 no Brasil) e relacionada com o crescimento em importância das ciências biológicas e a uma certa decepção com a analogia mecanicista como forma de apreender a realidade organizacional. Em linhas gerais, os seguintes pontos são pressupostos da abordagem da Ecologia de Empresas:

- A ênfase no ambiente externo e uma preocupação com os inter-relacionamentos entre os subsistemas (departamentos, áreas ou empresas de uma rede de negócios;

- O ambiente, apresentado como um conjunto de forças externas à empresa e sobre as quais a empresa tem pouca influência, é o agente central na formação da estratégia;

- A organização deve responder a essas forças ou será "eliminada" (Teoria da Seleção Natural de Charles Darwin sobre a evolução das espécies, aplicada às organizações);

- As organizações acabam se agrupando em nichos distintos do tipo ecológico, posições nas quais permanecem até que os recursos (matérias primas, clientes, suportes governamentais etc.) se tornem escassos ou as condições demasiado hostis.

O método MIRA, concebido como um modelo de planejamento estratégico, se mostra adequado para fornecer suporte ao processo decisório em pequenas empresas; sua aplicação é muito facilitada por estar estruturada em uma seqüência de planilhas de Excel ${ }^{\circledR}$, dispensando ferramentas sofisticadas. Está estruturado em duas grandes etapas: Estabelecer a Estratégia e 
Viabilidade da Estratégia. Antes de iniciar estas atividades, o método MIRA prevê uma breve descrição da empresa e a declaração da sua Missão e Visão.

A descrição da empresa consiste em resumir o seu histórico, produtos, clientes e mercados e outras características julgadas relevantes. A missão/vocação da empresa constitui a sua razão de ser e serve para delimitar seu campo de ação e possibilidades de expansão. Tratando-se de uma pequena empresa, é normal a missão confundir-se com a vocação do principal gestor, geralmente o próprio dono, o mesmo ocorrendo com a declaração da visão, que constitui o grande objetivo e desafio da empresa (ALMEIDA, 2003).

A etapa de Estabelecer a Estratégia é a que apresenta maior interesse para os objetivos do presente estudo. Está dividida em quatro atividades, que podem ser realizadas em qualquer ordem: Análise dos Aspectos Internos, Análise do Ambiente, Comparação da Orientação com o Campo de Atuação e Estabelecimento da Estratégia. Em particular, a Análise do Ambiente se mostra muito útil ao gestor da pequena empresa, pois fornece uma estrutura conceitual para que este ordene e sistematize suas percepções sobre o ambiente de negócios. Esta é uma etapa fundamental no processo decisório, pois da análise ambiental dependem (a) o correto diagnóstico da situação-problema (atual), (b) a identificação das oportunidades e ameaças que definem a situação desejada e (c) o mapeamento dos fatores que influenciam a geração de alternativas estratégicas.

A partir dos elementos presentes no ambiente e na empresa, o método MIRA auxilia o decisor a gerar uma lista de ações estratégicas possíveis, que devem ser analisadas qualitativa e quantitativamente (utilizando planilhas que mostram a evolução patrimonial da empresa de acordo com os resultados projetados das ações estratégicas). Resultam deste processo o 
conjunto de ações estratégicas que deverão ser implementadas, juntamente com estimativas de tempo e recursos e atribuição de responsabilidades - o plano estratégico.

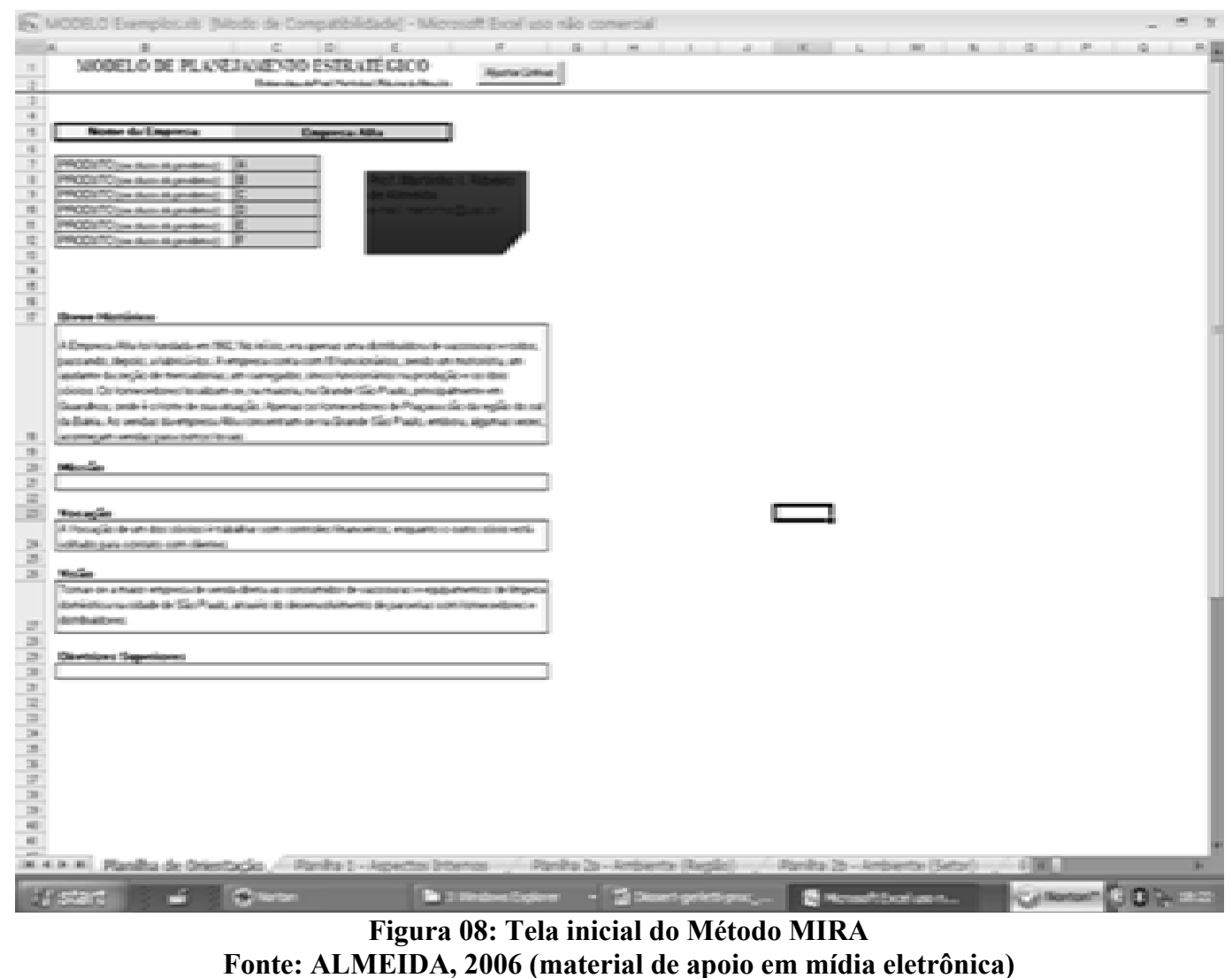

A estrutura conceitual do método MIRA pode ser utilizada para apoiar decisões específicas, tais como transações de participação societária envolvendo ou não novos sócios, investimentos em infra-estrutura e outras decisões de caráter estratégico. Cabe salientar que, conforme indicado por Maximiano (2007), geralmente uma decisão estratégica resulta em um projeto - "um esforço temporário empreendido para criar um produto, serviço ou resultado exclusivo" (PMI, 2004) - dado que este tipo de decisão implica necessariamente em mudanças na organização: desenvolver e/ou lançar produtos novos, construir, comprar, ou desativar uma fábrica, estabelecer uma parceria são exemplo de ações estratégicas, resultantes de decisões estratégicas. 
Em outras palavras, decisões estratégicas implicam em ações estratégicas, que deverão ser executadas de forma independente dos processos usuais da empresa, resultando em produtos únicos (por exemplo, uma nova fábrica, parceria estratégica, linha de produtos ou composição societária). Portanto, as ações estratégicas devem ser vistas e gerenciadas como projetos, ainda que a empresa não o reconheça explicitamente. O método MIRA incorpora estas considerações, ao incluir uma planilha que permite estabelecer as etapas iniciais do planejamento dos projetos estratégicos, que estruturam as ações estratégicas nas quais se traduzem as decisões estratégicas.

Por outro lado, Mintzberg salienta que quando se trata de decisões estratégicas, para as quais é preciso considerar uma grande quantidade de fatores (variáveis), em geral correlacionados de forma complexa e pouco conhecida, os modelos prescritivos "[...] falham ao lidar com a complexidade" (MINTZBERG et al, 1979). Em casos assim, o decisor deveria inicialmente definir quantos e quais fatores considerar e com que nível de precisão modelar o seu comportamento, conduzindo a uma "pré-decisão" entre lidar com uma modelagem matemática extremamente complexa ou analisar uma realidade complexa utilizando um modelo muito simplificado. Em suma, na prática "A administração é uma combinação de análise, intuição, experiência... e sorte”. (CRAINER, 1999, apud PAIVA, 2002).

A título de conclusão desta breve análise dos métodos prescritivos de apoio à decisão, cabe destacar que estes são apenas parcialmente normativos, ou seja, não estão livres da influência das características pessoais dos tomadores de decisão; qualquer que seja o método ou algoritmo adotado, a sua aplicação envolverá aspectos subjetivos. Em outras palavras, na realidade não são "agentes econômicos" que tomam decisões; pessoas tomam decisões nas organizações, as colocam em prática e eventualmente são afetadas pelas suas conseqüências e 
desdobramentos, que podem mostrar-se muito diferentes daqueles almejados ou previstos pelo decisor. Este componente essencialmente "humano" das decisões é destacado com ênfase por Keynes, que destaca a predominância do "impulso espontâneo para a ação" sobre a consideração "fria" das alternativas e probabilidades:

Most [...] decisions to do something positive [...] can only be taken as a result of animal spirits of a spontaneous urge to action rather than inaction, and not as the outcome of weighted average of quantitative benefits multiplied by quantitative probabilities. (KEYNES, 1935, apud CADMAN, 1973:70)

Partindo destas considerações, são discutidas a seguir as abordagens descritivas, que buscam analisar como as pessoas realmente tomam decisões. Simon (1957, apud CAIN; JONES, 1979) sugere que para tomar decisões em situações complexas, diante de das limitações impostas pela impossibilidade de computar a utilidade esperada de cada alternativa e pela limitação do tempo disponível para cada decisão (diversas atividades desenvolvidas simultaneamente), as pessoas simplesmente não empregam as rígidas regras de otimização que constituem a base conceitual dos métodos prescritivos. Segundo este autor, normalmente o indivíduo considera apenas parte das informações e alternativas disponíveis - a racionalidade limitada - e conduz o processo de análise racional até um ponto a partir do qual a solução é escolhida de forma intuitiva.

Em outras palavras, geralmente o tomador de decisão procura uma solução para o problema até encontrar uma alternativa satisfatória, utilizando diversas heurísticas na busca de uma solução que apresente um equilíbrio aceitável entre a qualidade da decisão e os custos de deliberação (deliberation costs). Por esta contribuição, Simon recebeu um Prêmio Nobel de Economia em 1978, tendo sido o seu trabalho posteriormente ampliado por diversos autores, entre os quais se destaca Daniel Khaneman, que também recebeu o Nobel de Economia em 2002 pelo seu trabalho em parceria com Amos Tversky. 
Abordando a questão das decisões organizacionais, Simon (1979) aponta a necessidade das organizações buscarem um maior grau de racionalidade dos seus processos decisório do que o possível de ser obtido nas decisões individuais. O autor afirma que a racionalidade nas organizações depende de mecanismos integradores que (1) provocam o início do comportamento em determinada direção e (2) mantém o comportamento na direção estabelecida, em um processo dividido em três etapas:

a) O indivíduo ou organização toma decisões estruturadoras amplas, quanto aos valores e métodos gerais (planejamento substantivo / decisões estratégicas);

b) Estabelece os mecanismos que permitirão que as decisões específicas diárias se conformem ao planejamento substantivo (planejamento processual / decisões táticas);

c) Executa as ações (estratégicas) através de decisões e atividades diárias (operacionais), orientadas pelas políticas estabelecidas pelas decisões estruturadoras anteriores.

\footnotetext{
Desse modo, um dos problemas mais importantes da teoria administrativa consiste em determinar de que maneira essa rede de decisões deve ser construída, qual a divisão de trabalho adequada entre as amplas decisões planejadoras e as decisões executoras mais restritas. O segundo problema fundamental diz respeito ao planejamento processual: à criação de mecanismos que tornem efetivo o controle das decisões executivas a partir das decisões planejadoras. (Simon, 1979: 100).
}

As decisões estratégicas, foco do presente estudo, são exatamente estas decisões estruturadoras amplas, que se referem aos valores e métodos gerais e cujo encadeamento constitui o planejamento substantivo - cuja discussão será retomada no item 2.3, que se refere especificamente ao processo decisório estratégico. Antes, são discutidos no item 2.2 a seguir aspectos gerais das decisões individuais, com ênfase em algumas decorrências da racionalidade limitada: o emprego de heurísticas e as influências dos vieses cognitivos, da percepção do risco e do estilo cognitivo do tomador de decisão. 


\subsection{Teoria da decisão individual}

Conforme já discutido, incerteza e risco estão na base da tomada de decisões. Bernstein (1997) destaca que a moderna noção de risco é bastante recente; a Teoria das Probabilidades começou a ser desenvolvida por Pascal e Fermat em meados do século XVII e apenas no século seguinte Jacob Bernoulli “[...] formulou a Lei dos Grandes Números e os métodos de amostragem estatística [... e...] Abraham de Moivre expôs a estrutura da distribuição normal, $[\ldots]$ ", posteriormente desenvolvida por Gauss, que empresta seu nome à curva em sino que a representa. Em 1738, Daniel Bernoulli, sobrinho de Jacob, formulou a Teoria da Utilidade, baseada nos conceitos centrais de que cada agente econômico busca sempre maximizar não o valor absoluto do ganho (que pode ser expresso pela sua expectativa matemática, ou seja, o produto do valor do ganho pela probabilidade de obtê-lo), mas a sua utilidade; e que a utilidade percebida de um aumento marginal da riqueza é inversamente proporcional à riqueza possuída anteriormente.

Bernstein afirma ainda que "[...] a Teoria da Utilidade tornou-se o paradigma favorito na definição de quanto risco as pessoas correrão na esperança de obter algum ganho desejável, mas incerto"; e que o seu emprego pelos economistas do século XIX "levou diretamente à lei da oferta e da procura", que constitui um dos pilares das teorias econômicas clássicas. Segundo estas teorias, o "decisor ideal" deveria (i) possuir conhecimento, tempo e recursos para identificar e avaliar todas as alternativas relevantes, (ii) ter estabelecido um sistema claro de preferências e (iii) agir de forma coerente com a racionalidade da análise. Em outras palavras, a racionalidade ideal pressupõe que o tomador da decisão possui um conhecimento exaustivo das possíveis alternativas e respectivas conseqüências e uma clara visão das suas preferências presentes e futuras (MARCH, 1978), o que claramente não se verifica na prática.

A teoria econômica tradicional postula um "homem econômico", o qual, sendo 'econômico', é também "racional". Assume-se que ele possua conhecimento dos aspectos relevantes do seu 
ambiente, que se não absolutamente completo, é ao menos impressionantemente claro e volumoso. Assume-se ainda que ele tenha um sistema de preferências bem organizado e estável, e uma habilidade computacional para calcular, dadas as alternativas de ação disponíveis, qual delas irá permiti-lo atingir a maior pontuação na sua escala de preferências. (SIMON, 1965:99, apud BRESSAN, 2004:18).

A partir destas considerações, Simon (1979) afirma que a racionalidade humana é limitada; em outras palavras, nenhum decisor tem a capacidade de listar e analisar todos os fatores, critérios e alternativas envolvidos em uma decisão organizacional:

[...] no comportamento real, que se distingue do comportamento objetivamente racional, a decisão é desencadeada pelos estímulos que canalizam a atenção em direções definidas e a resposta aos estímulos é em parte deliberada, embora provenha, na sua grande parte do hábito. A parte que provém do hábito não é, decerto, necessária ou geralmente irracional, já que pode representar um ajustamento ou adaptação previamente condicionada do comportamento a seus fins. [...] o número de estímulos que requerem, como respostas, comportamentos, é muito maior do que o número de respostas que poderiam ser postas em prática [...]. A racionalidade exige que se faça uma escolha consciente entre valores competitivos, sem se deixar levar pelo capricho dos estímulos que dirigem a atenção.” (SIMON, 1979:95).

O trabalho de Simon - pelo qual recebeu um prêmio Nobel de Economia - estabeleceu um contraponto às abordagens normativas, baseadas no modelo do agente econômico racional proposto por Bernoulli no século XVIII e nos seus desenvolvimentos posteriores. Simon pode ser considerado o criador do enfoque comportamental do estudo dos processos decisórios, que busca descrever como as pessoas realmente tomam decisões (abordagens descritivas).

Os estudos de Simon sobre a racionalidade humana foram complementados por vários autores, com destaque para Amos Tverzky e Daniel Kahneman - que também recebeu um Nobel de Economia. É interessante notar que tanto Simon quanto Kahneman, ambos pesquisadores na área da Psicologia Social, foram agraciados com o Nobel de Economia pelas suas contribuições para a compreensão das decisões econômicas, em especial pela importância dos seus resultados para a modelagem matemática dos processos decisórios. Em outras palavras, estes resultados de pesquisas descritivas em ciências sociais influenciaram fortemente a pesquisa quantitativa em Economia. (NAGELSCHIMIDT, 2007). 
Amos Tverzky e Daniel Kahneman ampliaram o conceito de racionalidade limitada e sua influência sobre o comportamento, com uma longa série de trabalhos publicados principalmente ao longo dos anos 1970 e 80 . Estes enfocaram principalmente a questão das heurísticas e vieses presentes nos julgamentos sob incerteza e a modelagem das escolhas sob risco e aversão a perdas, que culminaram com a publicação em 1979 da Teoria dos Prospectos (Prospect Theory), que será apresentada mais adiante. Segundo estes autores, os tomadores de decisão utilizam heurísticas - regras práticas para lidar com a complexidade na busca de uma solução satisfatória para a situação-problema. O processo de avaliação e escolha está sujeito a desvios da racionalidade devidos fundamentalmente a vieses cognitivos - erros sistemáticos devidos a limitações cognitivas - e ao efeito dos assim chamados framing effects, que constituem inconsistências provocadas por alterações aparentemente irrelevantes na forma de se descrever a situação-problema.

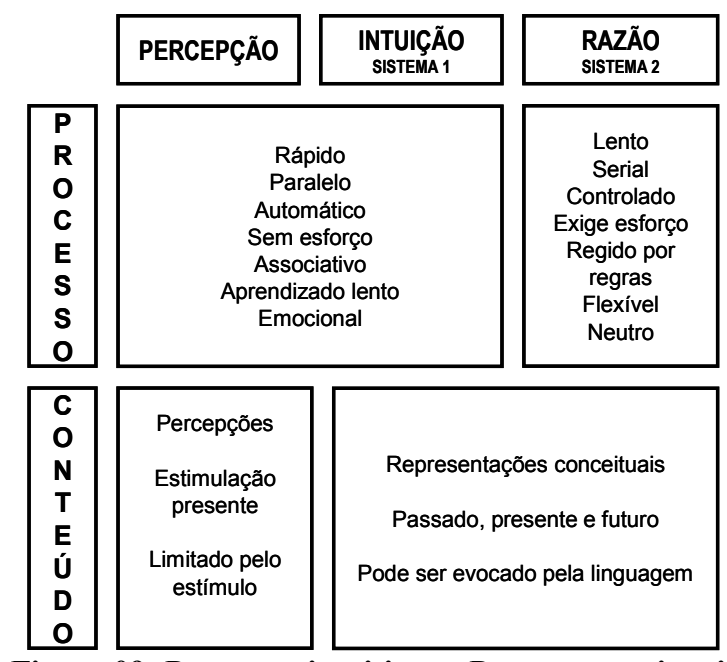

Figura 09: Processos intuitivos e Processos racionais

Fonte: Adaptado de Kahneman, 2003:1451

A análise do emprego de heurísticas nos processos decisórios está inserida no contexto da discussão dos conceitos de razão e intuição, que correspondem respectivamente a comportamentos de hesitação-escolha e estímulo-resposta; razão se refere a processos 
mentais seqüenciais, deliberados e que exigem exclusividade (concentração) e esforço, enquanto por intuição se entendem os processos imediatos e espontâneos, que atendem à maior parte das atividades diárias. Para distinguir estes dois processos, Stanovitch \& West (2000, apud KAHNEMAN, 2003) propuseram o modelo esquematizado na figura acima.

Segundo Bazerman (2004), o uso das heurísticas não garante a solução ótima, todavia a economia de tempo e recursos provavelmente compensará a eventual perda de valor da solução adotada; em outras palavras, trata-se de um trade-off entre o custo da análise e as possíveis perdas resultantes de não identificar a solução ideal. Heurísticas geralmente são muito úteis, porém seu uso inadequado pode levar a graves erros de julgamento, principalmente quando o tomador de decisão as utiliza inconscientemente; em especial, merecem destaque três heurísticas cognitivas que parecem afetar todos os indivíduos: disponibilidade, representatividade e ajuste.

A heurística da disponibilidade leva os indivíduos a avaliar a freqüência, probabilidade ou possível causa de um evento pelo grau com que exemplos de eventos deste tipo estão disponíveis na memória. Mostra-se útil na medida em que eventos mais freqüentes tendem a estar mais presentes na memória, porém pode levar a erros na medida em que a disponibilidade de informações é afetada por fatores sem relação com a freqüência real. A heurística da representatividade consiste em avaliar um evento a partir da sua semelhança com uma categoria conhecida ou estereótipo formado anteriormente. Embora possa fornecer boas indicações, oferece o perigo do julgamento baseado em preconceitos. Já ancoragem e ajuste consistem nas influências sobre o julgamento de valores ou conceitos oferecidos por informações históricas ou outras fontes que podem não ser relevantes (idem). 
Estas heurísticas introduzem desvios da racionalidade - ditos vieses, termo "emprestado" da

Estatística para designar erros sistemáticos introduzidos pela adoção de hipóteses

simplificadoras - que eventualmente podem comprometer as análises e portanto afetar

gravemente a qualidade das decisões, geralmente sem que o tomador de decisão tenha

consciência do processo e das suas conseqüências. As principais heurísticas e os vieses

cognitivos que lhes são associados estão descritos resumidamente no próximo quadro.

Quadro 03: Resumo dos vieses cognitivos

Fonte: adaptado de Bazerman (2004:50--51)

\begin{tabular}{|c|c|}
\hline Viés & Descrição \\
\hline \multicolumn{2}{|c|}{ Vieses que emanam da heurística da disponibilidade } \\
\hline $\begin{array}{l}\text { Facilidade de } \\
\text { lembrança }\end{array}$ & $\begin{array}{l}\text { Indivíduos julgam que eventos mais facilmente lembrados são mais freqüentes do } \\
\text { que os menos lembrados }\end{array}$ \\
\hline Recuperabilidade & $\begin{array}{l}\text { A avaliação da freqüência de eventos sofre viés com base no modo que a } \\
\text { estrutura da memória afeta o processo de busca }\end{array}$ \\
\hline $\begin{array}{l}\text { Associações } \\
\text { pressupostas }\end{array}$ & $\begin{array}{l}\text { Indivíduos tendem a superestimar a probabilidade de eventos ocorrerem } \\
\text { concomitantemente com base na quantidade de associações semelhantes que } \\
\text { podem recordar facilmente }\end{array}$ \\
\hline \multicolumn{2}{|c|}{ Vieses que emanam da heurística da representatividade } \\
\hline $\begin{array}{l}\text { Insensibilidade aos } \\
\text { indices básicos }\end{array}$ & $\begin{array}{l}\text { Ao avaliar probabilidades, indivíduos tendem a ignorar índices básicos em função } \\
\text { de descrições informativas, mesmo irrelevantes }\end{array}$ \\
\hline $\begin{array}{l}\text { Insensibilidade ao } \\
\text { tamanho da amostra }\end{array}$ & $\begin{array}{l}\text { Indivíduos tendem a desconsiderar o papel do tamanho da amostra ao avaliar } \\
\text { informações amostrais }\end{array}$ \\
\hline $\begin{array}{l}\text { Interpretação errada } \\
\text { da chance }\end{array}$ & $\begin{array}{l}\text { Indivíduos esperam que um processo aleatório "pareça" aleatório, independente } \\
\text { da validade estatística da expectativa }\end{array}$ \\
\hline Regressão à média & $\begin{array}{l}\text { Indivíduos são propensos a ignorar o fato de que eventos extremos tendem a } \\
\text { regredir à média em tentativas subseqüentes }\end{array}$ \\
\hline Falácia da conjunção & $\begin{array}{l}\text { Indivíduos julgam erroneamente que conjunções são mais prováveis que } \\
\text { conjuntos mais globais de eventos que englobam a conjunção }\end{array}$ \\
\hline \multicolumn{2}{|c|}{ Vieses que emanam da heurística da representatividade } \\
\hline $\begin{array}{l}\text { Ajuste insuficiente da } \\
\text { ancora }\end{array}$ & $\begin{array}{l}\text { Indivíduos estimam valores com base em informações disponíveis e usualmente } \\
\text { fazem ajustes insuficientes para estabelecer o valor final }\end{array}$ \\
\hline $\begin{array}{l}\text { Vieses de eventos } \\
\text { combinados }\end{array}$ & $\begin{array}{l}\text { Indivíduos superestimam a probabilidade de eventos conjuntivos e subestimam a } \\
\text { probabilidade de eventos disjuntivos }\end{array}$ \\
\hline Excesso de confiança & $\begin{array}{l}\text { Indivíduos tendem a exibir excesso de confiança quanto aos seus julgamentos ao } \\
\text { responder questões difíceis }\end{array}$ \\
\hline \multicolumn{2}{|c|}{ Dois vieses mais gerais } \\
\hline \multirow{2}{*}{$\begin{array}{l}\text { A armadilha da } \\
\text { confirmação } \\
\text { (hindsight) e a } \\
\text { maldição do } \\
\text { conhecimento }\end{array}$} & $\begin{array}{l}\text { Indivíduos tendem a buscar informações que confirmem o que acham que é } \\
\text { verdadeiro, evitando procurar evidências desafiadoras }\end{array}$ \\
\hline & $\begin{array}{l}\text { Após saber que um evento ocorreu, indivíduos tendem a superestimar até que } \\
\text { grau eles teriam previsto o resultado correto. Além disso, não ignoram } \\
\text { informações que eles têm, mas outros não, para prever os seus comportamentos. }\end{array}$ \\
\hline
\end{tabular}


Ainda a respeito de desvios da racionalidade, Ariely (2008) destaca que as escolhas irracionais apresentam padrões previsíveis, presumivelmente decorrentes dos vieses cognitivos discutidos acima. O autor afirma que "[...] os humanos raramente fazem escolhas absolutas. Não temos um medidor interno que nos avisa quanto vale cada coisa. Pelo contrário, nos concentramos na vantagem relativa de uma coisa sobre a outra [...].” - a chamada relatividade - destacando ainda que “[...] estamos propensos a nos concentrar em comparações de coisas fáceis de comparar". A partir desta idéia central, o autor analisa diversas situações nas quais a tendência a escolhas contrárias à racionalidade se mostra de forma sistemática:

- Alternativa chamariz: na situação de comparação entre alternativas A e B dificilmente comparáveis, a presença de uma terceira, nitidamente inferior a A (-A) aumenta significativamente a preferência por A em relação a B (se A é melhor do que -A, então provavelmente A é melhor do que B - uma afirmação sem qualquer base racional).

- Criação de âncoras arbitrárias: valores arbitrários podem estabelecer âncoras para a comparação de alternativas. Por exemplo, o histórico de vendas do produto A ser utilizada como base para avaliar a decisão lançamento do Produto B.

- Coerência arbitrária: uma vez criada uma âncora, esta influencia outras decisões semelhantes de forma duradoura.

- Comportamento de manada: Uma decisão é influenciada por uma decisão do mesmo tipo de outra pessoa, de forma arbitrária. Por exemplo, o "padrão de mercado" de investimentos em Marketing (que não faz qualquer sentido do ponto de vista estratégico).

- Comportamento habitual: Uma decisão é influenciada por uma decisão do mesmo tipo da mesma pessoa, de forma arbitrária. Por exemplo, decidir os investimentos em Marketing deste ano em função do valor investido no ano anterior (que tampouco faz qualquer sentido). 
Estes são exemplos de comportamentos claramente contrários à racionalidade, todavia muito comuns. De forma semelhante ao conceito de "prisão psíquica" (MORGAN, 1996) discutido mais acima, a relatividade inerente ao comportamento de escolha introduz um elemento novo na análise da decisão: a influência de aspectos inconscientes, sobre os quais o decisor aparentemente não tem qualquer controle.

Ainda a respeito de escolhas sob risco e incerteza, Kahneman e Tversky (1979, 1992, apud BAZERMAN, 2004) propuseram a Teoria Perspectiva ou Teoria dos Prospectos (Prospect Theory), um modelo descritivo das decisões sob risco que se contrapõe ao paradigma clássico. Partindo da conceituação fundamental da Teoria da Utilidade de Bernoulli, a Teoria dos Prospectos busca descrever como as pessoas realmente tomam decisões sob incerteza. Fundamentalmente, a Teoria dos Prospectos introduz considerações sobre a influência de emoções como a aversão a perdas, em função de expectativas de mudanças em relação à situação atual - o status quo. Segundo a Teoria da Utilidade, ganhos e perdas teriam o mesmo valor; por exemplo, $50 \%$ de chance de ganhar 1000 é equivalente a $50 \%$ de chance de não perder 1000 e ambas equivalentes a um ganho certo de 500, que representa o equivalente de certeza das duas situações anteriores. Os achados dos autores indicam que, na verdade, o equivalente de certeza tende a ser diferente em situações de possíveis ganhos ou perdas; na “zona de ganhos", em geral as pessoas se mostram avessas ao risco, enquanto na "zona de perdas" predomina a propensão ao risco.

Na Teoria dos Prospectos, são levados em conta os efeitos da aversão a perdas e ao arrependimento; descrições equivalentes de um mesmo resultado podem levar a escolhas diferentes, simplesmente destacando aspectos ligados a ganhos ou perdas e as decisões são influenciadas pelo "enquadramento" (framing) dos elementos da questão considerada. Assim 
sendo, variações "irrelevantes" na descrição do problema afetam a acessibilidade das alternativas e portanto, as decisões. Os principais conceitos da Teoria dos Prospectos, ilustrados na figura a seguir, são os seguintes:

- em geral, as pessoas preferem o risco diante da perspectiva de perdas e o evitam quando se trata de ganhos;

- o valor é percebido principalmente em termos de mudanças em relação a um ponto neutro e a aversão à perda predomina sobre a expectativa de ganho;

- a teoria considera resultados em termos de mudanças e a possível influência das emoções sobre as escolhas.

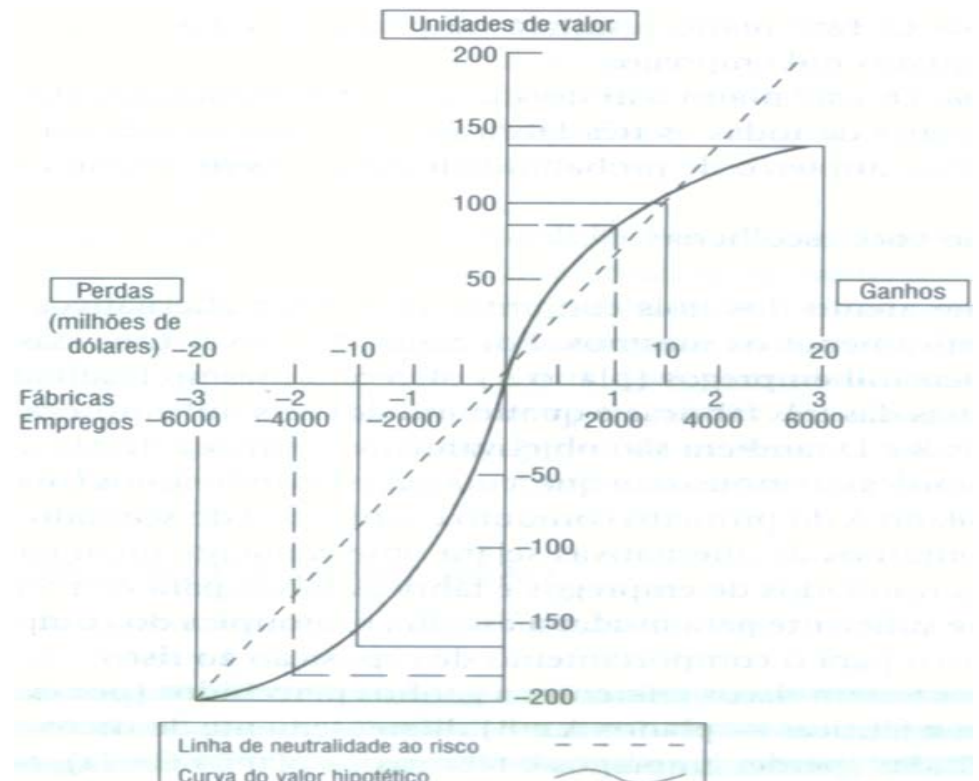

Figura 10- Teoria dos Prospectos FONTE: BAZERMAN, 2004:62

Kahneman \& Frederick (2002, apud KAHNEMAN, 2003) afirmam ainda que os indivíduos procuram reduzir a complexidade de determinadas tarefas cognitivas substituindo um atributo relevante de difícil tratamento (target attribute) por outro mais "fácil" (heuristic attribute), tendendo a substituir os processos deliberados de análise por avaliações influenciadas por aspectos emocionais e preferências pessoais. Em síntese, Kahnemann (2003) e Bazerman (2004) desenvolvem as noções de acessibilidade, heurísticas e vieses, descrevendo os principais processos através dos quais as pessoas fazem escolhas e tomam decisões. Estes 
autores sugerem que raramente as pessoas decidem de forma racional, ressaltando ainda que processos intuitivos podem se mostrar superiores à análise sistemática, principalmente no caso de um decisor experimentado em situação crítica.

Segundo Khatri; Alvin (2000), Jung afirma que a intuição "não denota algo contrário à razão, mas sim algo além do domínio da razão" e Vaughan define intuição como "uma função psicológica 'sintética' que apreende a totalidade de uma situação". Estes autores descrevem a intuição como subconsciente, complexa, rápida, "não emoção" - destacando que os estados emocionais tais como raiva, medo, ansiedade comprometem a percepção intuitiva (intuitive perception) - e não viesada, no sentido que os vieses cognitivos afetam de modo semelhante todas as decisões, sendo que a intuição "é central mesmo nas decisões baseadas em fatos [...] os métodos racionais raramente podem ser usados exclusivamente; no mínimo, o decisor precisa usar a intuição para reunir os dados [...] em toda decisão existe um componente intuitivo.” (GOLDBERG, 1990, apud KHATRI; ALVIN, 2000, grifo deste autor),

Entre outros autores que se dedicaram ao estudo do papel da intuição nas decisões organizacionais, Parikh et al (1998) realizaram uma ampla pesquisa sobre a importância do uso da intuição pelos executivos. A pesquisa envolveu cerca de 1.200 gerentes sênior de centenas de grandes empresas em oito países, inclusive no Brasil. De forma geral, a pesquisa indicou que os administradores freqüentemente empregavam a intuição para tomar decisões, em especial aquelas mais complexas e críticas. A pesquisa de Parikh et al (1998) indicou que os administradores seniores - ou seja, aqueles com mais tempo de carreira em cargos mais elevados - tendiam a empregar mais a intuição do que os seus colegas menos experientes. 
Considerando que os administradores seniores são aqueles que devem tomar as decisões mais fortemente influenciadas pelas incertezas do ambiente externo e mais críticas para a organização, o citado estudo parece indicar que a importância da intuição cresce com (1) a complexidade, turbulência e competitividade do ambiente no qual a empresa atua (2) o nível do administrador e sua influência sobre os rumos da empresa; vale notar que a pesquisa de Parikh et al (1998) não examinou administradores de pequenas empresas.

Neste item, foram discutidos diversos aspectos dos processos decisórios, enfocando a questão da racionalidade e suas limitações; estas conduzem o decisor ao emprego de heurísticas, que eventualmente introduzem vieses (desvios sistemáticos da racionalidade). Finalmente, foi brevemente analisado o papel da intuição, entendida como a capacidade de tomar decisões adequadas, aparentemente sem avaliação sistemática das alternativas e preferências do decisor. O próximo item é dedicado à discussão do processo decisório estratégico.

\subsection{Processo decisório estratégico (PDE)}

A discussão desenvolvida até este ponto sugere que a racionalidade das decisões organizacionais está relacionada à ordenação dos fatores envolvidos (problema, alternativas, preferências) de forma a direcionar as decisões. A este respeito, Simon (1979) postula a existência nas organizações de mecanismos integradores que (1) provocam o início do comportamento em determinada direção (sensibilidade a estímulos externos) e (2) mantém o comportamento na direção estabelecida (mecanismos internos de persistência do comportamento). O processo de integração do comportamento pode ser descrito como dividido em três etapas fundamentais:

a) O indivíduo (ou a organização) toma decisões amplas, relativas aos valores que orientarão sua atividades, aos métodos gerais... . Esta atividade pode ser chamada planejamento substantivo. 
b) Projeta e estabelece os mecanismos que dirigirão sua atenção... de modo a permitir que as decisões específicas diárias se conformem ao planejamento substantivo... [planejamento processual]... .c) executa o plano através de decisões e atividades diárias que se enquadram no arcabouço propiciado pelas etapas a) e b).. (SIMON,1979:100, grifo deste autor).

Pode-se assim entender o planejamento substantivo como o conjunto das decisões estratégicas, cujas implicações limitam o campo das alternativas disponíveis no âmbito do planejamento processual e operacional posteriores, o que parece favorecer a racionalidade. Em outras palavras, o processo de planejamento constitui um compromisso entre a racionalidade ideal e as limitações de tempo e recursos, ao identificar e considerar apenas algumas alternativas plausíveis no processo de tomada de decisão, aceitando-se o risco de eliminar a "melhor” alternativa possível em favor de uma alternativa “apenas" satisfatória.

\begin{abstract}
A estratificação de decisões permite que cada escolha seja guiada [...] por considerações muito mais amplas de fatores racionais do que seria possível [...] sem o benefício das considerações prévias. Isso nos leva ao conceito de comportamento planejado como o meio mais adequado de manter um alto grau de racionalidade. [...] Os processos psicológicos envolvidos no planejamento consistem na seleção dos critérios gerais de escolha e subseqüentemente, seu detalhamento para aplicá-los a situações específicas. (idem, p.103).
\end{abstract}

Simon (1947, apud FREITAS; MACADAR; MOSCAROLA, 1997) descreveu da seguinte maneira as fases do processo de tomada de decisão:

i) Inteligência ou investigação: exploração do ambiente e análise prévia dos dados e variáveis relativas à situação em busca de indícios de problemas e/ou oportunidades;

ii) Desenho ou concepção: formulação do problema e desenvolvimento e análise das alternativas disponíveis;

iii) Escolha: seleção de uma alternativa ou curso de ação;

iv) Feedback: em qualquer fase, o decisor pode voltar a uma fase anterior, visando identificar e/ou reavaliar alternativas.

A discussão acima sobre os aspectos gerais do processo decisório pode ser direcionada para as decisões de caráter estratégico a partir do estudo de Mintzberg et al (1976), uma pesquisa 
de campo que abordou vinte e cinco processos decisórios estratégicos. Estes autores destacam que os modelos prescritivos de apoio à decisão, embora abundantes na literatura administrativa, têm feito pouca diferença na realidade das decisões estratégicas, por não conseguirem lidar com a sua complexidade; e identificam uma estrutura básica subjacente aos processos aparentemente não-estruturados da tomada de decisão estratégica, propondo então um modelo processual para este tipo de decisão, baseado na conceituação de Simon (acima).

Os autores inicialmente identificam três linhas de pesquisa sobre decisões organizacionais: pesquisas sobre decisões individuais, decisões em grupo (cujos resultados os autores consideram de pouca relevância para a análise de decisões organizacionais) e decisões organizacionais. Os principais pesquisadores e resultados sobre decisões individuais são Newell e Simon (Human Problem Solving, 1972), identificando os processos de "fatorar decisões inéditas e complexas em sub-decisões mais simples e familiares”, baseando-se em decisões anteriores para identificar atalhos conceituais (heurísticas) em busca de soluções satisfatórias. Na pesquisa sobre decisões organizacionais, os autores destacam os resultados de Cyert, March, Simon e outros, "que produziram uma série de insights".

A pesquisa reportada no artigo em questão analisou vinte e cinco processos decisórios estratégicos envolvendo cinqüenta equipes de alunos de mestrado, que estudaram cada organização por um período de três a seis meses. Fundamentalmente, cada equipe identificou uma decisão estratégica e a estudou aplicando um questionário semi-estruturado aos responsáveis pela decisão estudada. A análise destas decisões indicou que o processo decisório estratégico é caracterizado por ser inédito, complexo e por não ter limites prédeterminados (openendness), pois a organização inicia o processo com conhecimentos 
limitados sobre a situação-problema, as possíveis soluções e as suas prováveis conseqüências, implicações e desdobramentos.

O estudo abordou três aspectos do processo decisório estratégico: o estímulo inicial (problema ou oportunidade) que o iniciou; o tipo de solução (padronizada ou personalizada) a ser adotada; e o método utilizado para a decisão, que será tratado em detalhe adiante. Em acordo com Simon (1965) e Witte (1972), os autores sugerem um processo em três fases identificação, desenvolvimento e seleção - caracterizadas por sete "rotinas centrais" e três conjuntos de "rotinas de apoio", esquematizadas na figura a seguir.

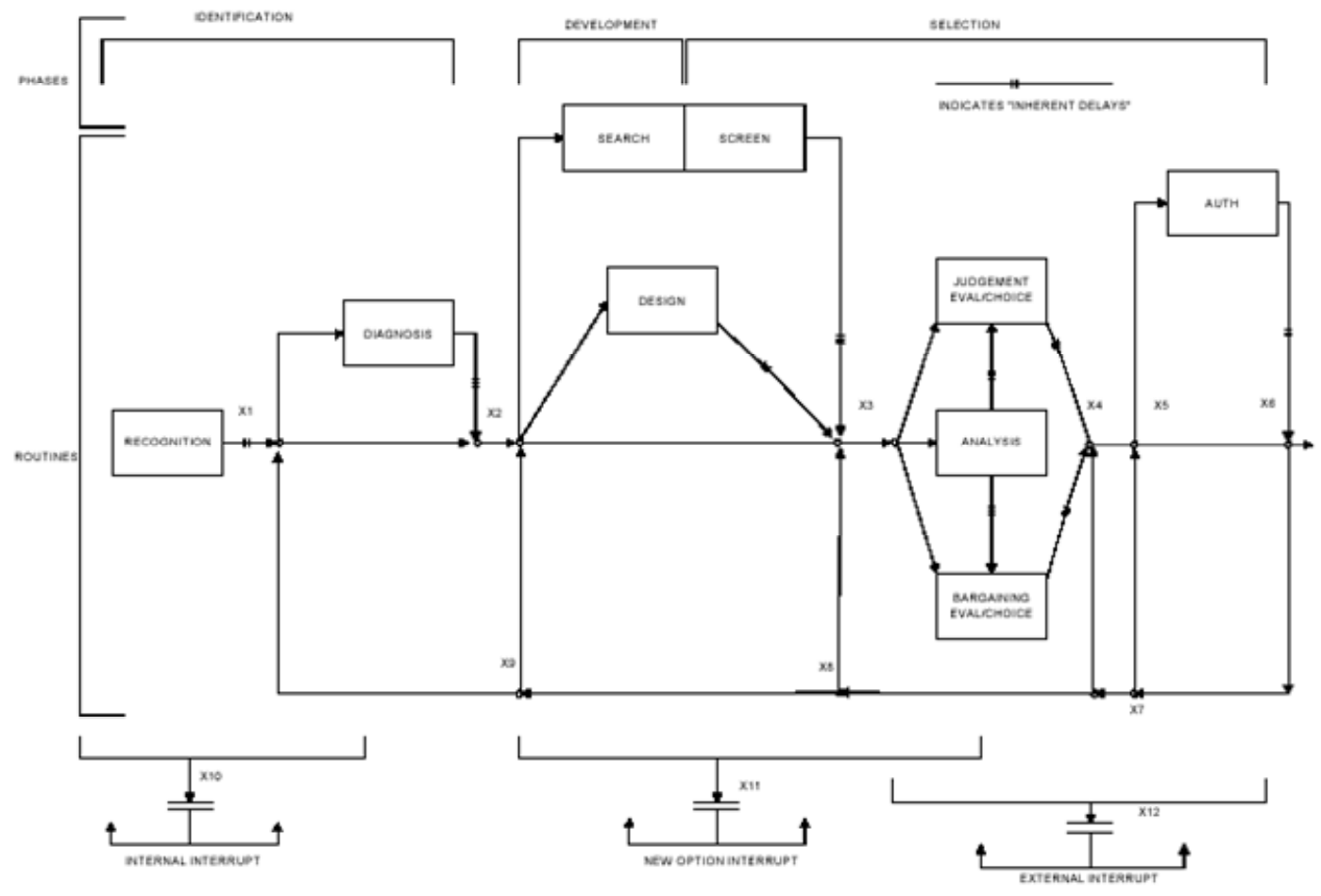

Figura 11: Modelo geral do processo decisório estratégico segundo Mintzberg et al FONTE: Mintzberg et al, 1976:266)

Na fase de identificação (identification phase), o estímulo que exige a atividade decisória é percebido e identificado; a rotina de reconhecimento (recognition routine) consiste em formular o problema a partir dos seus diversos elementos, que se apresentam de forma 
indefinida e difusa. Esta rotina é geralmente é seguida pela rotina de diagnóstico (diagnosis routine), um processo que pode se apresentar mais ou menos formalizado e que é caracterizado pela coleta e sistematização de informações sobre a situação-problema, inclusive a definição se esta constitui uma ameaça (crisis) ou oportunidade (opportunity). O autor do presente estudo entende que esta fase corresponde à descrição da situação atual e da situação desejada (ZACCARELLI, 2000), ou seja, à formulação do problema estratégico.

Em seguida, na visão dos autores (MINTZBERG et al, 1976), tem lugar a fase de desenvolvimento (development phase), que constitui "o coração do processo decisório": a geração de alternativas estratégicas. A rotina de busca (search routine) é a primeira desta fase e se caracteriza pela busca de possíveis soluções, para a qual os autores identificam quatro formas fundamentais: de memória (buscar situações semelhantes nos registros da organização), passiva, (esperar que uma solução seja apresentada, por exemplo, por fornecedores atuais ou potenciais), "armadilha" (trap, consiste em provocar o processo anterior) e ativa (pesquisar ativamente). Esta rotina pode ser substituída, complementada, ou combinada com a rotina de design (design routine), que consiste na elaboração de uma solução had hoc; eventualmente, esta pode assumir a forma de customização de soluções existentes (por exemplo, adaptações de equipamento ou sistemas), resultando em uma lista de alternativas estratégicas.

Os autores fazem referência à rotina de pré-seleção (screen routine) - que consiste na avaliação prévia de alternativas "mais no sentido de eliminar alternativas aparentemente inviáveis do que de identificar possíveis soluções" - localizada na interface entre a fase de desenvolvimento e a fase de seleção, que constitui a última fase do processo decisório. Além da rotina de pré-seleção, esta fase se estrutura em um conjunto de rotinas de avaliação- 
escolha (evalluation-choice) - que pode assumir as formas de julgamento (judgement, escolha individual), negociação (bargaining) e análise (analisys, por um ou mais especialistas) - seguida pela rotina de autorização, que consiste na validação externa da decisão e permissão para a sua implementação, nas organizações nas quais existe esta necessidade. Para os objetivos do presente estudo, esta fase pode ser considerada como única, considerando a situação de um sócio-gestor que responde ao mesmo tempo pela seleção, análise e escolha da alternativa.

O modelo processual de Mintzberg et al tem sido utilizado por diversos autores para análise de processos decisórios estratégicos, a exemplo de Khatri; Alvin (2000), que analisaram o papel da intuição nos PDE; Wilson (2001), que estudou a decisão de reestruturar uma empresa de serviços profissionais; Freitas; Macadar; Moscarola (1997), que pesquisaram instrumentos quanti-qualitativos para estudar o processo decisório; Li; Li; Dalgic (2004), em uma análise do processo de internacionalização de pequenas e médias empresas; e o estudo de Jocumse (2000) sobre decisões estratégicas em pequenas empresas.

Abordando a questão da decisão estratégica do ponto de vista da formação de estratégias, Barbero (2008) propõe um modelo conceitual considerando cinco dimensões, que correspondem a influências sobre os processos decisórios estratégicos (figura abaixo):

- Racionalidade e intuição: correspondem às características individuais dos processos mentais dos tomadores de decisão, discutidos nos itens acima;

- Deliberação e emergência: as decisões estratégicas são tomadas combinando processos formais de planejamento estratégico (estratégias deliberadas) com o processo informal de adaptação da organização às influências do ambiente (estratégias emergentes);

- Política e poder: as decisões estratégicas sofrem influências políticas, decorrentes do uso do poder pelos diversos grupos envolvidos; 
- Padrões do passado (cultura) x visão de futuro: a cultura da organização pode constituir importante influência sobre as decisões estratégicas, condicionando fortemente tanto a geração de alternativas quanto a sua avaliação;

- Discricionariedade e determinação ambiental: influências ambientais, em particular determinações legais e/ou de instâncias superiores podem limitar fortemente discricionariedade, ou seja, as opções estratégicas disponíveis para os decisores.

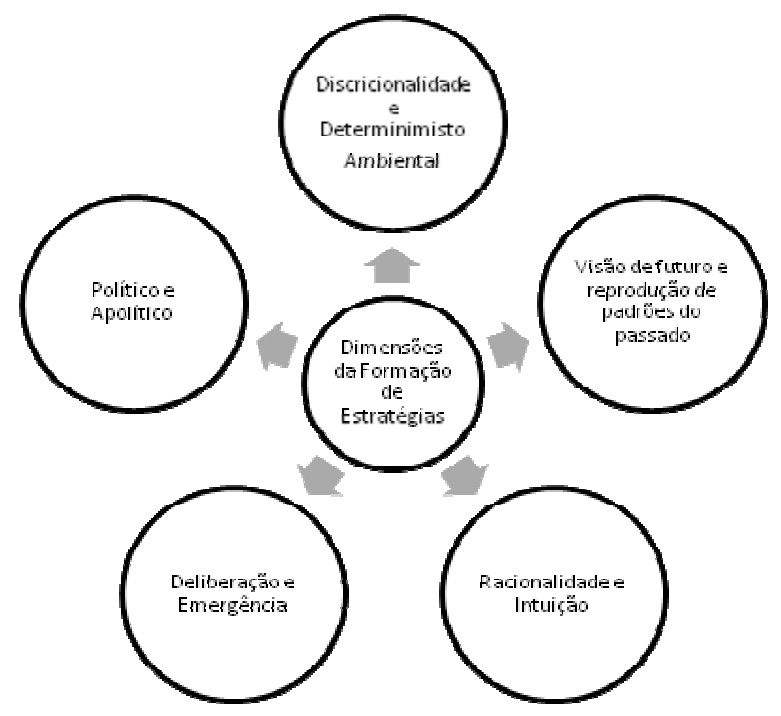

Figura 12: As cinco dimensões da formação de estratégias segundo Barbero Fonte: Barbero, 2008:13

O próprio autor sugere ser este um modelo genérico, com possibilidades de adaptações segundo o contexto da sua aplicação. Cabe destacar que a unidade de análise do estudo de Barbero (2008) é a organização, ou seja, as estratégias são entendidas como o resultado de um processo de formação mais amplo do que a formulação ou a concatenação de deliberada processos decisórios dos gestores, que segundo o autor constituem um aspecto particular do processo de formação de estratégias. A aplicação do modelo proposto por Barbero no contexto específico do processo decisório estratégico pelo sócio-gestor da pequena empresa será discutida mais adiante. Feitas estas considerações gerais sobre as decisões de caráter 
estratégico, no próximo item são discutidos aspectos do processo decisório estratégico em empresas de pequeno porte.

\subsection{Decisões Estratégicas em pequenas empresas}

Diversos autores, tais como Drucker (1999), têm destacado que as mudanças ocorridas desde o final do século $\mathrm{XX}$, causadas pela convergência de fatores sociais e políticos com os recentes progressos tecnológicos - constituindo a chamada nova economia, que Drucker denomina pós-capitalista - deslocaram definitivamente as fontes de vantagem competitiva da posse de ativos físicos e financeiros para a combinação inteligente de fatores intangíveis, entre os quais o conhecimento. Assim sendo, e após várias décadas de predominância da grande empresa industrial como paradigma de organização - ao lado das grandes estruturas de governo e dos conglomerados financeiros - a "nova economia" dos anos 1990 e 2000 parece fazer ressurgir a importância da pequena empresa.

Bortoli Neto (1980) afirma, baseado em Costa Gomes (1976), que a pequena empresa é fundamentalmente diferente da grande organização. Geralmente mais ágil e flexível do que grande empresa e apresentando "elevado espírito de iniciativa [e] grande capacidade de adaptação a mudanças ambientais" (BORTOLI NETO, 1980), a pequena empresa se apresenta como contraponto à expansão das grandes organizações. A este respeito, Julien (1997, apud ESCRIVÃO FILHO. 2006) considera os anos de 1990 como os anos "do renascimento das pequenas empresas", apontando como causas principais as mudanças econômicas e tecnológicas que levaram à rápida segmentação dos mercados ocorrida naquele período, combinada com fatores específicos tais como o esgotamento do modelo de emprego burocrático vitalício, levando muitos jovens profissionais a buscarem estabelecer os seus próprios negócios. 
Em acordo com Julien, Friedman (2005) chama a atenção para a difusão - acompanhada da rápida redução de preços e complexidade de uso - de produtos e serviços de comunicação e gerenciamento da informação, conferindo às pequenas empresas acesso ao mesmo tipo de ferramentas de gestão utilizadas pelas grandes corporações. De forma inédita na História das organizações, as pequenas empresas podem obter e gerenciar os ativos (agora intangíveis) que constituem as bases da competitividade - fundamentalmente, informação, conhecimento, competências individuais - utilizando-se de técnicas e ferramentas semelhantes àquelas utilizadas pelas grandes corporações. A realidade atual representa uma grande mudança em relação à situação descrita por Santos (1995):

As exigências de investimentos requeridas por qualquer processo de modernização empresarial são uma barreira que dificulta a ocorrência deste fenômeno no segmento das micro e pequenas empresas industriais. [...] uma micro e pequena empresa industrial enfrenta grandes dificuldades para ter acesso e adquirir novas tecnologias de gestão, de processo e de produto. (SANTOS, 1995:5).

Assim sendo, as pequenas empresas - em particular as indústrias de pequeno porte, EIPPs poderiam responder às demandas do atual ambiente de negócios, dinâmico e turbulento, de forma mais rápida e flexível do que as grandes organizações. Em particular no Brasil, o processo de abertura da economia ocorrido a partir do início dos anos 1990 exigiu a adaptação das empresas nacionais a um ambiente competitivo totalmente novo e com a abertura da economia brasileira ao processo de globalização e o acelerado avanço da informática e das telecomunicações, as empresas, em particular as pequenas indústrias, tiveram que passar por profundas mudanças.

Citando um estudo do SEBRAE (1994), Santos (1995) afirma que "com o recente processo de globalização da economia, o papel das pequenas empresas torna-se cada vez mais relevante". O autor se refere ao processo de reestruturação de grandes empresas, que ofereceu oportunidades para pequenas empresas "[...] se adequarem ao conceito de 'especialização 
flexível' $[\ldots]$ a grande empresa [...] através da parceria com uma ou várias pequenas empresas, consegue a flexibilidade estrutural e produtiva para adequar rapidamente seus produtos às demandas e mudanças constantes do mercado.”

Escrivão Filho (2006) questiona as tentativas de estabelecer uma classificação "quantitativa" do porte das empresas, em geral de autoria de organizações ligados de alguma forma ao Governo, tais como órgãos de fiscalização, SEBRAE, BNDES e outros. O autor aponta a dificuldade de estabelecer critérios quantitativos capazes de efetivamente distinguir "o pequeno do grande" e propõe que esta distinção seja estabelecida em termos qualitativos (quadro abaixo).

\section{Quadro 04 - Aspectos qualitativos característicos da pequena empresa} Fonte: Dutra e Gualiard (1984:125); Rattner (1985:25); Tafner (1995:9) apud Escrivão Filho, 2006:103

\begin{tabular}{|c|c|c|}
\hline Dutra e Gualiard (1984) & Ratner (1985) & Tafner (1995) \\
\hline $\begin{array}{l}\text { Apresentam condições particulares } \\
\text { de atividades reveladoras da } \\
\text { exigüidade do negócio }\end{array}$ & $\begin{array}{l}\text { Sistemas de organização e } \\
\text { administração } \\
\text { concentrados nas funções do } \\
\text { proprietário e familiares }\end{array}$ & $\begin{array}{l}\text { Posição central do empresário, } \\
\text { responsável pela condução das } \\
\text { atividades da empresa em todos os } \\
\text { seus aspectos }\end{array}$ \\
\hline $\begin{array}{l}\text { Não possuem administração } \\
\text { especializada fora da empresa }\end{array}$ & $\begin{array}{l}\text { Pouca especialização dos diversos } \\
\text { quadros administrativos }\end{array}$ & $\begin{array}{l}\text { Vínculo estreito entre a família e a } \\
\text { empresa }\end{array}$ \\
\hline Não têm produção em escala & $\begin{array}{l}\text { Relações internas e externas da em } \\
\text { pesa essencialmente pessoais }\end{array}$ & $\begin{array}{l}\text { Independência em relação a } \\
\text { grandes empresas }\end{array}$ \\
\hline $\begin{array}{l}\text { Usam trabalho próprio ou de } \\
\text { familiares }\end{array}$ & $\begin{array}{l}\text { Pouca qualificação do elemento } \\
\text { humano }\end{array}$ & $\begin{array}{l}\text { Procedimentos em geral intensivos } \\
\text { em MO, trabalhadores pouco } \\
\text { qualificados e em número reduzido }\end{array}$ \\
\hline Têm organizações rudimentares & $\begin{array}{l}\text { Dificuldades para obtenção de } \\
\text { financiamentos }\end{array}$ & $\begin{array}{l}\text { Disponibilidade reduzida de } \\
\text { recursos financeiros, dificuldade } \\
\text { de acesso ao mercado financeiro }\end{array}$ \\
\hline $\begin{array}{l}\text { Apresentam menos complexidade } \\
\text { do equipamento produtivo }\end{array}$ & Escassez de recursos próprios & $\begin{array}{l}\text { Identidade entre a propriedade e a } \\
\text { gestão cotidiana da empresa }\end{array}$ \\
\hline $\begin{array}{l}\text { São receptoras de MO liberada do } \\
\text { setor rural }\end{array}$ & $\begin{array}{l}\text { Inserção de subordinação e } \\
\text { dependência nos mercados de } \\
\text { insumos e produtos acabados }\end{array}$ & $\begin{array}{l}\text { Alta dependência quanto } \\
\text { fornecedores, clientes } \\
\text { concorrentes }\end{array}$ \\
\hline
\end{tabular}

A partir de uma ampla revisão de pesquisas sobre pequenas empresas, o autor defende as pesquisas longitudinais, baseadas no conceito de Ciclo de Desenvolvimento Organização (CDO), citando os trabalhos de Greiner (1998) e Adizes (2004) - que propuseram modelos 
para análise do CDO - além de Kimberly (1979, 1980), Quinn e Cameron (1983) e outros, sendo o mais recente Jawahar e McLaughin (2001). O autor conclui a revisão supracitada com uma crítica:

O que une estes autores? Uma crítica aos estudos administrativos voltados à empresa madura, entendase à grande empresa. Tudo, ou quase, que é ensinado nas faculdades de administração não serve para 98\% dos estabelecimentos empresariais do Brasil - de acordo com dados do IBGE - considerados os resultados empíricos que confirmam que conceitos e práticas administrativas são contingentes aos estágios do ciclo de desenvolvimento da organização. (ESCRIVÃO FILHO, 2006:117)

Além destes aspectos típicos de pequenas empresas, Corrêa (2007) destaca como uma característica destas últimas a ausência de sistemas - e até mesmo de critérios - de avaliação de desempenho, o que dificulta o estabelecimento de objetivos e políticas organizacionais. Quanto à comparação entre empresas grandes e pequenas, Borba; Martendal; Murcia (2004) sugerem ainda que as principais características que distinguem as empresas de pequeno porte das grandes podem ser resumidas:

Quadro 05: Principais características de pequenas x grandes empresas

\begin{tabular}{|l|l|l|}
\hline \multicolumn{1}{|c|}{ Característica } & \multicolumn{1}{c|}{ Grandes Empresas } & \multicolumn{1}{c|}{ Pequenas Empresas } \\
\hline Adaptabilidade & Pequena & Grande \\
\hline Administração & Profissional & Pessoal ou Familiar \\
\hline Decisão & Centralizada & Descentralizada \\
\hline Estrutura & Organizada & Informal \\
\hline Flexibilidade & Pequena & Grande \\
\hline Forma Jurídica & Sociedade Anônima & Limitada \\
\hline Idade Média & Alta & Pequena \\
\hline Níveis Hierárquicos & Muito & Poucos \\
\hline$N^{\circ}$ de Funcionários & Muitos & Poucos \\
\hline$N^{\circ}$ de Produtos & Grande & Pequeno \\
\hline Recursos Financeiros & Abundante & Escassos \\
\hline Sistema de Informação & Complexos, formalizados e & Simples, informais e manuais \\
& informatizados & \\
\hline Utilização de Tecnologia & Alta & Baixa (Artesanal) \\
\hline
\end{tabular}

Fonte: adaptado KASSAI (1997, p. 5)

Fonte: Borba; Martendal; Murcia (2004:9)

Já Bilessimo (2002) aponta os principais fatores de sucesso e os erros mais comuns de pequenas empresas: 
Quadro 06: Principais fatores de sucesso e erros mais comuns em pequenas empresas

\begin{tabular}{|c|c|}
\hline $\begin{array}{l}\text { Principais requisitos para um pequeno } \\
\text { negócio ser bem sucedido } \\
\text { (Ramiro; Carvalho, 2002) }\end{array}$ & $\begin{array}{l}\text { Dez erros gerenciais mais comuns } \\
\text { cometidos por gestores de MPEs } \\
\text { (SOUZA, 2000) }\end{array}$ \\
\hline $\begin{array}{l}\text { - } \quad \text { conhecer o mercado em que pretende atuar; } \\
\text { - } \quad \text { planejar gastos e estratégias de marketing; } \\
\text { - } \quad \text { nanhecer o perfil do cliente; } \\
\text { sempre informar o concorrente, mantendo-se } \\
\text { movimentos; } \\
\text { - ter uma experiência profissional anterior na } \\
\text { área, que ajude na condução do seu } \\
\text { empreendimento; } \\
\text { investir constantemente no negócio, muitas } \\
\text { vezes em detrimento da aquisição de bens } \\
\text { pessoais. }\end{array}$ & $\begin{array}{l}\text { - } \quad \text { ser centralizador em demasia; } \\
\text { - } \quad \text { usar mal o tempo; } \\
\text { - } \quad \text { pensar visa na emprestada olhando negócio; } \\
\text { - } \quad \text { achar que pode ter sucesso sozinho } \\
\text { - } \quad \text { misticar muitas horas interesses da firma e familiares } \\
\text { - desviar atenção, tempo, esforço e dedicação } \\
\text { - do foco principal de seu negócio; } \\
\text { - } \quad \text { imaginar que já sabe tudo; } \\
\text { sem paixão. }\end{array}$ \\
\hline
\end{tabular}

Fonte: Borba; Martendal; Murcia (2004:9), apud Bilessimo (2002)

No que tange ao processo decisório estratégico, Almeida (2006) destaca que a gestão destas empresas é fortemente marcada pelo estilo pessoal de seus sócios-gestores, sendo provavelmente este o aspecto mais peculiar do pensamento estratégico na pequena empresa. Escrivão Filho (2006) aponta que os resultados de diversos autores sobre o tema do planejamento nas pequenas empresas (Robinson, 1984; O’Neill et al. 1987) indicam que a atividade de planejamento na pequena empresa apresenta-se "[...] menos formal do que o encontrado em grandes empresas". Por outro lado, cita Drucker (1981): “o maior problema da pequena empresa [...] é ser pequena demais para sustentar a administração de que precisa", o que vem ao encontro da premissa de que na pequena empresa o sócio-gestor geralmente é responsável por todo o processo decisório estratégico; em acordo ainda com Bortoli Neto Bortoli Neto (1980, 1994), que afirma que a PME reflete, em grande parte, a imagem pessoal e as características da personalidade de seus proprietários.

Escrivão Filho (2006) cita ainda Leone (1999), que identifica as especificidades da pequena empresa em termos de três variáveis principais: Especificidades organizacionais (a pequena empresa apresenta-se geralmente centralizada), decisionais (decisões marcadas pelo sistema 
de valores do proprietário e baseadas principalmente na experiência, julgamentos e intuição do mesmo) e individuais (papel predominante de um indivíduo na empresa, cujo funcionamento depende quase totalmente dele). Novamente, a literatura parece sustentar a premissa de que o processo decisório estratégico na pequena empresa seja responsabilidade exclusiva do sócio gestor, sendo, portanto importante analisar a influência das suas características pessoais sobre o processo decisório.

Segundo Gimenez (1998), as abordagens encontradas normalmente na literatura sobre o processo estratégico não levam em consideração a influência das características pessoais dos administradores sobre as organizações. Assim sendo, a maneira que o empreendedor percebe o ambiente - o seu estilo cognitivo - pode ter grande influência sobre as decisões estratégicas. Estilo cognitivo tem sido definido como "diferenças individuais estáveis na preferência por modos de obter, de organizar e utilizar a informação na tomada de decisões" (KIRTON, 1976, apud GIMENEZ, 1998).

Quadro 07: Estilos cognitivos segundo Kirton

\begin{tabular}{|c|c|c|c|}
\hline Estilo & Comportamento & Preferência & Características \\
\hline Adaptativo & $\begin{array}{c}\text { Resolver problemas } \\
\text { utilizando métodos } \\
\text { conhecidos }\end{array}$ & Fazer melhor & $\begin{array}{c}\text { precisão, eficiência, disciplina } \\
\text { e atenção às normas }\end{array}$ \\
\hline Inovativo & $\begin{array}{c}\text { Buscar novas } \\
\text { abordagens }\end{array}$ & Fazer diferente & $\begin{array}{c}\text { indisciplinado, desafiador de } \\
\text { regras }\end{array}$ \\
\hline
\end{tabular}

Fonte: adaptado pelo autor (GIMENEZ, 1998)

Cognição se refere à forma como as pessoas adquirem e usam conhecimento. É importante distinguir estilo cognitivo - a forma de processar informações - de habilidade cognitiva, que é capacidade de processar informações, esta última sujeita às distorções provocadas pelos vieses cognitivos discutidos anteriormente. $\mathrm{O}$ autor propõe um modelo para avaliar estilo cognitivo, a Teoria da Adaptação-Inovação: 
Kirton (1976) propôs que os indivíduos adotam estilos preferidos [...] com dois pólos distintos de tomada de decisão e solução de problemas, indicando uma preferência por fazer as coisas melhor ou fazer as coisas diferentemente. [...] denominados preferências de comportamento adaptativo ou inovativo, respectivamente. Indivíduos que têm estilo adaptativo [...] tentam resolver problemas através da aplicação de soluções que derivam de métodos conhecidos e já testados. O estilo inovador, por outro lado, é caracterizado como sendo indisciplinado, desafiador de regras, e que procura maneiras novas e diferentes de resolver problemas. (GIMENEZ, 1998).

Embora o modelo de PORTER (1986) das estratégias genéricas de custo, diferenciação e foco seja muito difundido e utilizado, este é concebido a partir da análise de setores industriais oligopolizados e em geral não se adapta bem à análise de pequenas empresas, que na prática adotam quase obrigatoriamente a estratégia de foco. Por outro lado, a estratégia genérica de foco admite duas amplas categorias - liderança relativa em custos e diferenciação - cada uma permitindo numerosas variantes de implementação, o que levanta a necessidade de uma taxonomia de estratégias mais adequada à análise de setores caracterizados pela presença de um grande número de competidores de pequeno porte.

Quadro 08: Categorias Estratégicas de Milles e Snow

\begin{tabular}{|c|l|}
\hline Categoria & \multicolumn{1}{|c|}{ Descrição } \\
\hline $\begin{array}{c}\text { Estratégia } \\
\text { defensiva }\end{array}$ & $\begin{array}{l}\text { Uma empresa seguindo esta estratégia procura localizar e manter uma linha de } \\
\text { produtos/serviços relativamente estável. Seu foco concentra-se em uma gama de } \\
\text { produtos/serviços mais limitada do que seus concorrentes e tenta proteger seu domínio } \\
\text { através da oferta de produtos com melhor qualidade, serviços superiores e/ou menores } \\
\text { preços. Não procura estar entre os líderes da indústria, restringindo-se àquilo que sabe fazer } \\
\text { tão bem ou melhor que qualquer um. }\end{array}$ \\
\hline $\begin{array}{c}\text { Estratégia } \\
\text { prospectora }\end{array}$ & $\begin{array}{l}\text { Uma empresa que adota esta estratégia está continuamente ampliando sua linha de } \\
\text { produtos/serviços. Enfatiza a importância de oferecer novos produtos/serviços em uma área } \\
\text { de mercado relativamente mais ampla. Valoriza ser uma das primeiras a oferecer novos } \\
\text { produtos, mesmo que todos os esforços não se mostrem altamente lucrativos. }\end{array}$ \\
\hline $\begin{array}{c}\text { Estratégia } \\
\text { analítica }\end{array}$ & $\begin{array}{l}\text { Uma empresa que segue esta estratégia tenta manter uma linha limitada de } \\
\text { produtos/serviços relativamente estável e ao mesmo tempo tenta adicionar um ou mais } \\
\text { novos produtos/serviços que foram bem sucedidos em outras empresas do setor. Em muitos } \\
\text { aspectos é uma posição intermediária entre as estratégias defensiva e prospectora. }\end{array}$ \\
\hline $\begin{array}{c}\text { Estratégia } \\
\text { reativa }\end{array}$ & $\begin{array}{l}\text { A firma que adota uma estratégia reativa exibe um comportamento mais inconsistente do } \\
\text { que os outros tipos. É uma espécie de não-estratégia. Não arrisca em novos } \\
\text { produtos/serviços a não ser quando ameaçada por competidores. A abordagem típica é } \\
\text { "esperar para ver" e responder somente quando forçada por pressões competitivas para } \\
\text { evitar a perda de clientes importantes e/ou manter lucratividade. }\end{array}$ \\
\hline
\end{tabular}

Fonte: extraído de GIMENEZ (1998)

Também parece razoável supor que o estilo cognitivo (ver acima) do gestor influencie suas escolhas estratégicas, ou seja, o seu "estilo estratégico", que pode ser bem identificado nas 
categorias estratégicas propostas por Miles e Snow (1978, apud GIMENEZ et al, 1999). A taxonomia proposta por Miles e Snow "tem sido amplamente testada nos mais diversos ambientes empresariais" (SHORTELL; ZAJAC, 1990; JAMES; HATTEN, 1994, apud GIMENEZ et al, 1999) e sua aplicação independe do porte da empresa. O modelo de Miles e Snow identifica quatro tipos ou categorias básicas de estratégia. Duas constituem um contraste bem definido: estratégia defensiva e estratégia prospectora. A estratégia defensiva se caracteriza por definições estreitas de produtos e mercados e ênfase na eficiência. Já a estratégia prospectora consiste na busca da inovação em produtos, mercados e processos e ênfase na eficácia.

Uma terceira categoria, que pode ser vista como híbrida entre as anteriores, é denominada estratégia analítica e consiste na combinação entre um núcleo estável de produtos, mercados e processos e áreas de negócios tratados de forma prospectora. Finalmente, uma quarta categoria seria definida pela prática de simplesmente reagir às demandas do ambiente, sem apresentar qualquer relação perceptível entre estratégia/estrutura e ambiente, denominada estratégia reativa. Embora esta última possa ser considerada como uma "não-estratégia", talvez constitua a única alternativa possível para empresas muito pequenas e/ou novas, sendo que da seqüência de interações poderia emergir a estratégia "definitiva" da empresa, na forma de um padrão geral de decisões estratégicas.

Lembrando que uma das características da pequena empresa é a sua dependência em relação a outras organizações, em geral de maior porte tais como fornecedores, clientes e outras, fazse necessário considerar, além das características cognitivas e comportamentais do gestor responsável pela tomada de decisões estratégicas, as influências referentes ao ambiente no qual esta está inserida. Segundo Almeida (2006), ambiente deve ser entendido como o 
conjunto de fatores que não podem ser influenciados por decisões ou ações gerenciais. Este conjunto de fatores pode ser dividido em dois subconjuntos, o ambiente interno e o ambiente externo. Por ambiente interno entendem-se os aspectos inerentes à empresa ou mais especificamente às pessoas que a constituem, como por exemplo, os valores dos sócios; e por ambiente externo, os fatores presentes no setor e mercados de atuação ou na esfera jurídico-legal e social nas quais a empresa está inserida. Esta discussão, juntamente com a análise das características das EIPPs paulistas apresentada a seguir, constitui um aspecto central da formulação do modelo teórico do estudo, que será apresentado ao final deste capítulo.

\subsection{As EIPPs paulistas}

Estudos do IBGE (2003), Escrivão Filho (2006) e do SEBRAE (2008) indicam que existem no Brasil pouco mais de cinco milhões de empresas, das quais $98 \%$ são micro e pequenas empresas (MPEs), que respondem por mais de dois terços das ocupações do setor privado. No estado de São Paulo existem 1,3 milhão de MPEs, sendo que 43\% atuam no comércio, 31\% em serviços, $14 \%$ na agropecuária e $12 \%$, na indústria, levando a uma estimativa de 156.000 MPEs industriais no estado de São Paulo. Estas respondem por $60 \%$ dos postos de trabalho e cerca de $40 \%$ do PIB industrial do estado, que por sua vez constitui cerca de $1 / 3$ do PIB industrial brasileiro, o que indica uma estimativa por volta de $12 \%$ do PIB industrial nacional e $18 \%$ dos empregos industriais do país a cargo das EIPPs paulistas.

Considerando a discussão anterior, mostra-se importante para os objetivos do presente estudo analisar as EIPPs paulistas no contexto da globalização dos negócios. Deste ponto de vista, um panorama amplo da inserção da indústria paulista no mercado globalizado é oferecido por Britto (2004), a partir de dados da Federação das Indústrias do Estado de São Paulo (FIESP), 
que indicavam um universo de 16.384 empresas industriais paulistas associadas à FIESP em 2002, sendo 1253 micro-empresas, com menos de dez pessoas empregadas; das restantes $14.931(77 \%)$ poderiam ser consideradas de pequeno porte, resultando 11.496 EIPPs associadas à FIESP nesse ano.

A amostra analisada na pesquisa em questão foi colhida excluindo as "super grandes" e as micro-empresas (menos de dez colaboradores); foi composta de 393 indústrias, das quais $75 \%$ empresas de pequeno porte, $21 \%$ de médio porte e $4 \%$ de grande porte. As empresas com participação de capital estrangeiro representaram apenas 10\% da amostra, ou seja, $90 \%$ das empresas analisadas apresentavam capital exclusivamente nacional. $\mathrm{Na}$ região metropolitana (Grande São Paulo) foram colhidas 52\% das empresas da amostra, na região Leste, $23 \%$, na região Norte, $8 \%$, na região Sul, 7\%, e nas regiões Oeste e Centro, $5 \%$, assim distribuídas pelos diversos ramos industriais:

Tabela 01 - Indústrias pesquisadas por ramo industrial

\begin{tabular}{|l|c|c|}
\hline \multicolumn{1}{|c|}{ Ramo } & Freqüência & Percentual \\
\hline 1- Alimentícia E De Bebidas & 34 & 8.65 \\
\hline 2- Automobilística e Fornecedores & 22 & 5.60 \\
\hline 3- Fab Equips Med-Hosp & 12 & 3.05 \\
\hline 4- Fab Maqs Escritório E Equips De Informática E Automação & 7 & 1.78 \\
\hline 5- Fab Maqs, Aparelhos Materiais Elétricos & 19 & 4.83 \\
\hline 6- Fab Material Eletrônico, Aparelhos, Equips Comunic & 11 & 2.80 \\
\hline 7- Fab Prods Metal - Exclusive Maquinas E Equipamento & 43 & 10.94 \\
\hline 8- Fabricação De Artigos De Borracha & 9 & 2.29 \\
\hline 9- Fabricação De Artigos De Plástico & 38 & 9.67 \\
\hline 10- Fabricação De Calcados & 8 & 2.04 \\
\hline 11- Fabricação De Celulose, Papel E Produtos De Papelão & 9 & 2.29 \\
\hline 12- Fabricação De Maquinas E Equipamentos & 44 & 11.20 \\
\hline 13- Fabricação De Moveis E Acessórios & 23 & 5.85 \\
\hline 14- Fabricação De Produtos De Madeira & 7 & 1.78 \\
\hline 15- Fabricação De Produtos De Minerais Não-Metálico & 13 & 3.31 \\
\hline 16- Farmacêutica E Serviços Em Saúde & 5 & 1.27 \\
\hline 17- Indústria Química, Produtos Químicos E Petroquímica & 31 & 7.89 \\
\hline 18- Metalurgia & 19 & 4.83 \\
\hline 19- Outros & 7 & 1.78 \\
\hline 20- Têxtil, Artigos Do Vestuário E Acessórios & 32 & 8.14 \\
\hline TOTAIS & $\mathbf{3 9 3}$ & $\mathbf{1 0 0}$ \\
\hline
\end{tabular}

Fonte: Britto (2004:113) 
A pesquisa analisou, entre outros aspectos, a prática da exportação na indústria paulista, tendo verificado que das 393 indústrias pesquisadas, 57\% não exportavam, 21\% exportavam até $5 \%$ do faturamento total da empresa, $11 \%$ exportavam de $5 \%$ a $15 \%$ e $11 \%$ exportam mais de $15 \%$ de seu faturamento. O autor aborda tanto a questão da motivação (por que e para que exportar?) quanto a forma (planejada? reativa?) da decisão e a sua implementação. Para tanto, analisou o conceito de prontidão p/ exportar (CAVUSGIL, 1998, apud BRITTO, 2004), utilizando a metodologia e o software CORE (idem) para avaliar a capacidade da indústria paulista de competir no contexto global.

O Core avalia as empresas e sua principal linha de produtos com base em um conjunto de perguntas de múltipla escolha, à qual estão associados pontos de acordo com a resposta oferecida, o que caracteriza a pesquisa como sendo de tipo Estruturada com questões Fechadas (BABBIE, 2001). A somatória dos pontos das diferentes questões indicam um melhor ou pior grau de preparo da empresa ou de sua principal linha de produtos para enfrentar a competição no comércio global. Os critérios para definir as respostas e suas respectivas interpretações foram baseados em ampla revisão da literatura pelos elaboradores deste Software, sendo que se busca, na própria revisão bibliográfica, identificar as principais evidências empíricas ligadas às questões aplicadas. A empresa não é avaliada apenas na sua totalidade. As perguntas são agrupadas em seis diferentes dimensões, cujos resultados são avaliados separadamente. As dimensões são: Capacidades Competitivas no Mercado Doméstico; Motivação para Internacionalizar-se; Compromisso dos proprietários e da alta gestão; Conhecimentos, técnicas e recursos; Experiência e treinamento; e, finalmente, Prontidão do produto para a exportação. Os resultados obtidos pela empresa (baixo, médio ou alto grau de preparo para a exportação), cotejados com os resultados obtidos pela sua principal linha de produtos (baixo, médio ou alto grau de preparo para a exportação), produzem uma matriz de 9 células. De acordo com a posição em que a empresa se encontra nessa matriz, é recomendada uma estratégia de internacionalização específica. (BRITTO, 2004:105-106).

Esta análise se reveste de particular importância para o presente estudo, dado que a decisão de exportar constitui uma decisão estratégica para a empresa - grande incerteza, alto risco, forte influência sobre o futuro da empresa e difícil reversibilidade.

Os resultados da pesquisa indicaram que, de forma geral, estas indústrias apresentavam deficiências quanto à sua competitividade, mormente quanto ao aspecto da sua Prontidão Organizacional, representada pelo conjunto das cinco primeiras dimensões supracitadas (Capacidades Competitivas no Mercado Doméstico; Motivação para Internacionalizar-se; 
Compromisso dos Proprietários e da Alta Gestão; Conhecimentos, Técnicas e Recursos; Experiência e Treinamento).

Segundo a metodologia utilizada pelo CORE, a competitividade das indústrias segue a classificação de Baixa, Média e Alta. Para pontuações abaixo de 50 classifica-se a empresa como sendo de Baixa competitividade, para o intervalo entre 50 e 80 classifica-se como sendo de Média competitividade e acima de 80 pontos como sendo de Alta competitividade. O escore geral médio (OVERALL) da amostra foi de 49,6 o que classifica a indústria paulista no limite entre as faixas de Baixa e Média Prontidão para Exportação quando medida neste instrumento de avaliação.

Quanto às dimensões "Competitividade no mercado brasileiro"; "Motivação para internacionalização" e "Prontidão do produto" a indústria paulista está, de maneira geral, com média prontidão para exportação. Logo se observa que a motivação e o desenvolvimento de produtos devem ser melhorados, mas não são as maiores deficiências da indústria paulista. Para as dimensões "Comprometimento dos donos e da alta gerência"; "Habilidades, conhecimentos e recursos" e "Experiência e treinamento" a indústria paulista apresenta os seus piores resultados, indicando que necessita de esforços nessas áreas para melhorar a sua competitividade. (BRITTO, 2004:115-116, grifo deste autor).

Em outras palavras, as deficiências que mais comprometem a competitividade das EIPPs paulistas parecem concentrar-se não nos seus produtos, mas sim em seus processos administrativos, entre os quais, presumivelmente, o processo decisório estratégico.

A formação de estratégias - que engloba o processo decisório estratégico - na indústria paulista é o tema da pesquisa de Barbero (2008), que analisou 354 empresas industriais situadas no estado de São Paulo, sendo 58 microempresas; 110 pequenas empresas; 69 médias empresas e 116 grandes empresas. A partir do modelo teórico descrito no item 2.3 deste estudo - no qual a formação de estratégias é decomposta em cinco dimensões - o estudo indica que “[...] muitas das estratégias realizadas nas empresas não são previamente concebidas.” (BARBERO, 2008, itálico no original); “[...] as organizações de menor porte tendem a possuir estratégias mais emergentes $[\ldots]$ As pequenas empresas possuem 
relativamente menos processos de planejamento estratégico formal que as grandes [...]" (idem, negrito no original).

O autor também destaca as peculiaridades das empresas de menor porte quanto à questão da racionalidade x intuição, indicando que embora "No que tange à racionalidade-intuição os respondentes indicaram que suas decisões são preponderantemente racionais [...]”, as respostas dos gestores das empresas de menor porte indicam uma predominância de processos racionais bastante mais fraca do que os seus pares das grandes empresas. Quanto à questão de se as indústrias paulistas apresentam estratégias mais padronizadas culturalmente ou mais voltadas para os sinais do futuro, “[...] mais uma vez, há diferenças importantes entre as médias das microempresas e das organizações de maior porte [...]", com as primeiras mostrando uma maior tendência a estratégias condicionadas pelos padrões do passado.

De forma geral, os resultados de Barbero (2008) parecem estar em acordo com as principais indicações da discussão teórica desenvolvida acima, ou seja:

- as pequenas empresas apresentam peculiaridades quanto às características do PDE;

- as decisões estratégicas são tomadas predominantemente pelo principal executivo;

- o PDE combina elementos de racionalidade e intuição;

No item 4.1 do presente estudo, serão retomados alguns aspectos dessas pesquisas, enfocando especificamente as EIPPs analisadas.

\subsection{Modelo teórico do estudo}

O processo decisório estratégico provavelmente venha recebendo menos atenção dos pesquisadores do que seria de desejar e certamente o comportamento do administrador da 
pequena empresa tem sido menos estudado do que o executivo da grande organização. Assim sendo, o objetivo do presente estudo é oferecer contribuições para o conhecimento teórico sobre o processo decisório estratégico, em especial no caso de sócios-gestores de empresas industriais de pequeno porte (EIPPs).

O presente estudo parte de um modelo preliminar, sugerido pela combinação das principais visões teóricas discutidas acima: a visão do gestor como mediador entre "a sua unidade (no caso, a empresa) e o ambiente", com destaque para o seu papel fundamental de tomador de decisão (MINTZBERG, 1973); a definição de "ambiente" como o conjunto da fatores que não podem ser alterados por ações do gestor (ALMEIDA, 2006); o conceito de decisão estratégica como a solução de um problema de passagem (ZACCARELLI, 2000); o modelo processual descritivo do processo decisório estratégico de Mintzberg et al (1976); e o modelo das cinco dimensões da formação de estratégias proposto por Barbero (2008), adaptado para a análise do processo decisório estratégico do sócio-gestor da pequena empresa industrial.

Em acordo com Barbero (2008), o autor do presente estudo entende que o processo decisório estratégico constitui um aspecto particular da formação de estratégias. No contexto específico da pequena empresa, assume-se no presente estudo que o processo decisório estratégico mostra-se fundamentalmente individual, ou seja, a unidade de análise é o sócio-gestor da empresa. Neste contexto e deste ponto de vista específico, o autor do presente estudo entende que as cinco dimensões propostas por Barbero podem ser reinterpretadas em um arranjo tridimensional de influências sobre o processo de tomada da decisão estratégica.

Uma vez que se deseja estudar o processo de decisão do sócio gestor da pequena empresa; que este processo é entendido como fundamentalmente individual; que a estrutura muito 
enxuta não favorece a formação de grupos de influência; e que a escassez de recursos limita as possibilidades de jogos de poder, os aspectos ligados às dimensões das influências da política e do poder, ao processo de emergência e a determinação ambiental podem ser unificados em uma dimensão única, o Ambiente.

Conforme discutido acima, o processo decisório estratégico na EIPP é considerado neste estudo como sendo fundamentalmente individual, fortemente condicionado pelas restrições do ambiente (interno e externo) e pelas características pessoais do gestor, que se manifestam fundamentalmente em aspectos cognitivos (racionalidade x intuição) e atitudinais (padrões do passado $\mathrm{x}$ visão do futuro). Este jogo de influências e a sua representação sintética são mostrados na figura abaixo e discutidos a seguir.

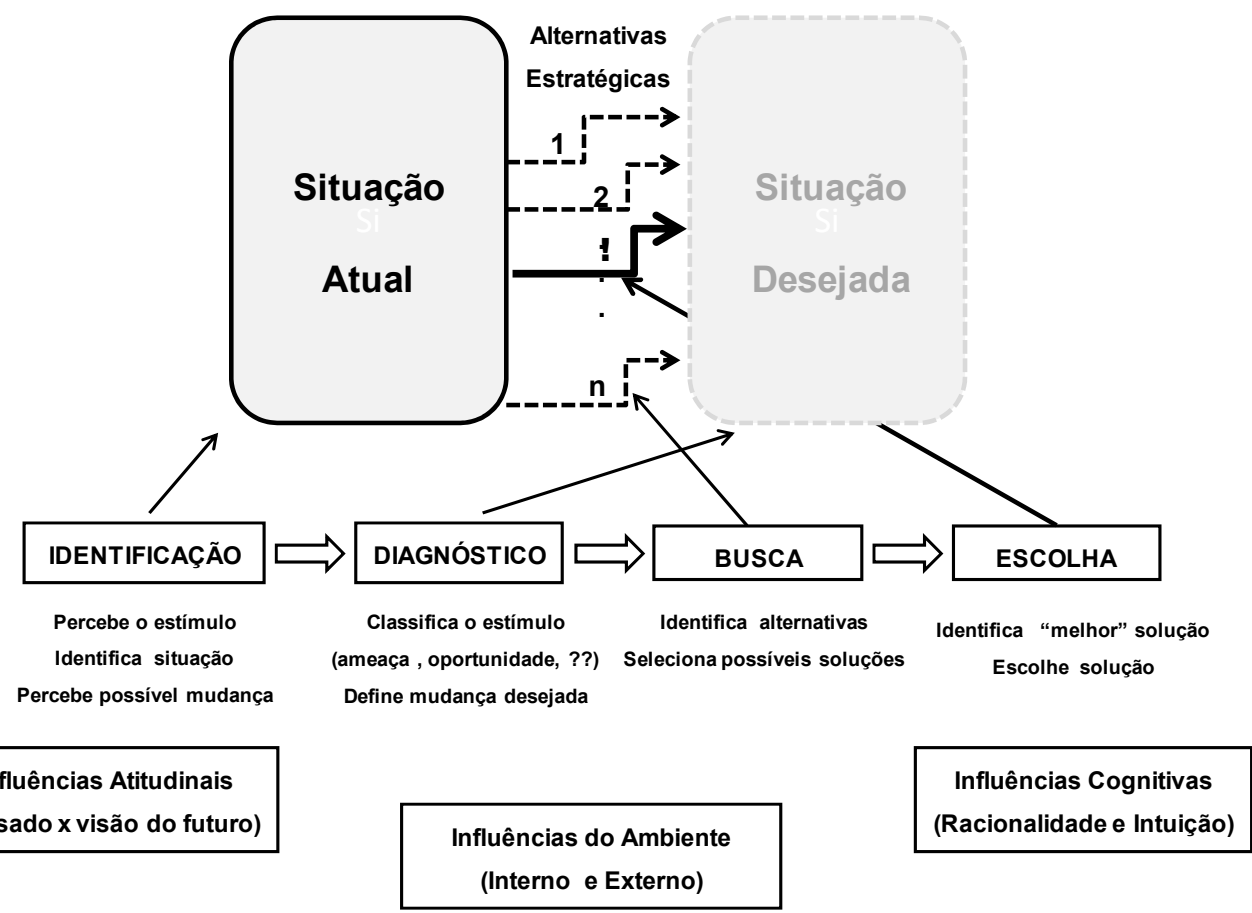

Figura13: Diretriz Teórica ampliada Fonte: elaborada pelo autor 
O sócio-gestor da pequena empresa desempenha, de forma semelhante ao executivo da grande organização, o papel fundamental de mediador entre a empresa e o seu ambiente (MINTZBERG, 1973). Em outras palavras, é possível afirmar que um aspecto fundamental do seu processo decisório consiste em identificar, analisar e equilibrar as influências do ambiente interno e do ambiente externo da empresa, lembrando que estas, por definição (ALMEIDA, 2006) não podem ser alteradas por estas decisões. Portanto, o ambiente da empresa - conjunto dos fatores que influenciam a empresa e não podem ser influenciados por ações gerenciais - constitui uma dimensão da decisão, que pode ser representada por um eixo no qual se alinham as influências do ambiente interno (valores, cultura) e ambiente externo (agentes econômicos), que pode ser denominado eixo ambiental.

Adotando a visão bipolar proposta por Barbero (2008), entende-se que cada processo envolvido na formação de estratégias pode posicionar-se ao longo de um continuum representado por dois extremos, (por exemplo, uma decisão que se posiciona entre os extremos teóricos da racionalidade absoluta e da pura intuição, na prática combinando elementos de ambas e com predominância relativa de um ou outro aspecto). Considerando a questão das limitações cognitivas (racionalidade limitada) do tomador de decisão, o autor do presente estudo entende que, durante o processo decisório estratégico, o decisor levará em conta uma combinação aspectos do ambiente interno e externo, com provável predominância de um ou outro. Em outras palavras, o tomador de decisão provavelmente se mostrará mais propenso a priorizar aspectos internos (os valores da empresa, por exemplo) e deixar em segundo plano os externos (considerações quanto à evolução do mercado e da concorrência) ou vice-versa, conforme a sua percepção pessoal da importância relativa destes fatores. 
Por outro lado, como discutido acima, o processo decisório estratégico combina elementos de racionalidade e de intuição. Racionalidade tem relação com o universo intelectual do decisor, sua capacidade de abstração e análise, construídas fundamentalmente pelo processo de educação formal. Intuição se refere fundamentalmente a aspectos inconscientes e semiconscientes, construídos ao longo vida emocional do gestor e que constituem a sua "prisão psíquica" (MORGAN, 1996). Aparentemente, da interação destes aspectos resultaria o estilo cognitivo do gestor (KIRTON, 1976, apud GIMENEZ, 1998). Parece então configurar-se um segundo "eixo", que se poderia chamar de eixo cognitivo. De forma análoga à discussão anterior, ao longo deste "eixo" se alinham as influências cognitivas, em um contínuo entre a racionalidade (processo mentais explícitos, conscientes, do tipo hesitação-escolha) e intuição (processos mentais semi-conscientes e inconscientes, do tipo estímulo-resposta).

Finalmente, ainda conforme a orientação proposta por Barbero (2008), é preciso analisar as influências antagônicas dos padrões do passado, (do decisor, da empresa, do ambiente) e da visão de futuro, estabelecendo um terceiro "eixo", que se pode denominar eixo atitudinal. Esta dimensão de análise do processo decisório estratégico pode ser entendida como um contínuo entre duas crenças fundamentais: em um extremo, a idéia de que o futuro deverá predominantemente repetir o passado, o que implica na influência predominante dos padrões do passado (cultura, valores) sobre as decisões estratégicas; no extremo oposto, a convicção que o futuro deverá mostrar-se fundamentalmente diferente do passado, levando a decisões mais influenciadas pela visão de futuro do tomador de decisão. Ainda de forma análoga às duas outras dimensões consideradas, entende-se que as decisões "reais" deverão combinar elementos referentes a ambos os pólos, com a possível predominância de um deles configurando decisões mais "conservadoras" (passado) ou "arrojadas" (futuro). 
Vale notar (figura abaixo) que estes "eixos" determinam "planos de análise"; por exemplo, a cultura (predominância de padrões do passado) pode referir-se tanto ao ambiente interno (na sua acepção mais usual) quanto ao ambiente externo (práticas de mercado, políticas de governo etc.). Assim, uma determinada decisão estratégica poderia mostrar-se, por exemplo, como o resultado da análise racional de cenários futuros possíveis para o ambiente externo, todavia fortemente influenciada por aspectos culturais e padrões passados (ambiente interno) da empresa.

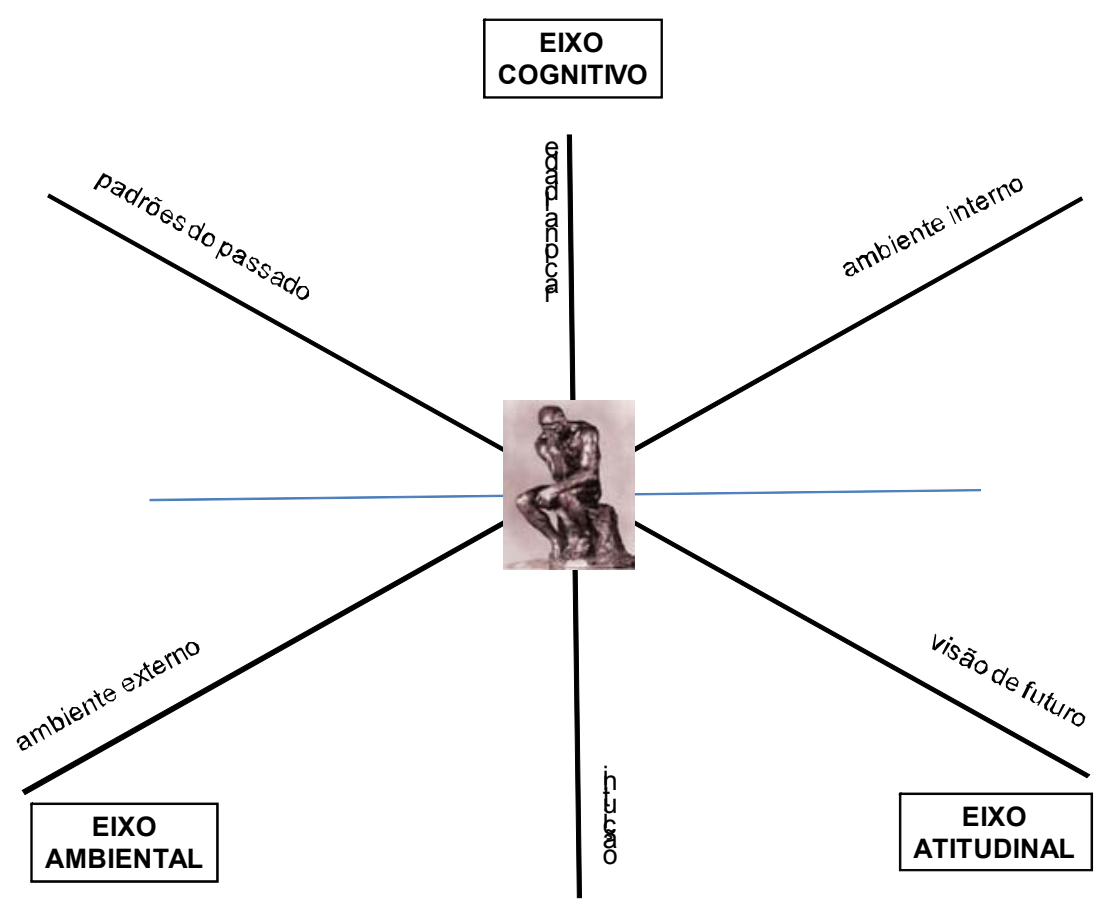

Figura 14: Modelo Teórico do estudo: Modelo tridimensional da decisão estratégica Fonte: elaborado pelo autor

A fase da campo do presente estudo estrutura-se a partir destas reflexões. No próximo capítulo, são discutidos os princípios e métodos empregados no estudo, com ênfase nas suas características, possibilidades e limitações. 


\section{METODOLOGIA}

Entende-se por pesquisa científica a investigação sistemática de um fenômeno determinado, utilizando o método científico. (LAKATOS E MARCONI, 1991). Na pesquisa em Administração, que geralmente tem por objetivo analisar relações entre fenômenos de forma a orientar ações, tem sido mais empregado o método hipotético-dedutivo, preconizado por Popper. Uma descrição sucinta deste método (LAKATOS E MARCONI, 1991) consiste em:

- no âmbito de um tema sobre o qual já existe algum conhecimento estabelecido, o pesquisador identifica uma lacuna que vem a constituir a questão que a pesquisa se propõe a responder, ou seja, formula uma questão de pesquisa;

- o pesquisador propõe uma resposta tentativa à questão proposta, formulando uma (ou mais) hipótese de pesquisa;

- o próximo passo do pesquisador consiste em planejar a verificação da validade da(s) hipóteses(s), o que constitui o plano de prova;

- o plano de prova se estrutura de forma geral (1) na construção de variáveis, que constituem o elo de ligação entre a realidade observada e as hipóteses, (2) na coleta de dados, utilizando metodologias que garantam a sua validade e confiabilidade para o escopo da pesquisa e (3) na análise dos dados, utilizando ou não ferramentas estatísticas, conforme a natureza da pesquisa;

- de acordo com os resultados da análise, a hipótese é corroborada, ou seja, aceita pelo menos provisoriamente como uma resposta válida à questão de pesquisa, ou refutada.

Já o método indutivo faculta, a partir de uma única experiência, formular uma lei ou propor uma generalização em função de uma conclusão. O pesquisador parte de registros de fatores singulares para chegar a uma conclusão ampliada para o fenômeno como um todo. (RUIZ, 1996). Nesse contexto, a repetição da experiência não se faz necessária como uma condição para a indução, dado que as generalizações são inferidas não do número (restrito) dos fenômenos/eventos analisados, mas dos princípios formulados nas premissas. Em outras palavras, sendo as relações de causa / efeito constantes, também o serão as que forem, a partir 
daí, descobertas. Assim sendo, na indução parte-se das verdades particulares para se chegar às verdades gerais.

A indução e a dedução se diferenciam pela forma como se chega a conclusões. Na indução, a observação dos fatos antecede a formulação e confirmação das hipóteses, enquanto na dedução, primeiro deve ser identificado o problema, para depois formular hipóteses e testálas por meio da experimentação. Portanto, na dedução, toda a informação factual da conclusão já estava, pelo menos implicitamente, nas premissas. Já na indução, a conclusão contém informação nova, que não estava, nem implicitamente, nas premissas.

Além da questão do método empregado, as pesquisas podem ser classificadas segundo o objetivo a que se propõe a sua finalidade, o tipo de dados coletados, as técnicas empregadas e outros critérios. Os diversos autores descrevem classificações próprias (LAKATOS; MARCONI, 1991; CERVO; BERVIAN, 2002), priorizando alguns aspectos em relação a outros, o que resulta em um grande número de taxonomias aparentemente conflitantes. Mattar (1993) apresenta uma classificação baseada nas dimensões seguintes:

- Natureza das variáveis pesquisadas:

- pesquisa qualitativa: se refere à existência (qualidade) de algo;

- pesquisa quantitativa: procura medir o grau ou quantidade;

- Natureza do relacionamento das variáveis estudadas:

- pesquisa descritiva: busca descrever "o que", "como", "quando";

- pesquisa causal; busca o "porquê" (relação de causa e efeito);

- Objetivo:

- pesquisa exploratória: procura conhecimento prévio e indicativo;

- pesquisa conclusiva; busca estabelecer conhecimento definitivo e preciso; 
- Forma de coleta de dados:

- pesquisa por comunicação: dados obtidos através da interação direta (entrevista) ou indireta (questionário) com respondente;

- pesquisa por observação: dados obtidos através da observação de fatos ou comportamentos;

- Escopo (amplitude e profundidade):

- estudo de caso; estudo profundo de um ou poucos casos;

- estudo de campo; amplitude e profundidade medianos;

- levantamento amostral; grande amplitude, validade estatística;

- Dimensão no tempo:

- pesquisa ocasional: realizada uma vez, mostra uma situação determinada;

- pesquisa evolutiva: realizada periodicamente, mostra a evolução das variáveis estudadas;

- Possibilidade de controle das variáveis:

- experimento de laboratório;

- experimento de campo: o pesquisador manipula variáveis independentes e verifica seu efeito sobre variáveis dependentes;

- pesquisa ex-post facto: busca descobrir relações entre variáveis após a ocorrência do fenômeno

Para efeito de simplificação, o autor sugere adotar a classificação de pesquisa exploratória ou conclusiva, podendo esta ser descritiva ou causal (MATTAR, 1993), em acordo com Sellitz et al (1974), que identificam três tipos de pesquisa conforme seus objetivos: exploratória, descritiva ou causal. Se o objetivo predominante do estudo é familiarizar-se com um fenômeno pouco estudado e/ou compreendido, o estudo é classificado como exploratório. A abordagem exploratória se baseia no método indutivo, apresentado acima.

A pesquisa em Administração - uma entre as ciências sociais aplicadas - apresenta aspectos bastante peculiares em relação a outros campos da atividade científica; embora busque a 
objetividade que deve caracterizar a produção científica, "a objetividade da ciência do homem é uma objetividade diferente: os seres humanos não são objetos e suas atividades não são simples reações. Em síntese, a relação básica, neste caso, não é de sujeito-objeto, mas de sujeito-sujeito" (ASTI-VERA, 1980:77. apud BRITTO, 2004). Não obstante, “[...] isso não deve ser empecilho intransponível à pesquisa cientificamente embasada, haja vista que a metodologia tem como objetivo ajudar a compreensão, nos mais amplos termos, não dos produtos da pesquisa, mas do próprio processo" (MOURA CASTRO, 1977:48, idem).

Lembrando o problema de pesquisa discutido no Capítulo 1 acima - verificar como (de que forma e utilizando quais instrumentos) e por que (por quais razões e com quais objetivos) os sócios-gestores tomam decisões estratégicas (fazem determinadas escolhas, em situações de grande incerteza sobre aspectos muito relevantes) em uma empresa industrial de pequeno porte (EIPP) - cabe destacar que este tipo de decisão tem sido relativamente pouco estudado, em especial nesse universo. Assim sendo, a presente pesquisa tem caráter exploratório, pois busca contribuir para a ampliação do conhecimento sobre um assunto relativamente pouco explorado pela teoria existente; e utiliza predominantemente o método indutivo, ao buscar deduzir elementos novos, de caráter amplo, da observação de fatos particulares. Nos itens a seguir, os métodos empregados no presente estudo são descritos em maior detalhe.

\subsection{Método de pesquisa}

Os métodos utilizados pelo pesquisador em Administração devem visar antes de tudo oferecer contribuições válidas, ainda que modestas, ao conhecimento sobre o assunto pesquisado. A pesquisa em Administração geralmente enfoca empresas e/ou outras organizações e seus gestores, com freqüência no âmbito de projetos que têm por objetivo influenciar a organização objeto do estudo - a chamada pesquisa participante ou pesquisa- 
ação (SANTOS, 1995). Não obstante, Santos (2008) tem destacado que “o compromisso do pesquisador não é com a empresa, mas com a ciência, ou seja, com a verdade”. Lembrando a epígrafe do presente estudo, a fonte de todo o saber é a dúvida; o desejo de contribuir, ainda que de forma modesta, para o conhecimento científico deve constituir a motivação principal do pesquisador - em especial o que se dedica às ciências humanas, que precisa lidar com a complexidade do seu objeto de estudo e com as suas próprias limitações, além daquelas próprias dos métodos e dos recursos disponíveis.

Sampieri; Collado; Lucio (2006) destacam a questão do enfoque da pesquisa: qualitativo ("utiliza coleta de dados sem medição numérica para descobrir ou aperfeiçoar questões de pesquisa") ou quantitativo ("utiliza coleta de dados para testar hipóteses com base na medição numérica e análise estatística para estabelecer padrões de comportamento") e a sua importância nas ciências sociais, sintetizada no quadro abaixo:

Quadro 09: Enfoque quantitativo x Enfoque qualitativo

\begin{tabular}{|c|c|c|}
\hline \multicolumn{3}{|c|}{$\begin{array}{c}\text { META DAS CIÊNCIAS SOCIAIS: } \\
\text { CONHECER O FENÔMENO SOCIAL }\end{array}$} \\
\hline & Enfoque quantitativo & Enfoque qualitativo \\
\hline Ponto de partida & Há uma realidade a conhecer & Há uma realidade a descobrir \\
\hline Premissas & $\begin{array}{l}\text { A realidade do fenômeno social pode ser } \\
\text { conhecida com a mente. }\end{array}$ & $\begin{array}{l}\text { A realidade do fenômeno social é a mente. A } \\
\text { realidade é construída pelo(s) indivíduo(s) que } \\
\text { dá (dão) significados ao fenômeno social. }\end{array}$ \\
\hline Dados & Uso de medição e quantificação & Uso da linguagem natural \\
\hline Finalidade & $\begin{array}{l}\text { Busca relatar o que acontece. Fatos que } \\
\text { dêem informação específica da realidade } \\
\text { que podemos explicar e prever }\end{array}$ & $\begin{array}{l}\text { Busca entender o contexto e/ou ponto de vista } \\
\text { do ator social }\end{array}$ \\
\hline
\end{tabular}

Fonte: Sampieri; Collado; Lucio (2006:9)

Estes autores apontam a divisão histórica entre os enfoques, destacando porém que 
Se revisarmos os estudos científicos realizados nos últimos anos, [...] observaremos uma tendência crescente [...] o casamento quanti-quali. Isso se deve talvez ao fato de termos percebido que [...] as posições dogmáticas impediram o avanço do conhecimento, por isso, é preciso buscar a convergência ou a triangulação. [...] A triangulação é complementar no sentido de sobrepor enfoques e em uma mesma pesquisa mesclar diferentes facetas do fenômeno de estudo. Tal união ou integração agrega profundidade a um estudo e, ainda que cheguem a surgir contradições entre os resultados de ambos os enfoques, agrega-se uma perspectiva mais completa do que estamos estudando. (SAMPIERI; COLLADO; LUCIO, 2006:12, negrito no original)

Neste ponto, vale lembrar mais uma vez o foco do presente estudo- os processos decisórios estratégicos dos gestores das pequenas empresas, - expresso pela questão Como os sóciosgestores das EIPPs tomam decisões estratégicas? (ver item 1.3). Sendo a questão de pesquisa é do tipo como ou por que, é particularmente indicada a pesquisa qualitativa de estudo de caso (MARINHO 2006). Portanto, a partir da classificação baseada em oito dimensões proposta por Mattar (1993, ver acima), a presente pesquisa apresenta as seguintes características:

Quadro 10: Caracterização do estudo

\begin{tabular}{|c|c|c|}
\hline Dimensão & Caracterização & Justificativa/comentário \\
\hline $\begin{array}{l}\text { Natureza das variáveis } \\
\text { pesquisadas }\end{array}$ & pesquisa qualitativa & refere-se à existência (qualidade) de algo \\
\hline $\begin{array}{l}\text { Natureza do } \\
\text { relacionamento das } \\
\text { variáveis estudadas }\end{array}$ & pesquisa descritiva & busca descrever o "como" \\
\hline Objetivo & pesquisa exploratória & procura conhecimento prévio e indicativo; \\
\hline $\begin{array}{l}\text { Forma de coleta de } \\
\text { dados }\end{array}$ & Pesquisa por comunicação & $\begin{array}{c}\text { dados obtidos através da interação direta } \\
\text { (entrevista) ou indireta (questionário) com } \\
\text { respondente; }\end{array}$ \\
\hline \multirow[t]{2}{*}{ Escopo } & estudo de campo & análise de dados secundários \\
\hline & estudo de caso & estudo profundo de um ou poucos casos \\
\hline Dimensão no tempo & pesquisa ocasional & $\begin{array}{c}\text { realizada uma vez, mostra uma situação } \\
\text { determinada }\end{array}$ \\
\hline $\begin{array}{l}\text { Possibilidade de } \\
\text { controle das variáveis }\end{array}$ & pesquisa ex-post facto & $\begin{array}{c}\text { busca descobrir relações entre variáveis após a } \\
\text { ocorrência do fenômeno }\end{array}$ \\
\hline
\end{tabular}

FONTE: elaborado pelo autor 
Yin (2001) define os estudos de caso em termos de processo de pesquisa, afirmando ser esta "uma pesquisa empírica que investiga um fenômeno contemporâneo, dentro de um contexto de vida real", especialmente indicado quando as características do problema pesquisado são de natureza interpretativa e comportamental e sofrem interferência de fatores não controláveis. Quanto à seleção do tipo de estudo de caso, Yin (1984), indica duas dimensões: caso único ou casos múltiplos; e holístico ou incorporado - respectivamente (a) abordando características gerais da organização ou (b) introduzindo níveis específicos de análise. $\mathrm{O}$ mesmo autor destaca a importância de se preparar a coleta de dados, indicando a necessidade da elaboração de um protocolo.

O mesmo autor destaca que esta forma de investigação tem sido considerada menos válida do que experimentos ou levantamentos, em razão (a) da impossibilidade de se generalizar dos resultados e (b) uma suposta falta de rigor científico. Por outro lado, Patton e Appelbaum (2003) argumentam que o uso do estudo de casos oferece a possibilidade de obter-se uma visão abrangente dos processos administrativos, sendo ideal para compreender as organizações, tendo em vista a difícil mensuração das observações.

Portanto, a validade do estudo de caso depende fundamentalmente do rigor dos seus procedimentos, devendo pautar-se pela utilização de uma fundamentação teórica preliminar baseada nas teorias existentes (EISENHARDT, 1989). A utilização de um modelo teórico ex ante proporciona foco ao estudo e um melhor direcionamento quanto à determinação dos dados a serem coletados, permitindo - respeitadas as limitações do método - a chamada generalização analítica, ou seja, o contraste entre o referencial teórico a ser revisitado e a realidade empírica investigada. 
Dadas as definições acima, o caso a ser estudado é do tipo holístico e único. Com o objetivo de ampliar a discussão, o caso principal será complementado com um caso de apoio; em outras palavras, a análise do caso principal (estudo em profundidade de uma decisão estratégica específica na empresa BETA) será complementado com a análise mais sucinta de situação semelhante em empresa com características diferentes. Não obstante, o autor do presente estudo considera tratar-se um estudo de caso único, principalmente considerando que os elementos dos casos de apoio não são tratados de per si, mas sim em confronto com os correspondentes elementos do caso principal.

O caso principal (o texto indicará a empresa como BETA, mantendo-se o sigilo das informações sem prejuízo à qualidade das análises, visto o autor ter autorização para demonstrar as informações relevantes para a pesquisa) analisa o processo decisório quanto a alternativas estratégicas para a preparação da empresa para uma reforma societária. Esta deve envolver a venda da totalidade das cotas de um dos sócios - e possivelmente parte das cotas do sócio remanescente - a uma terceira parte, podendo esta ser uma pessoa física (que provavelmente assumiria as funções do sócio egresso) ou uma pessoa jurídica, presumivelmente uma empresa de venture capital.

A BETA é uma pequena indústria atuante no setor de produtos de limpeza industrial e institucional (I\&I). A BETA (a) é de capital totalmente nacional e de pequeno porte; (b) atua em um setor estabilizado, com alta rivalidade e baixas barreiras de entrada; (c) fabrica produtos com baixo potencial de diferenciação em escala modesta em relação aos padrões do setor; (d) apresenta estrutura enxuta, com dois sócios gestores dividindo as funções gerenciais, ambos possuindo formação acadêmica, em administração de empresas e engenharia, respectivamente. 
O caso de apoio consiste na análise de uma decisão semelhante - uma transação de cotas entre os sócios - na empresa DELTA, que apresenta algumas características bastante diversas da BETA; (a) capital misto, embora de pequeno porte; (b) setor de tecnologia, com rivalidade moderada e barreiras de entrada relativamente altas; (c) produtos e serviços de alto envolvimento, vendas de projetos com grande potencial de diferenciação; (d) funções gerenciais exercidas apenas pelo sócio brasileiro, com formação em engenharia.

Adicional e anteriormente ao estudo de caso - em um esforço para (a) sistematizar parte do conhecimento existente sobre o tema abordado e (b) fornecer subsídios para o estudo do caso em questão - o presente estudo inclui a análise de dados secundários colhidos por duas pesquisas anteriores, já citadas no Capítulo 2: os estudos de Britto (2004) e Barbero (2008), ambos sobre empresas industriais do estado de São Paulo. O primeiro apresenta um panorama geral da indústria paulista - do qual o presente estudo enfocará as EIPPs - do ponto de vista da sua competitividade no mercado globalizado, que o autor analisou quanto à sua prontidão para exportar (CAVUSGIL apud BRITTO, ver acima) - que inclui em certa medida a decisão de fazê-lo. Já Barbero (2008) estuda a formação de estratégias nas indústrias paulistas; o presente estudo busca um recorte mais específico, ao analisar o processo decisório estratégico (um dos aspectos da formação de estratégias) no âmbito da EIPPs, nas quais provavelmente este processo assuma formas específicas.

Em resumo, em termos de método ou enfoque o presente estudo apresenta-se como fundamentalmente qualitativo; incorpora, não obstante, dados e métodos quantitativos. Estes, de forma geral, têm por objetivo identificar possíveis padrões e/ou relações a serem exploradas no estudo de caso. Os principais dados utilizados, bem como as análises a serem 
realizadas, são descritos no item 3.3 abaixo, logo após a definição do universo e das estratégias do estudo; os resultados são apresentados e discutidos no próximo capítulo.

\subsection{Definição do universo e das estratégias do estudo}

O universo do presente estudoé constituído pelas empresas industriais de pequeno porte (EIPPs) do estado de São Paulo, associadas da FIESP e ativas em 2004, ano da publicação do cadastro disponível para o autor. Estas constituem um subconjunto do universo estudado por Britto (2004) e Barbero (2008), cujas pesquisas analisaram todas as empresas industriais paulistas associadas à FIESP, excetuadas apenas (a) as 200 consideradas super-grandes, (b) as micro-empresas, com até dez funcionários (algumas das quais incluídas na pesquisa de Barbero) e (c) aquelas exclusivamente prestadoras de serviços. Os dados secundários analisados se referem a (1) uma amostra de cerca de 400 empresas colhida por Britto (2004) e (2) uma amostra semelhante de empresas analisadas por Barbero (2008). Tanto as empresas que serão objeto do estudo de caso (principal e de apoio) quanto as bases de dados secundários foram escolhidas por conveniência, em função do acesso do autor do presente estudo à diretoria das empresas e pela disponibilização dos dados pelos autores supracitados.

A análise dos dados secundários utiliza as respostas (a) do subconjunto das questões de cada um dos instrumentos utilizados nas referidas pesquisas referentes ao tema do presente trabalho e (b) dos respondentes identificados como gestores de EIPPs, definidas conforme o item 1.6 acima: 10 a 50 funcionários e faturamento anual entre $\mathrm{R} \$ 2 \mathrm{M}$ e $20 \mathrm{M}$. Das cerca de 400 empresas estudadas por Britto (2004), 163 (cento e sessenta e três) se enquadram nesta definição, bem como 20 (vinte) das empresas analisadas por Barbero (2008). Cabe destacar que foi adotado o critério de analisar apenas os dados referentes a empresas enquadradas em 
ambos os critérios de porte (número de funcionários e faturamento anual) e cujo respondente tivesse se identificado claramente como sócio-gestor (sócio proprietário ou presidente).

Os objetivos desta etapa são:

- apresentar uma descrição geral das EIPPs paulistas - ramo, porte, faturamento, tempo de existência, formas de atuação, - com ênfase na sua prontidão para atuar no mercado globalizado (prontidão organizacional);

- descrever e analisar algumas características dos sócios-gestores destas empresas;

- estudar algumas características de uma decisão estratégica específica, a saber, a decisão de exportar;

- finalmente, analisar o processo estratégico destas empresas, principalmente os aspectos ligados ao processo decisório do sócio-gestor;

Para tanto, serão desenvolvidas análises estatísticas de subconjuntos de dados das pesquisas supracitadas (BRITTO, 2004 e BARBERO, 2008), constituídos pelas respostas de sócios gestores de EIPPs às questões ou grupos de questões referentes a estes assuntos (ver Capítulo 7: Anexos). A estrutura e os procedimentos adotados para estas análises são descritos no item seguir e seus resultados são apresentados e discutidos no próximo capítulo.

A etapa final, o estudo de caso, tem por objetivo analisar em maior profundidade o processo decisório estratégico do sócio-gestor da EIPP, sendo para tanto analisadas determinadas decisões, cujo caráter estratégico é reconhecido por estes. Trata-se, em outras palavras, de confrontar o referencial teórico levantado e certos resultados de pesquisas anteriores com a descrição de casos específicos, buscando principalmente elementos discrepantes e/ou não considerados; o resultado possível - e desejado - deste confronto é o fornecimento de insights 
quanto a elementos que proporcionem aperfeiçoamentos do referencial teórico. O roteiro conceitual do estudo é esquematizado na figura a seguir e os procedimentos adotados são discutidos no próximo item.

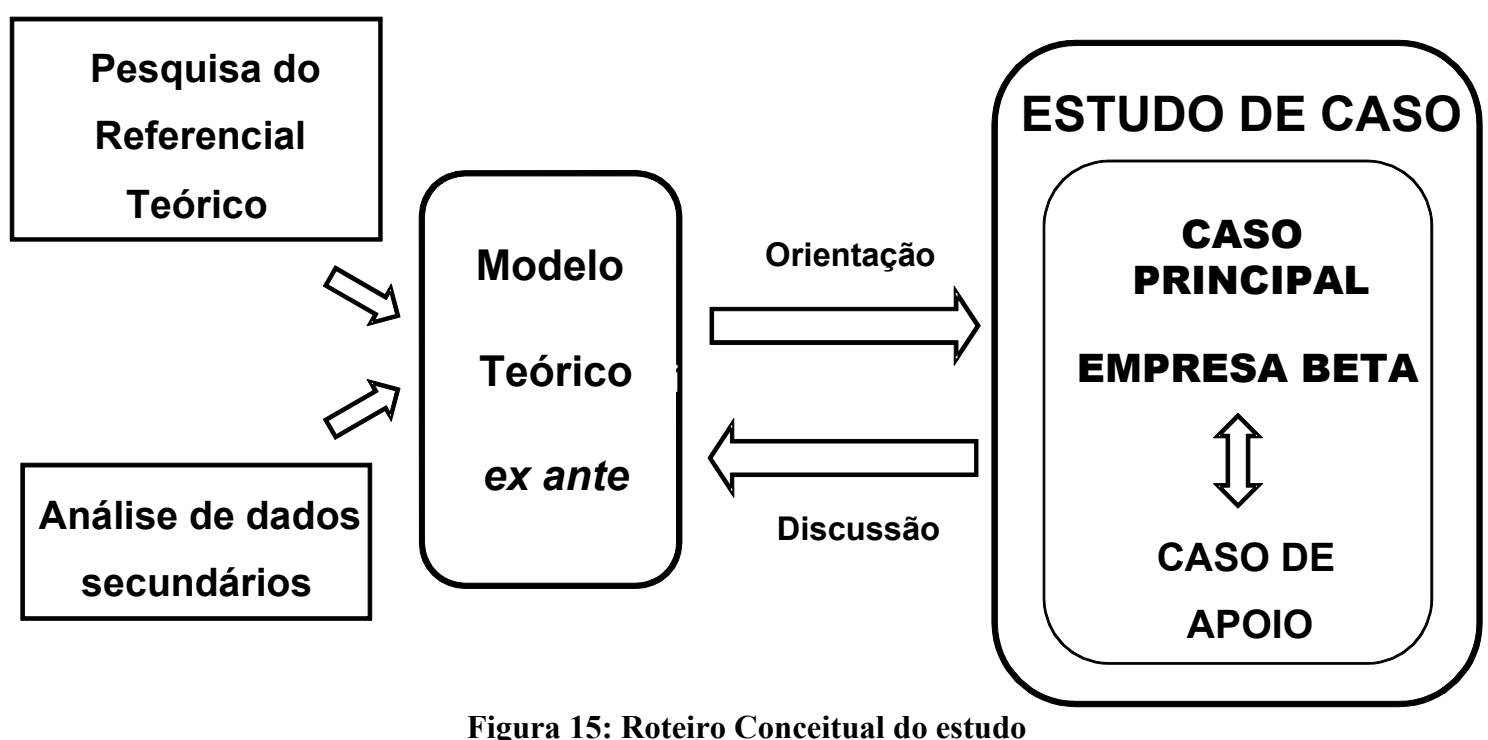

FONTE: elaborada pelo autor

\subsection{Procedimentos}

Os procedimentos utilizados para a coleta (durante as pesquisas originais) dos dados secundários utilizados no presente estudo diferiram entre as pesquisas. Britto (2004) utilizou amostragem estatística estratificada e aplicação dos questionários por entrevistadores, enquanto Barbero (2008) adotou uma amostra por conveniência, com a aplicação de questionários de auto-preenchimento via Internet. Cumpre destacar que, dado o caráter exploratório do presente estudo, não se busca a generalização dos seus resultados, sendo portanto o tamanho e a representatividade das amostras utilizadas de importância secundária. Não obstante, o tamanho das mesmas - respectivamente, 163 e 20 EIPPs - e sua representatividade do universo pesquisado (ver acima) permite supor que os resultados oferecem indicações válidas sobre os aspectos analisados. 
Os dados da pesquisa de Britto (2004) utilizados no presente estudo se referem fundamentalmente à descrição das EIPPs paulistas, sendo portanto consideradas apenas as repostas fornecidas pelos gestores destas. Buscou-se captar alguns aspectos que, em conjunto, se poderiam denominar de "maturidade organizacional" destas empresas e de seus gestores. As questões foram selecionadas e reorganizadas em três perspectivas - Empresa, Gestor, Decisão de Exportar - e cada uma destas em aspectos (quadro abaixo).

Quadro 11: Perspectivas e aspectos de maturidade organizacional das EIPPs

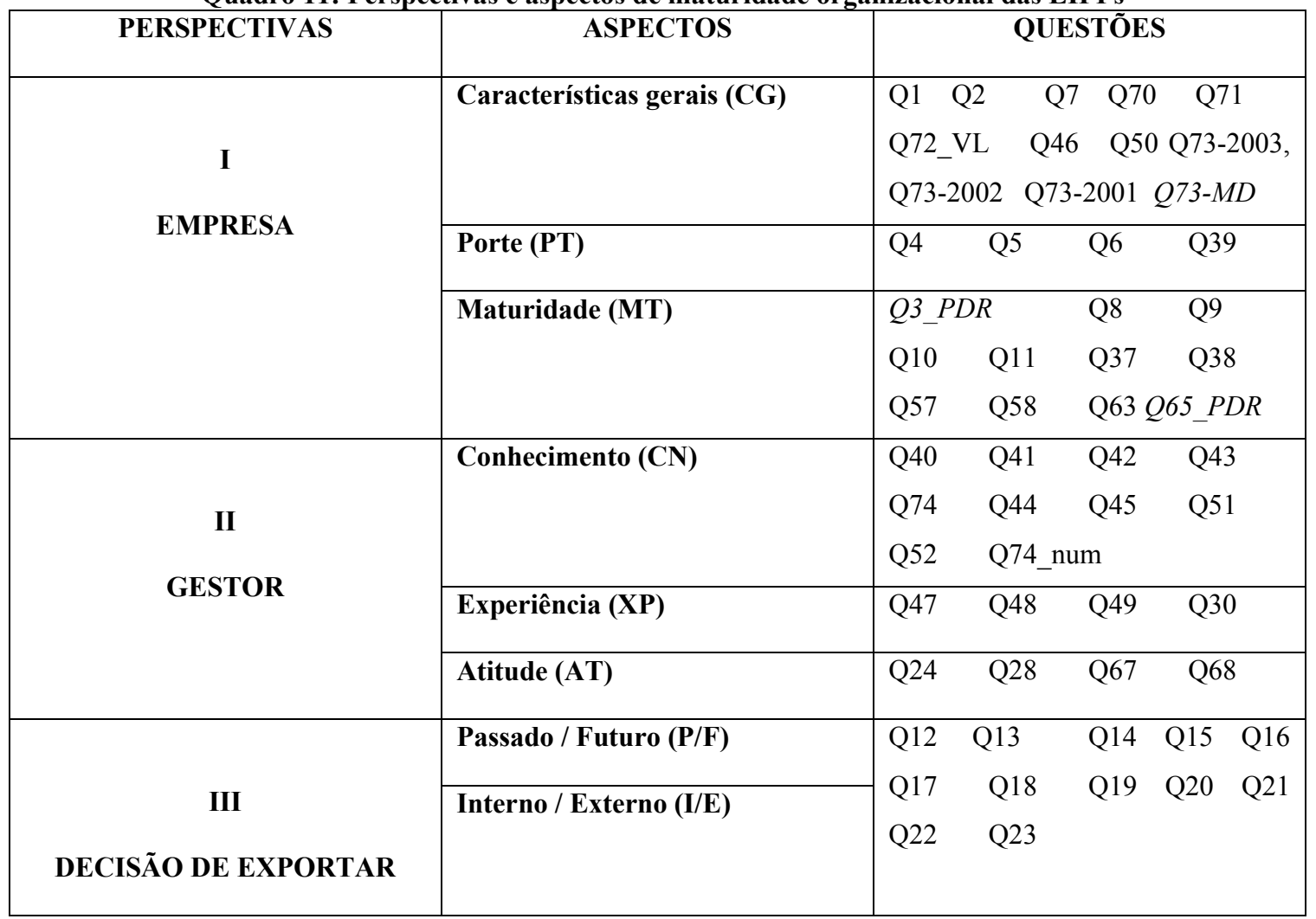

Fonte: elaborado pelo autor

Esta divisão tem por objetivo buscar identificar possíveis relações entre as características da empresa, do gestor e de uma decisão estratégica (de exportar). Para tanto, são apresentadas inicialmente estatísticas descritivas referentes às características gerais $(\mathrm{CG})$ das empresas e a seu porte (PT). A partir das respostas às questões referentes à Maturidade, é construído um 
Indicador de Maturidade Organizacional da Empresa; de forma semelhante, Conhecimento e Experiência constituem o Indicador de Maturidade Organizacional do Gestor. A construção destes indicadores e sua análise são apresentadas e discutidas no Capítulo 4, juntamente com os resultados correspondentes.

Já para os dados secundários da pesquisa de Barbero (2008), são fundamentalmente refeitas as análises estatísticas presentes no estudo original, restritas às respostas do gestores de EIPPs às questões relacionadas mais diretamente com o objetos de interesse do presente estudo. São utilizadas doze das dezessete questões (grau de concordância com assertivas, medida por meio de escala Likert), agrupadas em três grupos de quatro, referentes às três dimensões do modelo teórico do estudo (ver item 2.6 acima). Estas análises e seus resultados também são apresentados no Capítulo 4 a seguir. Cumpre destacar que, embora o tamanho da amostra -20 EIPPs- limite a validade dos resultados, o forte alinhamento do seu objeto de estudo com os objetivos deste estudo deve proporcionar insghts importantes.

Quanto à coleta de dados primários do estudo de caso, foi utilizada a técnica da entrevista, utilizando questionário semi-estruturado, (ver Capítulo 7: Anexos), aplicado pelo próprio pesquisador, com gravação da entrevista. Tanto a gravação quanto o uso dos dados para fins de pesquisa foram devidamente autorizadas por escrito pelos entrevistados. O protocolo do estudo de caso foi baseado no modelo utilizado por Barbero (2008), que também é apresentado nos anexos do presente estudo. A análise das entrevistas do EC é realizada a partir da identificação e estruturação dos principais conceitos apresentados pelos respondentes durante as entrevistas. Inicialmente, são apresentados (ao final da descrição de cada caso) dois quadros que contém as sentenças mais significativas presentes nas respostas de cada entrevistado a cada questão. 
Em seguida, é feita a sobreposição dos quadros e sintetizados os principais conceitos referentes a cada questão, a partir do agrupamento das sentenças/conceitos presentes nas respostas de todos os respondentes. Busca-se, desta forma, agrupar e estruturar as percepções dos respondentes sobre cada questão, de forma a identificar possíveis regularidades, bem como a concordância e/ou discrepância entre o modelo teórico do estudo, as indicações fornecidas pela análise dos dados secundários e os elementos trazidos pelos respondentes.

O conjunto destas análises e seu confronto com os elementos trazidos pela revisão do referencial teórico, em especial o modelo do estudo, deverão fornecer os elementos para as conclusões do estudo, apresentadas no Capítulo 5. 


\section{RESULTADOS E ANÁLISES}

No capítulo anterior, foram descritos de forma geral o enfoque, as estratégias e os métodos empregados na etapa de campo do presente estudo. Neste capítulo, são apresentados os dados levantados, os resultados obtidos e as análises realizadas. Conforme já assinalado, estas análises foram realizadas em duas etapas, referentes a dois conjuntos de dados, a saber, (a) dados secundários e (b) dados de entrevistas do estudo de caso.

Considerando a natureza essencialmente qualitativa do estudo, o autor entende que a análise dos dados secundários - de cunho essencialmente quantitativo - constitui uma etapa complementar, cuja finalidade é fornecer elementos para a discussão dos elementos qualitativos do estudo. Assim sendo, optou-se por concentrar no item 4.1 a seguir todos os elementos referentes à análise quantitativa dos dados secundários, inclusive a definição conceitual e operacional das variáveis e as hipóteses a serem analisadas.

No item 4.2, são realizadas as análises e discussão dos elementos levantados no Estudo de Caso, consistindo fundamentalmente no confronto entre as respostas de cada entrevistado e destas com as indicações fornecidas pelo referencial teórico e pelos resultados do item anterior. Esta discussão fornece os elementos para as considerações finais e conclusões desenvolvidas no Capítulo 5.

\subsection{Análise dos dados secundários}

Conforme já referido no capítulo anterior, neste item são apresentadas análises dos conjuntos de dados secundários das pesquisas de Brito (2004) e Barbero (2008). Da pesquisa de Britto (2004) buscou-se captar, além de um panorama geral das EIPPS paulistas e de seus gestores, 
alguns aspectos que, em conjunto, pode-se denominar de "maturidade organizacional". Para tanto, as questões foram selecionadas e reorganizadas em três perspectivas - Empresa, Gestor, Decisão de Exportar - e cada uma destas em aspectos, conforme o quadro apresentado no capítulo anterior. Para cada uma das duas primeiras dimensões, foi elaborado um indicador denominado respectivamente Índice de Maturidade Organizacional da Empresa (IMOE) e Índice de Maturidade Organizacional do Gestor (IMOG). Ambos foram definidos de forma que o seu valor variasse entre 0 e 100, permitindo a sua comparação com os escores calculados pelo CORE. As principais análises realizadas se referem a verificar se os gestores com pós-graduação apresentam desempenho diferenciado.

Quanto à análise da decisão de exportar, esta se refere à verificação se a decisão é mais influenciada por padrões do passado ou pela visão do futuro; e pelos aspectos do ambiente externo ou interno. Para tanto, também foram construídos indicadores a partir das respostas às questões pertinentes; esta análise é apresentada mais adiante, juntamente com discussão semelhante a partir de dados da pesquisa de Barbero (2008).

Das 163 EIPPs estudadas por Britto, 105 se localizavam na região metropolitana (Grande São Paulo); 65 se encontravam em regiões de alta concentração de empresas do setor (na GSP, 50 empresas). Apenas oito empresas tinham participação de capital estrangeiro. Quanto à abrangência da atuação, 28 empresas atuavam localmente (sua cidade e vizinhanças), 66 no estado de São Paulo e 59 em escala nacional.

A medida de participação de mercado, considerada muito importante por grandes empresas, mostra uma peculiaridade das EIPPs analisadas: 90 empresas responderam simplesmente ignorar o seu market share e apenas 48 empresas afirmaram deter participação no mercado 
brasileiro igual ou superior a 10\%. Esta é uma indicação de que a medida de participação de mercado geralmente tem pouco valor e significado quando se trata de pequenas empresas. Apenas 36 empresas apresentavam alguma atividade exportadora; destas, curiosamente, 12 não atuavam em todo o Brasil. A participação das exportações no faturamento é modesta: 0,62\% em média (três anos anteriores à pesquisa), entre as empresas exportadoras. Estes dados parecem confirmar a característica de atuação local das empresas de pequeno porte.

Quanto ao porte, estão presentes duas medidas - faturamento anual e número de colaboradores. As empresas com faturamento até $\mathrm{R} \$ 1,2 \mathrm{M}$ são 62 , com em média 25 colaboradores, o que leva a se estimar valores típicos de faturamento da ordem de R\$ 40.000/colaborador/ano, ou até menos. Considerando que na próxima faixa (faturamento de R\$ 1,2 a $10,5 \mathrm{M})$ estão 85 empresas que tinham em média 32 funcionários ( $\mathrm{R} \$$ 180.000/colaborador/ano), caberia um questionamento quanto a esta diferença entre os valores de faturamento/funcionário. Apenas 10 empresas reportaram faturamento anual entre $\mathrm{R} \$ 10,5$ e $15 \mathrm{M}$, com 38 colaboradores e R\$ 335.000/colaborador/ano em média. Estas indicações e estimativas devem ser consideradas com reservas, visto os dados sobre o faturamento estarem definidos em faixas muito amplas.

Avaliando a evolução das vendas, se evidencia a deficiência de muitas EIPPs quanto a controles: 17 gestores - mais de 10\% - afirmaram não saber a taxa de crescimento das vendas da empresa nos três anos anteriores à pesquisa; 7 das empresas com faturamento até $\mathrm{R} \$$ 1,2M/ano, 8 na faixa intermediária e 2 na faixa superior. Queda ou crescimento zero foram informados por 41 empresas (24 na $1^{\text {a }}$ faixa, 16 na $2^{\text {a }}$ e 1 na faixa superior). Das 99 empresas que reportaram crescimento das vendas, 7 reportaram crescimento superior a 50\%; desconsideradas estas outlayers, a média do crescimento (das que cresceram) ficou em 11\%, 
com grande dispersão (desvio-padrão de 2.5 vezes a média). Cabe a observação de que estes resultados podem ser muito influenciados pelo fato de se medir o crescimento nominal ou real (descontada a inflação), além de outras possíveis fontes de erros. Assim sendo, também estas avaliações devem ser encaradas com reservas. Não obstante, estas grandes variações parecem estar em acordo com a visão de Escrivão Filho e outros autores citados acima de que provavelmente os critérios quantitativos mais utilizados para definir a pequena empresa (faturamento e número de funcionários) não sejam realmente adequados para "agrupar semelhanças e distinguir diferenças”, sendo necessário aperfeiçoá-los.

Quanto à questão da maturidade da empresa e do gestor, foram considerados os seguintes parâmetros: idade da empresa (tempo de atuação, Q3); a quantidade de sistemas informatizados (Q65), padronizada de forma a variar de 0 (nenhum sistema) a 10 (seis ou mais, Q65_PDR); Índice de Maturidade Organizacional da Empresa (IMOE); Índice de Maturidade Organizacional do Gestor (IMOG); e os escores do CORE: Global (SCR_TT), Atuação no Mercado Doméstico (SCR_DM1), Recursos (SCR_DM4) e Treinamento (SCR_DM5). Foram calculadas a média e desvio-padrão de cada uma destas variáveis para todas as empresa e depois recalculadas as médias dos subgrupos das empresas cujo gestor tinha pós graduação (29 empresas, media_1) ou não (134 empresas, media_0). As médias são comparadas usando o parâmetro $t_{\text {student }}$, assumindo-se que o desvio-padrão de cada subgrupo é igual ao da amostra e que valores absolutos de $t>1$ já indicam diferença significativa.

Tabela 02: Medidas de maturidade das EIPPs e dos gestores

\begin{tabular}{lrrrrrrrrr} 
& Q3_id & Q65_PDR & IMOE & IMOG & \multicolumn{1}{c}{$\boldsymbol{S C R} \boldsymbol{T} \boldsymbol{T}$} & \multicolumn{1}{c}{ SCR_DM1 } & SCR_DM4 & SCR_DM5 \\
media & 23,53 & 2,32 & $\mathbf{5 0 , 8 3}$ & $\mathbf{4 6 , 6 0}$ & $\mathbf{4 3 , 6 9}$ & $\mathbf{4 6 , 7 0}$ & $\mathbf{2 9 , 0 6}$ & $\mathbf{3 2 , 9 7}$ \\
despad & 16,37 & 2,57 & $\mathbf{1 3 , 7 6}$ & $\mathbf{1 3 , 6 2}$ & $\mathbf{1 3 , 1 9}$ & $\mathbf{1 2 , 9 6}$ & $\mathbf{1 8 , 5 7}$ & $\mathbf{2 2 , 0 5}$ \\
& & & & & & & \\
media_0 & 22,45 & 2,47 & 51,30 & 45,99 & $\mathbf{4 3 , 9 6}$ & $\mathbf{4 7 , 5 2}$ & $\mathbf{2 8 , 1 5}$ & $\mathbf{3 2 , 6}$ \\
media_1 & 28,27 & 1,66 & 48,75 & 51,08 & $\mathbf{4 2 , 4 8}$ & $\mathbf{4 3 , 0 7}$ & $\mathbf{3 3 , 0 7}$ & $\mathbf{3 4 , 6 2}$ \\
t_stdt & 1,74 & $-1,54$ & $-0,91$ & 1,82 & $-0,55$ & $-1,68$ & 1,29 & 0,45 \\
& \multicolumn{7}{c}{ Fonte: elaborado pelo autor baseado em Britto (2004) }
\end{tabular}


As empresas analisadas atuam em média há 23 anos, um número alto, considerando que os dados do SEBRAE sobre mortalidade das pequenas empresas indicam que apenas cerca de um terço das empresas sobrevive até o quinto ano. Tipicamente, os gestores com pós graduação dirigem empresas "mais velhas" (a diferença entre as médias é significativa). Ao contrário do esperado, estas empresas são menos informatizadas e sua atuação no mercado nacional (SCR_DM1) poderia ser considerada menos robusta do que a média das empresas geridas por gestores sem pós graduação, o que aparentemente é confirmado pelo IMOE e pelo Escore Global do CORE (SCR_TT). Cumpre notar que estes valores são todos bastante baixos, tipicamente inferiores a 50. Justamente nos fatores que apresentam valores mais baixos - por volta de 30, para Recursos (SCR_DM4) e Treinamento (SCR_DM5) - as empresas geridas por pós graduados apresentam leve vantagem.

Talvez isso indique que valeria para os cursos de pós graduação a mesma crítica endereçada por Escrivão Filho aos cursos de graduação em Administração: o que se ensina não serve para as pequenas empresas. Outra possibilidade é que parte dos gestores tenha se pós graduado em cursos não voltados à gestão da empresa. De qualquer forma, seria de se esperar um grande ganho da empresa em função do maior preparo intelectual e acadêmico do seu principal gestor; ainda que a indicação oferecida por este estudo tenha validade limitada, este dado é intrigante. A última parte desta análise - referente à decisão de exportar - será apresentada ao final deste item, juntamente com a parte final da análise dos dados secundários da pesquisa de Barbero (2008), que é desenvolvida a seguir.

A análise dos dados secundários da pesquisa de Barbero (2008) oferece elementos relacionados diretamente com o objeto de interesse do presente estudo. Duas questões se referem a premissas do estudo - processo de decisão individual e processo apolítico - e doze 
questões (agrupadas em três grupos de quatro) fornecem indicações quanto às três dimensões do modelo teórico do estudo (ver item 2.6 acima); segundo o qual o processo decisório do gestor da EIPP estaria sujeito a influências cognitivas (racionalidade x intuição), ambientais (ambiente externo x interno) e atitudinais (padrões do passado x visão de futuro).

A primeira afirmativa a ser analisada é "O principal executivo determina nossas estratégias"; a premissa de que o processo decisório estratégico na EIPP seria fundamentalmente individual (a cargo do sócio-gestor), seria de se esperar um alto grau de concordância, o que se verifica em certa medida (55\%, contra $40 \%$ de discordância). Cabe observar que a resposta é do próprio gestor, que pode julgar que as suas decisões não se traduzem efetivamente em estratégias, podendo assim levar o respondente a discordar da afirmativa.

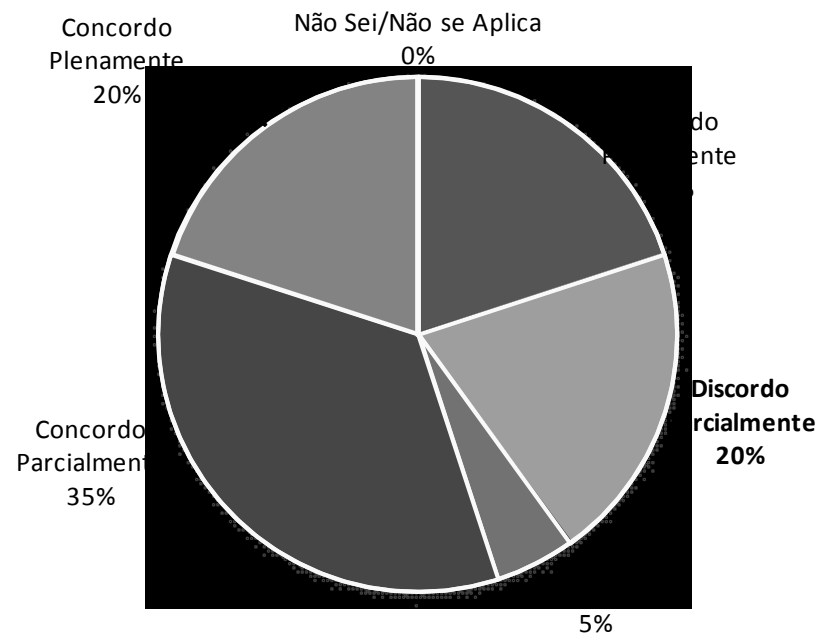

Gráfico 01: Respostas quanto ao grau de concordância à assertiva "O principal executivo determina nossas estratégias" Fonte: elaborado pelo autor a partir de Barbero (2008)

A afirmativa "As estratégias tem de ser alteradas porque algum grupo dificulta a implantação" é a mais diretamente relacionada com o processo político, entendido como um conjunto de influências que levaria a decisões "menos racionais" em função de interesses de determinados grupos. A forte discordância $(85 \%)$ parece sustentar a premissa de que nas EIPPs o processo político não constitui uma influência muito importante. 


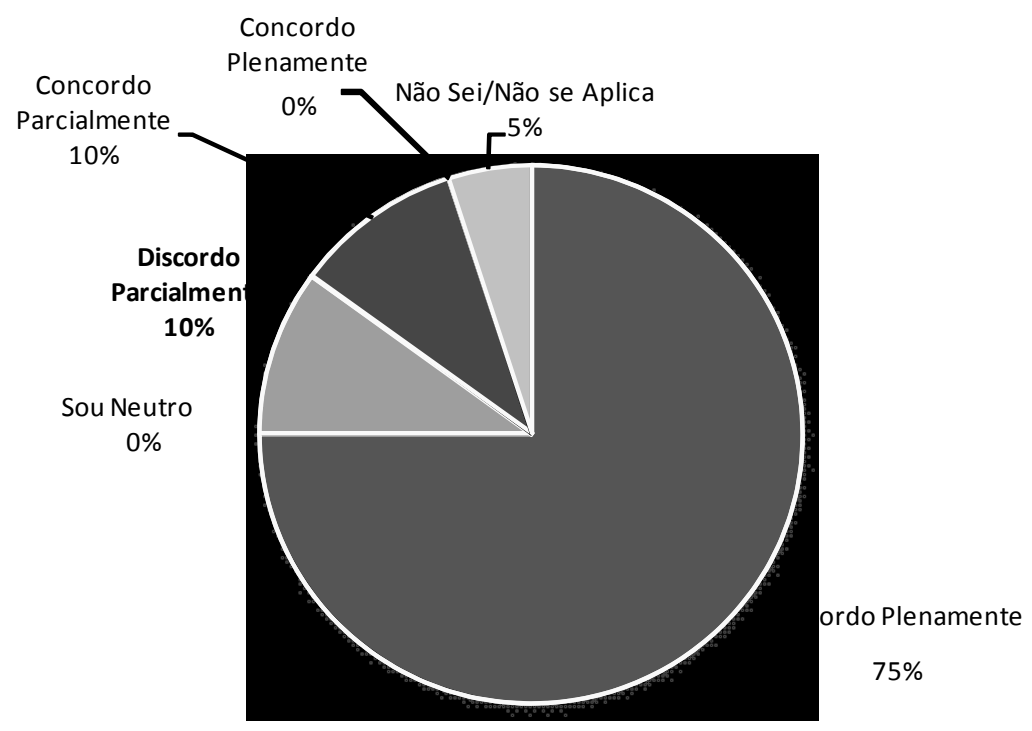

Gráfico 02: Respostas quanto ao grau de concordância à assertiva "As estratégias tem de ser alteradas porque algum grupo dificulta a implantação" Fonte: elaborado pelo autor a partir de Barbero (2008)

Conforme indicado acima, para cada dimensão (ou eixo, cognitivo, atitudinal, ambiental) foram identificadas quatro assertivas. $\mathrm{O}$ grau de concordância ou discordância com estas assertivas oferece indicações quanto à influência sobre o processo decisório. Por exemplo, a resposta "Concordo plenamente" à assertiva "As estratégias de nossa empresa são continuidade dos padrões de ação do passado" indica um preponderância da influência dos padrões do passado (em relação à visão de futuro, eixo atitudinal); ou o oposto, se a resposta fosse "Discordo plenamente". Notar que a palavra "ambiente" é usada no sentido de “ambiente externo", o que é indicado por uma observação de "Nota do autor" (NdA).

As assertivas que se referem à dimensão cognitiva (racionalidade x intuição) - As estratégias de nossa empresa são decididas em um processo de Planejamento Estratégico; Avaliamos alternativas antes de definir as estratégias; Temos objetivos estratégicos bem definidos; Avaliamos racionalmente nosso ambiente (externo, NdA) de negócios (concorrentes, mercado etc.) - mostram uma forte concordância, da ordem de $85 \%$; os gestores parecem considerar-se predominantemente racionais. 


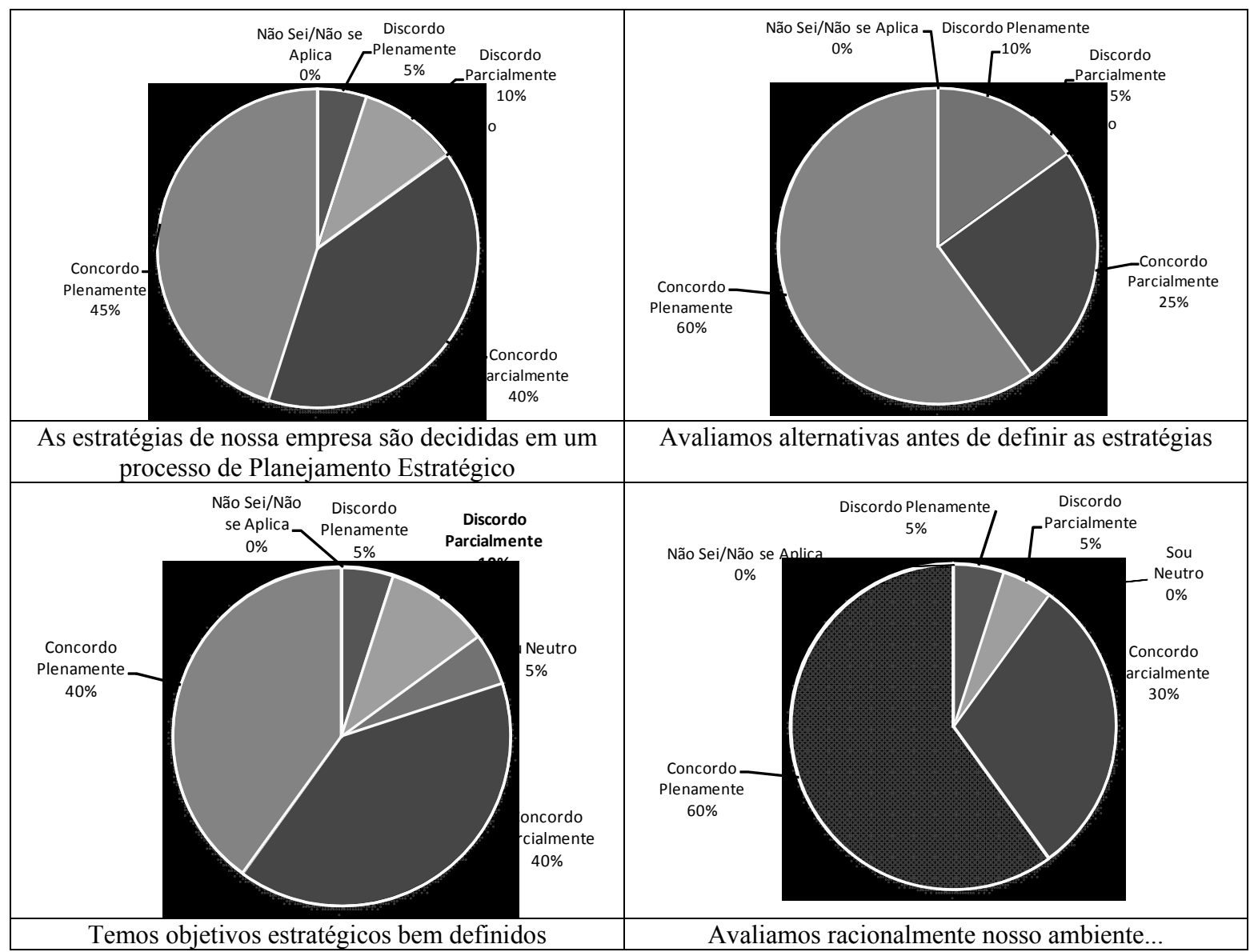

Gráfico 03: Respostas quanto ao grau de concordância às assertivas referentes a influências cognitivas (racionalidade $x$ intuição)

Fonte: elaborado pelo autor a partir de Barbero (2008)

As assertivas que se referem à dimensão ambiental (ambiente externo $\mathrm{x}$ interno) - As estratégias são definidas de tal forma a acomodar os diferentes interesses de pessoas e grupos internos (departamentos, áreas, gerentes etc.); Os interesses de um grupo de pessoas em particular dão o "tom" das estratégias; Para nos manter alinhados ao nosso ambiente (externo, NdA) mudamos nossa estratégia; A maioria das mudanças estratégicas em nossa empresa ocorre por forças externas (movimentação de concorrentes, novas leis, exigências dos consumidores etc.) - indicam que a avaliação do ambiente (interno e externo) é uma influência importante, com predominância das considerações referentes ao ambiente externo. Em particular, nota-se forte discordância quanto à influência de pessoas e grupos sobre as estratégias, acompanhada de grande ênfase na "análise racional do ambiente” (externo). 


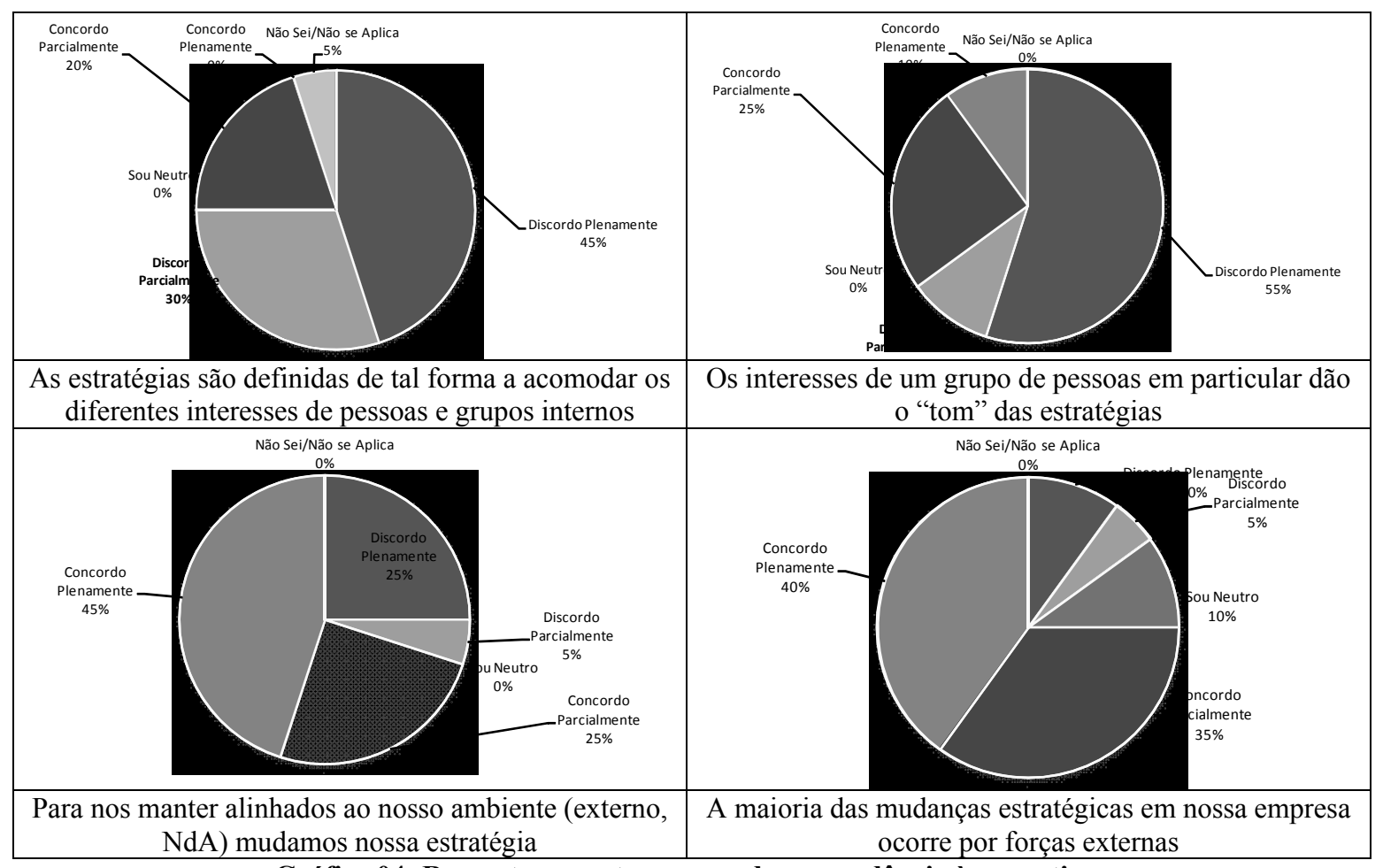

Gráfico 04: Respostas quanto ao grau de concordância às assertivas referentes a influências ambientais (ambiente externo $x$ interno)

Fonte: elaborado pelo autor a partir de Barbero (2008)

Quanto às assertivas que se referem à dimensão atitudinal (padrões do passado $\mathrm{x}$ visão de futuro) - Nossas estratégias refletem “o jeito que fazemos as coisas por aqui”; As estratégias de nossa empresa são continuidade dos padrões de ação do passado; As estratégias têm de ser alteradas porque algum grupo dificulta sua implantação; Nossa liberdade para fazer escolhas é restringida porque o ambiente (externo, NdA) externo à empresa (mercado, concorrência, governo etc.) determina as direções - faz-se necessária uma discussão um tanto diferente das anteriores. As duas primeiras assertivas - destacadas em negrito - claramente se referem à dimensão analisada. Em geral, verifica-se concordância (55-60\%), indicando predominância de padrões do passado - não obstante, há uma divergência (20-25\% de "discordo muito"), que pode indicar uma minoria fortemente comprometida com a necessidade de mudanças, ou seja, com decisões baseadas na visão de um futuro bastante diferente do passado. A terceira assertiva poderia indicar uma "posição reacionária” de certos grupos (há forte discordância, conforme já discutido acima), enquanto 
a última poderia refletir um "hábito mental" de considerar "regras do jogo" totalmente estabelecidas, o que não deixaria espaço para mudanças provocadas por decisões do gestor. A concordância com esta assertiva é da mesma ordem das duas primeiras, reforçando a percepção que, de forma geral, a influência dos padrões do passado predomina sobre a visão do futuro.

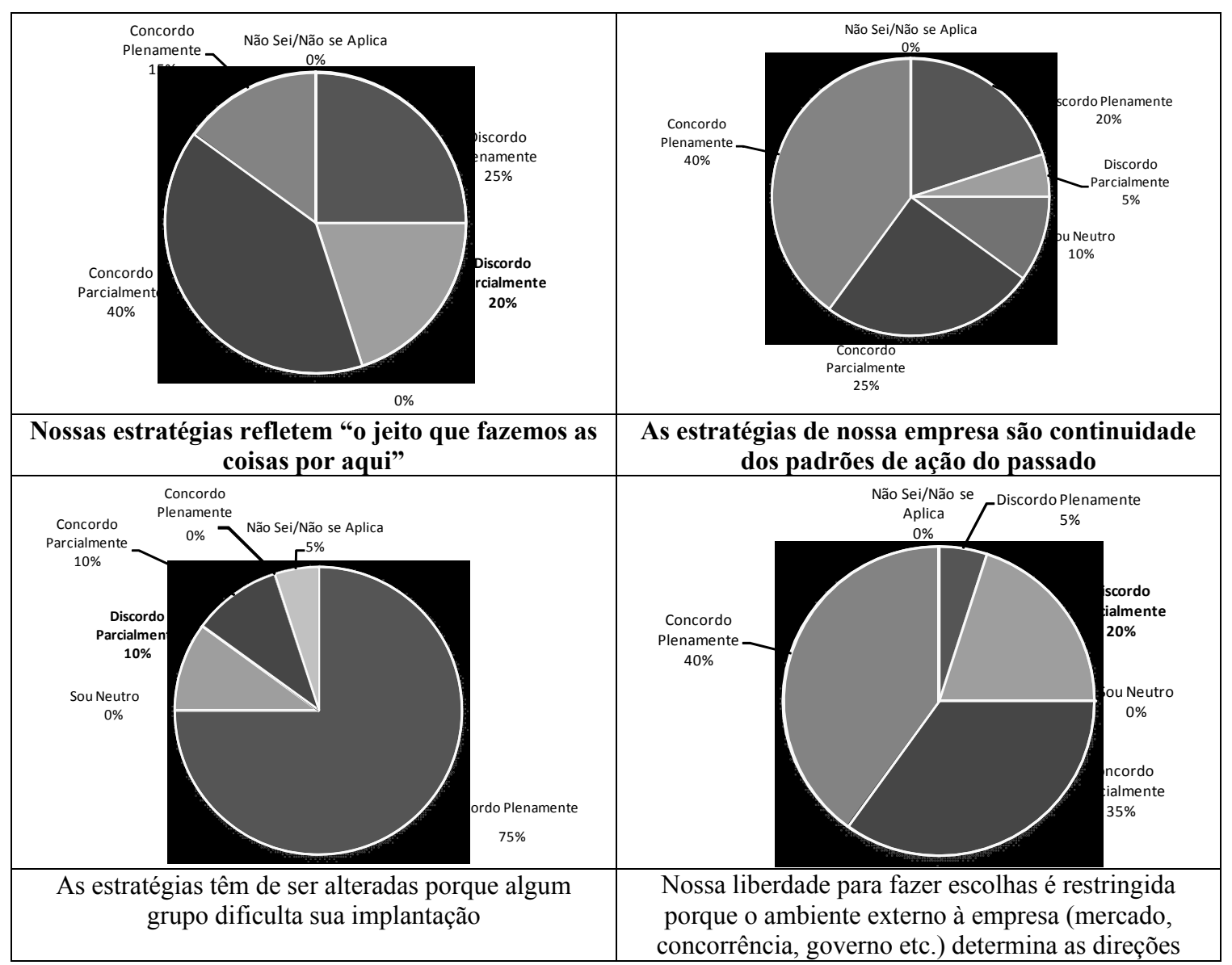

Gráfico 05: Respostas quanto ao grau de concordância às assertivas referentes a influências atitudinais (padrões do passado $x$ visão de futuro)

Fonte: elaborado pelo autor a partir de Barbero (2008)

Cada resposta foi pontuada $(-2 ;-1 ; 0 ; 1 ; 2)$ conforme o grau de concordância e "sentido" da assertiva. Foram construídos indicadores somando-se a pontuação referente a cada dimensão, mais um indicador correspondente à média destes, ajustando-se o cálculo de forma que o seu valor pode variar entre $(-10 ; 10)$. Como critério geral, pontuações positivas correspondem à 
predominância da racionalidade, da consideração dos elementos externos em relação aos internos e da visão do futuro sobre os padrões do passado; pontuações negativas, o oposto.

Quadro 13: Critérios para construção dos escores

\begin{tabular}{|c|c|c|c|c|c|c|c|c|}
\hline & & & $\begin{array}{c}\text { Discordo } \\
\text { muito }\end{array}$ & Discordo & Sou neutro & Concordo & Concordo & \\
\hline ASSERTIVAS & eixo & $\mathrm{dc}$ & & & & & & $\mathrm{cc}$ \\
\hline $\begin{array}{l}\text { As estratégias são definidas de tal forma a acomodar os diferentes interesses de } \\
\text { pessoas e grupos internos (departamentos, áreas, gerentes etc.) }\end{array}$ & AExAI & $\mathrm{AE}$ & 2 & 1 & 0 & -1 & -2 & AI \\
\hline Os interesses de um grupo de pessoas em particular dão o "tom" das estratégias & AExAI & $\mathrm{AE}$ & 2 & 1 & 0 & -1 & -2 & AI \\
\hline $\begin{array}{l}\text { Para nos manter alinhados ao nosso ambiente (externo,NdA) mudamos nossa } \\
\text { estratégia }\end{array}$ & AExAI & $\mathrm{AI}$ & -2 & -1 & 0 & 1 & 2 & $\mathrm{AE}$ \\
\hline $\begin{array}{l}\text { A maioria das mudanças estratégicas em nossa empresa ocorre por forças externas } \\
\text { (movimentação de concorrentes, novas leis, exigências dos consumidores etc.) }\end{array}$ & AExAI & AI & -2 & -1 & 0 & 1 & 2 & $\mathrm{AE}$ \\
\hline $\begin{array}{l}\text { As estratégias de nossa empresa são decididas em um processo de Planejamento } \\
\text { Estratégico }\end{array}$ & RxI & I & -2 & -1 & 0 & 1 & & $\mathrm{R}$ \\
\hline Avaliamos alternativas antes de definir as estratégias & RxI & I & -2 & -1 & 0 & 1 & & $\mathrm{R}$ \\
\hline Temos objetivos estratégicos bem definidos & RxI & I & -2 & -1 & 0 & 1 & & $\mathrm{R}$ \\
\hline $\begin{array}{l}\text { Avaliamos racionalmente nosso ambiente (externo,NdA) de negócios (concorrentes, } \\
\text { mercado etc.) }\end{array}$ & RxI & $\mathrm{I}$ & -2 & -1 & 0 & 1 & & $\mathrm{R}$ \\
\hline As estratégias têm de ser alteradas porque algum grupo dificulta sua implantação & VFxPP & $\mathrm{PP}$ & 2 & 1 & 0 & -1 & -2 & $\mathrm{VF}$ \\
\hline As estratégias de nossa empresa são continuidade dos padrões de ação do passado & VFxPP & PP & 2 & 1 & 0 & -1 & -2 & VF \\
\hline Nossas estratégias refletem "o jeito que fazemos as coisas por aqui" & VFxPP & PP & 2 & 1 & 0 & -1 & -2 & VF \\
\hline $\begin{array}{l}\text { Nossa liberdade para fazer escolhas é restringida porque o ambiente (externo,NdA) } \\
\text { externo à empresa (mercado, concorrência, governo etc.) determina as direções }\end{array}$ & VFxPP & PP & 2 & 1 & 0 & -1 & -2 & $\mathrm{VF}$ \\
\hline
\end{tabular}

Fonte: elaborado pelo autor

Tabela 03: Escores (1)

\begin{tabular}{|c|c|c|c|c|}
\hline DM & \multicolumn{4}{|c|}{ SCORES } \\
\hline Resp & RXI & AExAI & VFxPP & GERAL \\
\hline 1 & 6,25 & 1,25 & $-8,75$ & $-0,42$ \\
\hline 2 & 7,5 & 8,75 & 6,25 & 7,50 \\
\hline 3 & 2,5 & 3,75 & $-2,5$ & 1,25 \\
\hline 4 & 5 & 5 & 0 & 3,33 \\
\hline 5 & 7,5 & -5 & 0 & 0,83 \\
\hline 6 & 10 & 7,5 & 6,25 & 7,92 \\
\hline 7 & 10 & 0 & 1,25 & 3,75 \\
\hline 8 & 7,5 & 3,75 & 1,25 & 4,17 \\
\hline 9 & 0 & 10 & $-1,25$ & 2,92 \\
\hline 10 & 8,75 & 8,75 & $-3,75$ & 4,58 \\
\hline 11 & 7,5 & 3,75 & 3,75 & 5,00 \\
\hline 12 & $-8,75$ & 0 & $-1,25$ & $-3,33$ \\
\hline 13 & 1,25 & 1,25 & 1,25 & 1,25 \\
\hline 14 & 8,75 & 5 & 0 & 4,58 \\
\hline 15 & 10 & 2,5 & 3,75 & 5,42 \\
\hline 16 & 7,5 & 8,75 & 2,5 & 6,25 \\
\hline 17 & 0 & 8,75 & 1,25 & 3,33 \\
\hline 18 & 10 & 5 & $-2,5$ & 4,17 \\
\hline 19 & 10 & 0 & 1,25 & 3,75 \\
\hline 20 & 5 & 2,5 & $-7,5$ & 0 \\
\hline Moda & 7,50 & 8,75 & 1,25 & 1,25 \\
\hline MD & 7,50 & 3,75 & 0,63 & 3,75 \\
\hline MED & 5,81 & 4,06 & 0,06 & 3,31 \\
\hline DP & 4,77 & 3,91 & 3,86 & 2,75 \\
\hline
\end{tabular}

Fonte: elaborado pelo autor 
Considerando que decisões de qualidade estão relacionadas fundamentalmente a processos racionais (buscando fugir das “armadilhas' dos vieses cognitivos e das respostas emocionais) e que um aspecto fundamental da análise racional é a predominância da consideração das perspectivas, ou seja, de em que medida o futuro deverá diferir do passado, o quadro acima parece apontar o grande "vício" do gestor da EIPP. O apego a padrões do passado, sugerido pelo baixo valor do indicador correspondente, provavelmente comprometeria a qualidade das decisões, em especial em situações de mudança.

Voltando aos dados da pesquisa de Britto (2004), agora quanto às respostas às doze questões referentes à decisão de exportar, foi realizada análise semelhante à descrita acima. As respostas a cada uma das questões foram pontuadas $(-2 ;-1 ; 0 ; 1 ; 2)$ conforme indicassem orientação para o passado ou para o ambiente interno (pontuação negativa) ou para o futuro e o ambiente externo (pontuação positiva). Por exemplo, quanto à principal motivação para a internacionalização, a resposta "concordo plenamente" com a afirmativa "Precaver-se de movimentos agressivos de concorrentes no mercado global" indica orientação para o futuro e para o ambiente externo, recebendo pontuação $(+2)$ para ambos os quesitos. Somando-se a pontuação para cada empresa respondente (e ajustando o valor de $-24 ; 24$ para $-10 ; 10$ ) se obtém os escores que indicam a orientação do respondente na dimensão ambiental (interno/externo) e na dimensão atitudinal (passado/futuro).

\begin{tabular}{|c|c|c|}
\hline & $\overline{V F \times P P}$ & $\mathbf{A E} \times \mathbf{A I}$ \\
\hline Moda & $\mathbf{0 , 0 0}$ & 4,17 \\
\hline Mediana & 1,25 & 3,33 \\
\hline Médi & 1,61 & 3,26 \\
\hline Desvpd & 1,84 & 1,87 \\
\hline
\end{tabular}

Fonte: elaborado pelo autor 
O resultado parece confirmar a indicação anterior: a influência da visão de futuro mostra-se fraca. As análises sugerem que o gestor da EIPP parece acreditar que o futuro deverá, na maior medida, repetir o passado; o estudo de caso a seguir explora esta indicação. 


\subsection{Estudo de caso}

O Estudo de Caso constitui o cerne da fase de campo deste estudo. Busca-se analisar uma decisão estratégica de caráter semelhante - a redefinição da composição societária - em duas empresas (BETA e DELTA). Como se verá a seguir, as empresas apresentam algumas características semelhantes, tais como o porte, os volumes de vendas, quantidade de colaboradores e os perfis dos seus gestores (todos com formação superior e pós graduação). Por outro lado, atuam em setores e mercados muito distintos; a DELTA tem participação de capital estrangeiro, ao contrário da BETA; e as suas estruturas são bastante diferentes.

Também as circunstâncias e características dos processos decisórios em questão apresentam diferenças importantes. Enquanto na DELTA trata-se de uma negociação de cotas entre os sócios, motivada fundamentalmente pela identificação de uma oportunidade por parte do sócio-gestor brasileiro, na BETA o caso é da saída de um dos sócios, o que implica na busca de uma terceira parte que possa adquirir as suas cotas. Como se verá adiante, os sócios da DELTA compartilham uma visão de futuro bastante positiva quanto às perspectivas da empresa; já na BETA isso não ocorre.

Assim sendo, este tópico se inicia com a análise individual de cada empresa, na situação enfocada - o processo de tomada de decisão. Esta análise consiste na descrição da empresa e da situação-problema - baseada fundamentalmente em elementos levantados durante a consultoria contratada para dar apoio ao processo - e na discussão das respostas dos gestores a uma entrevista, realizada pelo próprio pesquisador. Buscou-se manter a mesma estrutura, de forma a facilitar o confronto das duas situações, que conclui este item. 


\section{A empresa BETA}

A BETA é uma indústria de produtos químicos, que fabrica produtos para atender o mercado de higiene e limpeza profissional (Limpeza Industrial e Institucional - I\&I), oferecendo linhas de produtos para Tratamento de Pisos e Hiper-concentrados, que representam cerca de $70 \%$ do volume total de vendas. Também produz e comercializa aerossóis e produtos para higiene geral, pessoal e automotiva. Foi fundada em 1987 por três sócios com atuação profissional em empresas líderes no segmento de produtos químicos para limpeza I\&I. Iniciou suas atividades em um pequeno galpão no município de Diadema e conta atualmente com sede própria de $2.400 \mathrm{~m} 2$. O período desde a data de sua fundação até 1.991 foi considerado embrionário; os seus sócios controladores não dependiam financeiramente da BETA para sobreviverem, e neste momento se definiu o seu mercado de atuação.

O período de 1.992 a 2.000 foi marcado pela grande quantidade de produtos desenvolvidos e pelo forte aumento de vendas. Nos anos 90, a BETA lançou no mercado duas de produtos que obtiveram grade sucesso de mercado, levando a um crescimento das vendas que chegou a superar os $40 \%$ ao ano. Em 2.003 a BETA teve a sua trajetória de crescimento interrompida devido à saída de um dos sócios. A compra da sua participação pelos dois sócios remanescentes limitou enormemente a capacidade de investimento da organização, tanto em na área comercial quanto em P\&D. Nesse ano, a BETA contava com um quadro de 32 colaboradores, reduzido gradativamente a apenas 12 colaboradores no final de 2007 . Os lançamentos de duas novas linhas de produtos em 2004 e 2005 não atingiram os resultados de lançamentos anteriores. Os anos de 2006 e 2007 foram marcados por oscilações nas vendas e redução geral da lucratividade, principalmente em razão do esgotamento do modelo de comercialização fortemente baseado em distribuidores. 
A BETA sempre priorizou a qualidade dos produtos e serviços e a capacitação dos seus quadros. Ao iniciar na empresa, todo vendedor e representante passa por um processo de integração e treinamento, que inclui treinamento teórico e prático com relação aos produtos. Todo este treinamento é contínuo e inclui também a prática de diretores e gerentes acompanharem rotineiramente a equipe de vendas no campo, monitorando os procedimentos de Pré-venda, Venda e Pós-venda.

Do ponto de vista da infra-estrutura a BETA possui todos os recursos de que necessita para a adequada gestão dos seus negócios; prédios e instalações próprias; sistemas informatizados e integrados em todas as suas operações; sistemas de rede de dados, internet banda larga e voz (DDR); sistemas de backup completos (banco de dados, programas e arquivos).

A empresa é tributada pelo regime do lucro presumido, todavia possui todas as demonstrações financeiras exigidas para as empresas tributadas pelo lucro real, tais como Balanços Patrimoniais, Balancetes de Verificação (sintético e analítico), DRE, etc. A BETA tem investido fortemente em controle, qualidade e capacitação gerencial. Finalizou em 2.000 a implantação do ERP Advanced Protheus (Micro-Siga) e em 2005 implantou os módulos fiscal e contábil para a gestão integrada dos seus negócios, tendo ainda obtido a Certificação ISO 9001:2000 pelo IQNET e pelo Rina em 2.003.

A empresa estabeleceu a política de só atender diretamente clientes com potencial acima de $200 \mathrm{~kg}$ de produto por pedido. O atendimento também é diferenciado conforme o ramo de atividade em (a) distribuidores e revendedores de produto de limpeza (b) empresas limpadoras e (c) clientes I\&I. Estes últimos são utilizadores finais "heavy users", tais como 
shopping centers; redes de lojas; supermercados; hospitais; colégios e universidades; indústria. Os demais clientes são atendidos via os distribuidores e revendas.

Desde 2006 tem ocorrido queda dos volumes de vendas, com a capacidade ociosa a fábrica aumentando ano a ano. Os últimos investimentos na área industrial foram realizados em 2.003 (instalações e equipamentos para o armazém de produtos acabados) e poucas mudanças ocorreram desde então. Com a queda das vendas e da lucratividade, a geração de caixa da empresa ficou comprometida, culminando com a necessidade de tomar crédito junto aos bancos a partir de Dez/2.006 para o financiamento do seu capital de giro. O perfil médio da dívida é de curto/médio prazo (inferior a 18 meses).

Concluída esta breve descrição da BETA, passa-se a analisar a situação problema abordada, ou seja, a decisão da reestruturação societária da empresa. Para tanto, é descrita abaixo a análise estratégica realizada durante a consultoria contratada para determinar o valor-base para a negociação das cotas (valluation). Esta análise, baseada no método MIRA (ver capítulo 2), oferece elementos para a compreensão tanto do contexto da empresa quanto do processo decisório em si.

Análise estratégica da situação-problema

Entende-se que a capacidade da empresa de aproveitar oportunidades e neutralizar ameaças determina suas perspectivas de resultados financeiros no tempo, o que por sua vez constitui a principal medida do seu valor. Para efeito da avaliação do valor da empresa, considerou-se que, nos próximos anos, a empresa implementará ações de mercado (CENÁRIO 1) e estratégicas (CENÁRIO 2), que deverão melhorar sensivelmente a sua posição competitiva. 
Esta análise, baseada no método MIRA, foi estruturada em Missão e Visão; Fatores Críticos de Sucesso; Análise ambiental; Análise da estratégia vigente; Expectativas: Estratégias x Tendências. Constitui um aspecto fundamental do processo decisório analisado, pois fornece as bases para a avaliação do valor da empresa, que por sua vez é um dos principais elementos da decisão de reestruturar a sociedade.

Missão e Visão:

MISSÃO DA BETA

"Fornecer soluções integradas de higiene e limpeza para o mercado institucional / industrial, compostas por produtos químicos de uso profissional, equipamentos e acessórios para aplicação, bem como serviços de consultoria, treinamento e suporte técnico permanentes, com uma das melhores relações custo x benefício do mercado, de modo que nossos clientes nos percebam como um excelente parceiro de negócios.”

\section{VISÃO DA BETA}

"Ser uma organização de valor, isto é, uma organização reconhecida por saber atender e superar as expectativas dos seus clientes, colaboradores, parceiros e proprietários.”

\section{Fatores Críticos de Sucesso}

O setor de produtos de limpeza I\&I brasileiro é caracterizado pela coexistência de empresas profissionalizadas e estruturadas - aqui incluídas algumas das principais multinacionais do setor - com uma grande quantidade de pequenos fabricantes. Enquanto as primeiras se caracterizam pela oferta de produtos de ponta, atendendo ás normas e melhores práticas do setor, estas últimas em geral buscam "combater" no mercado oferecendo aos clientes (a) produtos "similares" a preços menores e/ou (b) maior flexibilidade comercial (lotes, preços, faturamento etc.). Desta forma, os principais Fatores Críticos de Sucesso no setor são: 
- Imagem percebida pelos clientes;

- Qualidade dos produtos;

- Amplitude da linha de produtos;

- Recursos financeiros;

- Capacitação dos recursos humanos (principalmente de suporte técnico);

- Serviço de treinamento e suporte ao cliente;

- Agressividade comercial;

- Flexibilidade comercial e operacional;

- Capacidades de relacionamento e colaboração;

- Foco estratégico no segmento I\&I;

- Abrangência nacional.

Pontos Fortes e Pontos Fracos da BETA

Com embasamento nos resultados de pesquisas de satisfação realizadas junto aos clientes e nas percepções do pessoal comercial, os pontos fortes e parecem decorrer da opção da BETA de oferecer ao mercado produtos e serviços comparáveis aos dos principais players do mercado.

Os pontos fortes da BETA são:

- Qualidade (performance) dos produtos;

- Capacidade técnica de seus funcionários (qualificação e desempenho diário);

- Agilidade na entrega;

- Seriedade e responsabilidade nos compromissos assumidos;

- Atendimento ao cliente;

- Relacionamento (franco e honesto);

- Abrangência Nacional e

- Certificação ISO 9001:2000

Os pontos fracos da BETA são:

- Falta de recursos em Marketing;

- Falta de recursos em treinamento; 
- Falta relacionamento em clientes importantes;

- Falta flexibilidade nas negociações comerciais com os clientes;

- Falta flexibilidade na logística (ponto a ponto);

- Falta de produtos na linha (linha incompleta)

Conclui-se desta forma que tanto as forças quanto as fraquezas da BETA decorrem da sua estratégia de oferecer um alto nível de serviço a seus clientes, com produtos e processos certificados. Parte dos clientes não atribui valor a estas características, enquanto que os clientes mais técnicos e exigentes tendem a buscar as empresas de maior porte.

Análise ambiental

A análise ambiental considera o setor no qual a empresa está inserida e o macro-ambiente sócio econômico. Procura-se identificar as variáveis ambientais que exercem influência sobre a empresa, avaliar seu comportamento e estimar o impacto sobre o desempenho.

Análise do macro-ambiente

Nesta seção são analisadas as variáveis sócio-econômicas relevantes para a BETA. Considera-se que o desempenho da BETA seja em grande parte determinado pela evolução da demanda pelos seus produtos, associada por sua vez ao crescimento da demanda por produtos e serviços especializados de limpeza I\&I, notadamente tratamento de pisos. Aparentemente, esta evolução está associada ao nível geral da atividade econômica, que mostra tendência de elevação moderada.

Assim sendo, a análise qualitativa da influência das variáveis macro-econômicas (câmbio, juros, PIB) e populacionais (evolução da demanda) sobre a evolução do negócio da BETA 
parece apontar para a necessidade de identificar nichos de mercado que apresentem expansão superior à média nacional.

Análise setorial

A análise do setor usa o modelo das cinco forças de Porter, segundo o qual o potencial de uma empresa de produzir resultados seja determinado em grande parte pela sua capacidade de lidar com as forças relativas dos seus clientes, fornecedores e concorrentes. Além dos concorrentes atuais, deve-se levar em conta a possível entrada de novos concorrentes; e é preciso analisar a possibilidade de substituição dos produtos da empresa por produtos e/ou tecnologias diferentes. Para efeito deste estudo, analisa-se o possível comportamento destas variáveis no tempo, em termos de aumento, estabilidade ou diminuição.

O Poder dos clientes tende a crescer em função de uma forte tendência no sentido da terceirização dos serviços de limpeza I\&I, combinada com a consolidação do setor, ou seja, um número cada vez menor de empresas maiores. Os demais fatores (Poder dos fornecedores, Nível de saturação da concorrência, Facilidade de entrada de novos concorrentes, Facilidade de entrada de produtos ou serviços substitutos, Nível de interferência do governo) parecem apontar para a estabilidade.

Desta forma, a análise setorial parece apontar para uma estratégia de diferenciação em nichos específicos de clientes com exigências particulares quanto ao nível de serviço, combinando alta qualidade e flexibilidade com preços competitivos.

Análise do Ambiente Operacional 
A análise do ambiente operacional retoma a discussão desenvolvida na análise setorial, com uma abordagem mais focada na atuação cotidiana da empresa. Foram identificadas e analisadas principais variáveis referentes às relações da BETA com seus concorrentes.

O mercado de prestação de serviços de limpeza Industrial e Institucional (I\&I) constitui um negócio relativamente recente; até a década de 1970 a maioria das empresas utilizava uma equipe de limpeza própria, raramente treinada em técnicas de limpeza ou no uso de equipamentos e produtos profissionais. A terceirização alavancou o mercado de produtos e serviços profissionais, tendo surgido um grande número de novas empresas no setor, que em 2005 movimentou um valor superior a US\$ 4 bilhões, empregando mais de 600 mil pessoas em cerca de 13.000 empresas entre Prestadores de Serviços de Limpeza Ambiental, Fabricantes, Importadores e Distribuidores. Esse valor está dividido da seguinte forma: Serviços de Limpeza Ambiental US\$ 3 a 3.5 bilhões; Fornecedores em geral, US\$ 700 a 800 milhões, incluindo aqui o refaturamento dos distribuidores do segmento.

Análise da estratégia vigente

A análise da estratégia vigente visa identificar as linhas-mestras da atuação da empresa, ou seja, as formas que a empresa escolheu para gerar valor. Foram identificadas as seguintes opções estratégicas:

- A BETA adota uma estratégia geral de diferenciação, oferecendo produtos de qualidade e alto nível de serviço aos clientes. Esta estratégia é sustentada por três pilares conceituais:

- gestão profissionalizada, baseada em processos certificados e integrados e com sistema ERP (Microsiga) totalmente implementado;

- absoluto respeito à legislação, tanto do ponto de vista técnico (normas sanitárias) quanto fiscal, financeiro, trabalhista e outras aplicáveis; 
- total rigor no cumprimento dos compromissos assumidos com clientes, fornecedores, colaboradores e outros parceiros

- A BETA atua de forma social e ambientalmente responsável e sustentável, buscando ainda a excelência em todos os seus processos de negócios.

- A BETA tem buscado atuar principalmente em nichos de mercado nos quais a competição se mostra mais baseada em aspectos técnicos e de nível de serviço do que na guerra de preços, sendo o principal o de produtos para tratamento de pisos.

Assim sendo, a análise da estratégia vigente da BETA mostra que a empresa tem adotado uma estratégia de diferenciação, o que em geral exige uma combinação de investimentos em P\&D e Marketing. Estes investimentos têm sido reduzidos nos últimos anos (segundo informações dos próprios gestores), sendo esta uma das possíveis causas do desempenho insatisfatório da empresa neste período.

O foco nos canais de distribuição mais longos - distribuidores e revendedores - também parece conduzir a uma situação de redução geral de margens de lucro combinada com a gradual redução de volumes em função do acirramento da concorrência. Aparentemente, a empresa deveria voltar seus esforços aos canais mais curtos - empresas limpadoras / prestadoras de serviços e clientes finais, nos quais poderia obter a recuperação de margens, ainda que com possível redução dos volumes e do ticket médio e maior demanda por serviços de apoio ao cliente.

\section{Expectativas: Estratégias x Tendências}

A avaliação da BETA foi desenvolvida em paralelo com uma consultoria que visou indicar alternativas estratégicas para que a BETA volte a colher resultados positivos da sua atuação de mercado. Conforme já citado acima, esta consultoria explorou as possibilidades de 
ampliação das receitas da empresa, fundamentalmente via ações de mercado que foram caracterizadas nos seguintes cenários estratégicos:

- Cenário 0: considerando o nível atual de atuação comercial da empresa (que indica tendência de receitas decrescentes), no cenário 0 o valor da empresa corresponde ao seu valor contábil ou de liquidação. Este cenário corresponde à alternativa estratégica de liquidar o negócio de imediato, pelo valor dos ativos físicos (principalmente imóveis).

- Cenário 1: consideram-se aqui as possibilidades de ações comerciais disponíveis para a empresa, envolvendo iniciativas de expansão de mercado sem alterações significativas na linha atual de produtos (novos clientes no setor de Limpeza I\&I e/ou em setores correlatos, tais como EPIs, químicos diversos e outros). Este cenário corresponde à alternativa estratégica de buscar uma melhora incremental dos resultados de vendas e da lucratividade.

- Cenário2: aqui são analisadas as possibilidades de ações estratégicas da empresa, envolvendo iniciativas inovadoras que podem incluir novas linhas de produtos / serviços e/ou novos negócios, tais como o provimento de soluções integradas de limpeza I\&I / tratamento de pisos a utilizadores finais destes serviços. Este cenário corresponde à alternativa estratégica de reestruturar totalmente o negócio a médio prazo, o que exigiria investimentos consideráveis, possivelmente por parte de um novo sócio e/ou investidor.

A metodologia aplicada parte da análise da situação atual da empresa e do seu ambiente de negócios para estabelecer um cenário referencial para a sua atuação nos próximos anos. Entende-se que a capacidade da empresa de aproveitar oportunidades e neutralizar ameaças determina suas perspectivas de resultados financeiros no tempo, o que por sua vez constitui a principal medida do seu valor. Após essas análises foram construídos os Cenários Referenciais com projeções entre os anos 2008 e 2012 - horizontes de planejamento 
considerado - e depois as projeções do período de Regime, considerando a perpetuidade da empresa, nos três cenários supracitados.

O método utilizado para a avaliação do valor da BETA, devido às considerações de que [a] a empresa gera renda, [b] possui ativos tangíveis inferiores a essa geração de renda e [c] possui série histórica de dados, possibilitando assim uma projeção dos fluxos de caixa, foi do Método de Fluxo de Caixa Descontado. Dada a imprevisibilidade nas projeções, foram estimados 100 valores possíveis - por meio da geração de combinações aleatórias de valores conservadores e arrojados de cada variável, como PIB, Inflação e Receitas - utilizando-se a técnica de Monte Carlo. A descrição detalhada do método é apresentada nos anexos.

O processo decisório estratégico

O processo decisório estratégico em questão, a reestruturação societária da BETA, pode ser estudado a partir da questão de pesquisa - Como os sócios-gestores das EIPPs tomam decisões estratégicas? - assim subdividida:

- Como os sócios-gestores das EIPPs identificam questões estratégicas - em termos de situação inicial e situação desejada - e como geram alternativas estratégicas?

- Quais fatores os gestores das EIPPs consideram para (a) definir os critérios de escolha, (b) confrontar os fatores e critérios conflitantes (trade-offs) e finalmente (c) escolher a alternativa estratégica a ser implementada?

- Quais são os principais fatores a influenciar o processo decisório?

- Qual o papel e a importância relativa dos processos racionais e intuitivos na escolha de alternativas estratégicas?

A descrição acima fornece os primeiros elementos para endereçar estas questões no caso em foco. Para a discussão inicial dos elementos pesquisados, é conveniente acrescentar um resumo das respostas dos gestores ao questionário (ver quadro ao final deste item). Optou-se 
por apresentar as transcrições das principais sentenças das respostas dos entrevistados a cada uma das questões, que fornecem as bases para as reflexões a seguir.

Esta decisão - a reestruturação societária da BETA - foi tomada a partir de um conjunto de informações quanto ao desempenho da empresa, disponíveis em relatórios gerenciais estruturados, que configuraram a situação inicial: lucratividade insatisfatória em função de resultados de vendas insuficientes, com tendência negativa. A situação desejada é claramente a recuperação das vendas e da lucratividade. As alternativas estratégicas foram geradas a partir de reflexões e discussões; todavia, aparentemente não houve uma análise única de uma lista de alternativas, mas sim tentativas sucessivas de resolver o problema por meio de iniciativas que se iniciaram com ações normais de vendas e marketing. O fracasso de cada iniciativa levou a uma tentativa mais "radical", e assim sucessivamente até a decisão de reestruturar a sociedade.

Quanto aos fatores considerados, as respostas de ambos os gestores indicam uma combinação de aspectos ligados à situação objetiva da empresa (racional, quantitativo) com questões de caráter pessoal (família, relacionamento pessoal dos sócios, etc.) e emocional (como o sentimento de frustração expresso por um dos gestores). Aparentemente, apenas em determinadas situações (tais como nas reuniões com a consultoria) houve uma preocupação em explicitar estes fatores; e sempre de forma parcial, ou seja, em nenhum momento se verifica a consideração sistemática de uma lista abrangente dos fatores envolvidos.

Quanto às influências, destacam-se os aspectos pessoais e emocionais. Em particular, cabe salientar as diferentes interpretações do passado dos dois gestores. Lembrando que a empresa passou por um período de resultados excelentes (até 2003), seguido de um período mais 
recente de resultados negativos (principalmente a partir de 2005), o sócio A. parece convencido da possibilidade da retomada dos bons resultados, enquanto M. demonstra-se convicto da manutenção da tendência mais recente de resultados negativos. O sócio A. mostra conviçção de que a estrutura organizacional da BETA lhe proporciona condições de voltar a obter resultados favoráveis; já M. considera que, dada a situação atual do ambiente de negócios da empresa, a reversão do quadro atual mostra-se muito difícil. Esta discussão será retomada e aprofundada no próximo capítulo.

Quadro 16: Resumo das respostas ao questionário

\begin{tabular}{|c|c|c|}
\hline Questão & Respostas - sócio A. & Respostas - sócio M. \\
\hline $\begin{array}{l}\text { 1) Por favor, cite uma } \\
\text { decisão estratégica - ou seja, uma } \\
\text { decisão muito importante, bastante } \\
\text { complexa e muito difícil de reverter - } \\
\text { tomada recentemente. Esta decisão } \\
\text { foi tomada por consenso, fruto de } \\
\text { discussão e negociação? Ou foi } \\
\text { individual? }\end{array}$ & $\begin{array}{l}\text { A decisão de mudar a } \\
\text { composição societária, com a saída } \\
\text { do sócio... } \\
\text { A resposta não é simples. } \\
\text { Não se deu de forma estruturada, } \\
\text { houve um processo de } \\
\text { amadurecimento... } \\
\text { Após várias tentativas } \\
\text { infrutíferas de reverter situação } \\
\text { negativa... foi um processo lento, por } \\
\text { mais de dois anos... ( até que houve) } \\
\text { uma conversa mais voltada a uma } \\
\text { saída mais radical em 2006, com a } \\
\text { tomada de decisão final em } 2007 . \\
\text { O sócio estava muito } \\
\text { desgastado com tentativas de } \\
\text { reverter quadro adverso de vendas... } \\
\text { tirando lado comercial, operações } \\
\text { sem problema (produção gestão, } \\
\text { sistema da qualidade). } \\
\text { Um sócio decidiu de forma } \\
\text { mais racional o outro de forma } \\
\text { emocional... a decisão de mudar a } \\
\text { composição societária, com a saída } \\
\text { do sócio M., levou à decisão de fazer } \\
\text { o BV (business valluation), que } \\
\text { levou à decisão de buscar nova } \\
\text { estrutura da capital - novo sócio e/ou } \\
\text { investidor. }\end{array}$ & $\begin{array}{l}\text { A decisão é muito mais } \\
\text { pessoal, a decisão é minha de sair } \\
\text { da sociedade... ainda nem está } \\
\text { certo como vamos fazer, } \\
\text { precisamos achar um modo. } \\
\text { No decorrer dos últimos } 3 \\
\text { a } 5 \text { anos, eu tenho vontade de fazer } \\
\text { qualquer outra coisa... Eu fui } \\
\text { desacreditando deste mercado, é } \\
\text { uma situação de desencanto. } \\
\text { O M. tomou uma decisão } \\
\text { pessoal que resultou na decisão } \\
\text { estratégica de redefinir } \\
\text { sociedade. } \\
\text { Agente depende } \\
\text { financeiramente da empresa, não } \\
\text { posso simplesmente sair... eu já } \\
\text { queria ter saído, mas eu não quero } \\
\text { que a empresa acabe. } \\
\text { Existe oportunidade no } \\
\text { mercado, mas hoje eu não ponho } \\
\text { mais uma ficha nisso... é o } \\
\text { desencanto e a infelicidade que eu } \\
\text { sinto neste negócio, eu perdi o } \\
\text { élan... eu não quero mais isso } \\
\text { independente do resultado, eu já } \\
\text { teria saído há dois anos. }\end{array}$ \\
\hline
\end{tabular}




\begin{tabular}{|c|c|c|}
\hline $\begin{array}{l}\text { 2) Como esta decisão } \\
\text { estratégica foi tomada? Houve um } \\
\text { processo formal baseado em objetivos } \\
\text { estratégicos bem definidos e na } \\
\text { avaliação meticulosa de várias } \\
\text { alternativas? As informações } \\
\text { relevantes para as decisões } \\
\text { estratégicas foram disponibilizadas de } \\
\text { maneira formalizada e estruturada? } \\
\text { Foram usados métodos quantitativos } \\
\text { para analisar as diversas alternativas, } \\
\text { ou a decisão foi tomada mais com } \\
\text { base em experiência e "feeling"? }\end{array}$ & $\begin{array}{l}\text { Um mix (entre dados e } \\
\text { feeling) dados de vendas } \\
\text { (racionalidade) e questões pessoais } \\
\text { Dados (de vendas) muito } \\
\text { estruturados e disponíveis, em forma } \\
\text { de relatórios gerenciais }\end{array}$ & $\begin{array}{l}\text { Estou convencido de que } \\
\text { o futuro (neste mercado) vai ser } \\
\text { fundamentalmente igual ao } \\
\text { passado... ainda é o Gerson (levar } \\
\text { em vantagem) que está lá... } \\
\text { Eu vivi intensamente este } \\
\text { mercado, } \\
\text { isso não é de agora, eu fui } \\
\text { me decepcionando, eu acho que } \\
\text { em outro mercado poderia ser } \\
\text { diferente. } \\
\text { Eu quero ter um pouco } \\
\text { mais de tempo, trabalhar menos, }\end{array}$ \\
\hline $\begin{array}{l}\text { 3) Ainda sobre como esta } \\
\text { decisão estratégica foi tomada: } \\
\text { mesmo que o processo não tenha sido } \\
\text { totalmente formalizado, foi seguida } \\
\text { uma seqüência? Por exemplo, o } \\
\text { problema, pesquisar alternativas, } \\
\text { definir critérios, analisar alternativas, } \\
\text { escolher e implementar a alternativa } \\
\text { melhor em termos dos critérios? }\end{array}$ & $\begin{array}{l}\text { Houve uma seqüência } \\
\text { bastante definida de identificar } \\
\text { problema, alternativas... (e) } \\
\text { momentos "de vamos rever"... } \\
\text { Desde a saída do 3o sócio, } \\
\text { várias tentativas de estruturar as } \\
\text { vendas de uma ou outra forma... } \\
\text { (percebemos que) não (eram) estas } \\
\text { as ferramentas das mudanças... } \\
\text { No final de 2007, chegou à } \\
\text { conclusão de que não dava mais para } \\
\text { continuar... a partir da falta de } \\
\text { motivação, não havia mais como } \\
\text { manter a situação... } \\
\text { Do ponto de vista humano, } \\
\text { não houve atrito, houve } \\
\text { compreensão do momento difícil... } \\
\text { no final de } 2007 \text {, tomamos a decisão } \\
\text { de fazer a saída do sócio da forma } \\
\text { menos traumática possível... } \\
\text { Na 1a etapa, contratar uma } \\
\text { consultoria de BV para estabelecer o } \\
\text { valor justo para a empresa... }\end{array}$ & $\begin{array}{l}\text { viajar... eu preciso ter uma } \\
\text { atividade que me de alguma } \\
\text { tranqüilidade... } \\
\text { Eu não tenho } \\
\text { planejamento, tudo o que eu estou } \\
\text { falando é sentimento e } \\
\text { necessidade... Posso montar uma } \\
\text { imobiliária, ou no mínimo ser } \\
\text { correto de imóveis... Eu precisaria } \\
\text { ganhar alguma coisa, mas fazer } \\
\text { meu tempo, meu horário... estou } \\
\text { pensando em uma empresa } \\
\text { imobiliária para agenciar negócios } \\
\text { de certa importância, fazer poucos } \\
\text { negócios por ano... } \\
\text { Em 1992, houve um } \\
\text { acidente comigo e eu redefini a } \\
\text { minha vida, descobri que ser feliz é } \\
\text { estar com a família,... não é só } \\
\text { grana, você tem que ter coisas que } \\
\text { te fazem feliz, dinheiro é meio. Eu } \\
\text { acho que tenho mais do que }\end{array}$ \\
\hline $\begin{array}{l}\text { 4) Em que medida esta } \\
\text { decisão estratégica representou uma } \\
\text { continuidade de padrões de ação do } \\
\text { passado - ou seja, "o jeito que } \\
\text { costumamos fazer as coisas por } \\
\text { aqui'? }\end{array}$ & $\begin{array}{l}\text { A decisão final de mudar a } \\
\text { composição societária reflete uma visão } \\
\text { de um futuro fundamenta/e diferente do } \\
\text { passado... porque nas longas discussões } \\
\text { (sobre o PE da empresa) abordei } \\
\text { mudanças de formato e modelo de } \\
\text { negócio, vislumbrando um futuro bem } \\
\text { diferente dos modelos adotados até } \\
\text { então... } \\
\text { Aí entrou o fôlego e a } \\
\text { energia necessários para mudanças } \\
\text { fortes no modelo de negócio... um } \\
\text { conjunto de decisões deste tipo, que } \\
\text { se influenciam mutuamente. } \\
\text { Lá atrás, no final de } 2006 \text { e } \\
\text { 2007, as soluções não eram tão } \\
\text { límpidas, foi um processo doloroso } \\
\text { de amadurecimento... não há como } \\
\text { separar os aspectos pessoais do dia a } \\
\text { dia dos negócios... }\end{array}$ & $\begin{array}{l}\text { preciso, embora talvez menos do } \\
\text { que eu poderia... }\end{array}$ \\
\hline
\end{tabular}




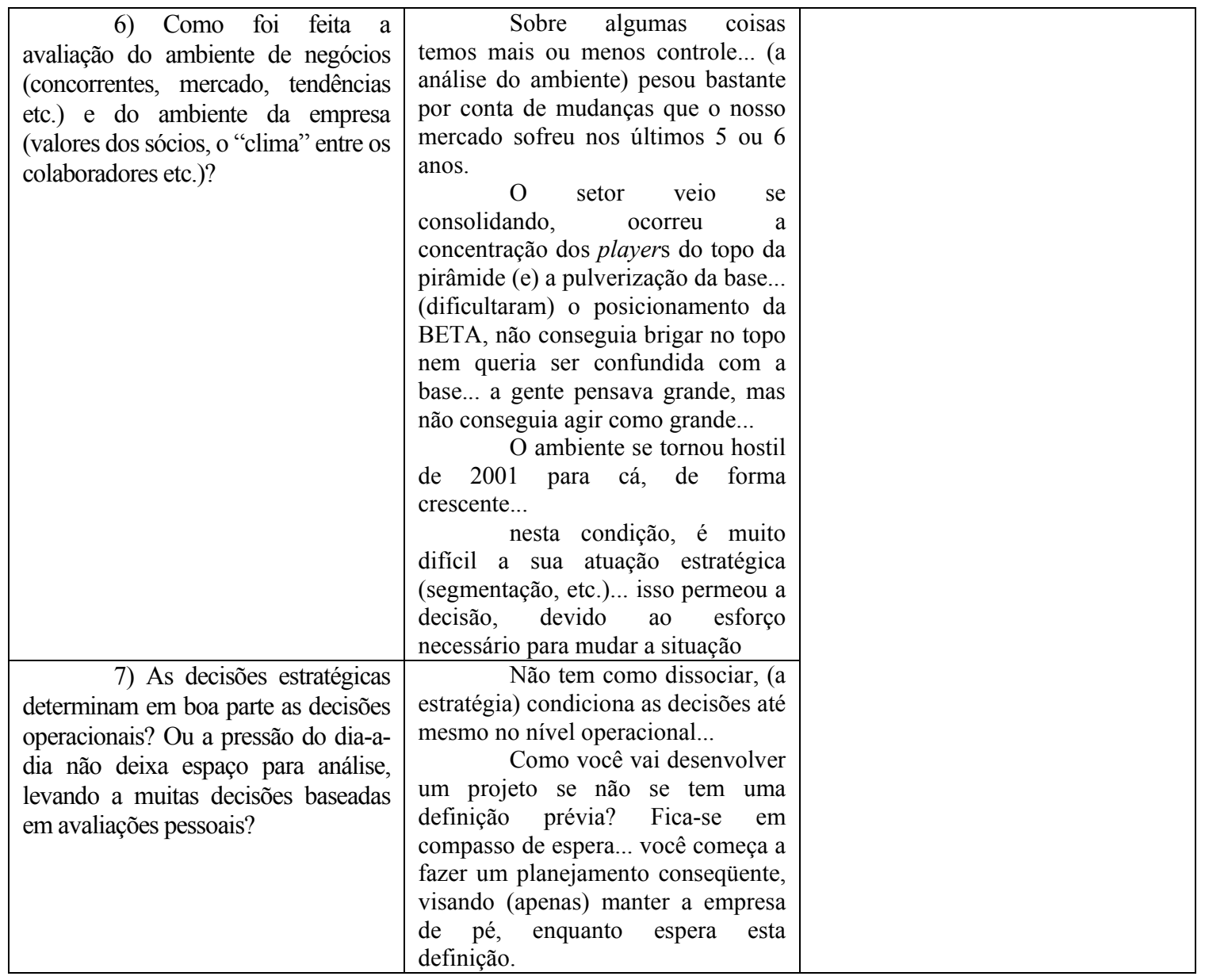

Fonte: elaborado pelo autor 


\section{A empresa DELTA}

A DELTA é a filial brasileira de uma empresa italiana produtora de robôs lineares e soluções de automação industrial, com foco na indústria de plásticos injetados. Atuando Brasil desde 1996, localizada em Diadema - SP em área de 2000m2, a DELTA já instalou mais de 500 robôs nos principais transformadores de plásticos injetados. Os clientes DELTA estão entre as principais empresas dos setores de autopeças, eletro-eletrônicos, construção civil, eletrodomésticos, móveis, utilidades etc.

A DELTA produz robôs lineares com tecnologia de ponta e oferece aos seus clientes confiabilidade, facilidade de operação, precisão e flexibilidade, com alto desempenho. A robustez e simplicidade de manutenção constituem diferenciais importantes. A fabricação local dos equipamentos proporciona duas grandes vantagens competitivas em relação a concorrentes importadores: viabiliza o financiamento via FINAME/BNDES dos equipamentos e possibilita a personalização dos projetos e atendimento de necessidades específicas dos clientes, permitindo altos níveis de serviço ao cliente.

Os principais produtos e serviços da DELTA são:

Robôs standard:

Robôs com três ou cinco eixos elétricos ou servo-controlados, para a extração de peças, separação de canal de injeção, rotulagem, inserção e aplicação de "in mould label", paletização etc. Normalmente aplicáveis com injetoras de até 600 ton..

Robôs médios:

Robôs com três eixos servo controlados, para a extração de peças, separação de canal de injeção, rotulagem, inserção e aplicação de "in mould label", paletização etc. Aplicáveis com injetoras de 600 a 850 toneladas de força de fechamento. 
Robôs especiais:

Robôs com três eixos servo controlados, para a extração de peças, separação de canal de injeção, rotulagem, inserção e aplicação de "in mould label", paletização etc. Aplicáveis com injetoras de 900 a 1400 toneladas de força de fechamento.

Peças de reposição, Serviços de manutenção e de retrofit:

Revenda de peças de reposição para o mercado em geral, serviços de manutenção de robôs DELTA fora de garantia e reforma de robôs antigos, geralmente de outros fabricantes.

Concluída esta breve descrição da DELTA, passa-se a analisar a decisão estudada - a reestruturação societária da empresa, via aumento da participação do sócio-gestor brasileiro. Para tanto, é resumida abaixo a análise estratégica realizada durante a consultoria contratada para determinar o valor-base $\left(\right.$ valluation $\left.^{3}\right)$ para a negociação das cotas. Esta análise, baseada no método MIRA (ver capítulo 2), oferece elementos para a compreensão tanto do contexto da empresa quanto do processo decisório em si.

Análise estratégica da situação-problema

A capacidade da empresa de aproveitar oportunidades e neutralizar ameaças determina suas perspectivas de resultados financeiros no tempo, o que por sua vez constitui a principal medida do seu valor. Esta análise, baseada no método MIRA, foi estruturada em Fatores Críticos de Sucesso; Análise ambiental; Análise da estratégia vigente; Expectativas: Estratégias x Tendências. Constitui um aspecto fundamental do processo decisório analisado, pois fornece as bases para a avaliação do valor da empresa, que por sua vez é um dos principais elementos da decisão de reestruturar a sociedade.

\footnotetext{
${ }^{3} \mathrm{O}$ método empregado é descrito nos anexos.
} 
Fatores Críticos de Sucesso (FCS)

- Nível de serviço ao cliente: produto flexível e fácil de usar; assessoria pré-venda, assistência no pós-venda, agilidade e flexibilidade.

- Condições de negociação: relação custo-benefício do equipamento, prazo de entrega, condições de financiamento, flexibilidade para desenvolvimentos especiais;

- Imagem de marca e rede de relacionamentos: relacionamento com fabricantes de máquinas injetoras, conhecimento de mercado, relacionamentos internacionais no setor de autopeças

Pontos Fortes: produto, serviços, flexibilidade

Pontos Fracos: custos, linha reduzida focada em produtos de tecnologia, imagem de mercado

A DELTA mostra pontos fortes importantes quanto ao atendimento das necessidades dos clientes atuais. A combinação de custos altos com imagem de mercado fraca em setores importantes como o de autopeças pode constituir uma fragilidade preocupante em um cenário de estabilização de demanda e conseqüente aumento da pressão por redução de preços, comprometendo as margens de lucro.

Análise ambiental

A análise ambiental considera o setor no qual a empresa está inserida e o macro-ambiente sócio econômico. Procura-se identificar as variáveis ambientais que exercem influência sobre a empresa, avaliar seu comportamento e estimar o impacto sobre o desempenho.

Análise do macro-ambiente

Nesta seção são analisadas as variáveis sócio-econômicas relevantes para a DELTA. Considera-se que o desempenho da DELTA seja em grande parte determinado pela evolução 
da demanda pelos seus produtos, que está associada ao crescimento da capacidade produtiva das empresas processadoras de plásticos injetados. Esta por sua vez depende da evolução da demanda de produtos de plástico, notadamente especialidades tais como peças técnicas, móveis, autopeças e outras cujo processo de fabricação demanda automação mais avançada. A atual política de juros altos e câmbio apreciado têm prejudicado a indústria em geral e os transformadores de plástico em particular. Não há perspectiva de reversão desta política, o que conduz a perspectivas negativas para a expansão da indústria de plásticos. Esta tendência é reforçada ao se analisar o comportamento e tendências da balança comercial do setor de plásticos, que vem apontando déficits crescentes. Finalmente, a política de juros aponta para a manutenção de taxas de crescimento do PIB por volta de $4 \%$ a.a..

A análise conjunta destas tendências compõe um cenário de crescimento reduzido da demanda de bens de consumo com aumento das importações, o que tende a comprometer a ampliação do parque industrial. Vale ainda salientar o possível esgotamento da expansão da demanda de bens de consumo duráveis - automóveis, eletrodomésticos etc - alavancada no passado recente pelo aumento do crédito ao consumidor, principalmente o de baixa renda. $\mathrm{O}$ crescimento das taxas de inadimplência aponta para a redução da oferta deste tipo de crédito, com conseqüente redução do crescimento das vendas de bens de consumo duráveis.

A análise qualitativa da influência das variáveis macro-econômicas (câmbio, juros, PIB) e populacionais (evolução da demanda) sobre a evolução do negócio da DELTA parece apontar para uma diminuição do ritmo de crescimento da capacidade de produção do setor de plásticos injetados (principal mercado da DELTA) a médio e longo prazo. Considerando que o aumento de capacidade produtiva da indústria ocorre normalmente por patamares - 
alternando períodos de alto investimento e de estabilidade - devem ocorrer variações anuais significativas em torno da tendência média.

\section{Análise setorial}

A análise do setor usa o modelo das cinco forças de Porter. Entende-se que o potencial de produzir resultados de uma empresa seja em grande parte determinada pela sua capacidade de lidar com as forças relativas dos seus clientes, fornecedores e concorrentes. Além dos concorrentes atuais, deve-se levar em conta a possibilidade da entrada de novos concorrentes. Finalmente, é preciso analisar a possibilidade de substituição dos produtos da empresa por produtos e/ou tecnologias diferentes. Para efeito deste estudo, analisa-se o possível comportamento destas variáveis no tempo, em termos de aumento, estabilidade ou diminuição:

- Poder dos clientes: há uma tendência de consolidação dos mercados compradores e conseqüente aumento do poder de negociação os clientes.

- Poder dos fornecedores: o poder de negociação dos fornecedores tende a diminuir, principalmente devido às possibilidades de substituição de itens (motores etc).

- Nível de saturação da concorrência: a concorrência é mediada principalmente pelo fato dos custos de substituição serem relativamente elevados, fato este que aumenta o valor da base instalada como base da vantagem competitiva. Considera-se que o nível de concorrência tende à estabilidade nos níveis atuais.

- Facilidade de entrada de novos concorrentes: o mercado brasileiro de robótica é relativamente pequeno, com poucas possibilidades de atrair grandes e/ou muitos novos players. Considera-se que o nível de concorrência tende à estabilidade nos níveis atuais.

- Facilidade de entrada de produtos ou serviços substitutos: aparentemente, a única possibilidade de substituição seriam os robôs orbitais. Considerando as características de uso e às diferenças de investimento, considera-se esta possibilidade remota, portanto a ameaça de substituição não é levada em conta. 
- Nível de interferência do governo: verifica-se uma tendência de aumento moderado da interferência do governo. Este fator pode se tornar importante se o governo vier estabelecer uma política de dificultar importações pela via do aumento da burocracia, o que poderia afetar tanto os concorrentes importadores quanto as operações de importação de componentes da DELTA.

De forma geral, nota-se uma tendência de redução de preços, devido ao aumento do poder de negociação dos clientes. Por outro lado, há também a perspectiva de redução dos custos em função da diminuição do poder de negociação dos fornecedores de alguns insumos. Parece provável uma redução das margens de lucro.

\section{Análise do Ambiente Operacional}

A análise do ambiente operacional retoma a discussão desenvolvida na análise setorial, com uma abordagem mais focada na atuação cotidiana da empresa. Foram identificadas e analisadas principais variáveis referentes às relações da DELTA com seus clientes, fornecedores e concorrentes:

- Expansão da automação industrial: As exigências de aumentar a produtividade e melhorar o controle sobre os processos industriais obrigam as indústrias a investirem em automação de processos, portanto sua expansão constitui uma tendência consolidada. Isto conduz naturalmente ao crescimento da demanda por soluções de automação, moderada pelo confronto entre os ganhos de produtividade e o custo dos investimentos.

- Custo de MO dos clientes: O custo da mão de obra é uma das variáveis importantes para a atratividade dos investimentos em automação. Aumentos nos custos relativos da mão de obra industrial, que vêm sendo identificados na indústria brasileira em geral, influenciam positivamente a demanda por soluções de automação.

- Custos de produção DELTA: A mesma tendência de aumento real dos salários na indústria, especialmente nas funções técnicas de média e alta qualificação, aponta para um aumento dos custos de produção da DELTA, com possível impacto negativo sobre as margens de contribuição. 
- Despesas DELTA: Espera-se também crescimento moderado das despesas gerais da DELTA, em função tanto do crescimento do quadro de colaboradores quanto dos salários e aumento dos gastos administrativos, tais como aluguel, tarifas etc.

A análise qualitativa das variáveis do ambiente operacional da DELTA indica um crescimento moderado da demanda, acompanhado de aumentos também moderados de gastos. Não foram identificadas tendências de acirramento da concorrência nem de forte aumento de exigências de clientes. Portanto, a análise do ambiente operacional sugere uma tendência de relativo equilíbrio entre a evolução das receitas e dos gastos da DELTA.

Análise da estratégia vigente

A análise da estratégia vigente visa identificar as linhas-mestras da atuação da empresa, ou seja, as formas que a empresa escolheu para gerar valor. Foram identificadas as seguintes opções estratégicas:

- Priorizar o controle das operações de projeto, montagem e suporte: A DELTA optou por assumir uma estrutura de gastos fixos relativos a operações de projeto, montagem dos equipamentos e suporte técnico ao cliente, priorizando o diferencial competitivo do nível de serviço e assumindo os riscos de eventuais variações de demanda.

- Focar a venda de robôs novos: A principal fonte de receitas é a venda de robôs novos. A DELTA não atua com locação de equipamentos nem com fornecimento de projetos completos (injetora + robô + serviços, por exemplo). As operações de revenda de peças e serviços de manutenção são consideradas complementares e os negócios de retrofit de equipamentos são encarados como receitas marginais, melhorando a utilização da capacidade produtiva da empresa.

- Concentrar o trabalho comercial no Diretor Geral: Boa parte dos negócios realizados pela DELTA têm sido conduzidos pessoalmente pelo Diretor-Geral, indicando ênfase no relacionamento com clientes selecionados. Em um cenário de maior quantidade de negociações com margens menores, pode se tornar de difícil sustentação e gerar desgastes com os clientes tradicionais da empresa. 
- Oferecer alto nível de serviço ao cliente: A DELTA tem atuado com a filosofia de oferecer alta qualidade de produtos e serviços a clientes selecionados (diferenciação com preço-prêmio). A continuidade do sucesso desta estratégia depende da manutenção da demanda no mercado-alvo.

- Manter o controle do suporte ao cliente: A DELTA optou por não terceirizar os serviços de suporte técnico ao cliente, o que se mostra de acordo com a sua filosofia geral de garantir alto nível de serviço aos clientes. Se viesse a se configurar um cenário de retração de demanda e/ou redução de margens, o custo da equipe interna de suporte técnico poderia se tornar um problema para a empresa.

- A análise da estratégia vigente da DELTA mostra que a empresa tem adotado uma estratégia de diferenciação baseada no desenvolvimento de soluções personalizadas e investimento em relacionamento com uma carteira selecionada de clientes. A ênfase em relacionamentos fica ainda mais evidenciada pelo fato do Diretor Geral conduzir pessoalmente as negociações, fato este que provavelmente limita as possibilidades de expansão das vendas. Desta forma, a lucratividade depende da geração de margens relativamente altas (preços prêmio).

\section{Expectativas: Estratégias x Tendências}

As considerações acima fornecem subsídios para a projeção dos resultados da DELTA receitas e gastos - no período considerado para análise (2007 a 2011 e regime). Estas projeções procuram confrontar as tendências identificadas no ambiente com as características e estratégias da DELTA e assim indicar a possível evolução dos resultados da empresa.

- Vendas para clientes tradicionais tendendo à estabilidade: Considerando que o ciclo de vida dos equipamentos é bastante longo e que a carteira de clientes é relativamente pequena, parece provável que as vendas para os clientes atuais se estabilizem nos próximos anos.

- Possibilidades de crescimento limitadas pela estrutura e política de relacionamento: A ênfase no relacionamento e serviço aos clientes combinada com uma possível consolidação do mercado aponta para limitação das possibilidades de expansão das vendas. 
- Possibilidades de exportação reduzidas em função de câmbio e custos: A combinação do Real valorizado e da alta carga tributária combinada com custos fixos relativamente elevados indica dificuldades para o crescimento das vendas através de exportações.

- Expectativa de crescimento médio das vendas próxima à evolução do PIB: A análise combinada dos fatores descritos acima aponta para uma expectativa da evolução das vendas nos próximos anos acompanhando aproximadamente a evolução do PIB.

- Oscilações em torno da média devidas ao crescimento da demanda em patamares: A expansão da capacidade da indústria tende a ocorrer em patamares, ou seja, ocorre grande aumento da demanda em certo ano, alternando-se com períodos de estabilidade. Ocorreu um pico de demanda em 2004 e o comportamento das vendas no primeiro trimestre de 2007 indica que deverá ocorrer o mesmo.

O método utilizado para a avaliação do valor da DELTA, devido às considerações de que [a]

a empresa gera renda, [b] possui ativos tangíveis inferiores a essa geração de renda e [c] possui série histórica de dados, possibilitando assim uma projeção dos fluxos de caixa, foi do Método de Fluxo de Caixa Descontado. Dada a imprevisibilidade nas projeções, foram estimados 100 valores possíveis - por meio da geração de combinações aleatórias de valores conservadores e arrojados de cada variável, como PIB, Inflação e Receitas - utilizando-se a técnica de Monte Carlo. (ver Capítulo 7: Anexos).

O processo decisório estratégico

O processo decisório estratégico em questão, a reestruturação societária da DELTA, pode ser estudado a partir da questão de pesquisa - Como os sócios-gestores das EIPPs tomam decisões estratégicas? - assim subdividida:

- Como os sócios-gestores das EIPPs identificam questões estratégicas - em termos de situação inicial e situação desejada - e como geram alternativas estratégicas? 
- Quais fatores os gestores das EIPPs consideram para (a) definir os critérios de escolha, (b) confrontar os fatores e critérios conflitantes (trade-offs) e finalmente (c) escolher a alternativa estratégica a ser implementada?

- Quais são os principais fatores a influenciar o processo decisório?

- Qual o papel e a importância relativa dos processos racionais e intuitivos na escolha de alternativas estratégicas?

A descrição acima fornece os primeiros elementos para endereçar estas questões no caso em foco. Para a discussão inicial dos elementos pesquisados, é conveniente acrescentar um resumo das respostas do gestor ao questionário (ver quadro ao final deste item). Optou-se por apresentar as transcrições das principais sentenças das respostas do gestor - o sócio brasileiro - entrevistado a cada uma das questões, nas quais se baseiam as reflexões a seguir.

Esta decisão - a reestruturação societária da DELTA, com o aumento da participação acionária do sócio minoritário, que é o gestor da operação no Brasil e AL - foi tomada a partir de um conjunto de informações quanto ao desempenho da empresa, organizadas em relatórios gerenciais semi-estruturados. A situação inicial pode ser descrita como "divisão da cotas inadequada para a máxima motivação do sócio-gestor brasileiro para o aproveitamento de um momento favorável". A situação desejada é claramente a adequação desta divisão, de forma a maximizar os resultados da unidade brasileira. Aparentemente não houve a geração de uma lista de alternativas (por exemplo, alterações no modelo de remuneração do sócio-gestor), mas sim um consenso imediato dos dois sócios - o gestor brasileiro (JL) e o controlador estrangeiro - de que deveria ser viabilizada a compra de parte das cotas pelo sócio brasileiro.

Quanto aos fatores considerados, parece ter havido, por parte de ambos os sócios, uma combinação de aspectos ligados à situação objetiva da empresa (racional, quantitativo) com uma decisão de caráter pessoal do sócio brasileiro, apoiada pelo sócio controlador 
principalmente em função do relacionamento entre ambos. Em nenhum momento parece ter havido uma análise da proposta ou pressões de qualquer tipo; ambos os sócios partiram diretamente para a viabilização da primeira e única alternativa considerada - a compra de parte das cotas do sócio controlador pelo sócio gestor.

Quanto às influências, destacam-se tanto os aspectos pessoais quanto objetivos. Em particular, cabe salientar a interpretação do passado pelo sócio-gestor (JL). Este sempre se mostrou convencido de que o futuro deverá representar a continuidade do passado. De fato, baseou nesta premissa a proposta e a sua negociação com o sócio controlador e a atuação da empresa a partir da concretização do acordo. JL afirma ainda que as projeções que embasaram o estabelecimento do valor da empresa - que por sua vez serviu de base para a negociação das cotas - vêm se cumprindo "dentro do esperado". Embora expresse alguma incerteza e preocupação quanto aos desdobramentos da crise financeira (segundo semestre de 2008 e 2009), parece acreditar na manutenção de certa "normalidade". Cabe destacar que JL afirmou que "o relatório da consultoria confirmou a idéia que ambos tínhamos sobre o valor da empresa". Aparentemente, o processo de análise (do valor da empresa) serviu fundamentalmente para reforçar uma decisão que já estava praticamente tomada. A discussão dos elementos considerados na tomada e posterior avaliação da decisão será retomada e aprofundada no próximo capítulo. 
Quadro 16: Resumo das respostas ao questionário (1)

\begin{tabular}{|l|}
\hline Questão \\
\hline 1) Por favor, cite uma decisão \\
estratégica - ou seja, uma decisão \\
muito importante, bastante \\
complexa e muito difícil de reverter \\
- tomada recentemente. Esta \\
decisão foi tomada por consenso, \\
fruto de discussão e negociação? Ou \\
foi individual?
\end{tabular}

Respostas - sócio A.

A empresa tinha 8 anos no BR, o sócio principal é uma empresa internacional. Eu era sócio minoritário e tinha vontade de ampliar a participação societária.

Por ocasião de uma visita ao BR do sócio estrangeiro, coloquei a minha intenção e por coincidência ele também já tinha intenção de fazer a mesma coisa. Acharam interessante minha proposta.

Em função de muito tempo de trabalho, bom relacionamento e amizade. Não se sabia como fazer a redistribuição das cotas: como avaliar o valor de mercado da empresa para a divisão.

Os objetivos da decisão eram mais pessoais do que em função da empresa. Era ate uma forma de mudar a remuneração e motivar o sócio minoritário.

A dificuldade era estabelecer um valor base e viabilizar o negocio. $\mathrm{O}$ 1o passo foi estabelecer uma base equilibrada e neutra para então negociar as cotas

2) Como esta decisão estratégica foi tomada? Houve um processo formal baseado em objetivos estratégicos bem definidos e na avaliação meticulosa de várias alternativas? As informações relevantes para as decisões estratégicas foram disponibilizadas de maneira formalizada e estruturada? Foram usados métodos quantitativos para analisar as diversas alternativas, ou a decisão foi tomada mais com base em experiência e "feeling"?

3) Ainda sobre como esta decisão estratégica foi tomada: mesmo que o processo não tenha sido totalmente formalizado, foi seguida uma seqüência? Por exemplo, identificar o problema, pesquisar alternativas, definir critérios, analisar alternativas, escolher e implementar a alternativa melhor em termos dos critérios?

4) Em que medida esta decisão estratégica representou uma continuidade de padrões de ação do passado - ou seja, "o jeito que costumamos fazer as coisas por aqui"? 5) Qual a importância da visão de futuro da empresa - ou seja, o rumo que se espera/deseja que a empresa tome - nesta decisão estratégica?

6) Como foi feita a avaliação do ambiente de negócios (concorrentes, mercado, tendências etc.) e do ambiente da empresa (valores dos sócios, o "clima" entre os colaboradores etc)?

7) As decisões estratégicas determinam em boa parte as decisões operacionais? Ou a pressão do dia-a-dia não deixa espaço para análise, levando a muitas decisões baseadas em avaliações pessoais?

Em função dos laços de amizade, era complicado uma parte querer avaliar a empresa... decidimos chamar um terceiro que pudesse avaliar financeiramente... o valor de mercado, usando métodos de mercado

Foi convocada uma empresa que tinha experiência... as informações foram de mercado, histórico de vendas, perspectivas em cima de dados que tínhamos aqui... dois tipos de informações: históricas (disponíveis em relatórios). (Quanto às) informações referentes ao futuro, feeling, expectativas de evolução da empresa... e informações sobre crescimento da economia e do setor.

$\mathrm{O}$ resultado do relatório forneceu uma base solida para a negociação. Confirmou a nossa expectativa, os dois sócios tinham uma idéia de valor e o relatório confirmou. A metodologia usada foi de mercado, práticas normais com estimativas sobre os dados disponíveis. Ate o momento as projeções têm se mostrado coerentes

O processo demorou bastante tempo.

Existia uma vontade, foi feito um planejamento. Houve trabalho antes de chamar a consultoria

A decisão foi estudada e administrada, não foi por impulso.

Chegou-se ao resultado desejado, um acordo satisfatório.

\section{mudança significativa.}

Foi mais baseada no histórico... Expectativas baseadas no passado...

Se tivesse ocorrido alguma grande mudança... (mas) não houve

O futuro da empresa deve ser semelhante ao passado... até este final de ano, as projeções se concretizaram.

Por algum tempo, $20 \%$ do nosso faturamento era exportação... o mercado está parado, os empresários não sabem se vão continuar a crescer...

O inicio do próximo ano deverá ser mais difícil...

Ambiente interno... nossa estrutura é pequena... as pessoas que estão no time fazem a cultura, o time olha para o mesmo lado.

São poucos funcionários, poucos níveis hierárquicos, muita agilidade

A empresa sabe como operar mesmo na minha ausência... comunicado...

Nas decisões estratégicas o sócio é consultado, em geral só discutidas.

Por ocasião das visitas a cada $3 \mathrm{a} 4$ meses, estas decisões são

Fonte: elaborado pelo autor 


\section{Análise comparada}

Dados os elementos apresentados acima, é possível perceber certas semelhanças e diferenças,

que são discutidas a seguir. Para tanto, optou-se por confrontar as respostas a cada questão, à

luz do referencial teórico e das informações sobre cada empresa e situação. Para tanto, é

apresentado um quadro para cada questão e suas respostas (já reproduzidas acima), no qual

são destacados em negrito o trechos mais significativos. Cada quadro é seguido de um

comentário, no qual os respondentes são identificados apenas pelas letras A, M e J.

\begin{tabular}{|c|c|}
\hline $\begin{array}{c}\text { Questão } \\
\boldsymbol{I}\end{array}$ & $\begin{array}{l}\text { Por favor, cite uma decisão estratégica - ou seja, uma decisão muito importante, } \\
\text { bastante complexa e muito dificil de reverter - tomada recentemente. Esta decisão foi tomada } \\
\text { por consenso, fruto de discussão e negociação? Ou foi individual? }\end{array}$ \\
\hline $\begin{array}{c}\text { BETA } \\
\text { A }\end{array}$ & $\begin{array}{l}\text { A decisão de mudar a composição societária, com a saída do sócio... } \\
\text { A resposta não é simples. Não se deu de forma estruturada, houve um processo de } \\
\text { amadurecimento... } \\
\text { Após várias tentativas infrutíferas de reverter situação negativa... foi um processo } \\
\text { lento, por mais de dois anos... ( até que houve) uma conversa mais voltada a uma saída mais } \\
\text { radical em } 2006 \text {, com a tomada de decisão final em } 2007 \text {. } \\
\text { O sócio estava muito desgastado com tentativas de reverter quadro adverso de } \\
\text { vendas... tirando lado comercial, operações sem problema (produção gestão, sistema da } \\
\text { qualidade). } \\
\text { Um sócio decidiu de forma mais racional o outro de forma emocional... a decisão } \\
\text { de mudar a composição societária, com a saída do sócio M., levou à decisão de fazer o BV } \\
\text { (business valluation), que levou à decisão de buscar nova estrutura da capital - novo sócio } \\
\text { e/ou investidor. }\end{array}$ \\
\hline $\begin{array}{c}\text { BETA } \\
\text { M }\end{array}$ & $\begin{array}{l}\text { A decisão é muito mais pessoal, a decisão é minha de sair da sociedade... ainda nem } \\
\text { está certo como vamos fazer, precisamos achar um modo. } \\
\text { No decorrer dos últimos } 3 \text { a } 5 \text { anos, eu tenho vontade de fazer qualquer outra coisa... } \\
\text { Eu fui desacreditando deste mercado, é uma situação de desencanto. } \\
\text { O M. tomou uma decisão pessoal que resultou na decisão estratégica de redefinir a } \\
\text { sociedade. } \\
\text { Agente depende financeiramente da empresa, não posso simplesmente sair... eu já } \\
\text { queria ter saído, mas eu não quero que a empresa acabe. } \\
\text { Existe oportunidade no mercado, mas hoje eu não ponho mais uma ficha nisso... é o } \\
\text { desencanto e a infelicidade que eu sinto neste negócio, eu perdi o élan... eu não quero mais } \\
\text { isso independente do resultado, eu já teria saído há dois anos. }\end{array}$ \\
\hline $\begin{array}{c}\text { DELTA } \\
\text { JL }\end{array}$ & $\begin{array}{l}\text { A empresa tinha } 8 \text { anos no } \mathrm{BR} \text {, o sócio principal é uma empresa internacional. Eu era } \\
\text { sócio minoritário e tinha vontade de ampliar a participação societária. } \\
\text { Por ocasião de uma visita ao } \mathrm{BR} \text { do sócio estrangeiro, coloquei a minha intenção e } \\
\text { por coincidência ele também já tinha intenção de fazer a mesma coisa. Acharam interessante } \\
\text { minha proposta. } \\
\text { Em função de muito tempo de trabalho, bom relacionamento e amizade. Não se } \\
\text { sabia como fazer a redistribuição das cotas: como avaliar o valor de mercado da empresa } \\
\text { para a divisão. } \\
\text { Os objetivos da decisão eram mais pessoais do que em função da empresa. Era ate } \\
\text { uma forma de mudar a remuneração e motivar o sócio minoritário. } \\
\text { A dificuldade era estabelecer um valor base e viabilizar o negocio. O 1o passo foi } \\
\text { estabelecer uma base equilibrada e neutra para então negociar as cotas }\end{array}$ \\
\hline
\end{tabular}


$\mathrm{O}$ aspecto mais destacado nesta questão é a predominância dos aspectos pessoais - o que parece refletir a interpretação dos respondentes do sentido de "individual". Os três respondentes destacam o caráter pessoal da decisão, cada qual de uma forma. A. destaca o contraste entre os sócios quanto aos aspectos de racionalidade $\mathrm{x}$ fatores emocionais, que $\mathrm{M}$. confirma. J. também dá ênfase à questão do relacionamento pessoal entre os sócios (que também está presente nas respostas de A. e M.); estas respostas antecipam boa parte dos elementos da Questão 2.

\begin{tabular}{|c|c|}
\hline $\begin{array}{c}\text { Questão } \\
2\end{array}$ & $\begin{array}{l}\text { Como esta decisão estratégica foi tomada? Houve um processo formal baseado em } \\
\text { objetivos estratégicos bem definidos e na avaliação meticulosa de várias alternativas? As } \\
\text { informações relevantes para as decisões estratégicas foram disponibilizadas de maneira } \\
\text { formalizada e estruturada? Foram usados métodos quantitativos para analisar as diversas } \\
\text { alternativas, ou a decisão foi tomada mais com base em experiência e "feeling"? }\end{array}$ \\
\hline BETA & $\begin{array}{l}\text { Um mix (entre dados e feeling) dados de vendas (racionalidade) e questões pessoais } \\
\text { Dados (de vendas) muito estruturados e disponíveis, em forma de relatórios } \\
\text { gerenciais }\end{array}$ \\
\hline BETA & $\begin{array}{l}\text { Estou convencido de que o futuro (neste mercado) vai ser fundamentalmente igual ao } \\
\text { passado... ainda é o Gerson (levar em vantagem) que está lá... Eu vivi intensamente este mercado, } \\
\text { isso não é de agora, eu fui me decepcionando, eu acho que em outro mercado poderia ser diferente. } \\
\text { Eu quero ter um pouco mais de tempo, trabalhar menos, viajar... eu preciso ter uma } \\
\text { atividade que me dê alguma tranqüilidade... } \\
\text { Eu não tenho planejamento, tudo o que eu estou falando é sentimento e necessidade... } \\
\text { estou pensando em uma empresa imobiliária para agenciar negócios de certa importância, fazer } \\
\text { poucos negócios por ano... Em 1992, houve um acidente comigo e eu redefini a minha vida, } \\
\text { descobri que ser feliz é estar com a família,... não é só grana, você tem que ter coisas que te } \\
\text { fazem feliz, dinheiro é meio. Eu acho que tenho mais do que preciso, embora talvez menos do que } \\
\text { eu poderia... }\end{array}$ \\
\hline $\begin{array}{c}\text { DELTA } \\
\text { JL }\end{array}$ & $\begin{array}{l}\text { Em função dos laços de amizade, era complicado uma parte querer avaliar a empresa... } \\
\text { decidimos chamar um terceiro que pudesse avaliar financeiramente... o valor de mercado, } \\
\text { usando métodos de mercado } \\
\text { Foi convocada uma empresa que tinha experiência... as informações foram de mercado, } \\
\text { histórico de vendas, perspectivas em cima de dados que tínhamos aqui... dois tipos de } \\
\text { informaçóes: históricas (disponíveis em relatórios). (Quanto às) informações referentes ao } \\
\text { futuro, feeling, expectativas de evolução da empresa... e informações sobre crescimento da } \\
\text { economia e do setor. } \\
\text { O resultado do relatório forneceu uma base solida para a negociação. Confirmou a } \\
\text { nossa expectativa, os dois sócios tinham uma idéia de valor e o relatório confirmou. A } \\
\text { metodologia usada foi de mercado, práticas normais com estimativas sobre os dados disponíveis. } \\
\text { Até o momento as projeções têm se mostrado coerentes }\end{array}$ \\
\hline
\end{tabular}

Novamente, pode-se notar as semelhanças e diferenças entre as respostas. A. destaca os elementos objetivos e racionais do processo decisório, ainda que reconheça a presença de 
fatores pessoais. J. traz os mesmos elementos, todavia destacando que a principal razão para se adotar uma metodologia "de mercado" foi preservar a relação entre os sócios. A resposta de M. traz diversos elementos que, embora não se refiram diretamente à questão, enriquecem as reflexões. Novamente, M. destaca aspectos pessoais (decepção, desencanto); deixa claro que tomou a decisão de afastar-se da empresa em função destes aspectos pessoais e da convicção de que o futuro (do setor de atuação da BETA) será a repetição do passado. M. levanta uma visão interessante de racionalidade, quando afirma que "[...] não é só grana, você tem que ter coisas que te fazem feliz, dinheiro é meio. Eu acho que tenho mais do que preciso, embora talvez menos do que eu poderia $[. .$.$] ”. O ganho econômico - paradigma$ fundamental da racionalidade - é visto apenas como meio de obter "felicidade"

\begin{tabular}{|c|c|}
\hline $\begin{array}{c}\text { Questão } \\
\mathbf{3}\end{array}$ & $\begin{array}{l}\text { Ainda sobre como esta decisão estratégica foi tomada: mesmo que o processo não tenha sido } \\
\text { totalmente formalizado, foi seguida uma seqüencia? Por exemplo, o problema, pesquisar alternativas, } \\
\text { definir critérios, analisar alternativas, escolher e implementar a alternativa melhor em termos dos } \\
\text { critérios? }\end{array}$ \\
\hline $\begin{array}{c}\text { BETA } \\
\text { A }\end{array}$ & $\begin{array}{l}\text { Houve uma seqüência bastante definida de identificar problema, alternativas... (e) } \\
\text { momentos “de vamos rever"... } \\
\text { Desde a saída do } 30 \text { sócio, várias tentativas de estruturar as vendas de uma ou outra } \\
\text { forma... (percebemos que) não (eram) estas as ferramentas das mudanças... } \\
\text { No final de } 2007 \text {, chegou à conclusão de que não dava mais para continuar... a partir da } \\
\text { falta de motivação, não havia mais como manter a situação... } \\
\text { Do ponto de vista humano, não houve atrito, houve compreensão do momento difícil... no } \\
\text { final de } 2007 \text {, tomamos a decisão de fazer a saída do sócio da forma menos traumática } \\
\text { possível... } \\
\text { Na la etapa, contratar uma consultoria de BV para estabelecer o valor justo para a } \\
\text { empresa... }\end{array}$ \\
\hline $\begin{array}{c}\text { BETA } \\
\text { M }\end{array}$ & $\begin{array}{l}\text { Eu vivi intensamente este mercado, isso não é de agora, eu fui me decepcionando, eu } \\
\text { acho que em outro mercado poderia ser diferente. } \\
\text { Eu quero ter um pouco mais de tempo, trabalhar menos, viajar... eu preciso ter uma } \\
\text { atividade que me dê alguma tranqüilidade... } \\
\text { Eu não tenho planejamento, tudo o que eu estou falando é sentimento e necessidade... } \\
\text { Posso montar uma imobiliária, ou no mínimo ser corretor de imóveis... }\end{array}$ \\
\hline $\begin{array}{c}\text { DELTA } \\
\text { JL }\end{array}$ & $\begin{array}{l}\text { O processo demorou bastante tempo. } \\
\text { Existia uma vontade, foi feito um planejamento. Houve trabalho antes de chamar a } \\
\text { consultoria } \\
\text { A decisão foi estudada e administrada, não foi por impulso. } \\
\text { Chegou-se ao resultado desejado, um acordo satisfatório. }\end{array}$ \\
\hline
\end{tabular}


Novamente, A. apresenta a resposta mais objetiva e coerente com o conteúdo da questão. Traz dois elementos muito importantes: a identificação da situação-problema - a queda das vendas a partir da saída do $3^{\circ}$ sócio em 2003 - e a natureza seqüencial e cíclica ("Houve uma seqüência bastante definida de identificar problema, alternativas... (e) momentos 'de vamos rever'..."), em pleno acordo com o modelo processual de Mintzberg et al (1976) descrito no Cap.2. J. também descreve sucintamente o processo, com ênfase no planejamento e deliberação e no aspecto prático do acordo concluído satisfatoriamente. A resposta de M. - na verdade, elementos já trazidos anteriormente, pois M. respondeu de forma menos ordenada e mais emocional, fazendo considerações que pouco tinham a ver com a questão em si - mostra principalmente o seu processo pessoal. É interessante notar que processos muito distintos - a análise de A. e a "crise pessoal" de M. - conduziram à mesma decisão. De forma semelhante, a decisão de J. na DELTA resultou de uma combinação de fatores objetivos com aspectos pessoais, com destaque para a preocupação de ambos os sócios (J. e o seu sócio estrangeiro) de preservar a relação pessoal e a confiança entre ambos.

\begin{tabular}{|c|c|}
\hline $\begin{array}{l}\text { Questão } \\
\qquad 4\end{array}$ & $\begin{array}{l}\text { Em que medida esta decisão estratégica representou uma continuidade de padrões de ação do } \\
\text { passado-ou seja, "o jeito que costumamos fazer as coisas por aqui"? }\end{array}$ \\
\hline $\begin{array}{l}\text { Questão } \\
5\end{array}$ & $\begin{array}{l}\text { Qual a importância da visão de futuro da empresa - ou seja, o rumo que se espera/deseja que a } \\
\text { empresa tome - nesta decisão estratégica? }\end{array}$ \\
\hline $\begin{array}{l}\text { BETA } \\
\text { A }\end{array}$ & $\begin{array}{l}\text { A decisão final de mudar a composição societária reflete uma visão de um futuro } \\
\text { fundamenta/e diferente do passado... porque nas longas discussões (sobre o PE da empresa) abordei } \\
\text { mudanças de formato e modelo de negócio, vislumbrando um futuro bem diferente dos modelos adotados até } \\
\text { então... } \\
\text { Aí entrou o fôlego e a energia necessários para mudanças fortes no modelo de negócio... } \\
\text { um conjunto de decisões deste tipo, que se influenciam mutuamente. } \\
\text { Lá atrás, no final de } 2006 \text { e } 2007 \text {, as soluções não eram tão límpidas, foi um processo } \\
\text { doloroso de amadurecimento... não há como separar os aspectos pessoais do dia a dia dos } \\
\text { negócios... }\end{array}$ \\
\hline $\begin{array}{l}\text { BETA } \\
\text { M }\end{array}$ & $\begin{array}{l}\text { Estou convencido de que o futuro (neste mercado) vai ser fundamentalmente igual ao } \\
\text { passado... }\end{array}$ \\
\hline $\begin{array}{l}\text { DELTA } \\
\text { JL }\end{array}$ & $\begin{array}{l}\text { Foi mais baseada no histórico... Expectativas baseadas no passado... } \\
\text { Se tivesse ocorrido alguma grande mudança... (mas) não houve mudaça significativa. } \\
\text { O futuro da empresa deve ser semelhante ao passado... até este final de ano, as } \\
\text { projeções se concretizaram. } \\
\text { Por algum tempo, } 20 \% \text { do nosso faturamento era exportação... o mercado está parado, os } \\
\text { empresários não sabem se vão continuar a crescer... } \\
\text { O inicio do próximo ano deverá ser mais difícil... }\end{array}$ \\
\hline
\end{tabular}


A relação entre padrões do passado e visão de futuro - e as implicações de ambos sobre as decisões - aparece nas repostas, de formas diferentes. A reposta de A. cita explicitamente "uma visão de um futuro fundamentalmente diferente do passado" - a ameaça representada pela perda de lucratividade leva à busca de alternativas "radicais", ao longo de "um processo doloroso de amadurecimento". A. está disposto a enfrentar a incerteza; já M. se mostra convencido que "o futuro vai ser fundamentalmente igual ao passado...”. Cabe a reflexão se a decisão de M. de buscar uma alternativa profissional totalmente diferente é conseqüência ou causa dessa convicção. Em outra palavras, a "certeza" de uma situação "insuportável” (o termo surgiu algumas vezes durante a entrevista) poderia ser uma forma de diminuir a angústia da incerteza quanto á nova situação profissional e econômica. Em acordo com a Teoria dos Prospectos, diante da perspectiva de perda quase certa, ambos mostram propensão ao risco. Já J. mostra desejo que o futuro repita o passado; a decisão foi tomada a partir da percepção de uma oportunidade (de ganho) - e J. mostra-se claramente "conservador", também em acordo com o sugerido pela teoria. Outro elemento importante é a confirmação pela consultoria das expectativas de ambos os sócios (já referida na questão 1).

\begin{tabular}{|c|c|}
\hline $\begin{array}{l}\text { Questão } \\
6\end{array}$ & $\begin{array}{l}\text { Como foi feita a avaliação do ambiente de negócios (concorrentes, mercado, tendências etc.) e } \\
\text { do ambiente da empresa (valores dos sócios, o "clima" entre os colaboradores etc.)? }\end{array}$ \\
\hline $\begin{array}{l}\text { BETA } \\
\text { A }\end{array}$ & $\begin{array}{l}\text { Sobre algumas coisas temos mais ou menos controle... (a análise do ambiente) pesou } \\
\text { bastante por conta de mudanças que o nosso mercado sofreu nos últimos } 5 \text { ou } 6 \text { anos. } \\
\text { O setor veio se consolidando, ocorreu a concentração dos players do topo da pirâmide (e) } \\
\text { a pulverização da base... (dificultaram) o posicionamento da BETA, não conseguia brigar no topo } \\
\text { nem queria ser confundida com a base... a gente pensava grande, mas não conseguia agir como } \\
\text { grande... } \\
\text { O ambiente se tornou hostil de } 2001 \text { para cá, de forma crescente... nesta condição, é } \\
\text { muito difícil a sua atuação estratégica (segmentação, etc.)... sso permeou a decisão, devido ao } \\
\text { esforço necessário para mudar a situação }\end{array}$ \\
\hline $\begin{array}{c}\text { BETA } \\
M\end{array}$ & $\mathrm{XX}$ \\
\hline $\begin{array}{l}\text { DELTA } \\
\text { JL }\end{array}$ & $\begin{array}{l}\text { Ambiente interno... nossa estrutura é pequena... as pessoas que estão no time fazem a } \\
\text { cultura, o time olha para o mesmo lado. } \\
\text { São poucos funcionários, poucos níveis hierárquicos, muita agilidade } \\
\text { A empresa sabe como operar mesmo na minha ausência... }\end{array}$ \\
\hline
\end{tabular}


Novamente A. confirma o seu perfil mais analítico - o que remete ao conceito de estilo cognitivo discutido no item 2.4 (estilo adaptativo $\mathrm{x}$ inovador - este último parece ser o caso de M.). Ele faz uma análise muito coerente dos elementos do ambiente que sustentam a sua convicção de que é preciso mudar o modelo de negócio da BETA (vale notar que em nenhum momento A. se mostra disposto a partir para uma situação totalmente diferente, como M. faz desde o início). M. sequer respondeu a esta questão; ficou claro que ele deixou esta análise e as decisões decorrentes - totalmente a cargo de A. A decisão de reestruturar a sociedade foi, para todos os efeitos práticos, de A. - M. apenas concordou, aparentemente ao perceber que esta decisão estava alinhada com a sua decisão pessoal já tomada de buscar uma situação profissional totalmente nova.

Também em acordo com o padrão das respostas anteriores, J. mostra-se mais pragmático e de certa foram conservador. A análise do ambiente já havia sido feita pela consultoria (em total acordo com as suas próprias percepções) e ele não se preocupa com ela. Sua resposta foca os aspectos internos, mais fazendo um check list de "coisas que poderiam dar errado" - apenas para confirmar que "está tudo certo", ou seja, que basta prosseguir no curso atual.

\begin{tabular}{|c|c|}
\hline $\begin{array}{c}\text { Questão } \\
7\end{array}$ & $\begin{array}{c}\text { As decisões estratégicas determinam em boa parte as decisões operacionais? Ou a pressão do } \\
\text { dia-a-dia não deixa espaço para análise, levando a muitas decisóes baseadas em avaliações pessoais? }\end{array}$ \\
\hline $\begin{array}{c}\text { BETA } \\
\text { A }\end{array}$ & $\begin{array}{c}\text { Não tem como dissociar, (a estratégia) condiciona as decisões até mesmo no nível } \\
\text { operacional... } \\
\text { Como você vai desenvolver um projeto se não se tem uma definição prévia? Fica-se }\end{array}$ \\
& $\begin{array}{c}\text { em compasso de espera... você começa a fazer um planejamento conseqüente, visando (apenas) } \\
\text { manter a empresa de pé, enquanto espera esta definição. }\end{array}$ \\
\hline $\begin{array}{c}\text { BETA } \\
\text { M }\end{array}$ & XX \\
\hline $\begin{array}{c}\text { DELTA } \\
\text { JL }\end{array}$ & $\begin{array}{c}\text { Nas decisões estratégicas o sócio (controlador estrangeiro) é consultado, em geral só } \\
\text { comunicado... } \\
\text { Por ocasião das visitas a cada } 3 \text { a } 4 \text { meses, estas decisões são discutidas. }\end{array}$ \\
\hline
\end{tabular}

Nesta questão, novamente ficam claras as características e prioridades de cada um dos respondentes. A. se mostra mais racional, focado no funcionamento da empresa (ambiente 
interno) e no seu futuro - que ele vislumbra diferente do passado recente. No caso de M., ele já está tão dissociado da BETA que sequer a questão chegou a ser colocada (a entrevista tomou rumo totalmente diverso). J, finalmente, mostra-se totalmente focado no dia-a-dia; aparentemente, em função do histórico recente de sucesso, ele está totalmente convencido de que a "estratégia" consiste em manter as linhas de ação atualmente em curso.

Estas reflexões são sintetizadas nas figuras a seguir, nas quais os processos analisados são apresentados em forma de fluxogramas. Notar que no caso da BETA, a "Situação desejada" é representada em cinza, para indicar que quando da conclusão deste estudo, o processo ainda não havia sido concluído. Já na DELTA, o processo estudado estava totalmente concluído. Por outro lado, a BETA “avaliou” alternativas estratégicas (na verdade, chegou a colocá-las em prática sem obter os resultados esperados), sendo que este aspecto do processo é representado no fluxograma correspondente. Vale notar que, embora houvessem alternativas disponíveis para o gestor da DELTA, aparentemente estas nunca foram realmente consideradas - sendo portanto representadas também em cinza no fluxograma. 


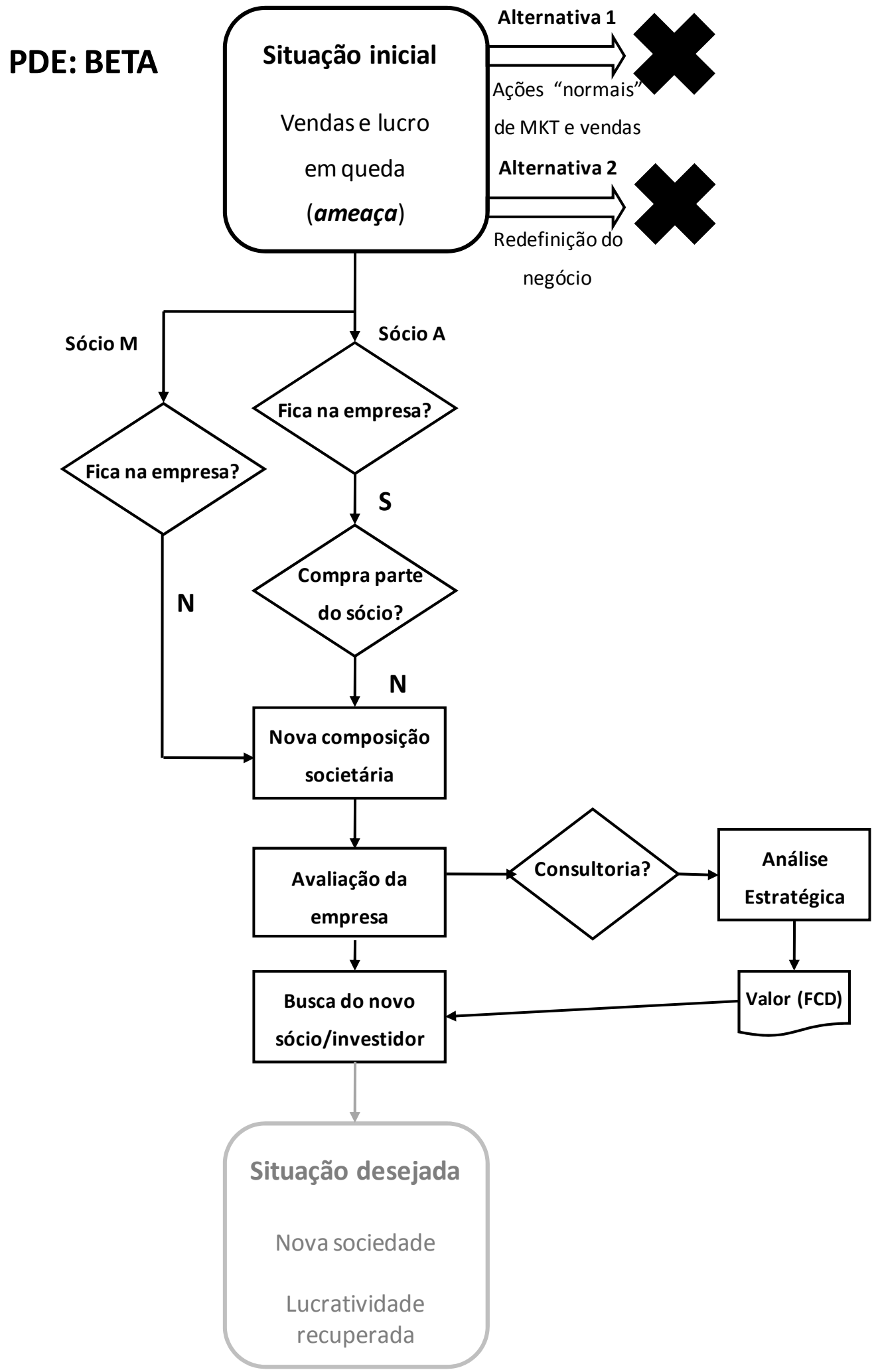

Figura 16: Representação esquemática do PDE da BETA

Fonte: elaborado pelo autor 

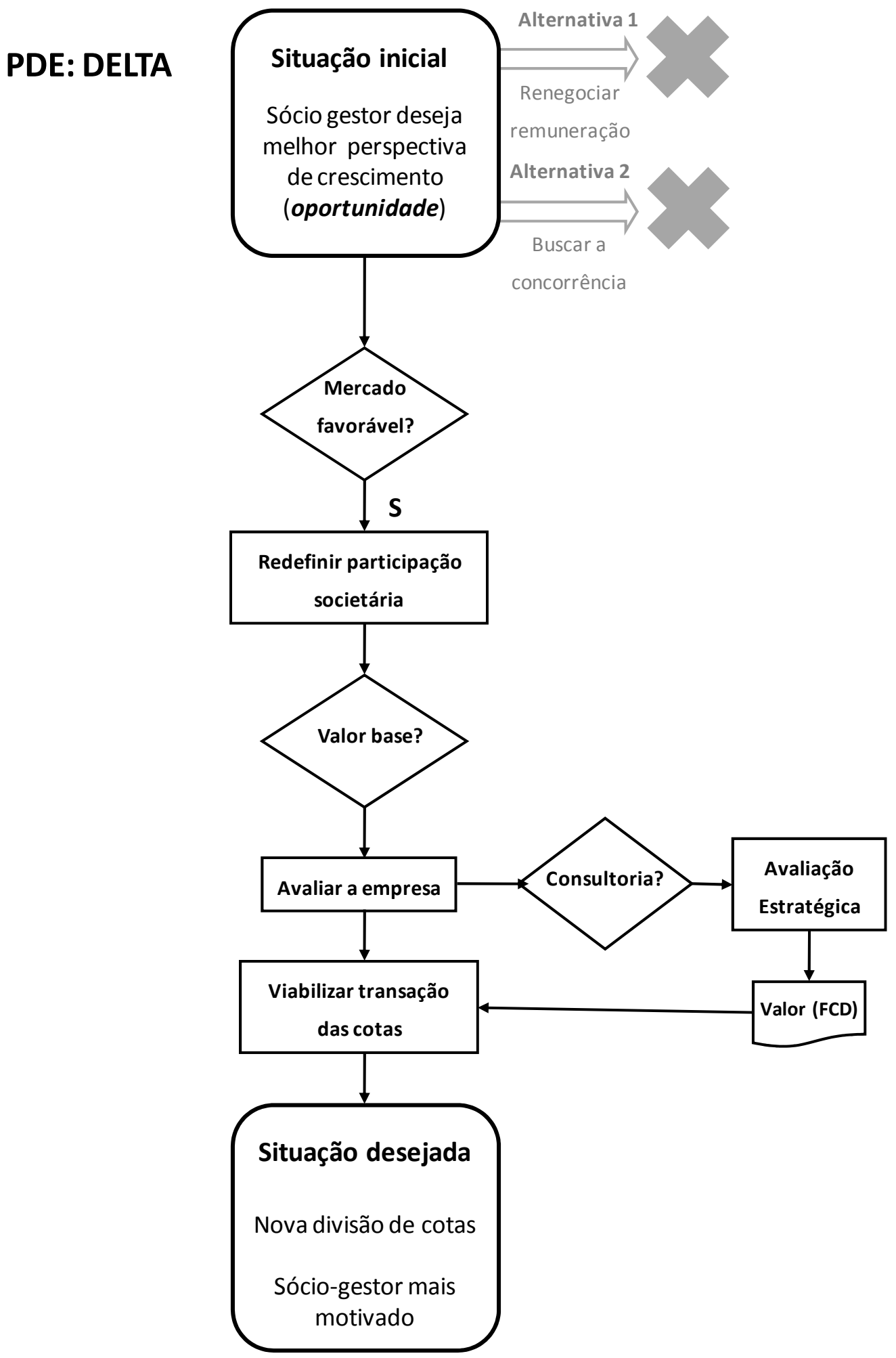

Figura 17: Representação esquemática do PDE da DELTA Fonte: elaborado pelo autor 


\section{CONSIDERAÇÕES FINAIS}

As considerações finais deste estudo buscam sintetizar as contribuições do estudo para o preenchimento das lacunas apontadas pela questão de pesquisa. Com este objetivo, neste capítulo é apresentada uma breve síntese e discussão dos resultados apresentados nos capítulos anteriores e destacadas as suas limitações destes resultados; tais limitações conduzem a recomendações para futuros estudos.

Com o objetivo de apresentar um texto mais fluido, optou-se por adotar, apenas neste capítulo, uma redação mais livre. Em especial, o sistema de referências (AUTOR, ANO) foi substituído por citações livres da conceituação apresentada pelos autores de referência. Como neste capítulo não é apresentada "informação nova", o leitor não deverá ter dificuldades para identificar as referências completas, apresentadas nos capítulos anteriores.

\subsection{Discussão dos resultados}

O presente do estudo teve por objetivo verificar como - de que forma e utilizando quais instrumentos - e por que - por quais razões e com que objetivos - os sócios-gestores das EIPPs paulistas fazem determinadas escolhas estratégicas. As implicações da discussão acima para a questão de pesquisa podem ser assim sintetizadas:

\section{Como os sócios-gestores das EIPPs tomam decisões estratégicas?}

De forma geral, os resultados indicaram que as decisões estratégicas seguem um processo, em acordo com o modelo de Mintzberg et al (1976) - identificar a situação-problema, gerar

alternativas, escolher uma alternativa. Aparentemente, a principal influência sobre esta 
escolha é constituída pelos padrões do passado. O caso estudado mostrou que o processo pode ocorrer ao longo de um período bastante longo. No caso da BETA envolveu uma demora em reconhecer claramente a situação, durante a qual se procurou reverter a situaçãoproblema identificada - lucratividade insatisfatória - com ações gerenciais "normais". O gestor da DELTA também manifesta certa resistência a reconhecer a transação de participação como estratégica. Aparentemente, existe uma tendência a minimizar a sensação de incerteza causada por decisões deste tipo.

\section{- Como os sócios-gestores das EIPPs identificam questões estratégicas - em termos de situação inicial e situação desejada - e como geram alternativas estratégicas?}

Aparentemente, a percepção da importância da decisão pode não ser imediata, mas surgir ao longo de um processo de amadurecimento da decisão. Inicialmente, a situação é vista como "de rotina" e a necessidade de decisões e ações mais "radicais" vai se evidenciando à medida que alternativas são buscadas - começando por ações de rotina - analisadas, testadas (quando possível) e descartadas.

No caso analisado, parece evidenciar-se uma diferença quanto à situação-problema constituir uma ameaça (a perda de lucratividade da BETA) ou uma oportunidade (o bom momento da DELTA). No primeiro caso, parece haver uma maior resistência em reconhecer a situação (possibilidade de perda), seguida por uma maior disposição a buscar soluções mais radicais. O caso da DELTA mostra um "salto" quase imediato para a alternativa da transação de cotas entre os sócios (possibilidade de ganhos), realizada todavia de forma a minimizar riscos e manter o padrão de operação da empresa. Estas observações mostram-se coerentes com os conceitos da Teoria dos Prospectos - aversão à perda, propensão ao risco diante da perspectiva de perdas, aversão ao risco na zona de possíveis ganhos. 
- Quais fatores os gestores das EIPPs consideram para (a) definir os critérios de escolha, (b) confrontar os fatores e critérios conflitantes (trade-offs) e finalmente (c) escolher a alternativa estratégica a ser implementada?

Aparentemente, a diminuição da expectativa de perda e da incerteza sobre o resultado "dão o tom" das escolhas. De forma geral, os gestores mostram um forte tendência a acreditar que o futuro deverá predominantemente repetir o passado - e a fazer escolhas de acordo com esta visão. Notar aqui a diferença de perspectivas dos dois gestores da BETA quanto ao futuro, em aparente contradição com a afirmação acima. Todavia, a visão pessimista de M. pode ser explicada pela projeção do passado recente de resultados negativos; enquanto a visão de A. se mostra coerente com a perspectiva da retomada do desempenho dos primeiros anos.

\section{- Quais são os principais fatores a influenciar o processo decisório?}

O perfil pessoal do decisor parece ser uma influência importante, como é evidenciado pelo estudo de caso. Na BETA, A. se mostra adaptativo e racional, convencido de que "fazer as coisas melhor" conduzirá a resultados positivos. M., mais emocional e inovativo, deseja fazer "tudo diferente" - não deseja e provavelmente não poderia optar pelas mudanças graduais, ainda que profundas, defendidas pelo sócio. $\mathrm{O}$ ambiente de negócios e mais especificamente a natureza da situação-problema parecem condicionar fortemente a atitude diante de decisão. Não surpreendentemente, mostra-se mais fácil e rápido decidir por manter uma linha de ação aparentemente vencedora do que optar por uma alternativa (entre várias) de mudança profunda de práticas que se mostram inadequadas. A atitude diante do futuro parece ser mais influenciada pelo desejo (que o passado agradável continue) e pelo medo (de que o fracasso persista) do que por uma visão de futuro construída por meio da análise objetiva do cenário julgado mais provável. 


\section{- Qual o papel e a importância relativa dos processos racionais e intuitivos na escolha de alternativas estratégicas?}

No caso analisado, os processos analíticos foram normalmente apontados como servindo de apoio e confirmação de percepções pessoais, intuitivas. Por exemplo, as percepções dos entrevistados sobre a avaliação da empresa pela consultoria mostram claramente o resultado da análise serviu principalmente para confirmar as perspectivas (baseadas em avaliações pessoais e intuitivas) do valor da empresa. Provavelmente, o maior valor dos processos analíticos esteja nos casos nos quais os seus resultados contradizem as avaliações prévias, forçando a discussão mais aprofundada tanto dos pressupostos da análise quanto da qualidade das percepções dos tomadores de decisão. De forma geral, porém, a escolha final mostra-se pessoal e intuitiva, ainda que apoiada em análises quantitativas.

\subsection{Limitações deste estudo}

Dado o caráter exploratório do estudo, seus resultados não têm potencial generalizante. Não obstante, o autor considera que os resultados oferecem contribuições válidas, especialmente para a orientação de novos estudos, dado que os dados secundários analisados constituem subconjuntos de amostras representativas do universo das empresas industriais paulistas e que o objeto do estudo de caso parece ser bastante representativo de uma parcela significativa das EIPPs paulistas.

Vale ressaltar mais uma vez que, dado que as empresas estudadas exercem suas atividades em setores estabilizados e relativamente pouco sujeitos a turbulências, empresas baseadas nas chamadas "novas tecnologias", que atuam em setores de alta complexidade e turbulência não são considerados no presente estudo. 
Foi assumido o pressuposto de que existe alinhamento entre o "melhor interesse" da empresa e do decisor; as influências dos jogos de poder e as questões de agência são consideradas pouco relevantes e não são abordadas. Embora estudos (LOURENZO, 2006, por exemplo) indiquem que certas dinâmicas presentes em empresas de base familiar (que segundo estudos do SEBRAE e outros, constituem a maioria das pequenas empresas e provavelmente parcela considerável das EIPPs paulistas) podem constituir influências semelhantes àquelas, estas questões não foram abordadas no presente estudo.

Em síntese, o presente pesquisa se baseia no pressuposto central de que nas EIPPs, tipicamente as decisões estratégicas são tomadas individualmente por um sócio-gestor que busca a racionalidade. Esta é entendida como a escolha da alternativa que proporciona os melhores resultados para a empresa - estando todavia sujeito (a) a limitações de tempo e recursos materiais e conceituais e (b) a vieses devidos seja a limitações cognitivas seja a influências emocionais, que (c) provavelmente se manifestam de forma mais severa do que no caso do executivo da grande empresa. É possível que este pressuposto central não se verifique plenamente em determinadas situações, para as quais os resultados apontados pelo estudo claramente não podem ser aplicados.

Não obstante estas limitações, este estudo deverá proporcionar uma contribuição válida para o entendimento dos processos decisórios dos gestores de pequenas empresas industriais. Em especial, o autor buscou levantar reflexões e apontar lacunas no conhecimento sobre o tematanto quanto sistematizar o conhecimento existente e contribuir para a resposta à questão de pesquisa. Tais reflexões e lacunas são discutidas no próximo item. 


\subsection{Recomendações para estudos futuros}

As limitações apontadas acima sugerem possibilidades de estudos futuros que tenham por objetivo aperfeiçoar o conhecimento sobre o processo decisório estratégico, em especial dos gestores das EIPPs paulistas. Para tanto, o autor entende ser fundamental a coordenação de esforços entre a academia e a indústria, no caso representada pela FIESP. Projetos de pesquisa em parceria entre a FIESP e pesquisadores do PPGA-FEA-USP - a exemplo da pesquisa de Britto (2004), amplamente citada neste estudo - deveriam constituir uma regra.

A própria pesquisa supracitada poderia ser transformada em pesquisa longitudinal, bem como aquela de Barbero, também supracitada. O conhecimento atualizado sobre as estratégias elaboradas e desenvolvidas pelas indústrias paulistas no contexto da economia globalizada poderia fornecer subsídios para a política industrial, programas de financiamento e outras iniciativas governamentais e/ou de outras organizações. As ferramentas proporcionadas pela Internet permitiriam estes estudos de forma dinâmica, interativa e flexível, com investimentos relativamente modestos.

O presente estudo poderia ser complementado com iniciativas que permitissem estender as análises a uma quantidade maior de empresas e seus gestores. Pela sua natureza, este estudo deveria ser realizado de forma presencial e interativa, baseando-se em entrevistas e debates. Um formato possível poderia ser a organização de seminários de pesquisa reunindo pesquisadores e empresários. Palestras, debates e sessões de focus group poderiam ser utilizadas para proporcionar troca de experiências e conhecimentos, fornecendo dados de pesquisa de alta qualidade. 
Já foi referida acima a existência de enormes massas de dados passíveis de utilização em projetos de pesquisa. Já em 2004, a pesquisa de Brito apontou que uma parcela considerável das empresas pesquisadas dispunha de sistemas ERP e outros. O uso de técnicas de data mining e business intelligence sobre as bases de dados proporcionadas por estes sistemas oferecem enormes possibilidades para projetos de pesquisa.

Propostas de métodos estruturados de apoio à decisão adequados à realidade da EIPPs também constituem um campo de estudo importante. Um método como este deveria (a) permitir ao decisor avaliar rapidamente o tipo e a importância da decisão em foco, (b) fornecer um suporte teórico ao processo de decisão e (c) proporcionar formas de avaliar a decisão, tanto a priori - a qualidade do processo decisório em si - quanto a posteriori, ou seja, o confronto entre a decisão e seus resultados. Adicionalmente, seria fundamental que este método fosse simples, no sentido de (a) envolver investimentos ao alcance da pequena empresa, (b) dispensar equipamentos e/ou plataformas de processamento sofisticadas e (c) poder ser dominado e operado pelos próprios gestores. Propostas baseadas no método MIRA (ALMEIDA, 2006) citado neste estudo provavelmente atenderiam a estes requisitos.

\subsection{Conclusões}

O presente estudo visou mais levantar reflexões do que fornecer respostas definitivas ás questões levantadas. Neste sentido, creio (o leitor me permitirá adotar a primeira pessoa nestas palavras finais) ter atingido os objetivos do estudo. A finalidade principal da pesquisa científica é aperfeiçoar o conhecimento; não obstante, os efeitos sobre o pesquisador provavelmente superem os ganhos proporcionados ao corpo de conhecimentos em si. O pesquisador que conclui este estudo pensa e vê o mundo de forma muito diferente de quando o iniciou e talvez esta nova visão seja o resultado mais importante do estudo. 
Pesquisar um fenômeno complexo e relativamente pouco conhecido envolve inicialmente buscar contato com o estado atual do conhecimento sobre o tema. A disponibilidade de material oferecida pelo uso da Internet constitui um enorme desafio, a ser enfrentado antes mesmo de se iniciar a pesquisa propriamente dita. Em poucos anos, o excesso de informação substituiu o problema eterno da sua escassez. Lidar com este novo paradigma representa um desafio para os pesquisadores de todas as áreas. A revisão "completa” do referencial teórico disponível é simplesmente impraticável; o pesquisador precisa identificar a priori o que pretende incorporar á sua pesquisa. Aparentemente, não há critérios para esta escolha - uma situação bastante semelhante à abordada no presente estudo.

Mesmo com estas limitações, revisão do referencial teórico forneceu os elementos fundamentais para o encaminhamento do estudo. O primeiro e mais central destes elementos é a visão de Mintzberg do administrador como intermediador entre a empresa e seu ambiente, a partir da qual se estabelecem os seus papéis. Decidir sobre as interações da empresa com o ambiente constitui um papel central do administrador; no caso da pequena empresa, provavelmente o principal, em especial quando a importância e irreversibilidade do comprometimento de recursos configuram uma decisão crítica para o futuro da empresa. Estas decisões estratégicas são conceituadas por Simon como não-programadas e estruturadoras. Zaccarelli as vê como problemas de passagem, similares a sistemas com mais incógnitas do que equações - várias “soluções” possíveis, como identificar “a melhor”? A decisão estratégica é sujeita à incerteza, definida incisivamente por Keynes: "Nós simplesmente não sabemos".

A resposta a esta situação lembra os koan zen; questões sem resposta que o discípulo deve “responder” mesmo assim (algo como “qual o som das palmas de uma mão só?”). Este 
"saber sem saber" pode ser chamado de intuição - uma visão imediata, quase ofuscante da "resposta". Aqui surge outro problema - como distinguir a resposta "certa" das armadilhas da mente: a racionalidade limitada, os vieses cognitivos, o "comportamento de manada"... uma longa lista de possíveis erros ou vieses, todos com uma mesma característica - aquele que escolhe não tem consciência deles e só será possível percebê-los quando produzirem seus efeitos. A mente humana analisa a realidade - átomos, galáxias, pessoas, organizações, separa e classifica, faz listas e cálculos - mas, a rigor, não pode analisar a si mesma.

Talvez por sorte, raramente nós "seres humanos suarentos e empreendedores" pensamos nestes termos - em geral, estamos ocupados em lidar com a realidade, inconscientes das dificuldades da empreitada e mais ainda das nossas limitações. Pelas leis da aerodinâmica, besouros não podem voar; eles as ignoram (duplamente) e voam assim mesmo. Os gestores das EIPPs parecem fazer algo semelhante, quando tomam decisões, as colocam em prática, eventualmente percebem que cometeram erros, redefinem trajetórias (tomam outras decisões), tentam novamente. Aparentemente, as imperfeições dos sistemas - empresas, setores, mercados - compõem um “sistema maior", talvez perfeito (outro koan?).

Os resultados do pesquisa parecem indicar que é melhor ser racional, mesmo com limitações. Aparentemente, decisões importantes sob incerteza envolvem interações sucessivas entre avaliações pessoais - por exemplo, quais fatores são relevantes para esta decisão? - e análises objetivas. Se por um lado não é possível tomar decisões sem executar um "salto intuitivo" (ou vários), parece haver evidência significativa de que não convém saltar cedo demais. É preciso buscar o melhor equilíbrio entre a análise - que é segura, mas lenta e cara - e a escolha intuitiva imediata, com a sua tremenda carga de incerteza. 
A visão do gestor sozinho, analisando a situação atual, as ameaças e oportunidades, a situação desejada e as alternativas para alcançá-la - enredado na complexidade do ambiente e nas suas próprias limitações, ao modo do Pensador de Rodin escolhido para simbolizá-lo parece-me eloqüente. Todavia, é preciso ainda incluir um elemento fundamental: o "pensador" é apenas um fotograma do filme no qual ele gestor paga e cobra duplicatas, negocia com bancos e fornecedores, recebe ficais, cuida de questões trabalhistas e resolve problemas de toda a ordem na empresa - sem falar dos pessoais e familiares! Espero que as reflexões desenvolvidas ao longo do estudo forneçam elementos para ajudar o "pensador" a desempenhar sua função fundamental de decidir com mais eficácia e menos angústia.

Assim sendo, cabe uma última reflexão quanto a esta que me parece a principal indicação fornecida por este estudo - o apego aos padrões do passado. Esta compromete as decisões ao cegar o gestor de duas formas: resposta automática e projeção cega do passado. O estudo parece indicar que a forma mais freqüente de análise "racional" envolve projetar séries de eventos passados para o futuro; é indispensável incorporar as perspectivas de mudança a esta prática. A percepção intuitiva é sujeita ao mesmo viés, pois tendemos a "esquecer" a visão clara do todo para nos deixarmos levar pelo que desejamos - ou tememos - que venha a ser a realidade futura. Aparentemente, evitar estas armadilhas depende de uma disciplina mental que precisa ser aperfeiçoada a partir da consciência destas dificuldades e limitações, por meio do estudo e prática constantes. Desenvolver e aplicar os meios para este aperfeiçoamento constitui um desafio - e um promissor campo de estudos - para pesquisadores, acadêmicos e practioners da ciência da Administração.

Provavelmente o aspecto mais central desta discussão seja o que fazer com as informações sobre o passado (disponíveis em volumes crescentes, cada vez mais confiáveis e acessíveis), 
quanto a vislumbrar possibilidades futuras - o cerne do processo decisório estratégico. Os resultados indicaram que, em geral, os gestores das EIPPs estudadas tendem a achar que o futuro deverá representar uma continuidade do passado - especialmente quando este se mostra agradável, mas também naquelas situações nas quais as forças que moldam a situação parecem desalentadoramente grandes. Desejo e medo são as duas formas fundamentais de apego ao passado - e ambos cegam aquele que procura "ver o futuro".

Em “A Arte da Guerra" Sun Tze teria afirmado que "Ver a lua no céu não é sinal de vista aguçada... ouvir o trovão não significa ter ouvido apurado." Provavelmente o texto foi mal traduzido e talvez o mítico general chinês nem tenha existido, mas se non è vero, è ben trovato; perceber os "sinais fracos" de mudança - e incorporá-los às decisões estratégicas provavelmente seja a habilidade mais importante que um gestor pode desenvolver. Se os resultados deste estudo oferecerem uma modesta contribuição neste sentido, o seu objetivo terá sido atingido. 


\section{REFERÊNCIAS}

ALMEIDA, Martinho .I.R. Manual de Planejamento Estratégico. S.Paulo. Ed Atlas, 2003.

ALMEIDA, Martinho I.R. EAD-5943- Análise do Ambiente Organizacional para o Planejamento Estratégico, notas de aula, PPGA-FEA-USP, 2006

ALMEIDA Martinho Isnard Ribeiro de, EAD-5715- Planejamento Estratégico, notas de aula, PPGA-FEA-USP, 2007

BARBERO, Edson R., Formação de Estratégias: Uma Contribuição Através de um Modelo Multidimensional, Tese de Doutorado. Faculdade de Economia, Administração e Contabilidade, Universidade de São Paulo, São Paulo, 2008

BAZERMAN, Max H., Processo Decisório, Rio de janeiro, Elsevier, 2004

BERNHOEFT, Renato. Como criar, manter e sair de uma sociedade familiar. SP: SENAC, 1996.

BILESSIMO, Luciano Dagostin. Instrumento para diagnóstico da expectativa de sucesso da micro e pequena empresa brasileira. Dissertação de Mestrado, Programa de PósGraduação em Engenharia de Produção, UFSC, Florianópolis, 2002

BORBA, José Alonso; MARTENDAL, Taise; MURCIA, DAL-RI, Fernando, Analisando o perfil das empresas familiares de pequeno porte de Santa Catarina : Um estudo múltiplo de casos, ENANPAD, 2004

BORTOLI NETO, Adelino Tipologia de problemas das pequenas e médias empresas Dissertação de mestrado, FEA-USP, Säo Paulo, 1980

BORTOLI NETO, Adelino Principais problemas das micro e pequenas empresas Revista Estudos SEBRAE, São Paulo, 1994 
BRESSAN, C. Divergências no comportamento decisório de franceses e brasileiros frente a uma decisão estratégica de sistemas de informação. Tese de Doutorado em Administração de Empresas. Escola de Administração de Empresas de São Paulo. Fundação Getúlio Vargas, São Paulo, 2004

BRITTO, R.P., Mapa da Competitividade da Indústria Paulista - Uma pesquisa sobre o potencial exportador das empresas industriais paulistas, Dissertação de mestrado, FEAUSP, Säo Paulo, 2004

CADMAN, M. H., Animal Spirits or Cold Calculation? An Introduction to Investment Appraisal, The Statistician, Vol. 22, No. 1 pp. 69-79, Blackwell Publishing for the Royal Statistical Society, London, Mar., 1973

CAIN, Bruce E.; JONES, W.T, Modes of Rationality and Irrationality, Philosophical Studies 36 (1979) 333-343. 0031-8116/79[0364-0333501.10 (versão eletrônica) D. Reidel Publishing Co., Dordrecht, Holland, and Boston, U.S.A., 1979

CLEMEN, Robert T., Making hard decisions with decisions tools, Terence Reily, 2nd edition, 2001

CORRÊA Hamilton Luis, EAD-5948 - Avaliação de Desempenho Global, notas de aula, PPGA-FEA-USP, 2006

DRUCKER, Peter,. Sociedade Pós Capitalista. São Paulo, Pioneira, 1999

EISENHARDT, Kathlenn, Building Theories from Case Study Research, Academy of Management Review, Vol 14, No 4, pgs 535-550, 1989

ESCRIVÃO FILHO, E. Pequena Empresa e Administração Estratégica: reconhecendo especificidades, restrições e facilitadores com o mapa organizacional. São Carlos: Escola de Engenharia de São Carlos, Universidade de São Paulo, Tese de Livre Docência, 2006 
FREITAS, H., MACADAR, M.A.; MOSCAROLA, J. Na busca de um método quantiqualitativo para estudar a percepção do tomador de decisão. Angra dos Reis/RJ: Anais da 20 a ENANPAD, Administração da Informação, p.253-276, 23-25 de setembro de 1996.

FRIEDMAN, T - O mundo é plano - São Paulo, Objetiva, 2005

GIMENEZ, Fernando Antonio Prado Escolhas Estratégicas e Estilo Cognitivo: Um Estudo com Pequenas Empresas - RAC, São Paulo, 1998

GIMENEZ, Fernando Antonio Prado e outros, Estratégia em pequenas empresas: uma aplicação do modelo de Miles e Snow - RAC, São Paulo, 1999

HOWARD, Ronald A; MATHESON James E, Influence Diagrams, Decision Analysis;2, 3; ABI/INFORM Global, pg. 127, Sep 2005

JOCUMSEN, Graham, Strategic marketing decision making in small business-a theoretical framework. Australian \& New Zealand Marketing Academy Conference ANZMAC 2000

KAHNEMAN, Daniel. Maps of bounded rationality. The American Economic Review, Dec, 2003

LOURENZO, Armando, Estratégias de governança na empresa familiar, Tese de Doutorado. Faculdade de Economia, Administração e Contabilidade, Universidade de São Paulo, São Paulo 2006

LI, Lei; LI, Dan DALGIC, Tevfik, Internationalization process of small and mediumsized enterprises: toward a hybrid modelof experiential learning and planning Management International Review; TX, USA, 2004

LUZ, T. Ribeiro. TELEMAR Minas - Competências que marcam a diferença. Tese (Doutorado em Administração), Belo Horizonte: UFMG/CEPEAD, 2001. 
MARCH, James G., Bounded rationality, ambiguity and the engeneering of choice, Bell Journal of Economics, 9, 1978

MARINHO , EAD-5822 - Metodologia de Pesquisa Aplicada à Administração I, notas de aula, PPGA-FEA-USP, 2006

MASON, J. Qualitative research. Beverly Hills: Sage, 1997.

MAXIMIANO, Antonio César Amaru. Introdução à Administração. S. Paulo, Atlas, 2000

MAXIMIANO Antonio César Amaru, EAD-5906 Administração de Programas e Projetos, notas de aula, PPGA-FEA-USP, 2007

MINTZBERG, Henry, The nature of managerial work, Harper \& Row, New York, 1973

MINTZBERG, Henry; RAISINGHANI, Duru, THEORET, André, The Structure of “unstructured" Decision Processes, Administrative Sciences Quarterly, vol 21, junho,1976

MORGAN, Gareth, Imagens da Organização, São Paulo, Atlas, 1996

MOTTA, Paulo, Processo decisório estratégico, Texto de apoio para cursos de pós graduação e MBAs, Rio de Janeiro, FGV, s/d

NAGELSCHMIDT, Anna Mathilde Pacheco e Chaves, PST5733 - Mapas de Realidade e Representações do Mundo Social, notas de aula, Programa de Pós-Graduação em Psicologia Social, 2007

NARESH Khatri; ALVIN H., The role of intuition in strategic decision making, Human Relations, Vol. 53, No. 1, 57-86, 2000

PAIVA, Wagner Peixoto de, Avaliação de habilidades para a tomada de decisão em administração de empresas: um estudo descritivo com alunos de graduação da FEAUSP, Dissertação de mestrado, Säo Paulo, FEA-USP, 2002 
PARIKH, J.;NEUBAUER, F.; LANK, A., Intuição: A Nova Fronteira da Admnistração, Cultrix, S.Paulo, 1998

PATTON, E.; APPELBAUM, S. H., The case for case studies in management research. Management Research News, v. 26, n. 5, p. 60-71, 2003

PMI - Project Management Institute, Guia PMBOK: Um guia do conjunto de conhecimento em Gerenciamento de Projetos, PMI Institute, edição eletrônica, 2004

PORTER, M. Estratégia Competitiva Rio de Janeiro, Campus, 1986.

RUIZ, J.A. Metodologia científica: guia para eficiência nos estudos. S. Paulo, Atlas, 1996.

SANTOS Silvio Aparecido dos, A modernização gerencial e tecnológica de micro e pequenas indústrias apoiada na cooperação entre as empresas, Tese de Livre-Docência, PPGA-FEA-USP, 1995

SANTOS Silvio Aparecido dos, EAD-5750 - Seminário de Elaboração de Estudos e Pesquisas em Administração, notas de aula, PPGA-FEA-USP, 2008

SEBRAE, Sobrevivência e mortalidade das empresas paulistas de 1 a 5 anos / Marco Aurélio Bedê, (coordenador), São Paulo, SEBRAE, 2004.

SELLTIZ, C.; JOHADA, M.; DEUTSCH, M. e COOK, S. W. Métodos de pesquisa nas relações sociais. Segunda Edição, Editora Pedagógica e Universitária: São Paulo, 1974.

SIMON, Herbert, Comportamento Administrativo, EDUSP, São Paulo, 1979

SIMON, Herbert, Reason in Human Affairs, EDUSP, São Paulo, 1982

YIN, R. K., Estudo de Casos - Planejamento e Métodos. São Paulo, Bookman Companhia Editora, 2001 
YU, Abraham, EAD-5853-Análise das Decisões na Incerteza Aplicada à Administração, notas de aula, PPGA-FEA-USP, 2008

WILSON, P. M. Strategic decision-making in a professional services firm. In: Akintoye, A (Ed.), Seventeenth Annual Conference of the Association of Researchers in Construction Management, Manchester. ARCOM, Vol. 2, 649-59, 2001

ZACCARELLI, S. B.; FISCHMANN, A.A. e LEME, R.A.S Ecologia de Empresas, Editora Atlas, São Paulo, 1980.

ZACCARELLI, Sergio B., Estratégia e sucesso nas empresas, São Paulo, Saraiva, 2000 


\section{Anexos}

\subsection{Anexo 1: Questionário da Pesquisa Survey (BARBERO, 2008)}

Por favor, leia este pequeno texto antes de responder as questões

Nesta seção há questões sobre como as estratégias de sua empresa são desenvolvidas. Chamamos de estratégia as decisões e ações que impactam toda a organização, que lidam com o mercado e competidores e que se preocupam com os resultados de longo prazo da empresa. Assim, não consideramos como estratégia as decisões de cunho operacional ou tático.

Leia as afirmativas abaixo e pontue seu grau de concordância na escala de $\mathbf{1}$ a $\underline{\mathbf{5}}$. Quanto maior a numeração, maior sua concordância com cada afirmativa

\begin{tabular}{|c|c|c|c|c|c|c|}
\hline AFIRMATIVAS & $\begin{array}{c}\text { Discordo } \\
\text { Muito }\end{array}$ & Discordo & $\begin{array}{c}\text { Sou } \\
\text { Neutro }\end{array}$ & Concordo & $\begin{array}{l}\text { Concordo } \\
\text { Muito }\end{array}$ & $\begin{array}{l}\text { Năo Sei ou năo se } \\
\text { aplica }\end{array}$ \\
\hline \multicolumn{7}{|c|}{ Deliberação x Emergência } \\
\hline As estratégias de nossa empresa são decididas em um processo de Planejamento Estratégico & () & () & () & () & () & () \\
\hline Avaliamos alternativas antes de definir as estratégias & () & () & () & () & () & () \\
\hline O principal executivo determina nossa estratégia & () & () & () & () & () & () \\
\hline Temos objetivos estratégicos bem definidos & () & () & () & () & () & () \\
\hline Para nos manter alinhados ao nosso ambiente mudamos nossa estratégia & () & () & () & () & () & () \\
\hline Desenvolvemos as estratégias através de um processo de experimentaç̃ŏ de novas abordagens & () & () & () & () & () & () \\
\hline \multicolumn{7}{|c|}{$\begin{array}{l}\text { Politico } x \text { Apolitico } \\
\end{array}$} \\
\hline áreas, gerentes etc.) & () & () & () & () & () & () \\
\hline Os interesses de um grupo de pessoas em particular dão o "tom" das estratégias & (1) & (1) & () & () & () & () \\
\hline As estratégias têm de ser alteradas porque algum grupo dificulta sua implantação & (1) & () & () & () & () & () \\
\hline \multicolumn{7}{|c|}{ Visão de Futuro x Padrōes Culturais } \\
\hline As estratégias de nossa empresa são continuidade dos padrōes de açăo do passado & () & () & () & () & () & () \\
\hline Nossas estratétegias refletem "o jeito que fazemos as coisas por aqui" & (1) & () & (1) & () & () & () \\
\hline etc.) determina as dirę̧̄oss & () & () & () & () & () & () \\
\hline \multicolumn{7}{|c|}{ Discricionaridade $\mathrm{x}$ Determinismo } \\
\hline Não temos como influenciar nosso ambiente de negócios & () & () & () & () & () & () \\
\hline leis, exigências dos consumidores etc.) & () & () & () & () & () & () \\
\hline Em nosso ramo de negócios, as mudanças são frequentes e exigem constante atualização & () & (1) & () & () & () & () \\
\hline As "regras" do nosso mercado têm se mantido estáveis (sem grandes alteraçōes tecnológicas e/ou de mercado) & () & () & () & () & () & () \\
\hline \multicolumn{7}{|c|}{ ade $x$ Intuị̄ão } \\
\hline Avaliamos racionalmente nosso ambiente de negócios (concorrentes, mercado etc.) & (1) & () & () & () & () & () \\
\hline
\end{tabular}

Por favor, leia este pequeno texto antes de responder as questões

Nesta seção colocamos questões sobre sua empresa e seu mercado. Cumpre aqui lembrar que nenhuma informação sobre sua organização será divulgada.

Cargo que ocupa:

( ) Presidência ou Proprietário

( ) Diretoria

( ) Gerência

Número de funcionários de sua empresa (em caso de empresa multinacional, considerar apenas a unidade brasileira):

() 1 a 10

() 11 a 50

() 51 a 100

() de 101 a 500

() de 501 a 750

() de 751 a 1000

() mais de 1000

Origem preponderante do capital: ( ) Nacional ( ) Multinacional

Assinale qual a faixa aproximada do faturamento bruto de sua empresa no ano 2007 (em Reais). Em caso de empresa multinacional, considerar apenas a unidade brasileira. Lembramos que nada será divulgado.

\begin{tabular}{|c|c|c|c|}
\hline ) & Menos de $50 \mathrm{mil}$ & ) & 20 Milhões \\
\hline ) & mil & ) & 50 Milhões \\
\hline ) & mil & ) & 100 Milhões \\
\hline ) & mil & ) & e 150 Milhões \\
\hline ) & mil & ) & e 250 Milhões \\
\hline ) & $\begin{array}{l}\text { Milhão } \\
\text { Entre } 1 \text { Milhão e } 2\end{array}$ & ) & $\begin{array}{l}\text { e } 500 \text { Milhões } \\
\text { Entre } 500 \text { Milhões }\end{array}$ \\
\hline ) & $\begin{array}{l}\text { Milhões } \\
\text { Entre } 2 \text { milhões e } 5\end{array}$ & ) & $\begin{array}{l}\text { e } 1 \text { Bilhão } \\
\text { Entre } 1 \text { Bilhão e } 5\end{array}$ \\
\hline ) & $\begin{array}{l}\text { Milhões } \\
\text { Entre } 5 \text { Milhões }\end{array}$ & ) & Bilhões \\
\hline ( $)$ & 10 Milhões & ) & Mais de 5 Bilhões \\
\hline
\end{tabular}

incluindo, portanto, sua empresa e seus concorrentes. Caso $\overline{\text { não saiba precisamente este valor faça, por favor, uma estimativa. }}$

Agora, indique o percentual que crescimento de sua empresa. 


\subsection{Anexo 2: Questões da Pesquisa Survey (BRITTO, 2004, com adaptações); Características Gerais e Maturidade}

\begin{tabular}{|c|c|c|}
\hline DIM & Aspectos C & ENUNCIADO \\
\hline $\mathrm{I}$ & CARGER & Qual das seguintes afirmações melhor descreve a sua área de atuação comercial? \\
\hline I & CARGER & $\begin{array}{l}\text { Qual das seguintes afirmações melhor descreve a composição de sua equipe de distribuição } \\
\text { e vendas? }\end{array}$ \\
\hline $\mathbf{I}$ & CARGER & $\begin{array}{l}\text { A taxa de crescimento de vendas da sua empresa nos últimos três anos tem sido (em } \\
\text { média): }\end{array}$ \\
\hline $\mathbf{I}$ & CARGER & $\begin{array}{l}\text { Qual a cadeia Industrial da qual sua empresa faz parte? (caso sua empresa faça parte de mais } \\
\text { de uma destas cadeias, indique aquela que é a mais representativa dentro do faturamento de } \\
\text { sua empresa): }\end{array}$ \\
\hline $\mathbf{I}$ & CARGER & $\begin{array}{l}\text { Como você classificaria o grau de concentração geográfica de empresas do seu setor na } \\
\text { região onde sua empresa está operando? }\end{array}$ \\
\hline $\mathbf{I}$ & CARGER & $\begin{array}{l}\text { Há participação de capital estrangeiro na sua empresa? De quanto? (Percentual de capital } \\
\text { estrangeiro em relação ao total) }\end{array}$ \\
\hline $\mathbf{I}$ & CARGER & $\begin{array}{l}\text { Qual a participação das exportações sobre o faturamento total de sua empresa nos } \\
\text { seguintes anos? As exportações foram: }\end{array}$ \\
\hline $\mathrm{T}$ & MATRD & Aproximadamente há quanto tempo a sua empresa está no mercado (nacional)? \\
\hline I & MATRD & $\begin{array}{l}\text { A administração financeira e orçamentária da nossa empresa tem sido realizada } \\
\text { profissionalmente há muitos anos. }\end{array}$ \\
\hline $\mathbf{I}$ & MATRD & $\begin{array}{l}\text { Nossa linha de produtos é competitiva em preços, características e benefícios quando } \\
\text { comparada às linhas das melhores empresas do mundo. }\end{array}$ \\
\hline $\mathbf{I}$ & MATRD & $\begin{array}{l}\text { Nossa empresa já ultrapassou seu estágio de consolidação no mercado brasileiro e agora se } \\
\text { encontra e num estágio maduro, de estabilidade, com administradores profissionais nas } \\
\text { posições gerenciais essenciais. }\end{array}$ \\
\hline $\mathbf{I}$ & MATRD & $\begin{array}{l}\text { Nossa empresa tem realizado suas operações em nível nacional obtendo um fluxo de caixa } \\
\text { positivo e sustentável há diversos anos. }\end{array}$ \\
\hline $\mathrm{T}$ & MATRD & Qual situação atual da empresa em relação à exportação? Atualmente a empresa: \\
\hline I & MATRD & $\begin{array}{l}\text { Nossos gastos com pesquisa e desenvolvimento são competitivos dentro dos padrões de } \\
\text { nossa indústria: }\end{array}$ \\
\hline $\mathrm{I}$ & MATRD & Nossos preços provavelmente são competitivos no mercado externo: \\
\hline I & MATRD & Nossos produtos foram projetados para atender padrões e regulamentos internacionais. \\
\hline I & MATRD & $\begin{array}{l}\text { Em termos de sistemas informatizados de apoio à gestão, sua empresa possui quais dos } \\
\text { seguintes tipos de programas de computação (pode-se marcar mais de um): }\end{array}$ \\
\hline I & PRT & $\begin{array}{l}\text { Qual é a sua participação de mercado no Brasil? (percentual das vendas da sua empresa } \\
\text { sobre o total das vendas de empresas do seu setor) }\end{array}$ \\
\hline T & PRT & Qual foi o seu faturamento bruto no último ano (2003)? \\
\hline $\mathbf{I}$ & PRT & $\begin{array}{l}\text { Quantos empregados em tempo integral a sua empresa tem? (somando registrados, } \\
\text { cooperados, autônomos, terceirizados etc.) }\end{array}$ \\
\hline II & ATTD & $\begin{array}{l}\text { Qual a disposição / aversão ao risco que a alta gerência e os proprietários têm sobre a } \\
\text { atividade de exportação? }\end{array}$ \\
\hline III & ATTD & A alta gerência visualiza a exportação da seguinte forma: \\
\hline II & ATTD & $\begin{array}{l}\text { Você pretende fazer com que as atividades de sua empresa relacionadas ao comércio } \\
\text { internacional: }\end{array}$ \\
\hline II & $\mathrm{CNHC}$ & $\begin{array}{l}\text { O seu conhecimento sobre seus competidores estrangeiros (seus produtos, suas estratégias } \\
\text { de marketing e suas práticas) é: }\end{array}$ \\
\hline II & $\mathrm{CNHC}$ & $\begin{array}{l}\text { Seu conhecimento sobre fontes de informações sobre os mercados estrangeiros potenciais } \\
\text { e sua disposição para investir na busca dessas informações é: }\end{array}$ \\
\hline II & $\mathrm{CNHC}$ & $\begin{array}{l}\text { Os principais gerentes e diretores da empresa têm domínio de pelo menos um idioma } \\
\text { estrangeiro: }\end{array}$ \\
\hline II & $\mathrm{CNHC}$ & $\begin{array}{l}\text { Gerentes e diretores da empresa passam continuamente por treinamentos de administração } \\
\text { e negociações interculturais. }\end{array}$ \\
\hline II & $\mathrm{CNHC}$ & Qual o seu nível escolaridade? (respondente): \\
\hline II & EXPR & $\begin{array}{l}\text { Os principais diretores e gerentes de nossa empresa possuem considerável experiência de } \\
\text { vida e trabalho em mercados estrangeiros. }\end{array}$ \\
\hline II & EXPR & $\begin{array}{l}\text { Os principais diretores e gerentes de nossa empresa tiveram experiências em pequenos } \\
\text { projetos mercados estrangeiros ou participaram de intercâmbios no exterior: }\end{array}$ \\
\hline II & EXPR & $\begin{array}{l}\text { Os principais diretores e gerentes de nossa empresa têm considerável experiência de } \\
\text { trabalho com facilitadores da atuação no mercado brasileiro (bancos, escritórios de direito } \\
\text { empresarial, empresas de transporte, empresas de pesquisa de mercado etc). }\end{array}$ \\
\hline
\end{tabular}




\subsection{Anexo 3: Questões da Pesquisa Survey (BRITTO, 2004, com adaptações); Decisão de exportar}

\begin{tabular}{|c|l|}
\hline III & Expandir internacionalmente para mercados-chave no mundo. \\
\hline III & Aumentar a competitividade da empresa ao adquirir mais conhecimento de mercado. \\
\hline III & Reduzir o risco da empresa através da venda em diversos mercados estrangeiros. \\
\hline III & Precaver-se de movimentos agressivos de concorrentes no mercado global. \\
\hline III & Somente para contra-balancear a sazonalidade do mercado brasileiro. \\
\hline III & Apenas para atender os pedidos do exterior que recebemos inesperadamente. \\
\hline III & Complementar as vendas nacionais com exportações ocasionais. \\
\hline III & Manter nossos produtos em linha durante um maior número de anos através da exportação. \\
\hline III & Explorar a tecnologia e o "know-how" únicos da nossa empresa. \\
\hline III & Melhorar o retorno sobre o investimento de longo prazo da empresa. \\
\hline III & Contribuir para a expansão da empresa no longo prazo. \\
\hline III & Reduzir estoques excessivos e/ou utilizar o excesso de capacidade produtiva. \\
\hline
\end{tabular}




\subsection{Anexo 4 - Questionário do Estudo de caso}

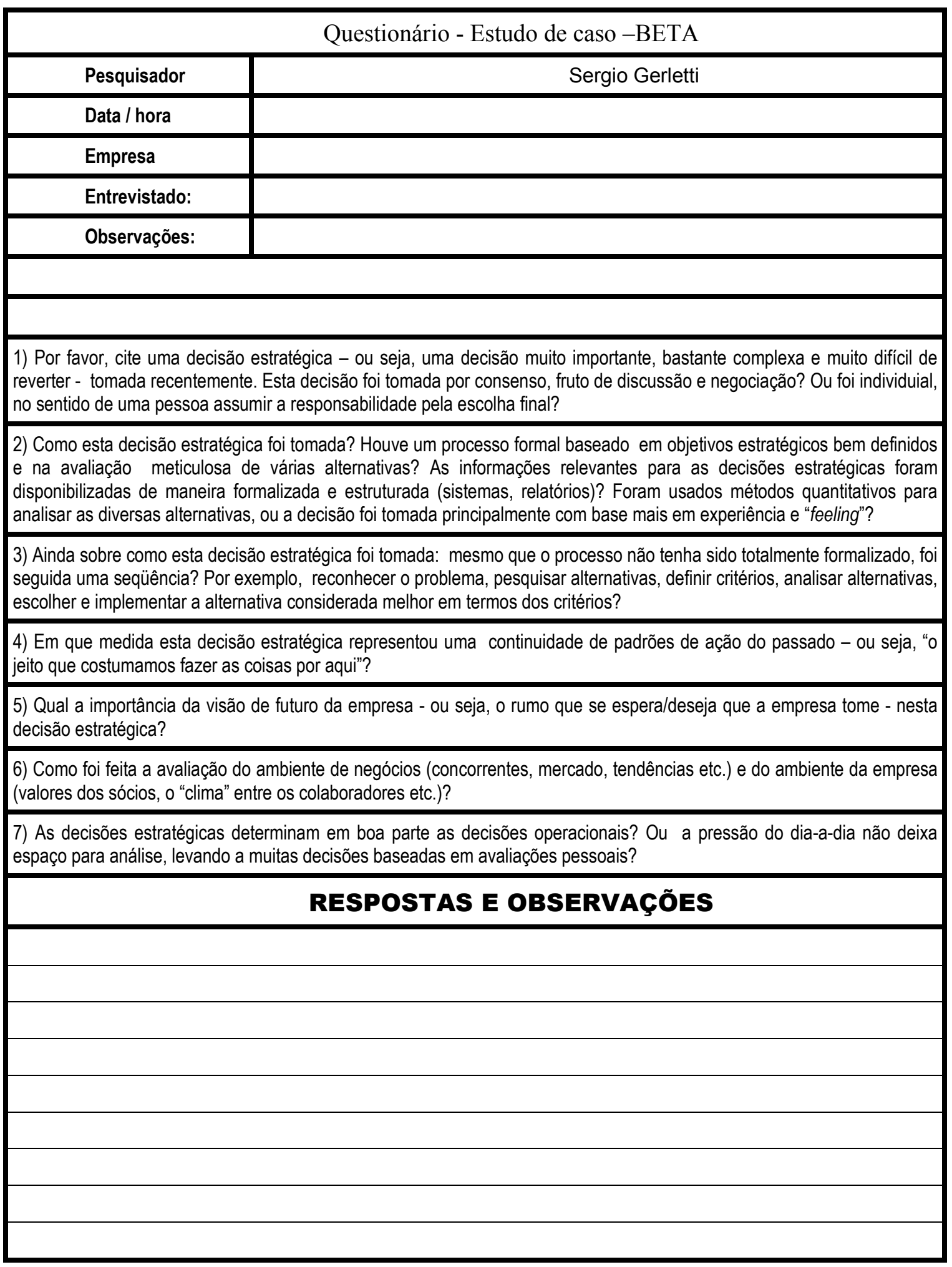

Este questionário se baseia no modelo utilizado por BARBERO (2008). 


\subsection{Anexo 5 - Método de Avaliação pelo Fluxo de Caixa Descontado}

Baseado em: DAMODARAN, Aswath. Avaliação de Investimentos - Ferramentas e Técnicas para a

Determinação de Qualquer Ativo. Rio: Qualitymark, 1997.

O método do Fluxo de Caixa Descontado - FCD consiste na determinação do valor da empresa com base na geração operacional futura de caixa acrescida de um valor residual ou de perpetuidade ao final do período projetado, trazidos a valor presente por uma taxa de desconto que reflete uma taxa de retorno média ponderada aos acionistas e credores da empresa, dado pela fórmula:

$$
\begin{aligned}
& \text { Valor da Empresa }=\sum_{t=1}^{\infty} \frac{\mathrm{CF} \text { da empresa }}{(1+W A C C)^{t}} \text {, onde: } \\
& \begin{array}{l}
\text { CF da empresa } \\
\text { é o Fluxo de caixa da empresa esperado no período t. } \\
\text { é o Custo Médio Ponderado de Capital. }
\end{array}
\end{aligned}
$$

É considerado como o valor justo da EMPRESA o valor presente de seus fluxos de caixa projetados, considerando como horizonte de planejamento 5 anos, após o que deve ser considerada uma perpetuidade da empresa (período de regime).

$\mathrm{Na}$ tabela 1, estão sintetizadas as análises financeiras dos demonstrativos enviados pela diretoria da EMPRESA, tanto Balanços Patrimoniais e Demonstrações dos Resultados dos Exercícios, como controles operacionais. 
Tabela 1 - Análise das Demonstrações Financeiras

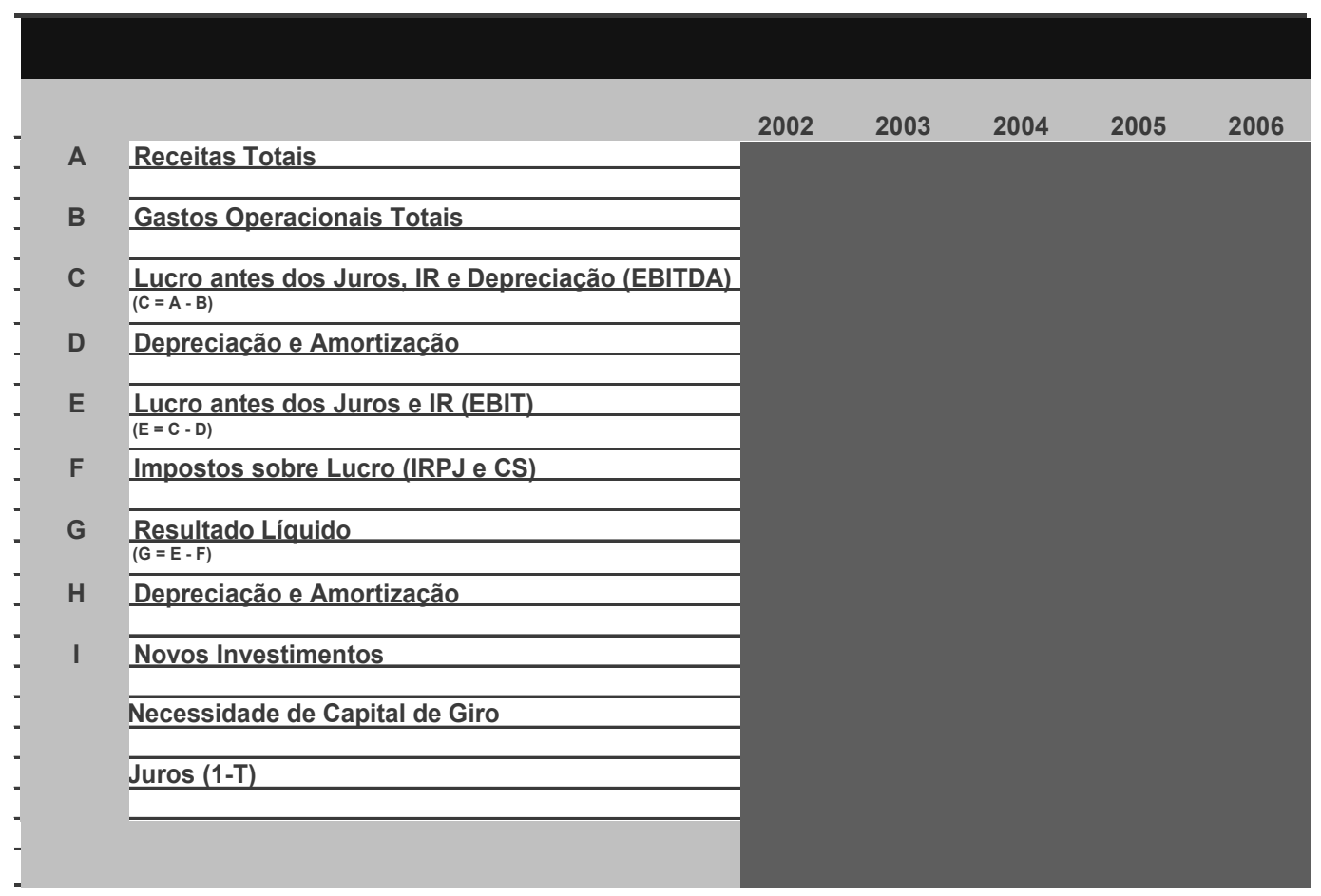

\section{Receitas Totais}

As Receitas Totais são as totalizações das vendas internas e externas, prestação de serviços e outras receitas especiais fornecidas pela EMPRESA. Estão no conceito de Receita Bruta, ou seja, incluem as vendas que foram devolvidas, porém excluem receitas financeiras e outras não operacionais como vendas de veículos e máquinas de propriedade da empresa.

\section{Gastos Operacionais Totais}

Nesta conta estão inclusas as Deduções (impostos sobre receita, devoluções e perdas), os Custos dos Produtos Vendidos (gastos com a produção como matéria-prima e mão de obra direta), as Despesas Administrativas (são os gastos relativos a Pró-labore, despesas financeiras deduzidas das receitas financeiras e impostos sobre imóvel e veículos), as Despesas com Vendas e as Correções Monetárias. 
Lucro antes dos Juros, IR e Depreciação

Este lucro, também chamado de Lucro Operacional ou EBITDA (Earnings Before Interest, Taxes, Depreciation and Amortization), reflete a geração de resultado influenciado pelas operações da empresa, excluídos gastos como Juros (redutor de caixa) e Depreciação (gerador de caixa, pois reduz pagamento com impostos sobre lucro). Ele é obtido pela subtração simples das Receitas Operacionais pelos Gastos Operacionais.

\section{Depreciação e Amortização}

Os gastos com depreciação e amortização são calculados com base nos ativos permanentes da empresa, estabelecendo uma relação entre valor do bem, vida útil e valor residual. Tem um caráter contábil, pois representa desembolso, e é utilizado para atenuar o pagamento de impostos sobre lucro, essencialmente, Imposto de Renda e Contribuição Social.

Lucro antes dos Juros e IR

É o resultado do Lucro antes dos Juros, Impostos e Depreciação deduzidos da Depreciação.

Impostos sobre Lucro (IRPJ e CS)

Valor conseguido junto à EMPRESA ou estimativas com base nos lucros auferidos.

Resultado Líquido

Resultado líquido é quanto foi gerado de lucro pelas operações da empresa deduzidos de impostos sobre lucros, juros e depreciações.

A tabela 2 sintetiza as análises do balanço patrimonial realizadas para possibilitar as projeções do fluxo de caixa livre da empresa. 
Tabela 2 - Análise dos Investimentos Realizados

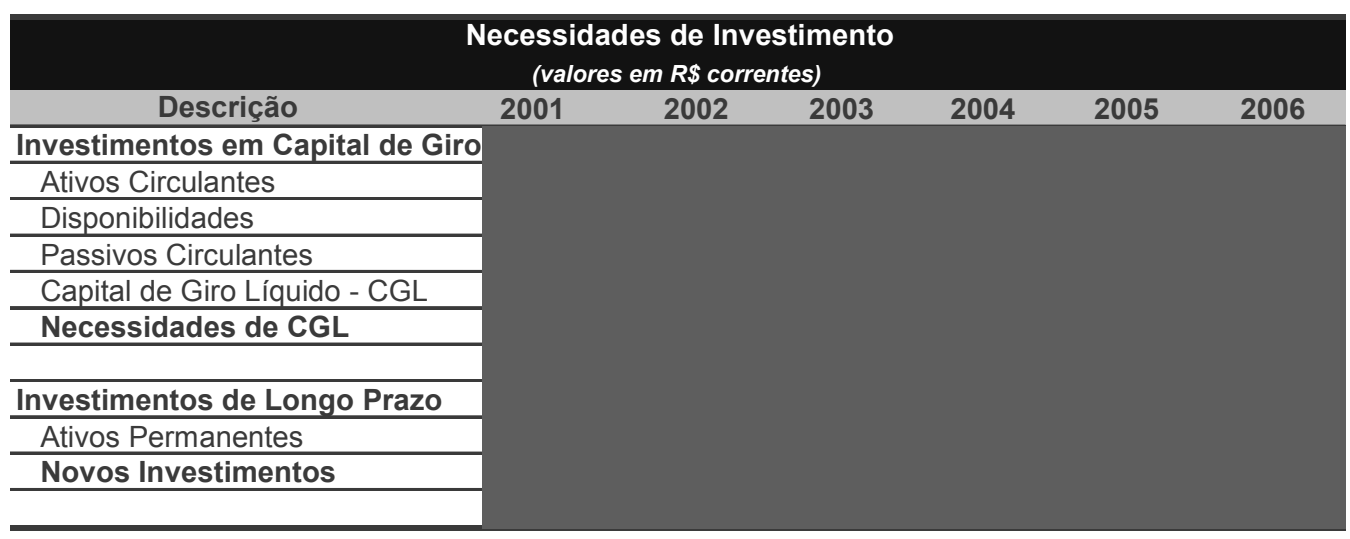

Investimentos em Capital de Giro

Capital de Giro é entendido como o investimento em ativos operacionais como caixa e estoques. Este investimento se faz necessário devido aos descolamentos entre recebimentos e pagamento, além da imprevisibilidade de demanda e custos. Por isso, capital de giro pode ser entendido também como os ativos circulantes. Esse investimento em ativos circulantes podem ter 2 fontes: Capital de Terceiros (principalmente as dívidas espontâneas de curto prazo, passivos circulantes) e Capital Próprio.

Deduzindo-se dos ativos circulantes as disponibilidades e os passivos circulantes, tem-se a parte do capital de giro financiado com capital próprio, chamado de capital de giro líquido CGL. Caso o capital de giro líquido aumente, serão necessários investimentos com capital próprio, consumindo assim fluxo de caixa.

Investimentos de Longo Prazo

Os investimentos de longo prazo são correspondem aos Ativos Permanentes e outros itens de baixa liquidez. 


\section{Cenário Referencial}

Consiste em um conjunto de indicadores econômicos, sintetizados na tabela 4. Para que a avalaição seja mais acurada, cada indicador deve ser estimado como um terno de valores (conservador; projetado; arrojado).A título de exemplo, são apresentadas abaixo projeções para o período $2007-9$.

Tabela 3 - Cenário Econômico Projetado.

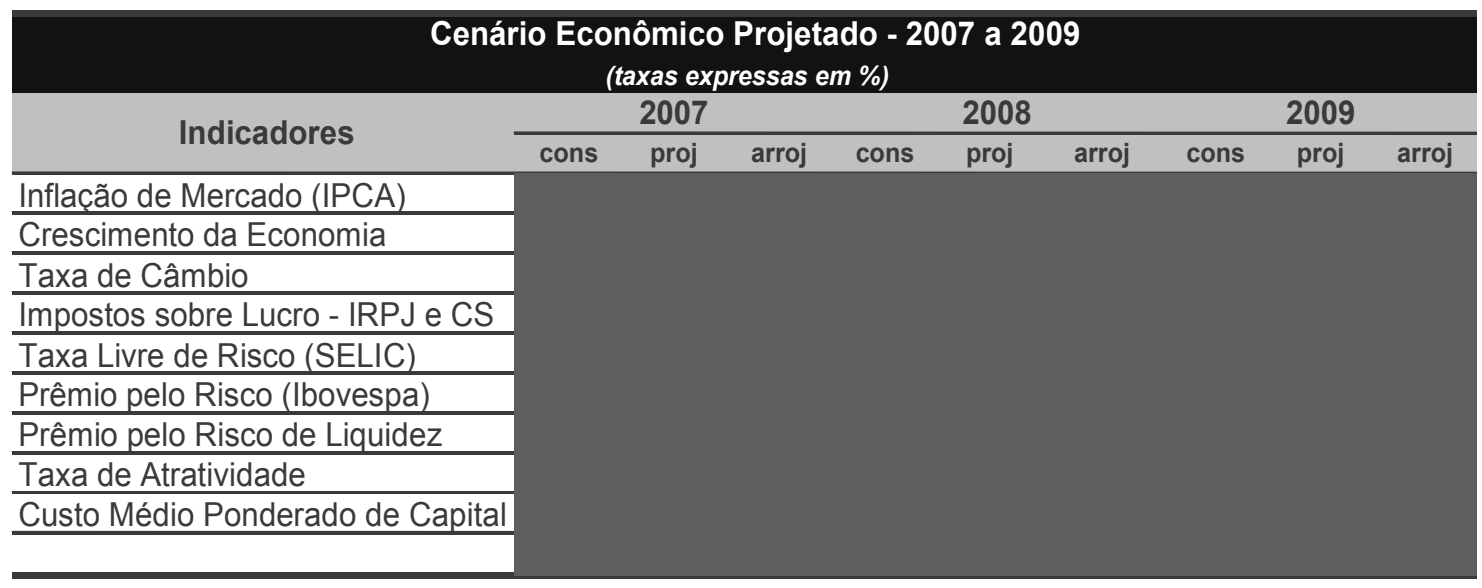

Inflação de Mercado (IPCA)

A expectativa do mercado financeiro para a inflação neste ano aponta para IPCA de 3,66\%. E a taxa de inflação medida pelo IPCA deverá manter-se consistente com a meta fixada pelo governo, cujo ponto central é de 4,5\% ao ano. Para 2011 e para o período em regime, esperase IPCA de 4\% ao ano, conforme projeções do Ministério do Planejamento ${ }^{4}$.

\section{Crescimento da Economia}

Segundo projeções do Ministério do Planejamento, a projeção de crescimento da economia brasileira para 2007 é de 4,20\%. Para os próximos anos, 2008 a 2011, a taxa de crescimento

\footnotetext{
${ }^{4}$ Fonte: www.planejamento.gov.br/orcamento/conteudo/noticias/noticias_2007/070412_nota_pldo.htm
} 
real anual do PIB é de 5,00\%. E para o período em regime, a projeção é de um crescimento do PIB de $4,50 \%{ }^{5}$.

\section{Taxa Livre de Risco (SELIC)}

A taxa Selic é a taxa de financiamento no mercado interbancário para operações que possuem lastro em títulos públicos federais, listados e negociados no Sistema Especial de Liquidação e Custódia, ou Selic. A taxa Selic reflete o custo do dinheiro para empréstimos bancários com base na remuneração dos títulos públicos e serve como referência (taxa livre de risco) para as demais taxas de juros da economia. As projeções seguiram as metas previstas pelo Banco Central.

\section{Prêmio pelo Risco (Ibovespa)}

O Prêmio pelo Risco foi dimensionado utilizando como variável proxi o rendimento do IBOVESPA dos últimos anos e suas projeções realizadas por diversos órgãos como BOVESPA, Revista Exame e Economática.

Esse parâmetro foi utilizado considerando que reflete os ganhos que um investidor teria caso investisse em outras empresas, ou seja, é a percepção de quanto um investidor teria de prêmio por assumir mais riscos do que se tivesse investido em títulos livre de risco.

\section{Prêmio pelo Risco de Liquidez}

Uma empresa de capital fechado possui mais risco do que uma de capital aberto, portanto é arbitrada uma taxa que remunera esse risco assumido pelo investidor. Esses riscos podem ser atribuídos, principalmente, a falta de liquidez que possui essa tipologia de empresa.

5 Fonte: www.planejamento.gov.br/orcamento/conteudo/noticias/noticias_2007/070412_nota_pldo.htm 
Taxa de Atratividade

A taxa de atratividade é a soma algébrica do Prêmio Pelo Risco de Mercado com o Prêmio pelo Risco de Liquidez e reflete o risco do capital próprio investido na empresa.

Custo Médio Ponderado de Capital - CMPC

CMPC é a ponderação entre os custos das mais diversas fontes de financiamento de uma empresa e é dado pela equação:

$C M P C=w_{c t} \times k_{c t}+w_{c p} \times k_{c p}$, onde:

$w_{c t} \quad$ é a proporção em \% da participação de capital de terceiros

$k_{c t} \quad$ é o custo do capital de terceiros em taxa anual

$w_{c p} \quad$ é a proporção em \% da participação de capital próprio

$k_{c p} \quad$ é o custo do capital próprio em taxa anual

A Elaboração do Fluxo de Caixa

O ponto de partida para a elaboração do fluxo de caixa é seu lucro operacional após IR, conforme apurado anteriormente. Nos itens a seguir, são apresentados alguns ajustes necessários para transformar esse lucro no FCLE:

SOMAR A DEPRECIAÇÃO E AS AMORTIZAÇÕES DE ATIVOS DIFERIDOS. Como não são saídas de caixa, a depreciação e as amortizações de diferidos não deveriam ter sido subtraídas na projeção do fluxo de caixa. Por isso, são trazidas de volta. O efeito líquido da depreciação e das amortizações de intangíveis é apenas a redução dos tributos sobre a renda.

DESCONTAR O INVESTIMENTO EM ATIVOS PERMANENTES. A principal conta é a de imobilizados, que inclui, entre outras coisas, imóveis, veículos, máquinas e equipamentos e 
instalações. Esses investimentos devem ser considerados na medida em que são necessários para a capacidade de geração do caixa operacional projetado. Eles não devem ser superestimados, nem subavaliados.

DESCONTAR O INVESTIMENTO EM CAPITAL DE GIRO. O suprimento das necessidades iniciais de estoques e contas a receber também é um investimento. Ele é parcial e espontaneamente financiado pelas contas a pagar de natureza operacional (fornecedores, salários, tributos). À medida que a empresa cresce, novos investimentos podem ser necessários para ampliar seu capital de giro.

FLUXO DE CAIXA LIVRE PARA A EMPRESA (FCLE). É obtido a partir do lucro operacional líquido do imposto de renda (Noplat), mais depreciação a amortizações, menos investimentos em ativos permanentes e em capital de giro.

Tabela 4 - Projeção das Receitas.

\begin{tabular}{|c|c|c|c|c|c|c|c|c|c|c|c|c|c|c|c|c|c|c|}
\hline \multicolumn{19}{|c|}{$\begin{array}{l}\text { Expectativa de Receitas - } 2007 \text { a } 2011 \text { e Regime } \\
\text { (R\$ mil de dez/06) }\end{array}$} \\
\hline \multirow{2}{*}{ Unidades de Negócio } & \multicolumn{3}{|c|}{2007} & \multicolumn{3}{|c|}{2008} & \multicolumn{3}{|c|}{2009} & \multicolumn{3}{|c|}{2010} & \multicolumn{3}{|c|}{2011} & \multicolumn{3}{|c|}{ REGIME } \\
\hline & cons & proj & arroj & cons & proj & arroj & cons & proj & arroj & cons & proj & arroj & cons & proj & arroj & cons & proj & arroj \\
\hline Mercado 1: & & & & & & & & & & & & & & & & & & \\
\hline Mercado 2: & & & & & & & & & & & & & & & & & & \\
\hline Mercado 3: & & & & & & & & & & & & & & & & & & \\
\hline Totais & & & & & & & & & & & & & & & & & & \\
\hline Crescimento Projetado & & & & & & & & & & & & & & & & & & \\
\hline
\end{tabular}

Tabela 5 - Projeção dos Gastos Operacionais Totais.

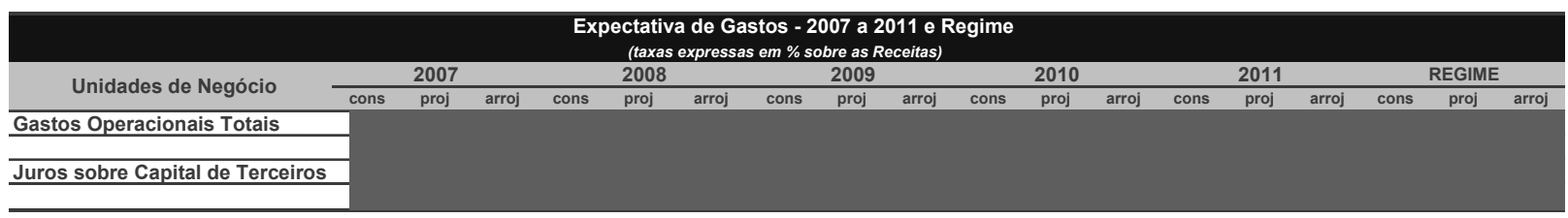


Tabela 6 - Projeção dos Investimentos e Endividaentos.

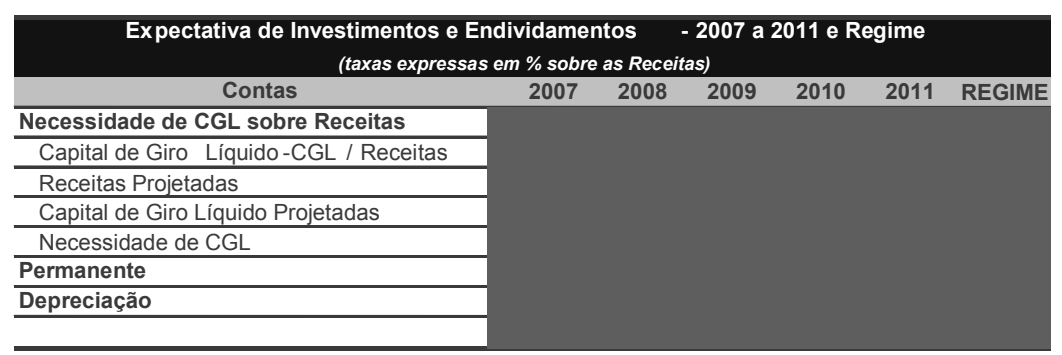

Com base nas projeções apresentadas, o valor de negociação para a EMPRESA é:

Tabela 7 - Fluxo de Caixa Descontado da EMPRESA.

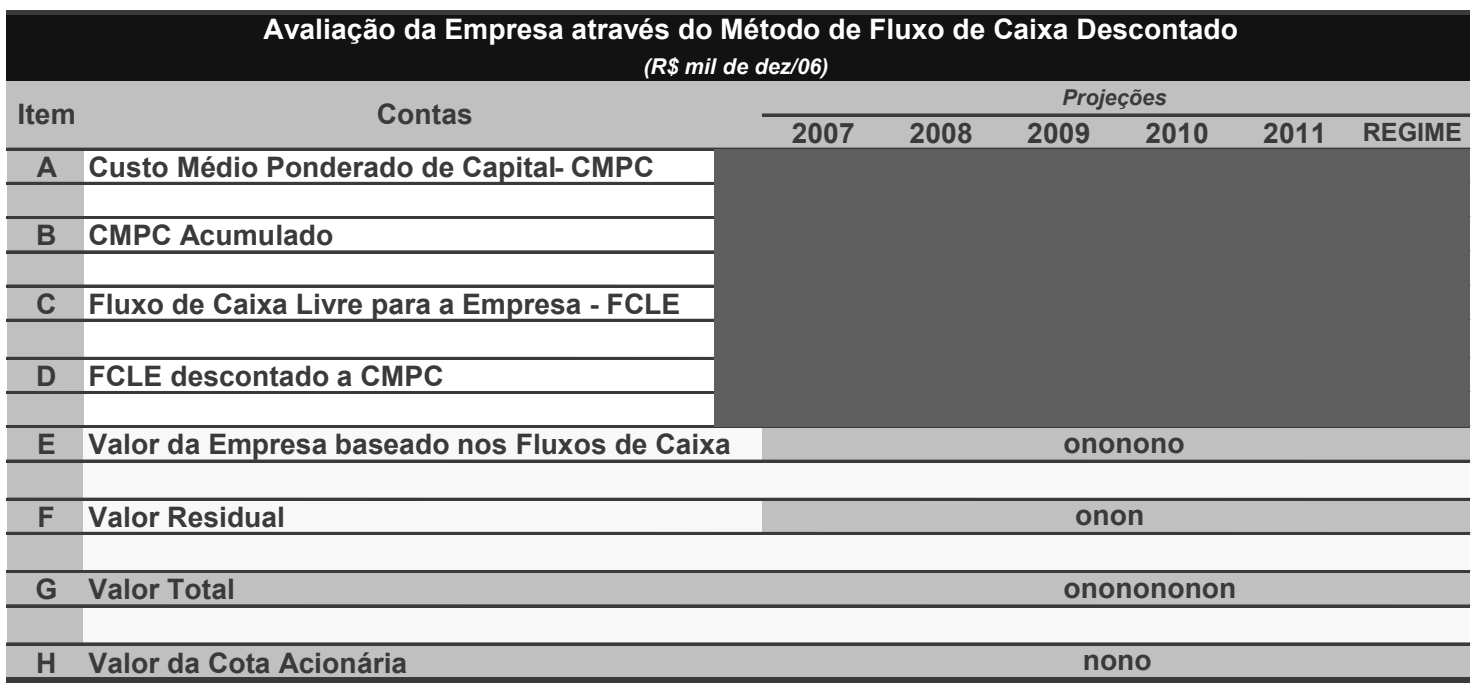

\section{Avaliação dos Riscos do Negócio}

Conforme visto nas tabelas dos cenários utilizados, além do valor projetado, é assumido como possível qualquer valor encontrado entre uma referência conservadora e arrojada. O valor da empresa é baseado no cenário projetado, porém é sabido que esses valores podem variar para cima ou para baixo a depender das variáveis macroeconômicas e setoriais. Para uma melhor tomada de decisão dos investidores, esta variabilidade deve ser analisada. No exemplo sintetizadosna Tabela 9 (valores fictícios), foramgerados 100 cenários possíveis utilizando-se a técnica de simulação de Monte Carlo. 
Tabela 8 - Análise dos Riscos das Projeções.

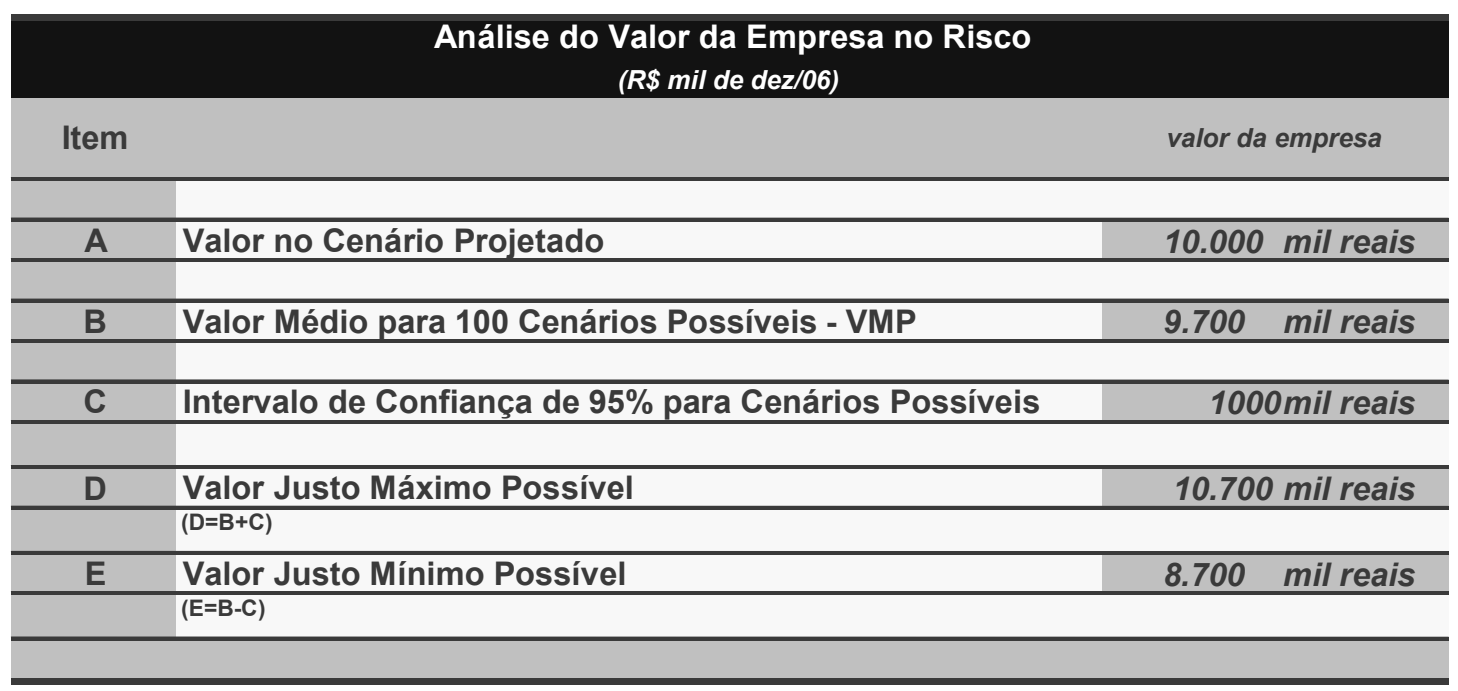

Com isso, pode-se afirmar que dentre os cenários possíveis projetados, com $95 \%$ de confiança, a média de seus valores vão variar entre 8.700 e 10.700 mil reais, (exemplo com valores fictícios), podendo esta banda nortear a melhor negociação. 